\title{
LA-14004-MS
}

Approved for public release

\section{Characterization Well R-7 \\ Geochemistry Report}

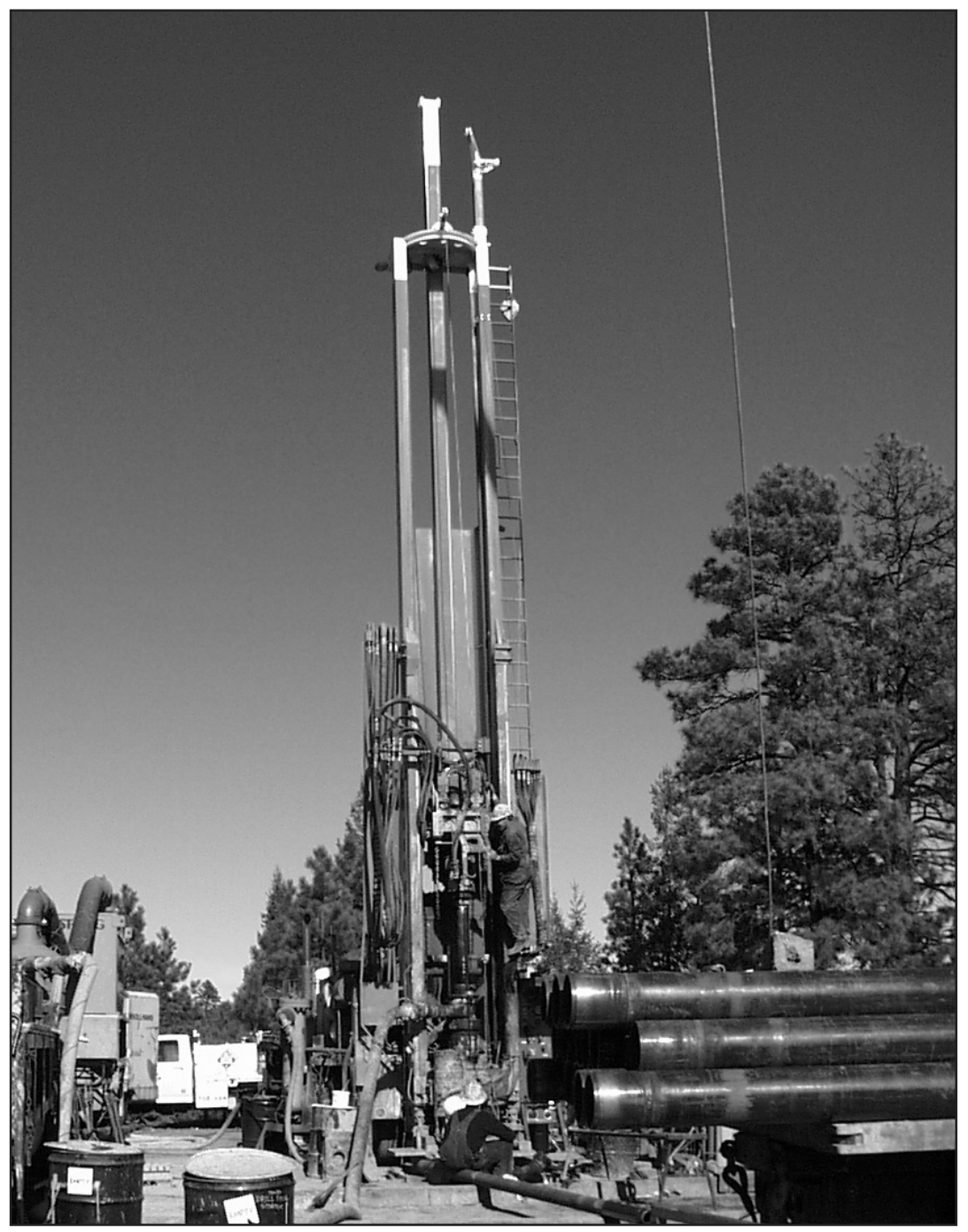


Produced by the Risk Reduction and Environmental Stewardship Division

Cover photo shows a modified Foremost DR-24 dual-rotary drill rig. The DR-24 is one of several drill-rig types being used for drilling, well installation, and well development in support of the Los Alamos National Laboratory Hydrogeologic Workplan. The Hydrogeologic Workplan is jointly funded by the Environmental Restoration Project and Defense Programs to characterize groundwater flow beneath the 43-square-mile area of the Laboratory and to assess the impact of Laboratory activities on groundwater quality. The centerpiece of the Hydrogeologic Workplan is the installation of up to 32 deep wells in the regional aquifer.

An Affirmative Action/Equal Opportunity Employer

This report was prepared as an account of work sponsored by an agency of the United States Government. Neither The Regents of the University of California, the United States

Government nor any agency thereof, nor any of their employees, makes any warranty, express or implied, or assumes any legal liability or responsibility for the accuracy, completeness, or usefulness of any information, apparatus, product, or process disclosed, or represents that its use would not infringe privately owned rights. Reference herein to any specific commercial product, process, or service by trade name, trademark, manufacturer, or otherwise, does not necessarily constitute or imply its endorsement, recommendation, or favoring by The Regents of the University of California, the United States Government, or any agency thereof. The views and opinions of authors expressed herein do not necessarily state or reflect those of The Regents of the University of California, the United States Government, or any agency thereof. Los Alamos National Laboratory strongly supports academic freedom and a researcher's right to publish; as an institution, however, the Laboratory does not endorse the viewpoint of a publication or guarantee its technical correctness. 
Characterization Well R-7

Geochemistry Report

Patrick Longmire

Fraser Goff

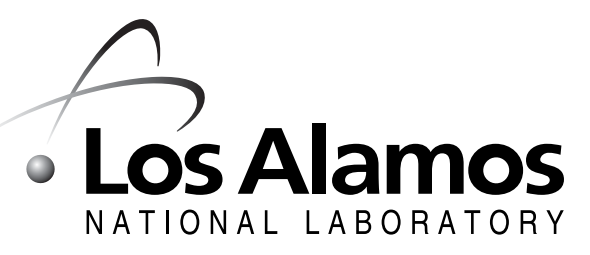

Los Alamos NM 87545 

TABLE OF CONTENTS

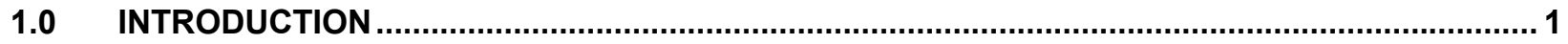

2.0 DRILLING METHODS AND WELL DESIGN

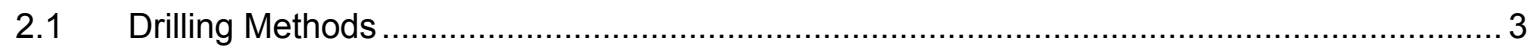

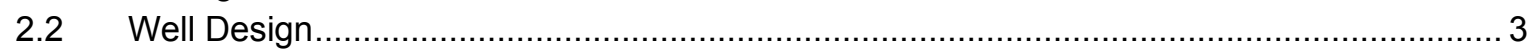

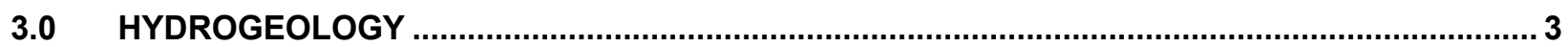

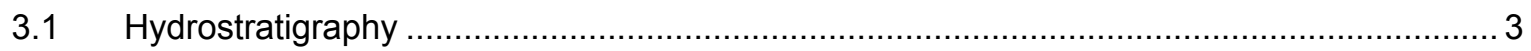

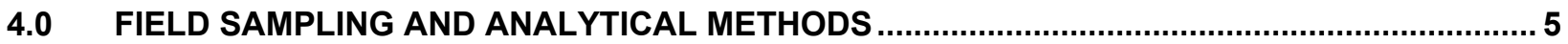

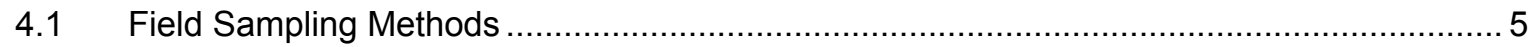

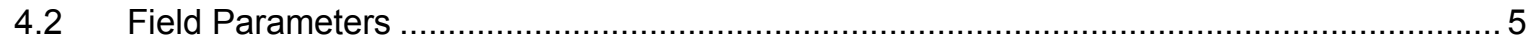

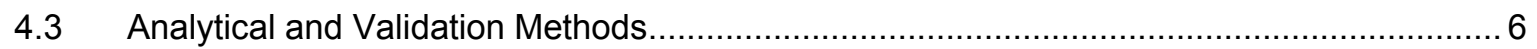

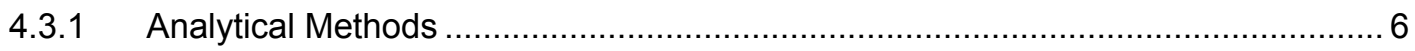

4.3.2 Validation Methods ................................................................................... 7

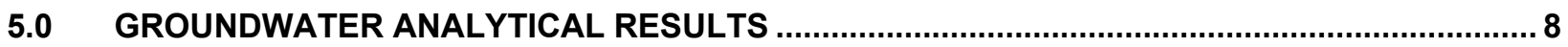

5.1 Major lons, Metals, Radionuclides, Organic Compounds, and Stable Isotopes ................. 8

5.2 Comparison to Wells R-7, R-9, R-9i, R-12, R-15, R-19, and R-22 …............................ 22

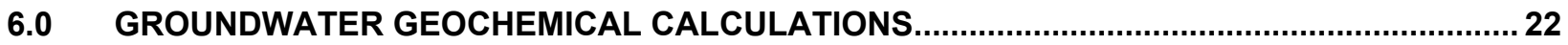

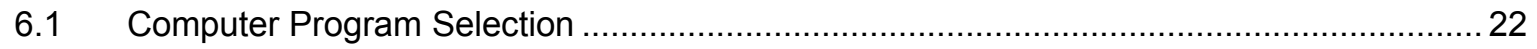

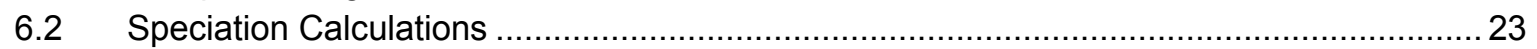

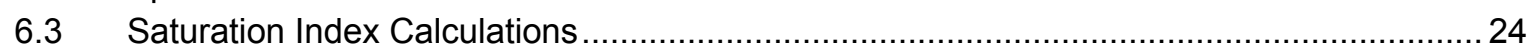

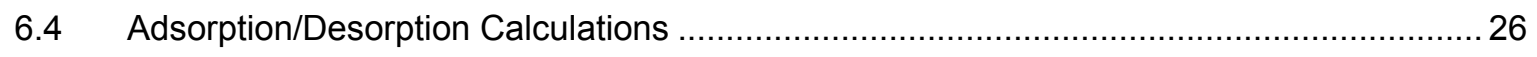

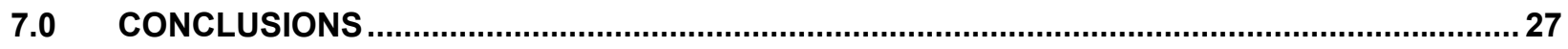

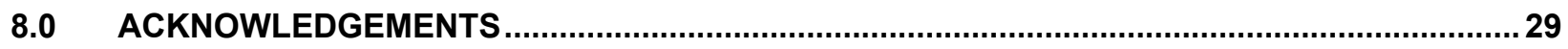

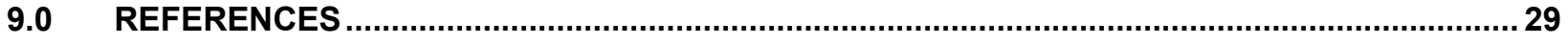

Appendixes

Appendix A Groundwater Analytical Results

Appendix B Geochemical Calculations 


\section{List of Figures}

Figure 1.0-1. Locations of well R-7, selected water supply wells, test wells, and springs near the Rio Grande, and generalized water-level contours for the regional aquifer ..................... 2

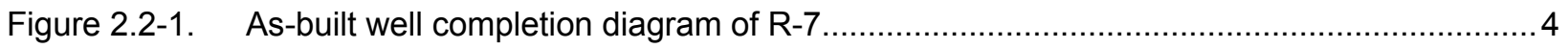

Figure 5.1-1. Major ion chemistry for well R-7 (perched zone, $378.0 \mathrm{ft}$ ), screen \#1 ....................... 13

Figure 5.1-2. Major ion chemistry for well R-7 (regional aquifer, $915.0 \mathrm{ft}$ ), screen \#3 ....................... 13

Figure 5.1-3. Concentrations of dissolved iron, manganese, ammonium, dissolved organic carbon, total Kjeldahl nitrogen, and sulfate versus time at well R-7, screen \#3 (915.0 ft)............ 14

Figure 5.1-4. Log molality iron versus log molality nickel for well R-7 (915.0 ft), screen \#3 ................ 17

Figure 5.1-5. Average stable isotope results for wells R-5, R-7, R-9i, R-12, R-15, R-19, R-22, R-25, White Rock Canyon Springs, regional aquifer, DP Spring, Sierra de los Valles, Valles ring fracture zone, and "confined aquifer". 19

Figure 6.3-1. Results of saturation index calculations using MINTEQA2 for well R-7 (perched zone, $378.0 \mathrm{ft}$ )

Figure 6.3-2. Results of saturation index calculations using MINTEQA2 for well R-7 (regional aquifer, $915.0 \mathrm{ft}$ )

\section{List of Tables}

Table 4.2-1a Field-Measured Parameters for Groundwater Samples Collected at Well R-7,

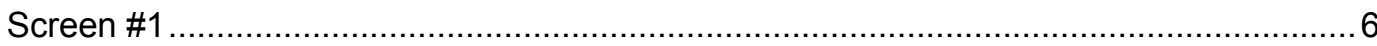

Table 4.2-1b Field-Measured Parameters for Groundwater Samples Collected at Well R-7,

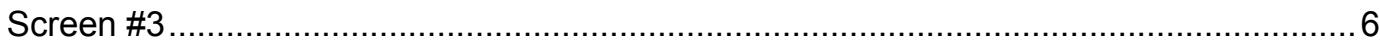

Table 5.1-1 Hydrochemistry of Selected Analytes for Well R-7, Screen \#1 …................................... 9

Table 5.1-2 Hydrochemistry of Selected Analytes for Well R-7, Screen \#3 ....................................... 11

Table 6.2-1 Results of Speciation Calculations Using MINTEQA2 for Well R-7 (screen \#3, $915.0 \mathrm{ft}$ ), Upper Los Alamos Canyon

Table 6.4-1 Results of Adsorption Calculations Using MINTEQA2 for Well R-7 Sampled on May 31, 2001 (Screen \#3, Regional Aquifer), Upper Los Alamos Canyon 


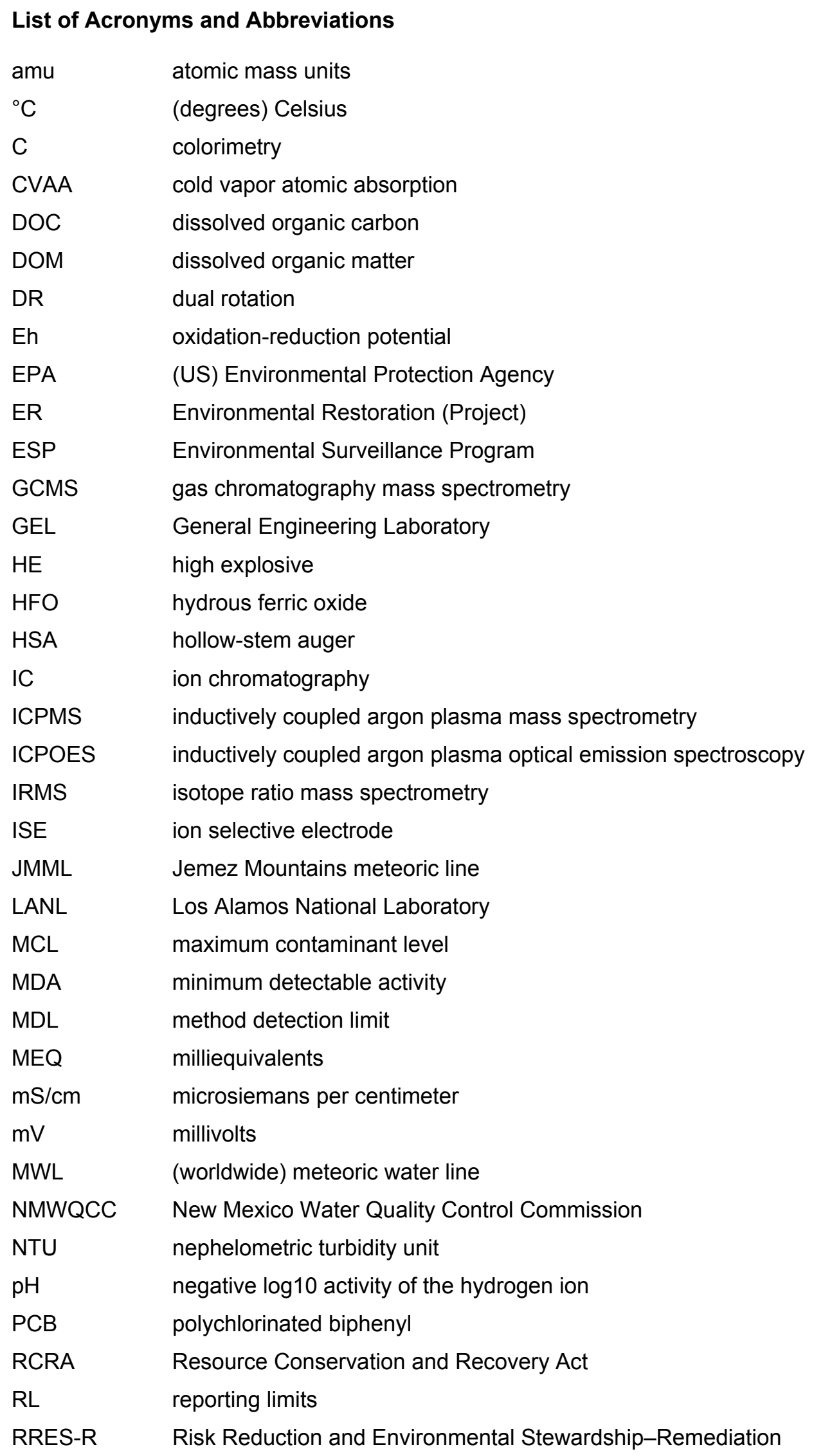


SI

SOP

SVOC

TA

TDS

TKN

TOC

VOC saturation index

standard operating procedure

semivolatile organic compound

technical area

total dissolved solids

total Kjeldahl nitrogen

total organic carbon

volatile organic compound

\section{Metric to US Customary Unit Conversions}

\begin{tabular}{|l|c|l|}
\hline \multicolumn{1}{|c|}{ Multiply SI (Metric) Unit } & by & To Obtain US Customary Unit \\
\hline kilometers $(\mathrm{km})$ & 0.622 & miles $(\mathrm{mi})$ \\
\hline kilometers $(\mathrm{km})$ & 3281 & feet $(\mathrm{ft})$ \\
\hline meters $(\mathrm{m})$ & 3.281 & feet $(\mathrm{ft})$ \\
\hline meters $(\mathrm{m})$ & 39.37 & inches $(\mathrm{in})$. \\
\hline centimeters $(\mathrm{cm})$ & 0.03281 & feet $(\mathrm{ft})$ \\
\hline centimeters $(\mathrm{cm})$ & 0.394 & inches $(\mathrm{in})$. \\
\hline millimeters $(\mathrm{mm})$ & 0.0394 & inches $(\mathrm{in})$. \\
\hline micrometers or microns $(\mu \mathrm{m})$ & 0.0000394 & inches (in.) \\
\hline square kilometers $\left(\mathrm{km}{ }^{2}\right)$ & 0.3861 & square miles $\left(\mathrm{mi}^{2}\right)$ \\
\hline hectares $($ ha) & 2.5 & acres \\
\hline square meters $\left(\mathrm{m}^{2}\right)$ & 10.764 & square feet $\left(\mathrm{ft}^{2}\right)$ \\
\hline cubic meters $\left(\mathrm{m}^{3}\right)$ & 35.31 & cubic feet $\left(\mathrm{ft}^{3}\right)$ \\
\hline kilograms $(\mathrm{kg})$ & 2.2046 & pounds $(\mathrm{lb})$ \\
\hline grams $(\mathrm{g})$ & 0.0353 & ounces $(\mathrm{oz})$ \\
\hline grams per cubic centimeter $\left(\mathrm{g} / \mathrm{cm}^{3}\right)$ & 62.422 & pounds per cubic foot $\left(\mathrm{lb} / \mathrm{ft}^{3}\right)$ \\
\hline milligrams per kilogram $(\mathrm{mg} / \mathrm{kg})$ & 1 & parts per million $(\mathrm{ppm})$ \\
\hline micrograms per gram $(\mu \mathrm{gg} / \mathrm{g})$ & 1 & parts per million $(\mathrm{ppm})$ \\
\hline liters $(\mathrm{L})$ & 0.26 & gallons $(\mathrm{gal})$. \\
\hline milligrams per liter $(\mathrm{mg} / \mathrm{L})$ & 1 & parts per million $(\mathrm{ppm})$ \\
\hline degrees Celsius $\left({ }^{\circ} \mathrm{C}\right)$ & $9 / 5+32$ & degrees Fahrenheit $\left({ }^{\circ} \mathrm{F}\right)$ \\
\hline
\end{tabular}




\title{
CHARACTERIZATION WELL R-7 GEOCHEMISTRY REPORT
}

\section{by}

\author{
Patrick Longmire and Fraser Goff
}

\begin{abstract}
This report provides analytical results for groundwater collected during four characterization-sampling rounds conducted at well R-7 from May 2001 through February 2002. Characterization well R-7 was sampled from May 30 and 31, 2001; August 8 and 9, 2001; November 19 and 26, 2001; and February 19 and 20, 2002. The goal of the characterization efforts was to assess the hydrochemistry and to determine whether contaminants are present in the regional aquifer in the vicinity of the well. This report also presents a geochemical evaluation of the analytical results for the well.

Characterization well R-7 is located in upper Los Alamos Canyon, about one mile west of its confluence with DP Canyon within Los Alamos National Laboratory (LANL or the Laboratory). This location was selected to provide a well east of Technical Area (TA)-2 and south of TA-21, where Laboratory effluent has been released, including radionuclides and inorganic chemicals. The results of the well R-7 study showed that the groundwater has not been impacted by Laboratory discharges from TA-2 and TA-21. The well permits characterization of the occurrence and quality of water in both perched groundwater (screen \#1) and the regional aquifer (screen \#3). Screen \#2, set in the vadose zone, was dry at well completion.
\end{abstract}

Well R-7 was completed on March 9, 2001, with three screens (363.2 to $379.2 \mathrm{ft}, 730.4$ to $746.4 \mathrm{ft}$, and 895.5 to $937.4 \mathrm{ft}$ ). Screen \#2 was dry during characterization sampling. A Westbay ${ }^{\circledR}$ Instrument, Inc., MP55 $®$ monitoring system was set within clastic sedimentary rocks of the Puye Formation (screens \#1, $\# 2$, and \#3). Four rounds of groundwater characterization samples, collected from a perched zone and the regional aquifer from depths of $378.0 \mathrm{ft}$ (screen \#1) and $915.0 \mathrm{ft}$ (screen \#3), were analyzed for radionuclides, metals and trace elements, major ions, high explosive compounds, total organic carbon, dissolved organic carbon, organic compounds, and stable isotopes $(\mathrm{H}, \mathrm{N}$, and $\mathrm{O})$.

Activities of tritium in the perched zone (screen \#1) and the regional aquifer (screen \#3) averaged 2.98 and $1.76 \mathrm{pCi} / \mathrm{L}$, respectively. This finding suggests that a major component of the groundwater predates the beginning of atmospheric nuclear testing (based on the cosmogenic baseline of tritium of $19 \mathrm{pCi} / \mathrm{L}$ prior to testing). Well R-7 groundwater contains a minor component of pre-nuclear testing tritium that has mixed with native groundwater. Given its half-life of 12.43 years, the majority of natural tritium has decayed to helium. The detection of tritium in groundwater samples indicates that well R-7 has experienced minor recharge within the past 35 years. Furthermore, the levels of tritium activity indicate that well R-7 has not been impacted by Laboratory discharges.

Stable isotope ratios for $\delta \mathrm{D}$ and $\delta^{18} \mathrm{O}$ imply that the sampled groundwater at well R-7 was derived from a local meteoric source consisting of precipitation and surface water within the Sierra de los Valles. Results of $\delta^{15} \mathrm{~N}_{\mathrm{AIR}}-\mathrm{NO}_{3}$ analyses suggest that some fractionation of natural nitrate plus nitrite (as $\mathrm{N}$ ) has occurred $(+0.9$ to $+3.3 \%$ ) , implying that biochemical reactions are important in controlling the distribution of nitrogen at well R-7.

Americium-241, cesium-137, plutonium-238, plutonium-239,240, strontium-90, technetium-99, and uranium-235 were not detected in the groundwater samples collected from well R-7. Activities of 
uranium-234 and uranium-238 were generally detected only at concentrations less than $0.1 \mathrm{pCi} / \mathrm{L}$, similar to activities of isotopic uranium measured in supply wells Otowi-1, Otowi-4, Pajarito Mesa 1 through 5, and the Guaje well field according to an environmental surveillance conducted at Los Alamos in 2000. Gross alpha and gross beta activities were less than $4 \mathrm{pCi} / \mathrm{L}$ in groundwater samples collected from screens \#1 and \#3. Gross gamma activities ranging between 122 and $181 \mathrm{pCi} / \mathrm{L}$ in several groundwater samples were attributed to isotopes within the natural uranium-238, uranium-235, and thorium-232 decay chains.

Groundwater within both the perched zone and regional aquifer at well R-7 were characterized as calcium-sodium-bicarbonate ionic compositions within the Puye Formation. Calculated total dissolved solids in the perched zone (screen \#1) ranged between 121 and $163 \mathrm{mg} / \mathrm{L}$; in the regional aquifer (screen \#3) they ranged between 215 and $234 \mathrm{mg} / \mathrm{L}$.

Average detectable concentrations of dissolved chloride, fluoride, nitrate plus nitrite (as $\mathrm{N}$ ), and sulfate were $1.54,0.15,0.19$, and $2.37 \mathrm{mg} / \mathrm{L}$, respectively, within the perched zone at a depth of $378.0 \mathrm{ft}$. Average detectable concentrations of dissolved chloride, fluoride, nitrate plus nitrite (as $\mathrm{N}$ ), and sulfate were $2.06,0.36,0.05$ (single detection), and 0.41 (single detection) $\mathrm{mg} / \mathrm{L}$, respectively, within the regional aquifer at a depth of $915.0 \mathrm{ft}$.

Analytical results for well R-7 show that solute concentrations within the regional aquifer, excluding manganese (US Environmental Protection Agency [EPA] secondary standard for drinking water of $0.05 \mathrm{mg} / \mathrm{L}$ ), nickel (EPA primary standard for drinking water of $0.1 \mathrm{mg} / \mathrm{L}$ ), and iron (EPA secondary standard for drinking water of $0.3 \mathrm{mg} / \mathrm{L}$ ), were below EPA and New Mexico Environmental Department (New Mexico Water Quality Control Commission) standards. During the first and second sampling rounds, maximum concentrations of dissolved iron and manganese observed in the regional aquifer were 17.0 and $3.4 \mathrm{mg} / \mathrm{L}$, respectively, in screen \#3. Elevated concentrations of natural iron, nickel, and manganese were the result of reductive dissolution of ferric (oxy)hydroxide and manganese dioxide in the presence of residual drilling fluid at well $\mathrm{R}-7$. Concentrations of natural iron, nickel, and manganese generally decreased during characterization sampling, suggesting that residual drilling fluids are breaking down or dissociating and the well is re-equilibrating with groundwater in the regional aquifer. Reducing conditions with respect to nitrogen (ammonium and total Kjeldahl nitrogen), sulfur, iron, and manganese dominate in the upper portion of the regional aquifer (screen \#3) because of residual drilling fluids. Well R-7 is also reequilibrating with groundwater as residual drilling fluid oxidizes to inorganic carbon (bicarbonate).

Oxidizing conditions should be re-established when residual drilling fluid is removed from well R-7.

The mineralogy of the solid samples and the hydrochemical data indicate that the regional aquifer was oxidizing prior to the drilling of well R-7. Geochemical calculations using the computer program MINTEQA2 show that the well is re-equilibrating with groundwater that has been impacted by residual drilling fluid, resulting in desorption of nickel from hydrous ferric oxide. Uranium(IV) is calculated to be stable as $\mathrm{U}(\mathrm{OH})_{4}{ }^{0}$ under induced reducing conditions characterized by elevated total organic carbon and dissolved organic carbon and the absence of sulfate in the regional aquifer at this well (screen \#3). As oxidizing conditions re-establish during breakdown of drilling fluids, uranyl hydroxo and uranyl carbonato (anionic) complexes are calculated to be stable in the regional aquifer. Groundwater in the perched zone (screen \#1) is calculated to be undersaturated with respect to $\mathrm{CaCO}_{3}$ (calcite), $\mathrm{BaSO}_{4}, \mathrm{MnCO}_{3}, \mathrm{SrCO}_{3}$, and amorphous silica precipitate. This groundwater is calculated to be oversaturated with respect to silica gel. Groundwater in the regional aquifer (screen \#3) is calculated to be undersaturated with respect to silica precipitate, $\mathrm{CaCO}_{3}, \mathrm{BaSO}_{4}$, and $\mathrm{SrCO}_{3}$, and oversaturated with respect to silica gel, $\mathrm{FeCO}_{3}$, and $\mathrm{USiO}_{4}$. Groundwater samples collected from screen \#3 show variable saturation with $\mathrm{MnCO}_{3}$. 


\subsection{INTRODUCTION}

This report provides analytical results for four groundwater-sampling rounds conducted at characterization well R-7. The goal of the characterization efforts was to assess the hydrochemistry and to determine if contaminants from Technical Area (TA)-2 and TA-21 of the Los Alamos National Laboratory (LANL or the Laboratory) are present in the regional aquifer in the vicinity of the well. Figure 1.0-1 shows the well's location in the narrow upper part of Los Alamos Canyon, between the inactive Omega West reactor and the mouth of DP Canyon. Well R-7 is in an excellent location to characterize the hydrology and groundwater chemistry in both perched groundwater and the regional aquifer near sites of known Laboratory effluent release, including radionuclides and inorganic chemicals (Stone et al. 2002, 72717).

The Risk Reduction and Environmental Stewardship-Remediation (RRES-R) Program (formerly the Environmental Restoration [ER] Project) installed well R-7 as part of groundwater investigations to satisfy requirements of the "Hydrogeologic Workplan" (LANL 1998, 59599) and to support the Laboratory's "Groundwater Protection Management Program Plan" (LANL 1996, 70215). Well R-7 was designed primarily to provide geochemical or water quality and hydrogeologic data for the regional aquifer within the Puye Formation.

This report also presents a geochemical evaluation of the analytical results for well R-7 and provides hydrogeochemical interpretations using analytical results for groundwater samples collected at the well. Discussion of other hydrogeochemical data collected within the east-central portion of the Laboratory, however, is deferred until they can be evaluated in the context of sitewide information collected from other RRES and Hydrogeologic Workplan characterization wells (R-8A, R-9, and R-9i). Once all deep groundwater investigations in the east-central portion of the Laboratory are completed, geochemical and hydrogeologic conceptual models for the Los Alamos Canyon watershed may be included in a groundwater risk analysis. These models will include an evaluation of potential contaminant transport pathways.

Well R-7 was completed on March 9, 2001, with three screens (363.2 to $379.2 \mathrm{ft}, 730.4$ to $746.4 \mathrm{ft}$, and 895.5 to $937.4 \mathrm{ft}$ ). Screen \#2 was dry during characterization sampling. Four rounds of groundwater characterization samples, collected from a perched zone and the regional aquifer from depths of $378.0 \mathrm{ft}$ (screen \#1) and $915.0 \mathrm{ft}$ (screen \#3), were chemically characterized for radionuclides, metals and trace elements, major ions, high-explosive (HE) compounds, total organic carbon, dissolved organic carbon, organic compounds, and stable isotopes $(\mathrm{H}, \mathrm{N}$, and $\mathrm{O})$.

Although well R-7 is primarily a characterization well, its design and construction also meet the requirements of a Resource Conservation and Recovery Act (RCRA)-compliant monitoring well as described in the US Environmental Protection Agency (EPA) document "RCRA Groundwater Monitoring: Draft Technical Guidance," November 1992, EPA 530-R-93-001. Incorporation of this well into a Laboratory-wide groundwater-monitoring program will be considered, and more specifically evaluated (e.g., sampling frequency, analytes, etc.), when the results of the well R-7 characterization activities are comprehensively evaluated in conjunction with other groundwater investigations in the "Hydrogeologic Workplan" (LANL 1998, 59599). 

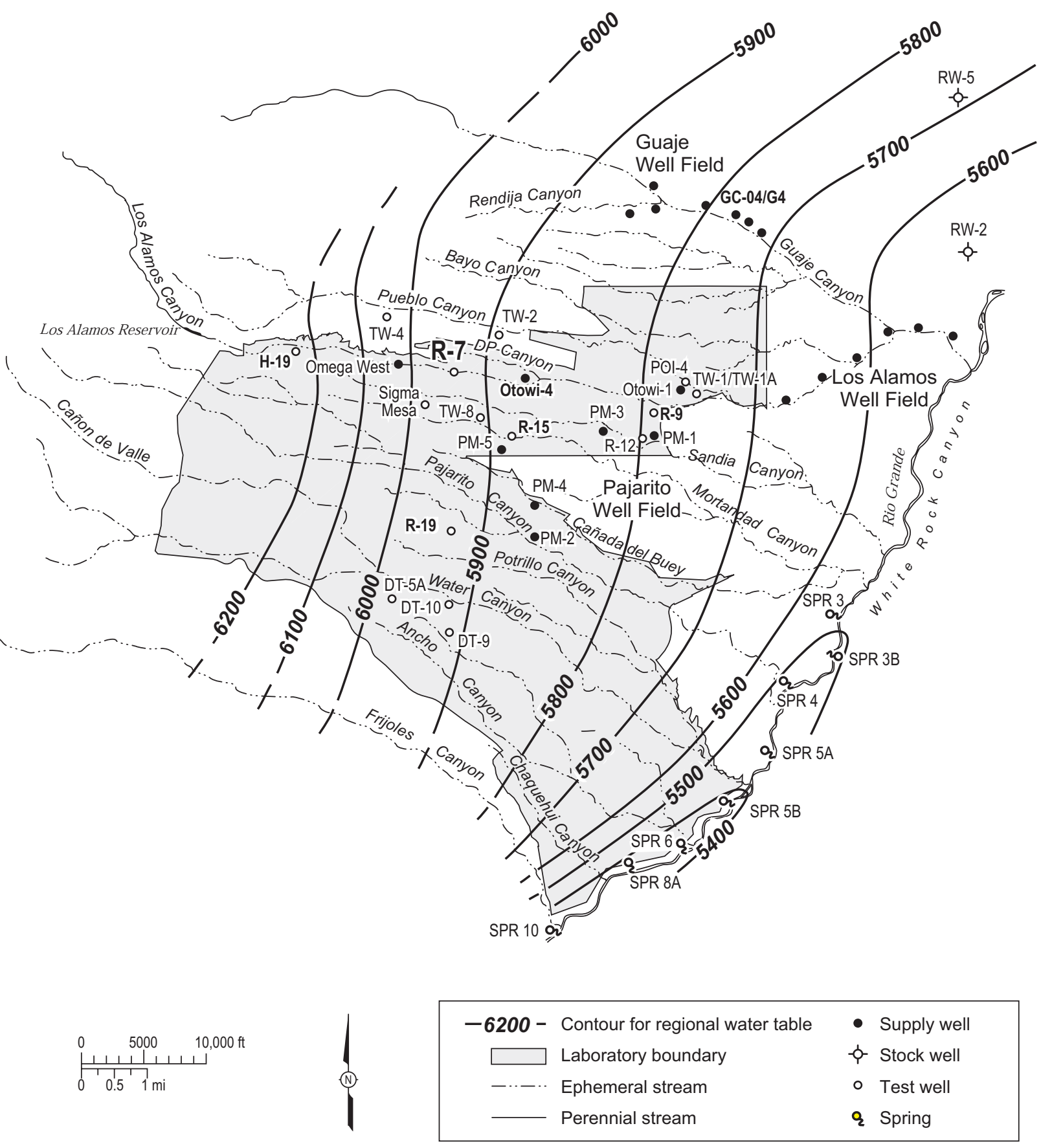

R-7 geochem rpt / 120502 / PTM

Figure 1.0-1. Locations of well R-7, selected water supply wells, test wells, and springs near the Rio Grande, and generalized water-level contours for the regional aquifer (from Stone et al. 2002, 72717) 


\subsection{DRILLING METHODS AND WELL DESIGN}

\subsection{Drilling Methods}

Well R-7 was drilled in two phases. Phase I was conducted during February and July 2000; however, drilling was interrupted for a few months because of the Cerro Grande fire in May 2000. Phase I drilling used a hollow-stem auger (HSA) method and reached a depth of $76 \mathrm{ft}$ within ash flows of the Otowi Member of the Bandelier Tuff (Stone et al. 2002, 72717). After several additional months of delay because of the fire, Phase II drilling was conducted from December 2000 through January 2001 using rotary methods that involved a combination of casing-advance and open-hole techniques. During Phase II, well R-7 was drilled to a depth of $1097 \mathrm{ft}$ and completed to a depth of $1086 \mathrm{ft}$. The well encounters clastic sedimentary rocks at the top of the Puye Formation at $347 \mathrm{ft}$ and bottoms in quartziterich river gravels tentatively assigned to the Totavi Lentil of the Puye Formation at $1087 \mathrm{ft}$ (Stone et al. 2002, 72717). Well R-7 is a multiscreen well containing three screened intervals. A Foremost ${ }^{\mathrm{TM}}$ dual rotation (DR)-24 drill rig was used during Phase II drilling, and the well was officially completed on March 9, 2001 (Stone et al. 2002, 72717). Surface completion and site restoration of well R-7 were finished on August 24, 2001.

During the second phase, drilling mud behind the casing was used for lubrication. TORKease ${ }^{\circledR}$ polymer, QUIKFOAM ${ }^{\circ}$, and EZ-MUD® bentonite slurries, mixed with community water obtained from a water line (spout) near the Los Alamos County landfill located at TA-61, were also used. These additives served to lubricate the outside of the casing system during drilling and to prevent binding the casing string to the borehole wall.

\subsection{Well Design}

Characterization well R-7 was designed as a multicompletion well with three pipe-based, wire-wrapped, stainless steel screens from 363.2 to $379.2 \mathrm{ft}, 730.4$ to $746.4 \mathrm{ft}$, and 895.5 to $937.4 \mathrm{ft}$ (Stone et al. 2002, 72717). A Westbay ${ }^{\circledR}$ Instrument, Inc., MP55® monitoring system was set in fanglomerates of the upper Puye Formation (screen \#1) and in pumiceous sedimentary rocks currently assigned to the lower Puye Formation (screens \#2 and \#3). Figure 2.2-1 shows final construction information for well R-7. Well development consisted of cleaning the screens with a wire brush, followed by bailing and pumping until the field parameters ( $\mathrm{pH}$, specific conductance, and turbidity) stabilized (Stone et al. 2002, 72717). After well development, the Westbay ${ }^{\circledR}$ MP55 System $®$ for groundwater monitoring was installed in the steelcased well. Model 2523 MOSDAX® System sampler-probe equipment was used to collect groundwater samples from the completed well.

\subsection{HYDROGEOLOGY}

\subsection{Hydrostratigraphy}

The principal hydrogeologic units penetrated in well R-7, in descending order, consist of alluvium, Otowi Member of the Bandelier Tuff, Guaje Pumice Bed, an upper clastic subunit of the Puye Formation, a lower pumiceous, clastic subunit of the Puye Formation, and a conglomeratic unit tentatively assigned to the Totavi Lentil of the Puye Formation (Stone et al. 2002, 72717). No saturation was encountered in either the Otowi Member ash flows or the Guaje Pumice Bed of the Bandelier Tuff. The first interval of perched water was encountered at depths between 362 and $382 \mathrm{ft}$ in the top of the Puye Formation. The perched water zone sits above a clay-rich zone extending to roughly $397 \mathrm{ft}$ in the Puye Formation. Screen \#1, with openings from 363 to $379 \mathrm{ft}$, is set this perched zone. 
Continuous saturation associated with the regional aquifer was encountered in the Puye Formation at depths between 879 to $899 \mathrm{ft}$ (Stone et al. 2002, 72717), roughly $45 \mathrm{ft}$ deeper than expected based on projections from other wells. Screen \#3 was placed at a depth of 895 to $937 \mathrm{ft}$ to sample groundwater near the top of the saturated portion of the regional aquifer.

Aquifer performance testing was not conducted at well R-7 because screens \#1 and \#2 were nonproductive. Screen \#3 straddles the regional water table and was not suitable for hydraulic (injection) testing because of unsaturated flow conditions in the upper portion of the screen.

\subsection{FIELD SAMPLING AND ANALYTICAL METHODS}

\subsection{Field Sampling Methods}

Because of the low-flow (3.8 liters per hour) sampling method used at Westbay ${ }^{\circledR}$-constructed wells, no casing volumes of groundwater were pumped or purged from well R-7 prior to groundwater sampling events. Field parameters including $\mathrm{pH}$, specific conductance, turbidity, dissolved oxygen, and temperature were recorded during each sampling event. A portable $\mathrm{HACH} \otimes$ digital titrator was used to measure field alkalinity during the sampling events.

Groundwater samples were collected using the Westbay $\AA$ MP55 system $®$ and were then analyzed for inorganic and organic chemicals, stable isotopes, and radionuclides. Temperature, turbidity, $\mathrm{pH}$, dissolved oxygen, alkalinity, and specific conductance were determined on-site from an aliquot collected during field sampling. Both filtered and nonfiltered samples were collected for chemical and radiochemical analyses. Only filtered samples were collected for analyses of isotopic americium, cesium, plutonium, strontium, and uranium during the third and fourth sampling events. Nonfiltered samples were analyzed for gross alpha, gross beta, gross gamma, and technetium-99 to provide a worst-case estimate of radioactivity in a groundwater sample. Groundwater samples were collected for analyses of dissolved organic carbon (DOC); total organic carbon (TOC); stable isotopes of hydrogen, oxygen, and nitrogen; major cations and anions; metals and trace elements; organic compounds; and radionuclides. Aliquots of the samples were filtered through a $0.45-\mu \mathrm{m}$ Gelman filter and acidified with analytical-grade $\mathrm{HNO}_{3}$ to a $\mathrm{pH}$ of 2.0 or less for major anion, metal, and radionuclide analyses. DOC samples were filtered with a special $0.45-\mu \mathrm{m}$ silver filter to eliminate biodegradation of organic solutes. All groundwater samples collected in the field were stored at $4^{\circ} \mathrm{C}$ until they were analyzed. The first round of groundwater characterization sampling took place approximately four months after well completion.

\subsection{Field Parameters}

Field-measured parameters for the groundwater samples, including $\mathrm{pH}$, temperature, specific conductance, dissolved oxygen, and turbidity, were measured following RRES-R Standard Operating Procedures (SOP) and are provided in Tables 4.2-1a and 4.2-1b. These parameters were measured at the time of sample collection when groundwater was in contact with the atmosphere. Temperature, specific conductance, and $\mathrm{pH}$ were measured with an Orion meter (model 1230); turbidity was measured with a HACH® meter (model 53600-00). Both meters were calibrated daily using buffer solutions $(\mathrm{pH} 4.0$ and 7.0) and known standards for turbidity. Dissolved oxygen was measured with a spectrophotometer ( $\mathrm{HACH} \circledast$ meter, model DR/2010) during the third and fourth sampling rounds. Field measurements were recorded with daily activity logs submitted to RRES and are included in the analytical results. Turbidity values for these samples were generally less than 3 nephelometric turbidity units ([NTUs] Tables 4.2-1a and 4.2-1b), with a value as high as 8.7 NTUs in screen \#3. 
Table 4.2-1a

Field-Measured Parameters for Groundwater Samples Collected at Well R-7, Screen \#1

\begin{tabular}{|l|l|l|l|l|}
\hline Geologic Unit & $\begin{array}{l}\text { Upper Puye } \\
\text { Formation }\end{array}$ & $\begin{array}{l}\text { Upper Puye } \\
\text { Formation }\end{array}$ & $\begin{array}{l}\text { Upper Puye } \\
\text { Formation }\end{array}$ & $\begin{array}{l}\text { Upper Puye } \\
\text { Formation }\end{array}$ \\
\hline Depth (ft) & $\mathbf{3 7 8 . 0}$ & $\mathbf{3 7 8 . 0}$ & $\mathbf{3 7 8 . 0}$ & $\mathbf{3 7 8 . 0}$ \\
\hline Date sampled (mo/d/yr) & $\mathbf{0 5 / 3 0 / 0 1}$ & $\mathbf{0 8 / 0 8 / 0 1}$ & $\mathbf{1 1 / 1 9 / 0 1}$ & $\mathbf{0 2 / 1 9 / 0 2}$ \\
\hline $\mathrm{pH}($ standard units) & 6.68 & 7.18 & 7.47 & 7.43 \\
\hline Dissolved oxygen $(\mathrm{mg} / \mathrm{L})$ & Not measured & Not measured & 2.7 & 6.1 \\
\hline Temperature $\left({ }^{\circ} \mathrm{C}\right)$ & 14.3 & 14.3 & 9.8 & 10.0 \\
\hline Specific conductance $\left(\mu \mathrm{S} / \mathrm{cm}^{\mathrm{a}}\right)$ & 131 & 75.6 & 92 & 97 \\
\hline Turbidity $\left(\mathrm{NTU}^{\mathrm{b}}\right)$ & 2.0 & 1.0 & 0.3 & 0.6 \\
\hline
\end{tabular}

${ }^{a}{ }_{\mu S / c m}=$ microsiemens per centimeter.

${ }^{b}$ NTU = nephelometric turbidity unit.

Table 4.2-1b

Field-Measured Parameters for Groundwater Samples Collected at Well R-7, Screen \#3

\begin{tabular}{|l|l|l|l|l|}
\hline Geologic Unit & $\begin{array}{l}\text { Lower Puye } \\
\text { Formation }\end{array}$ & $\begin{array}{l}\text { Lower Puye } \\
\text { Formation }\end{array}$ & $\begin{array}{l}\text { Lower Puye } \\
\text { Formation }\end{array}$ & $\begin{array}{l}\text { Lower Puye } \\
\text { Formation }\end{array}$ \\
\hline Depth (ft) & $\mathbf{9 1 5 . 0}$ & $\mathbf{9 1 5 . 0}$ & $\mathbf{9 1 5 . 0}$ & $\mathbf{9 1 5 . 0}$ \\
\hline Date sampled (mo/d/yr) & $\mathbf{0 5 / 3 1 / 0 1}$ & $\mathbf{0 8 / 0 9 / 0 1}$ & $\mathbf{1 1 / 2 7 / 0 1}$ & $\mathbf{0 2 / 2 1 / 0 2}$ \\
\hline $\mathrm{pH}($ standard units) & 6.91 & 6.81 & 7.24 & 7.28 \\
\hline Dissolved oxygen $(\mathrm{mg} / \mathrm{L})$ & Not measured & Not measured & 1.9 & 1.4 \\
\hline Temperature $\left({ }^{\circ} \mathrm{C}\right)$ & 19.0 & 17.4 & 10.5 & 13.3 \\
\hline Specific conductance $\left(\mu \mathrm{S} / \mathrm{cm}^{\mathrm{a}}\right)$ & 266 & 271 & 227 & 187 \\
\hline Turbidity $\left(\mathrm{NTU}{ }^{\mathrm{b}}\right)$ & 8.7 & 0.9 & 2.9 & 2.8 \\
\hline
\end{tabular}

${ }^{a} \mu \mathrm{S} / \mathrm{cm}=$ microsiemens per centimeter.

${ }^{b}$ NTU = nephelometric turbidity unit.

The temperatures of groundwater samples collected at well R-7 were recorded at land surface, and they ranged from 9.8 to $14.3^{\circ} \mathrm{C}$ for the perched zone (screen \#1) and from 10.5 to $19.0^{\circ} \mathrm{C}$ for the regional aquifer (screen \#3). The lowest temperature measurements were recorded in the fall of 2001. Variation in temperature reflects ambient surface temperature, even though temperature measurements were recorded immediately during sample collection.

\subsection{Analytical and Validation Methods}

\subsubsection{Analytical Methods}

Groundwater samples were analyzed using techniques specified in EPA SW-846 methods, including ion chromatography (IC) for bromide, chloride, fluoride, oxalate, nitrate plus nitrite, perchlorate, phosphate, and sulfate. Inductively coupled argon plasma optical emission spectroscopy (ICPOES) was the analytical method for trace elements (aluminum, arsenic, barium, boron, calcium, chromium, cobalt, copper, iron, magnesium, manganese, molybdenum, nickel, potassium, selenium, silicon [silica], silver, sodium, 
strontium, vanadium, and zinc). Total cyanide was analyzed by colorimetry (C), and mercury was analyzed by cold vapor atomic absorption (CVAA). Ammonium was analyzed by ion selective electrode (ISE). Total Kjeldahl nitrogen (TKN) was measured by distillation at Paragon Analytics, Inc., and General Engineering Laboratory (GEL). Antimony, beryllium, cadmium, lead, thallium, and uranium were analyzed by inductively coupled argon plasma mass spectrometry (ICPMS) during the first, second, third, and fourth sampling events. Manganese and molybdenum were also analyzed by ICPMS during the third and fourth sampling rounds.

The analytical work was performed by RRES-approved subcontractor laboratories, including Paragon Analytics, Inc., (IC, C, ISE, CVAA, and ICPOES methods for the first and second sampling events) and GEL (IC, C, ISE, CVAA, ICPOES, and ICPMS methods for the third and fourth sampling events). Alkalinity was determined in the Paragon and GEL laboratories using standard titration techniques. Laboratory blanks were analyzed according to EPA and LANL procedures. The precision limits for major ions and trace elements were generally $\pm 10 \%$. DOC fractionation was performed using an XAD- 8 column at Huffman Laboratories. (Elution of hydrophobic and hydrophilic organic compounds is based on physical adsorption.)

Tritium activity in groundwater was determined by electrolytic enrichment and direct counting. Radiometric methods included alpha spectrometry for americium, plutonium, and uranium isotopes; gamma spectrometry for cesium-137 and other gamma-emitting isotopes; gas proportional counting for strontium90; and liquid scintillation for technetium-99. These analyses were performed by contract laboratories, including Paragon Analytics, Inc., (radionuclides in first and second rounds); GEL (radionuclides in third and fourth rounds); and the University of Miami (low-level tritium).

Geochron Laboratories (Cambridge, Massachusetts) analyzed stable isotope ratios of oxygen $\left(\delta^{18} O\right)$ and hydrogen $(\delta D)$ using isotope ratio mass spectroscopy (IRMS). Coastal Science Laboratories, Inc., (Austin, Texas) analyzed nitrogen isotope ratios $\left(\delta^{15} \mathrm{~N}_{\mathrm{AIR}}-\mathrm{NO}_{3}\right)$ using IRMS.

Volatile and semivolatile organic compounds (VOCs and SVOCs), HE compounds, polychlorinated biphenyls, and pesticides were analyzed by high-pressure liquid chromatography and gas chromatography mass spectrometry. Paragon Analytics, Inc., (first and second rounds) and GEL (third and fourth rounds) performed these organic analyses.

\subsubsection{Validation Methods}

Data quality validation, performed according to RRES SOPs, was done on chemical and radiochemical analytical results for groundwater samples collected from well R-7. The validation process generally revealed no deficiencies except with selected organic analyses. Groundwater samples were analyzed within required holding times. Laboratory blanks, percent tracer recovery, laboratory duplicate samples, laboratory control samples, internal standards, spike recovery, and analyte concentrations relative to instrument detection and reporting (quantitation) limits were evaluated as part of the validation procedure. Field blanks for analyses of organic compounds were not collected during characterization sampling at well R-7. Charge-balance errors for analytical results were calculated for major and trace ions using the computer program MINTEQA2. Percent charge balance is defined as follows:

(100) $\left[\left(\sum\right.\right.$ milliequivalents cations $-\sum$ milliequivalents anions $)$ divided by

( $\sum$ milliequivalents cations $+\sum$ milliequivalents anions)] .

Equation 1

"Detection" of a chemical in groundwater is defined as finding an analyte concentration that exceeds the method detection level (MDL). Detection of a radionuclide in groundwater occurs if its activity exceeds $3 \sigma$ 
(three standard deviations of the measurement error) and the instrument minimum detectable activity (MDA). The $3 \sigma$ values for every radionuclide are contained in the RRES database and were included as part of data validation. A "nondetect" is defined as an analyte concentration that is recorded but is less than the MDL. The reporting limit $(R L)$ is defined as the instrument quantitation limit.

\subsection{GROUNDWATER ANALYTICAL RESULTS}

This section presents analytical results obtained during four sampling rounds conducted at well R-7 on May 30 and 31, 2001; August 8 and 9, 2001; November 19 and 26, 2001; and February 19 and 20, 2002. Analyte suites include major ions, trace elements, trace metals, radionuclides, stable isotopes, organic compounds, and DOC. The activities of tritium and concentrations of chloride at well R-7 indicate that it has not been impacted by Laboratory discharges.

Analytical results for well R-7 show that within the perched zone (screen \#1) and regional aquifer (screen \#3) contaminant concentrations were below standards, excluding total manganese with an EPA secondary standard of $0.05 \mathrm{mg} / \mathrm{L}$; total nickel with an EPA primary standard of $0.1 \mathrm{mg} / \mathrm{L}$; dissolved manganese with a New Mexico Water Quality Control Commission (NMWQCC) standard for water supply of $0.2 \mathrm{mg} / \mathrm{L}$; dissolved iron with a NMWQCC standard for water supply of $1 \mathrm{mg} / \mathrm{L}$; and dissolved nickel with a NMWQCC standard for irrigation use of $0.2 \mathrm{mg} / \mathrm{L}$. Elevated concentrations of manganese, nickel, and iron observed in the regional aquifer for several sampling rounds are probably derived from natural sources as a result of the reduction and dissolution of iron and manganese minerals in the presence of residual drilling fluids.

\subsection{Major lons, Metals, Radionuclides, Organic Compounds, and Stable Isotopes}

Groundwater samples were collected from the perched zone (screen \#1, $378.0 \mathrm{ft}$ ) and the regional aquifer (screen \#3, $915.0 \mathrm{ft}$ ). Measurements for both field-measured (nonfiltered) and fixed-laboratory (filtered) alkalinity are provided in Tables 5.1-1 and 5.1-2.

Selected results of inorganic and organic analytes measured at well R-7 are provided in Tables 5.1-1 and 5.1-2, and complete analytical results are provided in Appendix A. Groundwater sampled at this well had charge-balance errors, calculated by MINTEQA2 (Allison et al. 1991, 49930), that were generally less than $\pm 10 \%$. The positive charge-balance errors in Tables 5.1-1 and 5.1-2 indicate excess cations from analytical results, a finding that probably results from analytical errors that are within acceptable instrument precision $(< \pm 5 \%)$ associated with ICPOES at Paragon Analytics, Inc., and GEL. Negative charge-balance errors in Tables 5.1-1 and 5.1-2 indicate excess anions from analytical results, a finding that probably results from the measurement of alkalinity off-site at Paragon Analytics, Inc., and GEL.

Gross gamma, TOC, and DOC were not analyzed during some of the sampling events because of limited sample volumes collected from screens \#1 and \#3. The nonroutine parameters (TOC and DOC) did not need to be sampled quarterly. Analysis of stable isotopes of nitrogen requires a one-gallon sample if nitrate plus nitrite (as $\mathrm{N}$ ) and ammonium (as $\mathrm{N}$ ) concentrations are less than $1 \mathrm{mg} / \mathrm{L}$; however, typically one-liter samples were collected for this analysis because of sample volume limitations. 
Table 5.1-1

Hydrochemistry of Selected Analytes for Well R-7, Screen \#1

\begin{tabular}{|c|c|c|c|c|}
\hline Depth of Measurement Port (ft) & 378.0 & 378.0 & 378.0 & 378.0 \\
\hline Geologic Unit & $\begin{array}{l}\text { Upper Puye } \\
\text { Formation }\end{array}$ & $\begin{array}{l}\text { Upper Puye } \\
\text { Formation }\end{array}$ & $\begin{array}{l}\text { Upper Puye } \\
\text { Formation }\end{array}$ & $\begin{array}{l}\text { Upper Puye } \\
\text { Formation }\end{array}$ \\
\hline Sample Treatment & Filtered & Filtered & Filtered & Filtered \\
\hline Date Sampled (mo/d/yr) & $05 / 30 / 01$ & $06 / 19 / 01$ & $11 / 19 / 01$ & 02/19/02 \\
\hline Alkalinity $\left(\mathrm{CaCO}_{3} \mathrm{mg} / \mathrm{L}\right)$ & 41 Field, 67 Lab & 31 Field, 46 Lab & 39 Field, 20 Lab & 46 Field, $21 \mathrm{Lab}$ \\
\hline $\mathrm{Ca}(\mathrm{mg} / \mathrm{L})$ & 16.0 & 10.0 & 9.26 & 7.15 \\
\hline $\mathrm{Mg}(\mathrm{mg} / \mathrm{L})$ & 2.0 & 1.7 & 1.4 & 1.43 \\
\hline $\mathrm{Na}(\mathrm{mg} / \mathrm{L})$ & 5.9 & 5.7 & 6.39 & 6.29 \\
\hline $\mathrm{K}(\mathrm{mg} / \mathrm{L})$ & 3.3 & 3.0 & 3.06 & 3.18 \\
\hline $\mathrm{Cl}(\mathrm{mg} / \mathrm{L})$ & 1.60 & 2.0 & 1.0 & 1.56 \\
\hline $\mathrm{SiO}_{2}(\mathrm{mg} / \mathrm{L})$ & 64.2 & 64.2 & 65.1 & 57.4 \\
\hline $\mathrm{SO}_{4}(\mathrm{mg} / \mathrm{L})$ & 2.9 & 2.5 & 1.8 & 2.27 \\
\hline $\mathrm{NH}_{4}($ as N) (mg/L) & {$[0.10], \mathrm{U}^{\mathrm{a}}$} & {$[0.10], U$} & [0.05], U & [0.05], U \\
\hline $\mathrm{B}(\mathrm{mg} / \mathrm{L})$ & 0.012 & {$[0.016], U$} & {$[0.05] . \mathrm{U}$} & [0.05], U \\
\hline $\mathrm{Ba}(\mathrm{mg} / \mathrm{L})$ & 0.074 & 0.084 & 0.075 & 0.056 \\
\hline $\mathrm{ClO}_{4}(\mathrm{mg} / \mathrm{L})$ & [0.004], U & [0.004], U & [0.004], U & [0.004], U \\
\hline $\mathrm{F}(\mathrm{mg} / \mathrm{L})$ & 0.22 & 0.15 & [0.05], U & 0.08 \\
\hline $\mathrm{Fe}(\mathrm{mg} / \mathrm{L})$ & [0.07], U & 0.01 & [0.05], U & [0.05], U \\
\hline $\mathrm{Mn}(\mathrm{mg} / \mathrm{L})$ & 0.08 & 0.11 & 0.083 & 0.050 \\
\hline Mo (mg/L) & 0.0038 & [0.0041], U & 0.0020 & 0.0017 \\
\hline $\mathrm{Ni}(\mathrm{mg} / \mathrm{L})$ & 0.0017 & 0.0025 & {$[0.005], U$} & {$[0.005], U$} \\
\hline $\mathrm{NO}_{3}+\mathrm{NO}_{2}($ as $\mathrm{N})(\mathrm{mg} / \mathrm{L})$ & 0.10 & 0.22 & 0.19 & 0.27 \\
\hline $\mathrm{Sr}(\mathrm{mg} / \mathrm{L})$ & 0.073 & 0.052 & 0.044 & 0.038 \\
\hline $\mathrm{P}$ (total) (mg/L) & [0.05], U & [0.05], U & 0.04 & [0.050], U \\
\hline $\mathrm{DOC}(\mathrm{mgC} / \mathrm{L})$ & 2.2 & Not analyzed & 0.85 & 0.67 \\
\hline $\mathrm{TOC}(\mathrm{mgC} / \mathrm{L}), \mathrm{NF}^{\mathrm{b}}$ & 2.60 & Not analyzed & 0.68 & 0.24 \\
\hline TKN (mg/L) & 0.20 & 0.31 & 0.25 & [0.10], U \\
\hline $\mathrm{U}(\mathrm{mg} / \mathrm{L})$ & 0.000167 & 0.000252 & {$[0.0002], \mathrm{U}$} & {$[0.0002], \mathrm{U}$} \\
\hline $\mathrm{TDS}^{\mathrm{C}}$ (mg/L) (calculated) & 163 & 121 & 127 & 126 \\
\hline$M Q^{d}$ cations & 1.310 & 0.7609 & 0.9387 & 0.8330 \\
\hline MEQ anions & 1.465 & 0.7513 & 0.8624 & 1.034 \\
\hline Charge Balance (\%) & -5.58 & +0.63 & +4.24 & -10.76 \\
\hline Am-241 (pCi/L), $F^{e}$ & [0.009], U & {$[-0.003], \cup$} & [0.0087], U & [0.0186], U \\
\hline Cs-137 (pCi/L), F & {$[0.1], \mathrm{U}$} & Not analyzed & [1.29], U & [0.0294], U \\
\hline $\mathrm{Pu}-238$ (pCi/L), F & [0.002], U & {$[0], U$} & {$[0], \mathrm{U}$} & {$[-0.0008], U$} \\
\hline $\mathrm{Pu}-239,240$ (pCi/L), F & [0.01], U & [0.011], U & {$[-0.0021], U$} & {$[-0.0008], U$} \\
\hline Sr-90 (pCi/L), F & {$[0], U$} & {$[0.5], \mathrm{U}$} & {$[-0.0037], U$} & {$[-0.0499], U$} \\
\hline Tc-99 (pCi/L), NF & {$[1.1], \mathrm{U}$} & [0.62], U & [2.47], U & {$[-3.8], \mathrm{U}$} \\
\hline Tritium (pCi/L), NF & 2.55 & 3.38 & 2.74 & 3.26 \\
\hline
\end{tabular}


Table 5.1-1 (continued)

\begin{tabular}{|l|l|l|l|l|}
\hline Depth of Measurement Port (ft) & $\mathbf{3 7 8 . 0}$ & $\mathbf{3 7 8 . 0}$ & $\mathbf{3 7 8 . 0}$ & $\mathbf{3 7 8 . 0}$ \\
\hline Geologic Unit & $\begin{array}{l}\text { Upper Puye } \\
\text { Formation }\end{array}$ & $\begin{array}{l}\text { Upper Puye } \\
\text { Formation }\end{array}$ & $\begin{array}{l}\text { Upper Puye } \\
\text { Formation }\end{array}$ & $\begin{array}{l}\text { Upper Puye } \\
\text { Formation }\end{array}$ \\
\hline Date Sampled (mo/d/yr) & $\mathbf{0 5 / 3 0 / 0 1}$ & $\mathbf{0 8 / 0 8 / 0 1}$ & $\mathbf{1 1 / 1 9 / 0 1}$ & $\mathbf{0 2 / 1 9 / 0 2}$ \\
\hline Gross alpha (pCi/L), NF & {$[0.31], \mathrm{U}$} & {$[0.1], \mathrm{U}$} & {$[0.456], \mathrm{U}$} & {$[0.478], \mathrm{U}$} \\
\hline Gross beta (pCi/L), NF & 3.8 & 4.5 & 2 & 3.02 \\
\hline Gross gamma (pCi/L), NF & 181 & 123 & Not analyzed & Not analyzed \\
\hline U-234 (pCi/L), F & {$[0.071], \mathrm{U}$} & {$[0.109], \mathrm{U}$} & 0.05 & 0.0478 \\
\hline $\mathrm{U}-235(\mathrm{pCi} / \mathrm{L}), \mathrm{F}$ & {$[0.005], \mathrm{U}$} & {$[0.032], \mathrm{U}$} & {$[0.0046], \mathrm{U}$} & {$[0.0053], \mathrm{U}$} \\
\hline $\mathrm{U}-238(\mathrm{pCi} / \mathrm{L}), \mathrm{F}$ & {$[0.037], \mathrm{U}$} & {$[0.042], \mathrm{U}$} & {$[0.0113], \mathrm{U}$} & {$[0.0106], \mathrm{U}$} \\
\hline$\delta \mathrm{D}(\%), \mathrm{NF}$ & -81 & -80 & -81 & -80 \\
\hline$\delta^{15} \mathrm{~N}\left(\mathrm{NH}_{3}\right)(\%), \mathrm{NF}$ & Not analyzed & Not analyzed & Not analyzed & Not analyzed \\
\hline$\delta^{15} \mathrm{~N}\left(\mathrm{NO}_{3}\right)(\%), \mathrm{NF}$ & Not analyzed & +1.7 & +3.3 & $\begin{array}{l}\text { Insufficient } \\
\text { sample volume }\end{array}$ \\
\hline$\delta^{18} \mathrm{O}(\%), \mathrm{NF}$ & -11.5 & -11.5 & -11.7 & -11.5 \\
\hline
\end{tabular}

$\mathrm{a}_{\mathrm{U}}=$ not detected.

${ }^{\mathrm{b}} \mathrm{NF}=$ nonfiltered.

${ }^{\mathrm{C}}$ TDS $=$ total dissolved solids.

${ }^{d} \mathrm{MEQ}=$ milliequivalents.

${ }^{\mathrm{e}} \mathrm{F}=$ filtered.

${ }^{\mathrm{f}}$ Nitrate $(\mathrm{N})$ and ammonium $(\mathrm{N})$ concentrations less than $1 \mathrm{mg} / \mathrm{L}$ require a one-gallon sample to measure $\delta^{15} \mathrm{~N}$. 
Table 5.1-2

Hydrochemistry of Selected Analytes for Well R-7, Screen \#3

\begin{tabular}{|c|c|c|c|c|}
\hline Depth of Measurement Port (ft) & 915.0 & 915.0 & 915.0 & 915.0 \\
\hline Geologic Unit & $\begin{array}{l}\text { Lower Puye } \\
\text { Formation }\end{array}$ & $\begin{array}{l}\text { Lower Puye } \\
\text { Formation }\end{array}$ & $\begin{array}{l}\text { Lower Puye } \\
\text { Formation }\end{array}$ & $\begin{array}{l}\text { Lower Puye } \\
\text { Formation }\end{array}$ \\
\hline Sample Treatment & Filtered & Filtered & Filtered & Filtered \\
\hline Date Sampled (mo/d/yr) & $05 / 31 / 01$ & $08 / 09 / 01$ & $11 / 26 / 01$ & $02 / 20 / 02$ \\
\hline Alkalinity $\left(\mathrm{CaCO}_{3} \mathrm{mg} / \mathrm{L}\right)$ & 91 Field, 120 Lab & 98 Field, 110 Lab & 116 Field, 79 Lab & 114 Field, 54 Lab \\
\hline $\mathrm{Ca}(\mathrm{mg} / \mathrm{L})$ & 25.0 & 22.0 & 18.9 & 15.2 \\
\hline $\mathrm{Mg}(\mathrm{mg} / \mathrm{L})$ & 5.4 & 5.3 & 5.1 & 4.3 \\
\hline $\mathrm{Na}(\mathrm{mg} / \mathrm{L})$ & 9.4 & 10.0 & 12.2 & 11.8 \\
\hline $\mathrm{K}(\mathrm{mg} / \mathrm{L})$ & 3.4 & 3.0 & 2.7 & 2.3 \\
\hline $\mathrm{Cl}(\mathrm{mg} / \mathrm{L})$ & 2.4 & 2.5 & 1.38 & 1.98 \\
\hline $\mathrm{SiO}_{2}(\mathrm{mg} / \mathrm{L})$ & 47.1 & 44.9 & 48.2 & 53.3 \\
\hline $\mathrm{SO}_{4}(\mathrm{mg} / \mathrm{L})$ & {$[1.0], \mathrm{U}^{\mathrm{a}}$} & {$[1.0], \mathrm{U}$} & {$[0.20], \mathrm{U}$} & 0.41 \\
\hline $\mathrm{NH}_{4}($ as $\mathrm{N})(\mathrm{mg} / \mathrm{L})$ & 0.42 & 0.46 & 0.45 & 0.38 \\
\hline As (mg/L) & {$[0.0015], \mathrm{U}$} & [0.002], U & [0.005], U & 0.00579 \\
\hline $\mathrm{B}(\mathrm{mg} / \mathrm{L})$ & 0.082 & [0.024], U & 0.008 & 0.0045 \\
\hline $\mathrm{Ba}(\mathrm{mg} / \mathrm{L})$ & 0.230 & 0.240 & 0.216 & 0.172 \\
\hline $\mathrm{ClO}_{4}(\mathrm{mg} / \mathrm{L})$ & [0.004], U & {$[0.004], \mathrm{U}$} & {$[0.004], U$} & [0.004], U \\
\hline $\mathrm{F}(\mathrm{mg} / \mathrm{L})$ & 0.34 & 0.40 & [0.05], U & 0.33 \\
\hline $\mathrm{Fe}(\mathrm{mg} / \mathrm{L})$ & 17.0 & 14.0 & 12.4 & 8.75 \\
\hline $\mathrm{Mn}(\mathrm{mg} / \mathrm{L})$ & 3.20 & 3.40 & 3.08 & 2.32 \\
\hline Mo (mg/L) & 0.031 & 0.019 & 0.016 & 0.012 \\
\hline $\mathrm{Ni}(\mathrm{mg} / \mathrm{L})$ & 0.210 & 0.120 & 0.048 & 0.028 \\
\hline $\mathrm{NO}_{3}+\mathrm{NO}_{2}$ (as N) (mg/L) & [0.05], U & [0.05], U & 0.05 & [0.05], U \\
\hline $\mathrm{Sr}(\mathrm{mg} / \mathrm{L})$ & 0.160 & 0.140 & 0.117 & 0.092 \\
\hline $\mathrm{P}$ (total) $(\mathrm{mg} / \mathrm{L})$ & [0.05], U & [0.05], U & 0.07 & 0.02 \\
\hline $\mathrm{DOC}(\mathrm{mgC} / \mathrm{L})$ & 8.3 & Not analyzed & 4.0 & 3.2 \\
\hline $\mathrm{TOC}(\mathrm{mgC} / \mathrm{L}), \mathrm{NF}^{\mathrm{b}}$ & 2.6 & 9.2 & 6.5 & 3.7 \\
\hline TKN (mg/L) & 1.60 & 1.30 & 0.94 & 1.06 \\
\hline$U(\mathrm{mg} / \mathrm{L})$ & 0.000084 & 0.000051 & [0.0002], U & [0.00012], U \\
\hline TDS $^{\mathrm{C}}(\mathrm{mg} / \mathrm{L})$ (calculated) & 234 & 216 & 221 & 215 \\
\hline $\mathrm{MEQ}^{\mathrm{d}}$ cations & 2.928 & 2.682 & 2.519 & 2.088 \\
\hline MEQ anions & 2.498 & 2.300 & 2.371 & 2.363 \\
\hline Charge Balance (\%) & +7.93 & +7.66 & +3.04 & -6.17 \\
\hline $\mathrm{Am}-241(\mathrm{pCi} / \mathrm{L}), \mathrm{F}^{\mathrm{e}}$ & [0.022], U & [0.019], U & {$[0.0118], \mathrm{U}$} & [0.00373], U \\
\hline $\mathrm{Cs}-137$ (pCi/L), F & {$[-0.1], \cup$} & Not analyzed & {$[0.414], \mathrm{U}$} & {$[-0.682], \mathrm{U}$} \\
\hline $\mathrm{Pu}-238$ (pCi/L), F & {$[-0.002], \mathrm{U}$} & [0.029], U & [-0.00448], U & [0.00477], U \\
\hline Pu-239,240 (pCi/L), F & [0.017], U & [0.004], U & [0.00447], U & {$[0.00716], \mathrm{U}$} \\
\hline $\mathrm{Sr}-90$ (pCi/L), F & {$[1.4], \mathrm{U}$} & {$[0.9], \mathrm{U}$} & [0.0329], U & {$[-0.00477], \mathrm{U}$} \\
\hline Tc-99 (pCi/L), NF & {$[0.02], \mathrm{U}$} & {$[-1.57], U$} & {$[0.457], \mathrm{U}$} & {$[-3.35], \mathrm{U}$} \\
\hline Tritium (pCi/L), NF & 2.52 & 1.47 & 1.72 & 1.34 \\
\hline Gross alpha (pCi/L), NF & 2 & 2.9 & 2.32 & [1.5], U \\
\hline Gross beta (pCi/L), NF & 4.3 & 3.9 & 3.25 & 2.59 \\
\hline Gross gamma (pCi/L), NF & 152 & 122 & Not analyzed & \begin{tabular}{|l|} 
Not analyzed \\
\end{tabular} \\
\hline $\mathrm{U}-234(\mathrm{pCi} / \mathrm{L}), \mathrm{F}$ & [0.058], U & {$[0.076], \mathrm{U}$} & 0.0602 & 0.0664 \\
\hline
\end{tabular}


Table 5.1-2 (continued)

\begin{tabular}{|l|l|l|c|l|}
\hline Depth of Measurement Port (ft) & $\mathbf{9 1 5 . 0}$ & $\mathbf{9 1 5 . 0}$ & $\mathbf{9 1 5 . 0}$ & $\mathbf{9 1 5 . 0}$ \\
\hline Geologic Unit & $\begin{array}{l}\text { Lower Puye } \\
\text { Formation }\end{array}$ & $\begin{array}{l}\text { Lower Puye } \\
\text { Formation }\end{array}$ & $\begin{array}{l}\text { Lower Puye } \\
\text { Formation }\end{array}$ & $\begin{array}{l}\text { Lower Puye } \\
\text { Formation }\end{array}$ \\
\hline Date Sampled (mo/d/yr) & $\mathbf{0 5 / 3 1 / 0 1}$ & $\mathbf{0 8 / 0 9 / 0 1}$ & $\mathbf{1 1 / 2 6 / 0 1}$ & $\mathbf{0 2 / 2 0 / 0 2}$ \\
\hline $\mathrm{U}-235(\mathrm{pCi} / \mathrm{L}), \mathrm{F}$ & {$[0.009], \mathrm{U}$} & {$[0.036], \mathrm{U}$} & {$[0.00787], \mathrm{U}$} & {$[0.0074], \mathrm{U}$} \\
\hline $\mathrm{U}-238(\mathrm{pCi} / \mathrm{L}), \mathrm{F}$ & 0.07 & {$[0.062], \mathrm{U}$} & {$[0.0262], \mathrm{U}$} & {$[0.0344], \mathrm{U}$} \\
\hline$\delta \mathrm{D}(\%), \mathrm{NF}$ & -79 & -78 & -79 & -83 \\
\hline$\delta^{15} \mathrm{~N}\left(\mathrm{NH}_{3}\right)(\%), \mathrm{NF}$ & Not analyzed & $\begin{array}{l}\text { Insufficient } \\
\text { sample volume }\end{array}$ & $\begin{array}{l}\text { Insufficient } \\
\text { sample volume }\end{array}$ & Not analyzed \\
\hline$\delta^{15} \mathrm{~N}\left(\mathrm{NO}_{3}\right)(\%), \mathrm{NF}$ & $\begin{array}{l}\text { Insufficient } \\
\text { sample volume }\end{array}$ & +0.9 & +1.7 & $\begin{array}{l}\text { Insufficient } \\
\text { sample volume }\end{array}$ \\
\hline$\delta^{18} \mathrm{O}(\%), \mathrm{NF}$ & -11.4 & -11.3 & -11.5 & -11.5 \\
\hline
\end{tabular}

$\mathrm{a}_{\mathrm{U}}=$ not detected.

${ }^{\mathrm{b}} \mathrm{NF}=$ nonfiltered.

${ }^{\mathrm{C}}$ TDS $=$ total dissolved solids

${ }^{d} M E Q=$ milliequivalents.

${ }^{e} F=$ filtered.

${ }^{\mathrm{f}}$ Nitrate $(\mathrm{N})$ and ammonium $(\mathrm{N})$ concentrations less than $1 \mathrm{mg} / \mathrm{L}$ require a one-gallon sample to measure $\delta^{15} \mathrm{~N}$.

Concentrations of alkalinity, in bold in Tables 5.1-1 and 5.1-2 above, were used for discussion in this report. Alkalinity was measured in the field and in an analytical laboratory; generally field-measured alkalinity is more representative of groundwater conditions because of sample degassing prior to titration. Degassing of carbon dioxide results in higher $\mathrm{pH}$ values that cause a change in concentrations of bicarbonate and carbonate. The carbonate anion becomes more stable over bicarbonate at higher $\mathrm{pH}$ values $\left(10.33\right.$ at $25^{\circ} \mathrm{C}$ ). The most consistent alkalinity concentrations (in bold in Tables 5.1-1 and 5.1-2) provided the lowest charge-balance errors.

Distributions of major solutes in groundwater sampled from well R-7 are shown in Figures 5.1-1 and 5.1-2. Groundwater within the perched zone and regional aquifer consists of a calcium-sodiumbicarbonate ionic composition within the Puye Formation (screens \#1 and \#3) (Figures 5.1-1 and 5.1-2). Groundwater collected from $378.0 \mathrm{ft}$ has the lowest concentrations of major solutes and may approximate predrilling groundwater at well R-7.

Calculated total dissolved solids (TDS) in the perched zone (screen \#1) ranged from 121 to $163 \mathrm{mg} / \mathrm{L}$ (Table 5.1-1). Calculated TDS in the regional aquifer (screen \#3) ranged from 215 to $234 \mathrm{mg} / \mathrm{L}$ (Table 5.1-2). Average detectable concentrations of dissolved chloride, fluoride, nitrate plus nitrite (as $N$ ), and sulfate were $1.54,0.15,0.19$, and $2.37 \mathrm{mg} / \mathrm{L}$, respectively, within the perched zone at a depth of $378.0 \mathrm{ft}$ (Table 5.1-1). Average detectable concentrations of dissolved chloride, fluoride, nitrate plus nitrite (as $\mathrm{N}$ ), and sulfate were 2.06, 0.36, 0.05 (single detection), and 0.41 (single detection) $\mathrm{mg} / \mathrm{L}$, respectively, within the regional aquifer in screen \#3 (Table 5.1-2). Low concentrations of chloride in both saturated zones suggest that well R-7 has not been impacted by Laboratory discharges and/or road salt that contains sodium and chloride. 


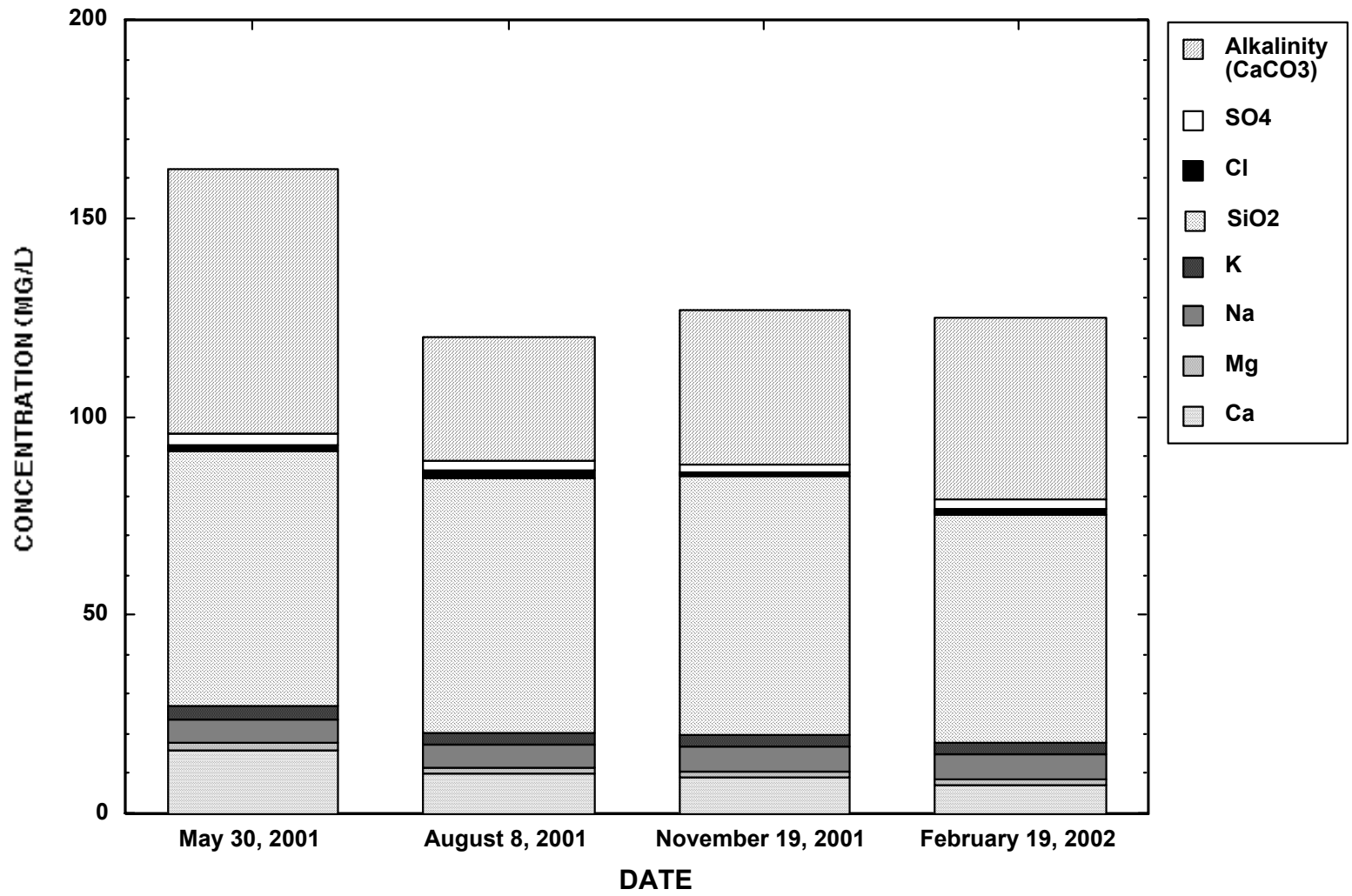

Figure 5.1-1. Major ion chemistry for well R-7 (perched zone, $378.0 \mathrm{ft}$ ), screen \#1

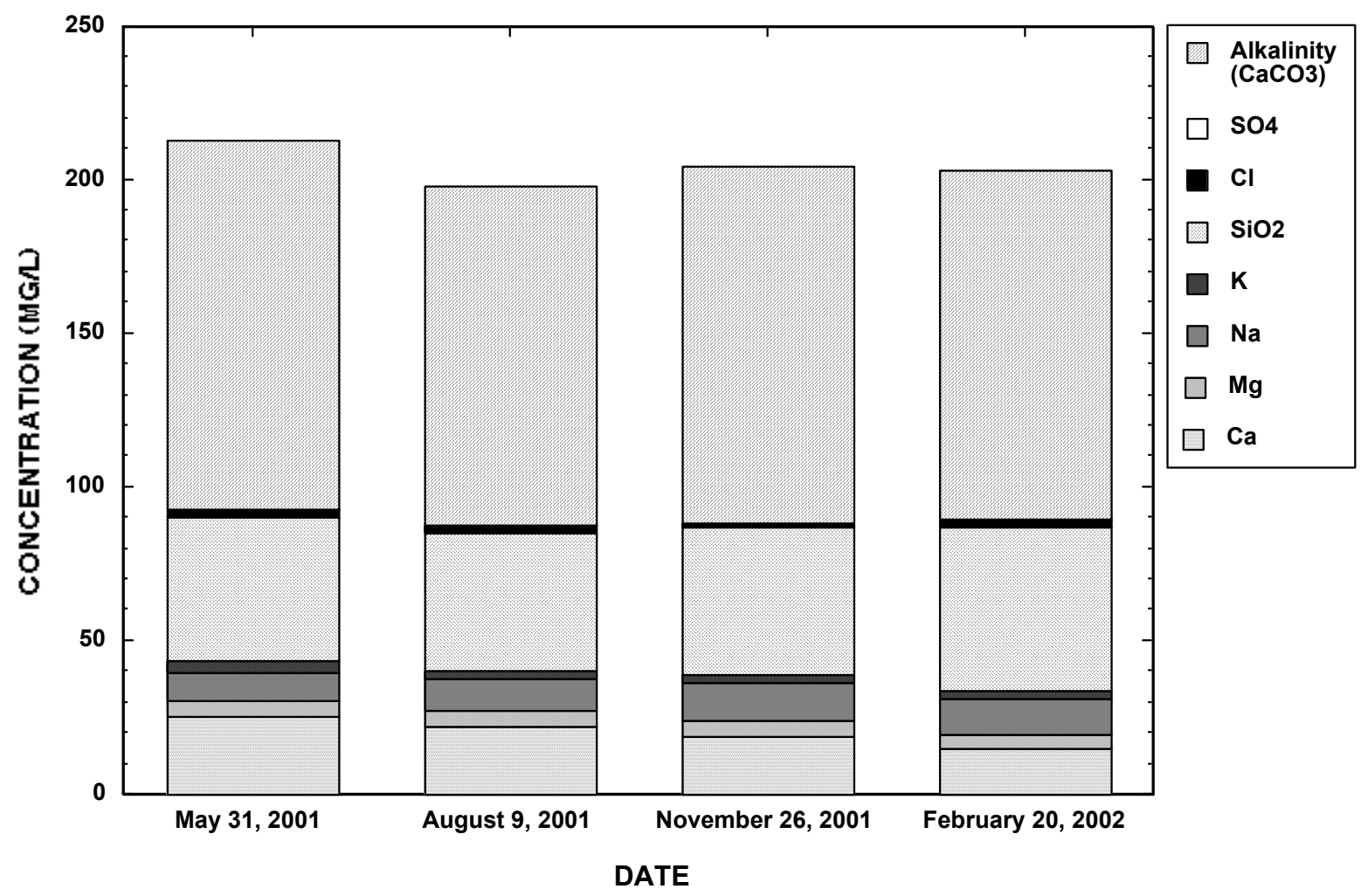

Figure 5.1-2. Major ion chemistry for well R-7 (regional aquifer, $915.0 \mathrm{ft}$ ), screen \#3 
Concentrations of sulfate in the regional aquifer at well R-7 were less than detection $(0.20$ and $1.0 \mathrm{mg} / \mathrm{L})$ in three out of four groundwater samples collected from screen \#3. Decreasing concentrations of dissolved oxygen and sulfate and increasing concentrations of dissolved iron and manganese suggest that reducing conditions have been established in the regional aquifer because of residual drilling fluids. Reduction of sulfate (electron acceptor) occurs during oxidation of organic carbon (electron donor) present in EZ-MUD® and other residual drilling fluids (Longmire 2002, 72800; Longmire 2002, 73282; Longmire 2002, 73676). Petroleum and/or sulfide odors were detected in the field for samples collected from screen \#3 during several sampling events. Manganese, iron, and sulfate are electron acceptors based on elevated concentrations of reduced manganese and iron, the absence of sulfate, and the presence of sulfide odor at well R-7.

Figure 5.1-3 shows distributions of dissolved ammonium, TKN, iron, sulfate, manganese, and DOC in the regional aquifer (screen \#3) in well R-7. Elevated concentrations of DOC occurred in samples collected from screen \#3 because of residual drilling fluid. Reductive dissolution of ferric (oxy)hydroxide and manganese dioxide is evident based on elevated concentrations of dissolved and total iron and manganese (Appendix A) in groundwater samples collected from screen \#3. Ammonium and TKN were associated with each other in the regional aquifer at 915.0 (Figure 5.1-3), which suggests that EZ-MUD® has been dissociating. At well R-7, the regional aquifer showed TKN concentrations ranging from 0.94 $\mathrm{mg} / \mathrm{L}$ to $1.60 \mathrm{mg} / \mathrm{L}$ (Table 5.1-2); TKN represents complex forms of organic nitrogen that are associated with $\mathrm{EZ}-\mathrm{MUD} \otimes$. Concentrations of sulfate are generally less than detection $(\leq 1 \mathrm{mg} / \mathrm{L})$ in groundwater samples collected from screen \#3 (Table 5.1-2), suggesting that sulfate reduction is occurring.

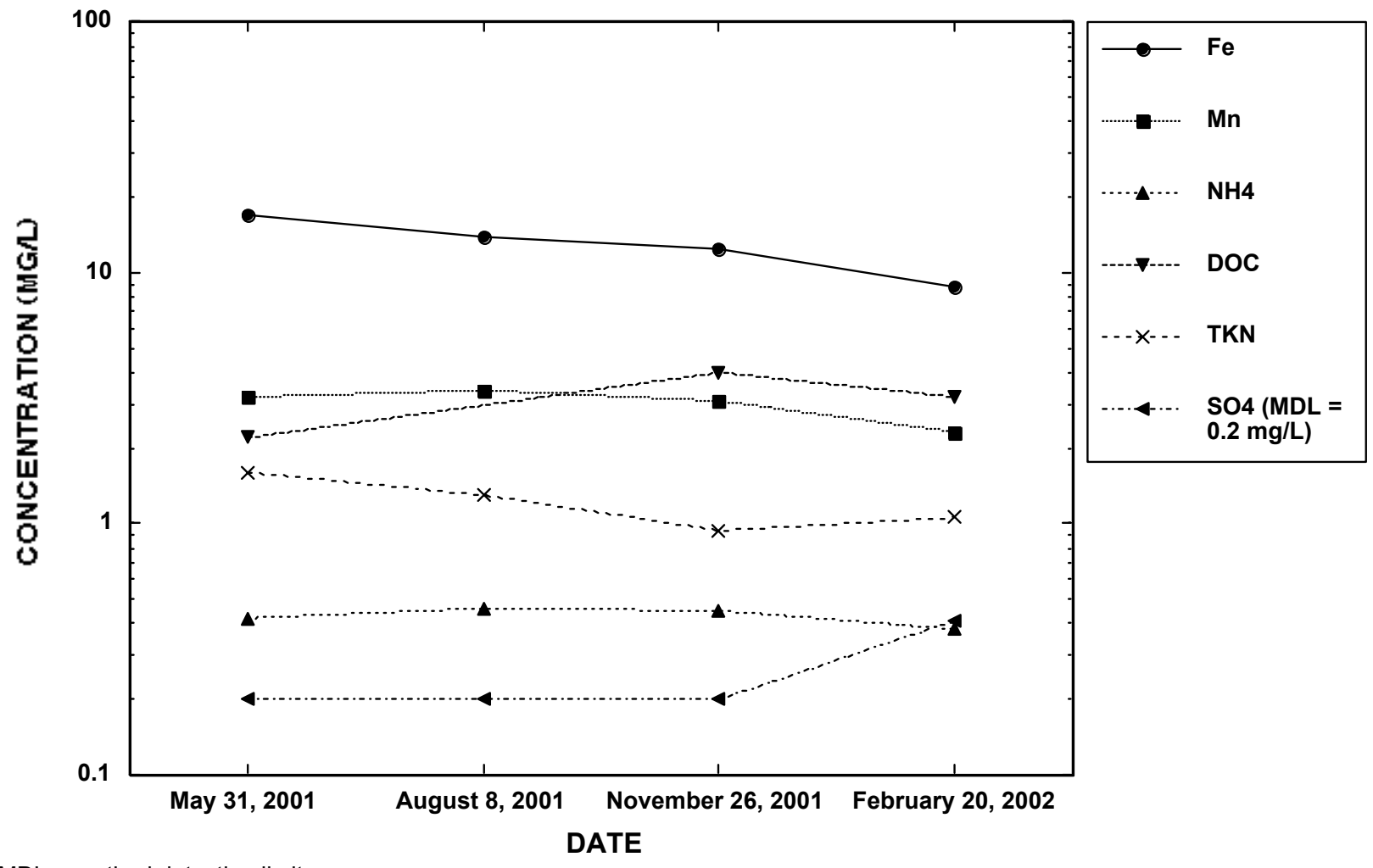

$\mathrm{MDL}=$ method detection limit

Figure 5.1-3. Concentrations of dissolved iron, manganese, ammonium, dissolved organic carbon, total Kjeldahl nitrogen, and sulfate versus time at well R-7, screen \#3 (915.0 ft). 
Residual drilling fluid (EZ-MUD®) present in well R-7 influences the water chemistry by providing organic carbon and nitrogen, which affect the oxidation-reduction chemistry of groundwater adjacent to the well screens. Longmire $(2002,72800)$ provides a detailed discussion of the chemistry of EZ-MUD $\circledast$ and its associated breakdown products, including ammonium and TKN, in well R-12. Ammonium is less mobile in groundwater relative to nitrate and nitrite (as $\mathrm{N}$ ) because of cation exchange. Concentrations of detectable ammonium (as $\mathrm{N}$ ) ranged from 0.38 to $0.46 \mathrm{mg} / \mathrm{L}$ within the regional aquifer (Table 5.1-2). Nitrate is stable under oxidizing conditions and can be reduced to nitrogen gas in the presence of denitrifying bacteria and electron donors such as $\mathrm{DOC}$ and reduced manganese [Mn(II)] and iron [Fe(II)] (Langmuir 1997, 56037). Nitrate and nitrite (as N) are stable as anions and are generally conservative (mobile) in aqueous systems under oxidizing conditions (Langmuir 1997, 56037).

Elevated TOC values measured during the four sampling events at well R-7 indicate the presence of residual drilling fluid (EZ-MUD®) within the regional aquifer. Groundwater samples collected from the regional aquifer showed an average TOC concentration of $5.5 \mathrm{mgC} / \mathrm{L}$ (range of 2.6 to $9.2 \mathrm{mgC} / \mathrm{L}$ ) (Table 5.1-2). Concentrations of TOC varied during characterization sampling of the regional aquifer, indicating that EZ-MUD® is oxidizing to inorganic carbon. The reactions discussed above indicate that the regional aquifer groundwater at well R-7 is temporarily reducing with respect to sulfate (screen \#3) and nitrogen (screen \#3). Hydrogen sulfide (in the forms of $\mathrm{H}_{2} \mathrm{~S}^{0}$ and $\mathrm{HS}^{-}$), ammonium, TKN, and TOC are the stable species in the region of the borehole under temporary reducing conditions imposed by the breakdown or dissociation of residual drilling fluids.

Dissolved silica in the form of $\mathrm{Si}(\mathrm{OH})_{4}{ }^{0}$ was the second most abundant solute in the perched zone and regional aquifer at well $\mathrm{R}-7$. Concentrations of dissolved silica ranged from 44.9 to $53.3 \mathrm{mg} / \mathrm{L}$ and from 57.4 to $65.1 \mathrm{mg} / \mathrm{L}$ within the regional aquifer and perched zone, respectively. Concentrations of perchlorate at well R-7 were less than detection (Tables 5.1-1 and 5.1-2). According to the subcontractor laboratory, the MDL and RL for the IC analysis of perchlorate were 0.004 and $0.012 \mathrm{mg} / \mathrm{L}$, respectively.

The following section provides a discussion of redox potential calculated from the $\mathrm{Fe}^{2+} / \mathrm{Fe}(\mathrm{OH})_{3}$ redox couple at ferrous iron concentrations above $8 \mathrm{mg} / \mathrm{L}$. Concentrations of detectable dissolved iron in the regional aquifer ranged from 8.75 to $17.0 \mathrm{mg} / \mathrm{L}$, suggesting that the regional aquifer groundwater adjacent to well screen \#3 is temporarily reducing with respect to iron because of residual drilling fluids. Calculated oxidation-reduction potential (Eh) values for screen \#3 ranged between -12.4 millivolts $(\mathrm{mV})$ at $\mathrm{pH} 7.32$ (12.4 mg/L ferrous iron) and $+73.3 \mathrm{mV}$ at $\mathrm{pH} 6.81$ (14.0 mg/L ferrous iron). The following half-cell reaction was used to calculate Eh based on the $\mathrm{Fe}^{2+} / \mathrm{Fe}(\mathrm{OH})_{3}$ redox couple $\left(25^{\circ} \mathrm{C}\right)$ :

$$
\mathrm{Fe}(\mathrm{OH})_{3}+3 \mathrm{H}^{+}+\mathrm{e}^{-}=\mathrm{Fe}^{2+}+3 \mathrm{H}_{2} \mathrm{O}
$$

\section{Equation 2}

This redox couple is electrochemically reversible at concentrations of ferrous iron above $10^{-5}$ molal $(0.56 \mathrm{mg} / \mathrm{L})$ (Langmuir 1997, 56037) and may provide a partial control on Eh at well R-7 (screen \#3).

Concentrations of total (nonfiltered) iron detected within the regional aquifer ranged from 8.64 to $18.0 \mathrm{mg} / \mathrm{L}$ (Appendix A). Small differences between total and dissolved iron indicated that most of the total iron is stable as ferrous iron, which is probably derived from clay minerals and/or ferric (oxy)hydroxide, a solid phase that dissolves under reducing conditions in the presence of reductants (DOC and TOC).

Concentrations of natural iron within the regional aquifer exceeded both the EPA secondary standard for drinking water $(0.3 \mathrm{mg} / \mathrm{L})$ and the NMWQCC standard for water supply $(1.0 \mathrm{mg} / \mathrm{L})$ for all sampling rounds. Concentrations of manganese in the regional aquifer exceeded both the EPA secondary standard of $0.05 \mathrm{mg} / \mathrm{L}$ and the NMWQCC standard of $0.2 \mathrm{mg} / \mathrm{L}$ for domestic water supply for all sampling rounds. 
Concentrations of dissolved nickel ranged from 0.028 to $0.210 \mathrm{mg} / \mathrm{L}$ in the regional aquifer at well R-7 during characterization sampling. During drilling of the well, the dissolved concentration of nickel was $0.0022 \mathrm{mg} / \mathrm{L}$ in a groundwater sample collected at $902 \mathrm{ft}$ (Stone et al. 2002, 72717). Low concentrations of nickel $(<0.020 \mathrm{mg} / \mathrm{L})$ are typically observed at the Laboratory and around the Pajarito Plateau (ESP 2001, 71301). The NMWQCC standard (irrigation use) for dissolved nickel is $0.2 \mathrm{mg} / \mathrm{L}$, and the highest concentration of dissolved nickel was approximately $105 \%$ of the NMWQCC standard. The EPA primary standard for nickel is $0.1 \mathrm{mg} / \mathrm{L}$, and concentrations of nickel at R-7 exceeded the maximum contaminant level (MCL) during the first and second sampling rounds, on May 31, 2001, and August 9, 2001, respectively. Concentrations of nickel were below both the EPA and NMWQCC standards during the third and fourth sampling rounds, on October 26, 2001, and February 20, 2002, respectively.

The source of nickel observed in screen \#3 is not known. It seems unlikely that the nickel is anthropogenic because it was detected at only $0.0022 \mathrm{mg} / \mathrm{L}$ during drilling (Stone et al. 2002, 72717), and nickel concentrations decreased significantly during the third and fourth sampling rounds. One explanation for the elevated nickel concentrations observed in screen \#3 is that natural adsorbents such as $\mathrm{Fe}(\mathrm{OH})_{3}$ and $\alpha-\mathrm{FeOOH}$ present in the Puye Formation dissolved because of the reducing conditions that had stabilized near the well screens and nickel desorbed from the dissolving solids. The phases $\mathrm{Fe}(\mathrm{OH})_{3}$ and $\alpha-\mathrm{FeOOH}$ initially form from the hydrolysis of $\mathrm{Fe}_{2} \mathrm{O}_{3}, \mathrm{Fe}_{3} \mathrm{O}_{4}$, and possibly silica glass.

During drilling of well R-7, organic fluids were introduced for lubricity. They eventually oxidized and formed organic acids. Such oxidation results in reductive dissolution of $\mathrm{Fe}$ (III) and $\mathrm{Mn}$ (III and IV) solids; consequently, reducing conditions relative to manganese, iron, and sulfur are temporarily established. Desorption of nickel from dissolution of $\mathrm{Fe}(\mathrm{OH})_{3}$ in the presence of organic acids, for example acetate produced from oxidation of $E Z-M U D \circledR$ copolymer, is shown by the following equation:

$$
8\left(\equiv \mathrm{Fe}^{3+} \mathrm{O}^{2-} \mathrm{Ni}^{2+}\right)+7 \mathrm{H}^{+}+\mathrm{CH}_{3} \mathrm{COO}^{-}=8 \mathrm{Fe}^{2+}+8 \mathrm{Ni}^{2+}+2 \mathrm{HCO}_{3}^{-}+4 \mathrm{H}_{2} \mathrm{O}
$$

Equation 3

where:

$$
8\left(\equiv \mathrm{Fe}^{3+} \mathrm{O}^{2-} \mathrm{Ni}^{2+}\right) \text { is the adsorption surface site containing nickel. }
$$

Acetate has been identified as an oxidation product in the EZ-MUD® copolymer (Longmire 2002, 72613). Acetate is considered to be one of the electron donors (reducing agents) that enhances reduction of $\mathrm{Fe}(\mathrm{OH})_{3}$ and $\alpha-\mathrm{FeOOH}$ to aqueous $\mathrm{Fe}(\mathrm{II})$. Organic acids may have provided reductants to the regional aquifer at well R-7. This desorption process is discussed in more detail in Section 6.0, "Groundwater Geochemical Calculations."

Figure 5.1-4 shows log molality iron versus log molality nickel for well R-7. The two solutes correlate with each other, suggesting that dissolution of iron solids is related to elevated concentrations of dissolved nickel. Other natural adsorbents present in the Puye Formation may include $\mathrm{MnO}_{2}$ and $\mathrm{MnOOH}$, which dissolve under reducing conditions and release nickel to groundwater. Dissolved concentrations of iron and nickel decreased during characterization sampling, suggesting that well R-7 is re-equilibrating with the regional groundwater.

Dissolved arsenic at a concentration of $0.00579 \mathrm{mg} / \mathrm{L}(5.79 \mu \mathrm{g} / \mathrm{L})$ was measured during the fourth sampling round at well R-7 (screen \#3). Occurrence of this trace element could be related to reductive dissolution of ferric (oxy)hydroxide in the presence of residual drilling fluids at the well. Concentrations of measurable total arsenic ranged from 0.00348 to $0.00812 \mathrm{mg} / \mathrm{L}(3.48$ to $8.12 \mu \mathrm{g} / \mathrm{L})$ (Appendix A), suggesting that this trace element is associated with suspended material, most likely through adsorption processes. 


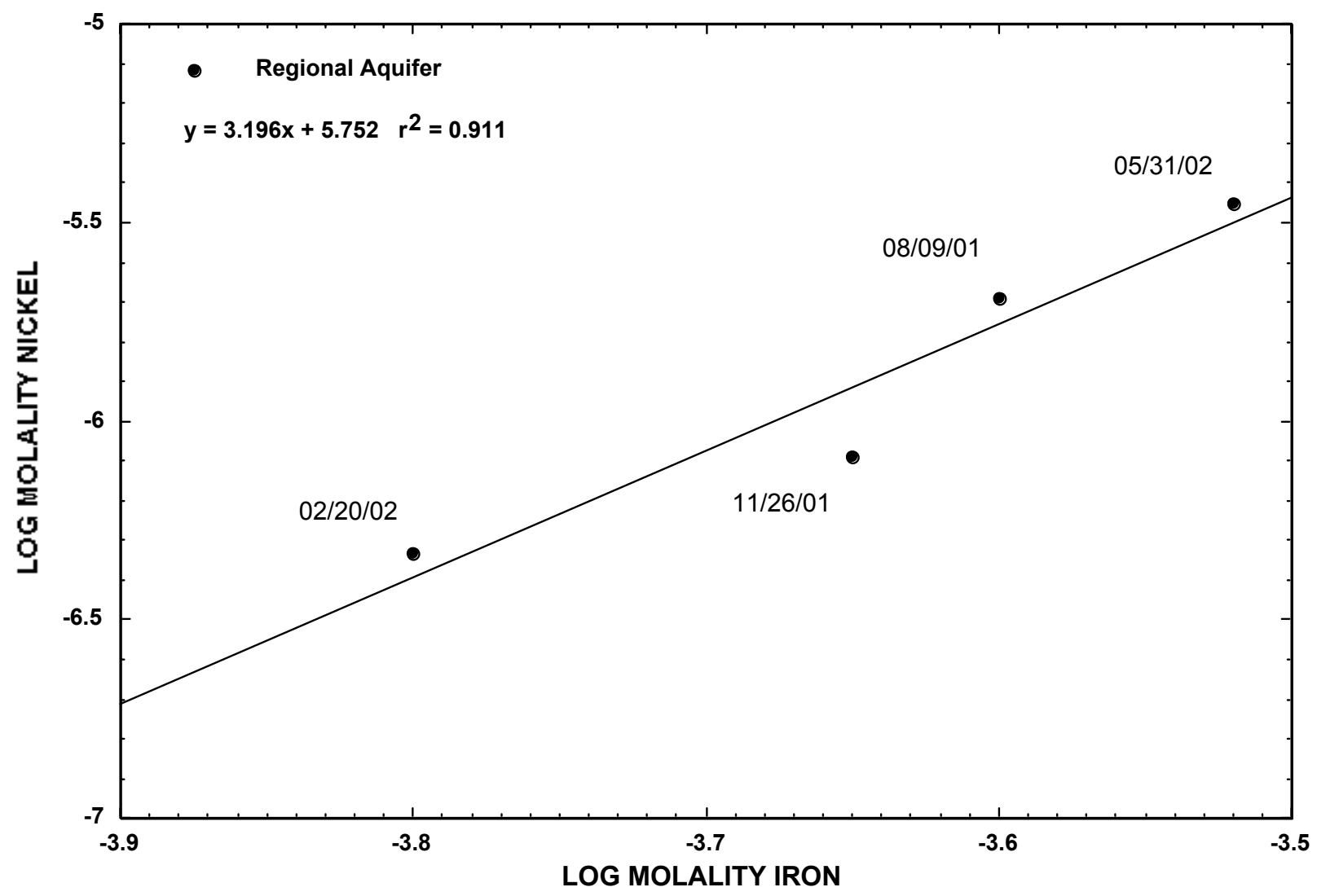

Figure 5.1-4. Log molality iron versus log molality nickel for well R-7 (915.0 ft), screen \#3

Concentrations of dissolved barium and strontium in the perched zone ranged from 0.056 to $0.084 \mathrm{mg} / \mathrm{L}$ and from 0.038 to $0.073 \mathrm{mg} / \mathrm{L}$, respectively (Table 5.1-1). Concentrations of dissolved barium and strontium within the regional aquifer ranged from 0.172 to $0.230 \mathrm{mg} / \mathrm{L}$ and from 0.092 to $0.160 \mathrm{mg} / \mathrm{L}$, respectively (Table 5.1-2). Concentrations of trace elements, including antimony (Sb), arsenic (As), barium $(\mathrm{Ba})$, beryllium $(\mathrm{Be})$, cadmium $(\mathrm{Cd})$, chromium $(\mathrm{Cr})$, cobalt $(\mathrm{Co})$, copper $(\mathrm{Cu})$, lead $(\mathrm{Pb})$, mercury $(\mathrm{Hg})$, molybdenum $(\mathrm{Mo})$, selenium $(\mathrm{Se})$, silver $(\mathrm{Ag})$, strontium $(\mathrm{Sr})$, thallium $(\mathrm{TI})$, uranium $(\mathrm{U})$, vanadium $(\mathrm{V})$, and zinc $(\mathrm{Zn})$, were within the low-to-moderate $\mu \mathrm{g} / \mathrm{L}$ range and were less than their respective EPA and NMWQCC standards.

Summaries of tritium distributions in precipitation, cold streams, groundwater and hot/cold springs of the Jemez Mountains region have been given by Vuataz and Goff (1986, 73687), Shevenell and Goff (1995, 73686), Adams et al. (1995, 47192), and Blake et al. (1995, 49931). Both perched and regional aquifer groundwater collected from well R-7 contain less tritium than the natural pre-bomb value of tritium in the waters of North America (19 $\pm 6 \mathrm{pCi} / \mathrm{L}$ [pCi//g H $\mathrm{H}_{2} \mathrm{O}$ ]; Kaufman and Libby 1954, 73688; Craig and Lal 1961, 73696). Well R-7 groundwater contained substantially less tritium than Jemez Mountains surface water of present age to about 35 years before present (Shevenell and Goff 1995, 73686). This finding indicates that most of the perched groundwater and the regional aquifer sampled from well R-7 is more than 35 years old. In addition, well R-7 groundwater contains a minor component of pre-bomb tritium that has mixed with native groundwater. Because of its short half-life (12.43 yr), tritium would not be detected in groundwater that predates atmospheric testing. However, because small activities of tritium were detected (1.34 to $3.38 \mathrm{pCi} / \mathrm{L})$, a minor component of young water $(<35 \mathrm{yr})$ is present. 
The four groundwater samples collected from the perched zone at well R-7 have a mean tritium activity of $3.0 \pm 0.4 \mathrm{pCi} / \mathrm{L}$ with no obvious trend in the data. Apparently, groundwaters of slightly different but variable age flow through the upper Puye Formation (screen \#1) of well R-7. In contrast, the four samples collected from the regional aquifer (screen \#3) in well R-7 have a mean tritium value of $1.8 \pm 0.5 \mathrm{pCi} / \mathrm{L}$, but the data showed a trend of decreasing tritium with the four sampling rounds. This trend suggests that the well is equilibrating with native groundwater. The last tritium value (fourth round) of $1.3 \mathrm{pCi} / \mathrm{L}$ tritium is probably most representative of the "true" tritium activity.

Determination of groundwater ages using tritium data assumes two end-member models for the calculations: piston-flow and well-mixed (Shevenell and Goff 1995, 73686). The two models bracket the "real" age of the fluid when the water types mix. Discussion of the models and their assumptions, derivation of the various equations, and evaluation of the input data for the Jemez Mountains region are presented in detail by Shevenell and Goff $(1995,73686)$. Tables of groundwater ages as functions of tritium content for sampling years are given in both Blake et al. $(1995,49931)$ and Shevenell and Goff $(1995,73686)$. Using the average tritium activity for the perched zone at well R-7, the piston-flow model yields an apparent age of roughly 55 years, and the well-mixed model yields an apparent age of roughly 2000 years. The erratic behavior of tritium in successive samples suggests that the piston-flow age is probably closest to the "true" age, particularly if mixing has occurred. In contrast, the last sample collected from the regional aquifer at well R-7 has a piston-flow age of roughly 65 years and a well-mixed age of roughly 4000 years. Because mixing of regional water with drilling fluids is highly likely in this zone, it is impossible to evaluate further the age of this zone.

Activities of selected radionuclides are provided in Tables 5.1-1 and 5.1-2. Americium-241, cesium-137, plutonium-238, plutonium-239,240, strontium-90, technetium-99, and uranium-235 were not detected in the groundwater samples collected from well R-7 (Appendix A). Gross alpha and gross beta activities were less than $5 \mathrm{pCi} / \mathrm{L}$ in several nonfiltered samples (Tables 5.1-1 and 5.1-2). Measurable gross gamma (122-181 pCi/L) was attributed to isotopes within the natural uranium-238, uranium-235, and thorium-232 decay chains (Langmuir 1997, 56037) (Tables 5.1-1 and 5.1-2). Activities of uranium-238 and uranium-234 were less than $0.1 \mathrm{pCi} / \mathrm{L}$ in groundwater samples collected from well R-7 (Tables 5.1-1 and 5.1-2). Similar activities of uranium were measured in supply wells during 2000 (ESP 2001, 71301).

Analyses of $\delta \mathrm{D}$ and $\delta^{18} \mathrm{O}$ were performed on groundwater samples collected from well R-7 (Tables 5.1-1 and 5.1-2) and average results are shown in Figure 5.1-5. Stable isotope ratios for other R-wells and from other locations in the Jemez Mountains region (Vuataz and Goff 1986, 73687; Blake et al. 1995, 49931) are also shown in Figure 5.1-5. Wells R-5, R-9i, and R-12 drilled in Pueblo Canyon, Los Alamos Canyon, and Sandia Canyon, respectively, have screens set in perched zones within the Cerro del Rio lavas. Well R-25 was drilled in TA-16 and contains an upper saturated zone several hundred feet thick (Broxton et al. 2002, 72640). Perched groundwater samples from wells R-5, R-7, R-9i, R-12, and R-25 (Figure 5.1-5) show a significant spread of values $\left(-85\right.$ to $-70 \%$ o $\mathrm{D}$ and -12 to $-10.5 \%$ o $\left.\delta^{18} \mathrm{O}\right)$ that parallels the World Meteoric Water Line (MWL) of Craig and Lal $(1961,73696)$ and the Jemez Mountains Meteoric Water Line (JMML) of Vuataz and Goff $(1986,73687)$.

Regional aquifer groundwater at wells $\mathrm{R}-5, \mathrm{R}-7, \mathrm{R}-9, \mathrm{R}-12$, and $\mathrm{R}-15$ show a smaller range of values (-80 to $-70 \%$ $\delta \mathrm{D}$ and -11.3 to $-10.4 \% \delta^{18} \mathrm{O}$ ) that is skewed to "heavier" (less depleted) isotope values relative to perched waters described above (Figure 5.1-5). The spread of isotopic values in each case is consistent with a correlation between higher recharge elevations and higher wellhead elevations, suggesting that wells closer to the Sierra de los Valles have slightly higher recharge elevations than wells closer to the Rio Grande. 

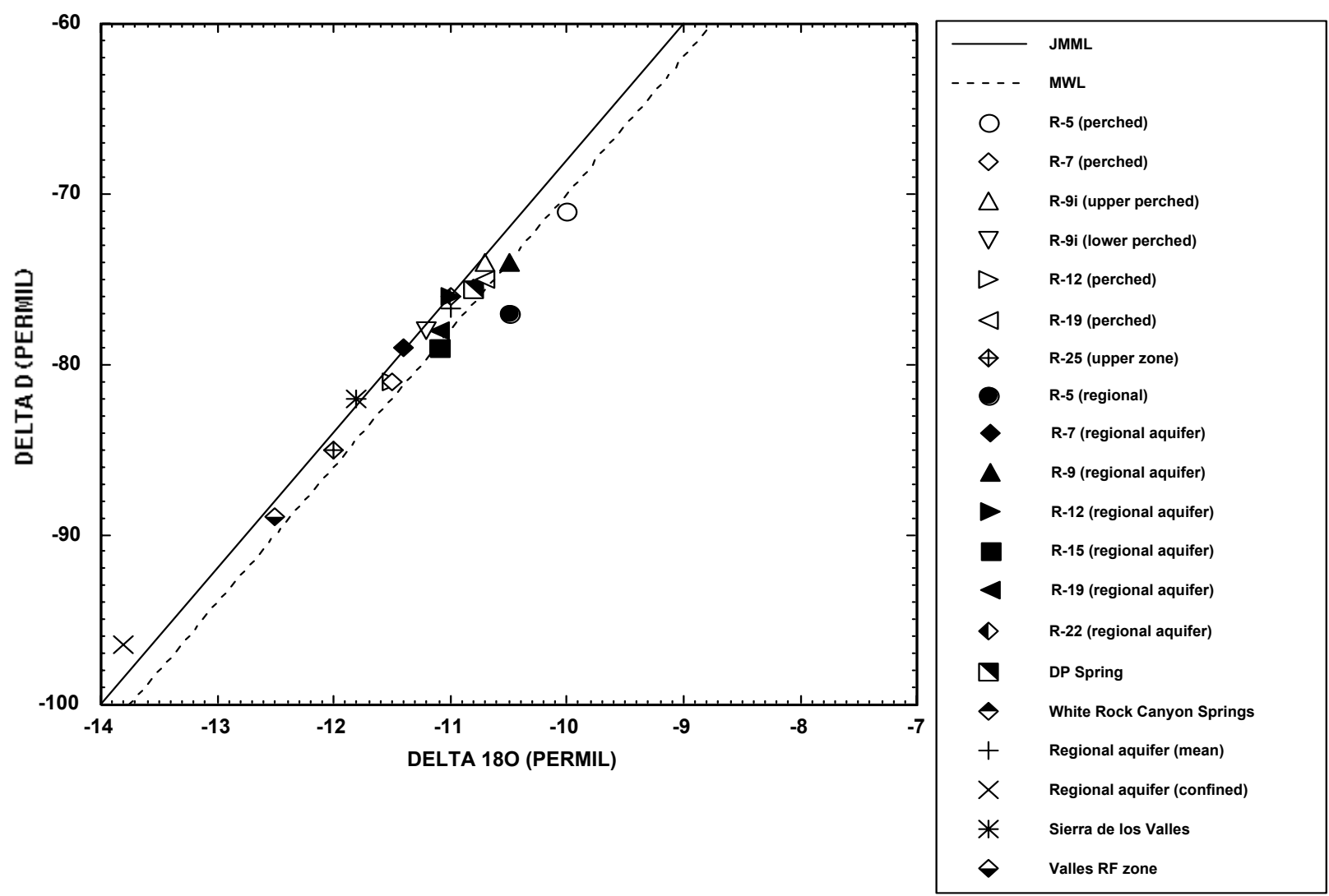

Figure 5.1-5. Average stable isotope results for wells R-5, R-7, R-9i, R-12, R-15, R-19, R-22, R-25, White Rock Canyon Springs, regional aquifer, DP Spring, Sierra de los Valles, Valles ring fracture zone, and "confined aquifer"

Average stable isotope ratios for other groundwater samples, shown in Figure 5.1-5, include DP spring ( $n=22$, Blake et al. 1995, 49931); White Rock Canyon springs ( $n=32$, Blake et al. 1995, 49931); Guaje Canyon and Pajarito Plateau well fields ( $n=30$, Blake et al. 1995, 49931); Sierra de los Valles springs ( $n=8$, Vuataz and Goff, 1986, 73687, and Blake et al. 1995, 49931); Valles ring fracture zone $(n=17$, Vuataz and Goff, 1986, 73687); and "confined regional aquifer" ( $n=28$, Blake et al. 1995, 49931). The perched zone and regional aquifer at well R-7 were characterized by similar $\delta \mathrm{D}$ and $\delta^{18} \mathrm{O}$ ratios (Figure 5.1-5). They are isotopically enriched relative to average Sierra de los Valles waters $(n=8)$ but more depleted than average DP spring water, average White Rock Canyon spring waters, and average regional aquifer groundwater (Vuataz and Goff 1986, 73687; Blake et al. 1995, 49931). Well R-7 groundwater is considerably less depleted than average Valles caldera ring fracture zone waters and average "confined aquifer" waters. Figure 5.1-5 indicates that the most likely source of recharge for R-7 groundwater is from the Sierra de los Valles to the west.

Figure 5.1-5 also shows the strong isotopic gradients observed in the Jemez Mountains region relative to elevation differences; higher elevation sites have consistently more depleted isotope values (Hoefs 1973, 73685; Clark and Fritz 1997, 59168). These data indicate that, on average, different water types in the Jemez Mountains and the Pajarito Plateau have isotope values that are greatly influenced by their average recharge elevations. 
The one exception to this rule is the group of waters from the "confined aquifer" (the regional aquifer) near San Ildefonso Pueblo (confined aquifer as originally defined by Purtymun and Johansen 1974, 11835; see also Blake et al. 1995, 49931). This groundwater discharges at elevations similar to the White Rock Canyon springs, yet its average isotope values are exceptionally depleted (Goff and Sayer 1980, 73686). The "confined aquifer" groundwater is so completely different in isotopic composition that it must be recharged from entirely different high elevation sources than other Jemez Mountains region waters. Goff and Sayer $(1980,73686)$ originally proposed that the source might be from the Sangre de Cristo Range east of the Pajarito Plateau.

Nitrogen isotopes (nitrogen-15 and nitrogen-14, $\delta^{15} \mathrm{~N}_{\mathrm{AIR}}-\mathrm{NO}_{3}$ and $\delta^{15} \mathrm{~N}_{\mathrm{AIR}}-\mathrm{NH}_{3}$ ) provide a useful tool for evaluating different sources of nitrogen (nitrate plus nitrite and ammonium) found in the environment. The isotopic standard for $\delta^{15} \mathrm{~N}$ is nitrogen in air, which has a value of $0 \%$ (Clark and Fritz 1997, 59168). Nitrate derived from treated septic effluent is enriched in nitrogen-15 or depleted in nitrogen-14 and is characterized by positive $\delta^{15} \mathrm{~N}$ ratios of +7 to $>+30 \%$ (Clark and Fritz 1997, 59168; Longmire 2002, 72800). During denitrification, which is the reduction of nitrate to nitrogen gas in the presence of organic carbon, residual nitrate becomes enriched in nitrogen-15. Subsequently, $\delta^{15} \mathrm{~N}$ ratios for nitrite become more positive with increasing denitrification.

Groundwater samples collected from screens \#1 and \#3 at well R-7 were analyzed for $\delta^{15} \mathrm{~N}_{\mathrm{AIR}}-\mathrm{NO}_{3}$, with results ranging from +0.9 to $+3.3 \%$ (Tables $5.1-1$ and $5.1-2$ ). These ratios fell within the range of volcanic deposits reported by Clark and Fritz $(1997,59168)$. The positive isotopic values measured in groundwater samples collected from 378.0 and $915.0 \mathrm{ft}$ suggest slight enrichment of nitrogen-15. The range of $\delta^{15} \mathrm{~N}_{\text {AIR- }}$ $\mathrm{NO}_{3}$ ratios at well R-7 showed very slight fractionation of nitrogen (increasing positive isotopic ratios), possibly resulting from denitrification. This finding implies that biochemical reactions control the distribution of nitrogen at this well. Concentrations of nitrate plus nitrite (as $\mathrm{N}$ ) in the perched zone ranged from 0.10 to $0.27 \mathrm{mg} / \mathrm{L}$ and are similar to natural nitrate plus nitrite (as $\mathrm{N}$ ) measured in supply wells on the Pajarito Plateau (ESP 2000, 68661, and ESP 2001, 71301). Concentrations of ammonium (as N) were less than detection in some samples, and it was not possible to measure $\delta{ }^{15} \mathrm{~N}_{\mathrm{AIR}}-\mathrm{NH}_{3}$ in groundwater samples because of limited sample volume.

Several VOCs and SVOCs (validated results) were detected at well R-7, including acetone (5.6 to $51 \mu \mathrm{g} / \mathrm{L})$, benzoic acid $(13 \mu \mathrm{g} / \mathrm{L})$, methylene chloride $(4.4 \mu \mathrm{g} / \mathrm{L})$, phenol $(11 \mu \mathrm{g} / \mathrm{L})$, isopropylbenzene $(0.55$ to $0.94 \mu \mathrm{g} / \mathrm{L})$, N-nitrosodiphenylamine $(9.6 \mu \mathrm{g} / \mathrm{L}), 4,4^{\prime}-\mathrm{DDT}(0.0077 \mu \mathrm{g} / \mathrm{L})$, and 4-methylphenol (1.8 and $58 \mu \mathrm{g} / \mathrm{L}$ ) (Appendix A). Laboratory blanks did not contain any VOCs, which suggests that meaningful and accurate analytical results for volatile organic compounds were provided. Methylene chloride is a laboratory solvent used during SVOC, pesticide and polychlorinated biphenyls (PCB) analyses using gas chromatography mass spectrometry (GCMS) and gas chromatography with an electron-capture detector. Bis(2-ethylhexyl)phthalate, a constituent of plastic, was detected at concentrations of $18.7 \mu \mathrm{g} / \mathrm{L}$ in the regional aquifer during the first and fourth sampling events (Appendix A). Additional sampling for VOCs and SVOCs is recommended at well R-7 to determine the long-term presence of these chemicals, which are possibly false positives produced by residual drilling fluid.

The occurrence of acetone at well R-7 can be regarded as a false positive for several reasons. QUIKFOAM® used during drilling consists of isopropyl alcohol, which has a molecular weight of 60.1 atomic mass units (amu). Acetone has a mass of $58.08 \mathrm{amu}$, which is very similar to that of isopropyl alcohol. These compounds will elute in nearly the same retention time on a typical GC/MS system following SW-846 Method 8260. The mass units for isopropyl alcohol are (mass/charge, m/z) 45, 43, 59, and 58, and the mass units for acetone are 43 and 58. For qualification purposes, the mass spectrometer uses the mass units and retention time. The analyte must elute in a certain retention-time window and have the correct corresponding mass units for identification. Because of the similar retention times and 
mass units for both acetone and isopropyl alcohol, these two compounds can be misidentified. This explanation is supported by the mass spectra data. Acetone can be misidentified because the secondary ion for isopropyl alcohol is 43 , which is the primary ion for acetone. This misidentification also occurred in groundwater samples collected from wells R-12, R-19, and R-22.

Analysis of the DOC fractionation (also termed "humic substances"), including both hydrophobic and hydrophilic fractions, was performed on four groundwater samples (screens \#1 and \#3) collected during the first, third, and fourth events (Appendix A). Both fractions contained acid-, neutral-, and base-organic substances. Hydrophobic acids include humic and fulvic acids (carboxylic acids and phenols), whereas the hydrophobic neutral fraction includes aliphatic organic compounds (Vilks and Bachinski 1996, 71515). Hydrophobic bases include aromatic amines and other nitrogen-containing compounds. The hydrophilic fraction contains low-molecular weight (5 carbon atoms) polyelectrolytic and aliphatic acids (acid fraction), aliphatic amines and amino acids (base fraction), and alcohols, esters, aliphatic amides, and carbohydrates (neutral fraction) (Vilks and Bachinski 1996, 71515). These two DOC fractions occur naturally in groundwater (Vilks and Bachinski 1996, 71515) with a median concentration of $0.7 \mathrm{mgC/L}$ (Thurman 1985, 71514). Anthropogenic sources, including refined petroleum products, drilling fluids, and high-molecular weight organic compounds, are also possible.

A DOC concentration of $2.2 \mathrm{mgC} / \mathrm{L}$ was measured in a groundwater sample collected from the screen \#1 (perched zone, upper Puye Formation) at a depth of $378.0 \mathrm{ft}$ on May 30, 2001. This sample contained $1.5 \mathrm{mgC} / \mathrm{L}$ hydrophobic fraction consisting of $1.0 \mathrm{mgC} / \mathrm{L}$ acid fraction, $0.5 \mathrm{mgC} / \mathrm{L}$ neutral fraction, and less than $0.1 \mathrm{mgC} / \mathrm{L}$ base fraction. The neutral fraction consisted of short-chain aliphatic compounds as breakdown products of the EZ-MUD® copolymer. The groundwater also contained $0.7 \mathrm{mgC} / \mathrm{L}$ hydrophilic fraction, which consisted of $0.3,0.4$, and $<0.1 \mathrm{mgC} / \mathrm{L}$ acid, neutral, and base fractions, respectively. The base fraction consisted of amino acids and other nitrogen-related compounds characteristic of EZ-MUD $\mathbb{\text { . }}$

A DOC concentration of $8.3 \mathrm{mgC} / \mathrm{L}$ was measured in a groundwater sample collected from the screen \#3 (regional aquifer, lower Puye Formation) at a depth of $915.0 \mathrm{ft}$ on May 31, 2001. This sample contained $4.2 \mathrm{mgC} / \mathrm{L}$ hydrophobic fraction consisting of $2.5 \mathrm{mgC} / \mathrm{L}$ acid fraction, $1.6 \mathrm{mgC} / \mathrm{L}$ neutral fraction, and $0.1 \mathrm{mgC} / \mathrm{L}$ base fraction. The groundwater also contained $4.1 \mathrm{mgC} / \mathrm{L}$ hydrophilic fraction, which consisted of $2.3,1.9$, and $<0.1 \mathrm{mgC} / \mathrm{L}$ acid, neutral, and base fractions, respectively.

Approximately $35.4 \%$ of the humic and fulvic acids (hydrophobic acid fraction in the regional aquifer at $915.0 \mathrm{ft}$ ) were calculated to form a complex with calcium (see Table 6.2-1). Analytical results for a groundwater sample collected from the regional aquifer on May 31, 2001, were used for this speciation calculation. The majority of humic and fulvic acids were stable as noncomplexed anions. Formation of calcium-humate and/or calcium-fulvate complexes did not influence the stability of $\mathrm{CaCO}_{3}$ (calcite) according to MINTEQA2 simulations. The origin of DOC in groundwater at well R-7 includes natural sources and/or residual fluids from drilling and/or well completion. The neutral and base fractions may consist of residual EZ-MUD® copolymer and aliphatic compounds.

A DOC concentration of $4.0 \mathrm{mgC} / \mathrm{L}$ was measured in a groundwater sample collected from the screen \#3 on November 26, 2001. This sample contained $2.0 \mathrm{mgC} / \mathrm{L}$ hydrophobic fraction consisting of $0.9 \mathrm{mgC} / \mathrm{L}$ acid fraction, $0.9 \mathrm{mgC} / \mathrm{L}$ neutral fraction, and $0.2 \mathrm{mgC} / \mathrm{L}$ base fraction. The groundwater also contained $2.0 \mathrm{mgC} / \mathrm{L}$ hydrophilic fraction, which consisted of $1.6,0.4$, and $<0.1 \mathrm{mgC} / \mathrm{L}$ acid, neutral, and base fractions, respectively.

A final DOC concentration of $3.2 \mathrm{mgC} / \mathrm{L}$ was measured in a groundwater sample collected from the screen \#3 on February 20,2002 . This sample contained $1.5 \mathrm{mgC} / \mathrm{L}$ hydrophobic fraction consisting of $0.7 \mathrm{mgC} / \mathrm{L}$ acid fraction, $0.8 \mathrm{mgC} / \mathrm{L}$ neutral fraction, and $<0.1 \mathrm{mgC} / \mathrm{L}$ base fraction. The groundwater also contained $1.7 \mathrm{mgC} / \mathrm{L}$ hydrophilic fraction, which consisted of $1.4,0.2$, and $0.1 \mathrm{mgC} / \mathrm{L}$ acid, neutral, and 
base fractions, respectively. Concentrations of DOC and associated acid, neutral, and base fractions decreased during characterization sampling at well R-7 as residual EZ-MUD® oxidized to inorganic carbon.

\subsection{Comparison to Wells R-7, R-9, R-9i, R-12, R-15, R-19, and R-22}

Wells R-9, R-12 (screen \#3), R-15, R-19 (screens \#3 through \#7), and R-22 are completed at the regional water table and provide a comparison for water chemistry with well R-7 (screen \#3). Wells R-9, R-12, $\mathrm{R}-15$, and R-22 contain measurable tritium between 2 and $83 \mathrm{pCi} / \mathrm{L}$ in the regional aquifer (Longmire 2002, 72713; Longmire 2002, 72800; Longmire 2002, 72714; and Longmire 2002, 73676). The highest activities of tritium in the regional aquifer were measured in well R-12 and the lowest in R-22 (screen \#1). Tritium was not detected at well R-19 (Longmire 2002, 73282). The detection of tritium (less than $3 \mathrm{pCi} / \mathrm{L}$ in the regional aquifer) suggests that the regional aquifer at well $\mathrm{R}-7$ has experienced some recharge from the surface in the past 35 years. Activities of tritium less than $4 \mathrm{pCi} / \mathrm{L}$ were measured in the perched zone at well R-7 and are much lower than those measured in perched zones at wells R-9i and R-12 (screens \#1 and \#2). Potential sources of tritium include a combination of atmospheric fallout, natural, and local sources (Sierra de los Valles and/or the Laboratory).

Elevated concentrations of natural iron, nickel, and/or manganese that occur in wells R-7, R-9i, R-12, $\mathrm{R}-19$, and $\mathrm{R}-22$ are caused by oxidation-reduction reactions involving residual drilling fluids. These wells, however, are re-equilibrating with groundwater, and concentrations of these constituents generally decreased during characterization sampling. Concentrations of other trace elements and trace metals observed at well R-7 were within the ranges for samples collected from wells R-9 and R-9i (Longmire 2002, 72713), R-12 (Longmire 2002, 72800), R-15 (Longmire 2002, 72614), R-19 (Longmire 2002, 73282), and R-22 (Longmire 2002, 73676).

\subsection{GROUNDWATER GEOCHEMICAL CALCULATIONS}

\subsection{Computer Program Selection}

Results of geochemical calculations suggest that groundwater chemistry and mineral stability are evolving at well R-7 as residual drilling fluid breaks down. Equilibrium conditions should be re-established after the residual drilling fluid has been removed from the well. Geochemical calculations of groundwater samples collected from well R-7 (screens \#1 and \#3) were conducted to evaluate speciation of solutes (dissolved species), to quantify adsorption reactions with nickel and ferric (oxy)hydroxide, and to quantify the state of saturation of solid phases that control groundwater composition under equilibrium conditions. These calculations provide insight into processes that control water/rock interactions, including mineral precipitation and adsorption occurring in both natural and contaminated water. Geochemical processes influence natural water composition, dissociation of residual drilling fluids, and contaminant chemistry and transport.

Calculations of solute speciation, $\mathrm{PCO}_{2}$ gas, adsorption, and solid-phase saturation indices were made using the computer program MINTEQA2 (Allison et al. 1991, 49930), with single-ion activity coefficients calculated using the Davies equation. MINTEQA2 was developed by Battelle Northwest for the EPA for use at RCRA and Superfund sites. The model is constrained by solute concentrations and involves silicate, glass, ferric oxide, and clay minerals identified by Stone et al. $(2002,72717)$ at well R-7. MINTEQA2 quantifies possible rock/water and water/atmosphere reactions, but modeling results should be interpreted with caution and are limited by the scope of our understanding of hydrologic flow conditions (saturated and unsaturated), possible reaction mechanisms, and kinetic constraints in a disequilibriumdominated system. One source of error in using the computer program is the accuracy of the chemical 
thermodynamic data contained in the database. Errors are greater for trace solutes for which experimental data are inaccurate and/or incomplete, including thallium, beryllium, and cadmium. The uranium database contained in MINTEQA2 has been critically evaluated by Grenthe et al. $(1992,71511)$. Fewer errors are associated with the major ions and with solid phases consisting of carbonate, silicate, and ferric (oxy)hydroxide (Langmuir 1997, 56037).

\subsection{Speciation Calculations}

Speciation calculations using the computer program MINTEQA2 (Allison et al. 1991, 49930) were performed to evaluate stable forms of dissolved solutes, which influence mineral precipitation and adsorption reactions occurring in natural and contaminated waters. Fate and transport of natural iron, nickel, and manganese at well R-7 are controlled by both aqueous speciation and adsorption/desorption processes. Input files for the calculations are provided in Appendix B. Solutes of importance at well R-7 included major ions, nickel, iron, and manganese.

Results of the speciation calculations for groundwater samples collected from screen \#3 are provided in Table 6.2-1. Ferrous iron is predicted to be stable as dissolved $\mathrm{Fe}^{2+}$, and the hydrolysis species $\mathrm{FeOH}^{+}$is a minor component (not shown in Table 6.2-1). The free or uncomplexed $\mathrm{Fe}^{2+}$ cation is available for adsorption and precipitation reactions. Concentrations of dissolved iron in the regional aquifer at well R-7 varied depending on the presence of chemical reductants such as TOC and DOC associated with residual drilling fluids (Table 5.1-2). Nickel is predicted to be stable as $\mathrm{NiCO}_{3}{ }^{0}$ and $\mathrm{Ni}^{2+}$, and above $\mathrm{pH}$ values greater than 8.5 , the free (noncomplex) cation is predicted to adsorb onto negatively charged surface sites on $\mathrm{Fe}(\mathrm{OH})_{3}$ to a greater extent than the ion pair. Uranium(IV) is predicted to be stable as $\mathrm{U}(\mathrm{OH})_{4}{ }^{0}$ in the presence of residual drilling fluid, and this hydrolysis species is semisorbing onto mineral surfaces and enhances the precipitation of amorphous $\mathrm{UO}_{2}, \mathrm{UO}_{2}$, and $\mathrm{USiO}_{4}($ Langmuir 1997, 56037).

Arsenic was detected in screen \#3 at a concentration of $0.00579 \mathrm{mg} / \mathrm{L}(5.79 \mu \mathrm{g} / \mathrm{L})$ during the fourth sampling round. Arsenic is stable in both the III and V oxidation states in aqueous solutions, forming oxyanions and neutral species. The source of arsenic at well R-7 is unknown; however, the occurrence of arsenic could be related to the reductive dissolution of ferric (oxy)hydroxide resulting in desorption of arsenic species. This dissolution is enhanced under reducing conditions characterized by elevated DOC, iron, and manganese. Under oxidizing conditions, arsenic (III and V) adsorbs onto ferric (oxy)hydroxide, with $\mathrm{As}(\mathrm{V})$ adsorbing more strongly than As(III) (Langmuir 1997, 56037). As groundwater adjacent to screen \#3 reoxidizes, ferric (oxy)hydroxide should reprecipitate and arsenic complexes should readsorb.

Concentrations of total and dissolved uranium are less than $1 \mu \mathrm{g} / \mathrm{L}$ at well $\mathrm{R}-7$. Uranium(VI) is predicted to be stable as $\mathrm{UO}_{2}(\mathrm{OH})_{2}{ }^{0}, \mathrm{UO}_{2} \mathrm{CO}_{3}{ }^{0}, \mathrm{UO}_{2}\left(\mathrm{CO}_{3}\right)_{2}{ }^{2-}$, and $\mathrm{UO}_{2}\left(\mathrm{CO}_{3}\right)_{3}{ }^{4-}$ under oxidizing conditions characteristic of the perched zone (screen \#1). These conditions are indicated by low concentrations of iron and manganese and the presence of dissolved oxygen. Uranyl carbonato (anionic) complexes are poorly to semisorbing onto hydrous ferric oxide between a $\mathrm{pH}$ range of 5.0 and 7.0, depending upon carbonate concentration (Langmuir 1997, 56037). Uranium(IV) is predicted to be stable as $\mathrm{U}(\mathrm{OH})_{4}{ }^{0}$ in the presence of TOC and DOC above $1 \mathrm{mgC} / \mathrm{L}$ and under sulfate-reducing conditions (sulfate concentrations less than detection) in screen \#3. Prior to drilling of well R-7, $U(\mathrm{VI})$ complexes are believed to be stable in the absence of reductants such as DOC and hydrogen sulfide.

Manganese is predicted to be stable as $\mathrm{Mn}^{2+}$ in the regional aquifer (screen \#3) (not shown in Table 6.2-1). Increasing concentrations of natural manganese occur in the regional aquifer and correlate well with iron. Major ions consisting of $\mathrm{Ca}^{2+}, \mathrm{Mg}^{2+}, \mathrm{Na}^{+}, \mathrm{K}^{+}, \mathrm{Cl}^{-}, \mathrm{SO}_{4}{ }^{2-}$, and $\mathrm{HCO}_{3}{ }^{-}$(not shown in Table 6.2-1) are calculated to be stable as free or uncomplexed solutes at well R-7. Dissolved organic matter (DOM), consisting of humic and fulvic acids (hydrophobic acid fraction), is calculated by MINTEQA2 to include mainly noncomplexed solutes and a calcium-DOM complex (Table 6.2-1). 
Table 6.2-1

Results of Speciation Calculations Using MINTEQA2 for Well R-7 (screen \#3, $915.0 \mathrm{ft}$ ), Upper Los Alamos Canyon

\begin{tabular}{|c|c|c|c|}
\hline Solute & Dominant Speciation & Percentage & Sample Date (mo/dy/yr) \\
\hline $\mathrm{DOM}^{*}$ & $\mathrm{DOM}$ & 63.0 & $05 / 31 / 01$ \\
\hline $\mathrm{DOM}$ & $\mathrm{Ca}-\mathrm{DOM}$ & 35.4 & $05 / 31 / 01$ \\
\hline $\mathrm{DOM}$ & $\mathrm{Mg-DOM}$ & 1.3 & $05 / 31 / 01$ \\
\hline $\mathrm{Ni}(\mathrm{II})$ & $\mathrm{NiCO}_{3}{ }^{0}$ & 77.3 & $05 / 31 / 01$ \\
\hline $\mathrm{Ni}(\mathrm{II})$ & $\mathrm{Ni}^{2+}$ & 18.5 & $05 / 31 / 01$ \\
\hline $\mathrm{Ni}(\mathrm{II})$ & $\mathrm{NiHCO}_{3}{ }^{+}$ & 4.1 & $05 / 31 / 01$ \\
\hline $\mathrm{Ni}(\mathrm{II})$ & $\mathrm{NiCO}_{3}{ }^{2}$ & 71.3 & $08 / 09 / 01$ \\
\hline $\mathrm{Ni}(\mathrm{II})$ & $\mathrm{Ni}^{2+}$ & 23.9 & $08 / 09 / 01$ \\
\hline $\mathrm{Ni}(\mathrm{II})$ & $\mathrm{NiHCO}_{3}{ }^{+}$ & 4.7 & $08 / 09 / 01$ \\
\hline $\mathrm{Ni}(\mathrm{II})$ & $\mathrm{NiCO}_{3}{ }^{2}$ & 87.0 & $11 / 26 / 01$ \\
\hline $\mathrm{Ni}(\mathrm{II})$ & $\mathrm{Ni}^{2+}$ & 10.9 & $11 / 26 / 01$ \\
\hline $\mathrm{Ni}(\mathrm{II})$ & $\mathrm{NiHCO}_{3}{ }^{+}$ & 1.8 & $11 / 26 / 01$ \\
\hline $\mathrm{Ni}(\mathrm{II})$ & $\mathrm{NiCO}_{3}{ }^{2}$ & 87.4 & $02 / 20 / 02$ \\
\hline $\mathrm{Ni}(\mathrm{II})$ & $\mathrm{Ni}^{2+}$ & 10.3 & $02 / 20 / 02$ \\
\hline $\mathrm{Ni}(\mathrm{II})$ & $\mathrm{NiHCO}_{3}{ }^{+}$ & 1.9 & $02 / 20 / 02$ \\
\hline $\mathrm{As}(\mathrm{V})$ & $\mathrm{H}_{2} \mathrm{AsO}_{4}{ }^{-}$ & 21.0 & $02 / 20 / 02$ \\
\hline $\mathrm{As}(\mathrm{V})$ & $\mathrm{HAsO}_{4}{ }^{2-}$ & 79.0 & $02 / 20 / 02$ \\
\hline $\mathrm{As}(\mathrm{III})$ & $\mathrm{H}_{3} \mathrm{AsO}_{3}{ }^{0}$ & 99.2 & $02 / 20 / 02$ \\
\hline
\end{tabular}

${ }^{*} \mathrm{DOM}=$ dissolved organic matter.

Results of speciation calculations showed that cationic trace metals (iron and manganese) were stable in regional aquifer groundwater. As oxidizing conditions become re-established, iron and manganese are potentially removed from solution by precipitation, cation exchange, and adsorption (surface complexation) under circumneutral $\mathrm{pH}$ conditions.

\subsection{Saturation Index Calculations}

Solid-solution phase calculations were performed with MINTEQA2 (Allison et al. 1991, 49930) using analytical results (screens \#1 and \#3) obtained from filtered (less than $0.45 \mu \mathrm{m}$ membrane) groundwater samples. These calculations were used to assess the importance of precipitation reactions for controlling the transport of iron, nickel, manganese, uranium, and other solutes at well R-7.

Figure 6.3-1 shows the values of the saturation index (SI) for several key phases for well R-7 in the upper Puye Formation (378.0 ft). The $\mathrm{SI}$ is a measure of the degree of saturation, undersaturation, or oversaturation of a solid phase in water $\left(\mathrm{SI}=\log _{10}\right.$ \{activity product/solubility product\}; at equilibrium $\mathrm{SI}=$ $0 \pm 0.05$ ) (Langmuir 1997, 56037). Groundwater samples collected from screen \#1 were calculated to be undersaturated with respect to $\mathrm{BaSO}_{4}$ (barite), $\mathrm{CaCO}_{3}$ (calcite), $\mathrm{MnCO}_{3}$ (rhodochrosite), $\mathrm{SrCO}_{3}$ (strontianite), and amorphous silica precipitate (Figure 6.3-1). Groundwater was calculated to be in equilibrium or slightly oversaturated with respect to silica gel. 


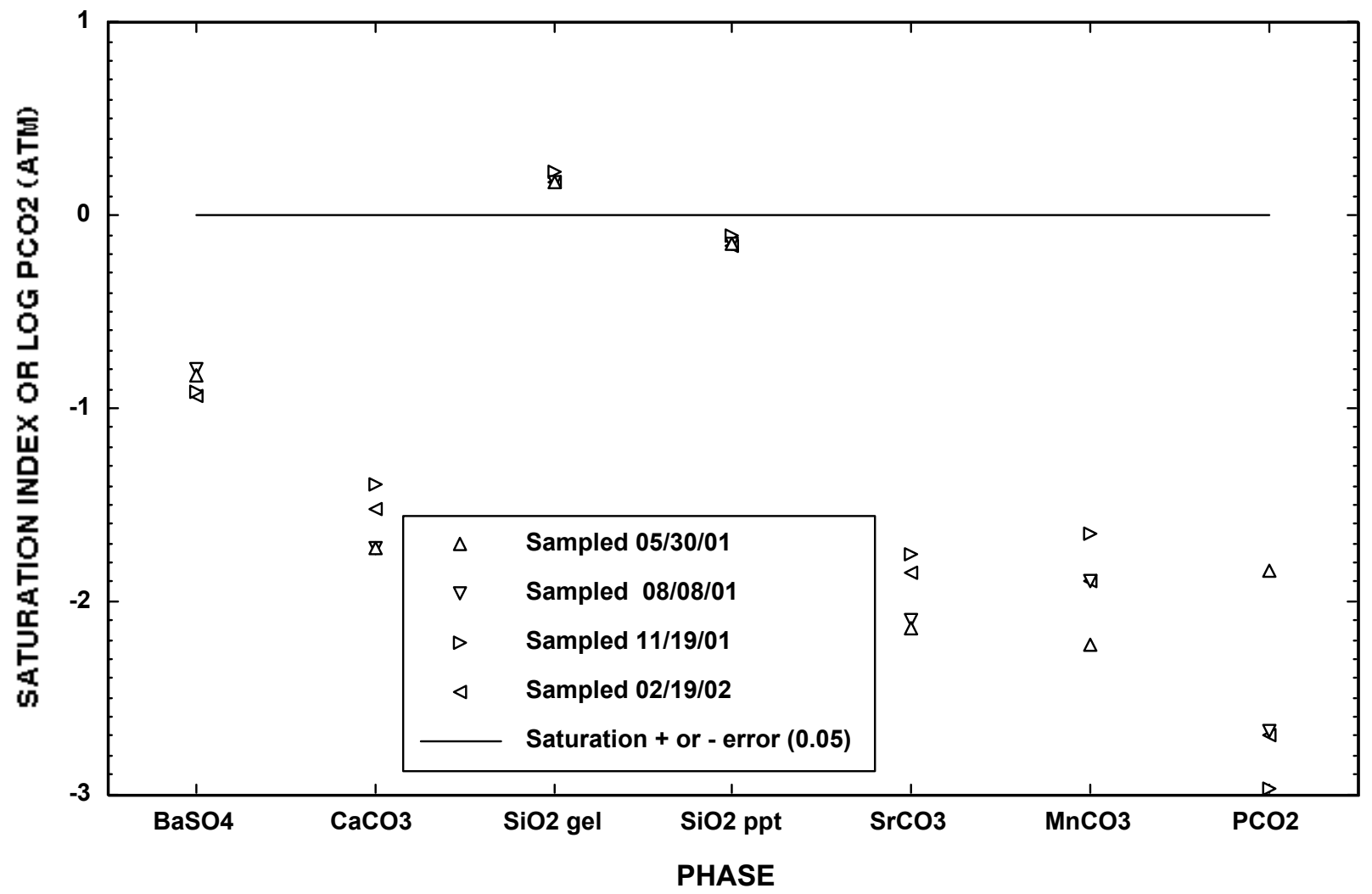
Figure 6.3-1. Results of saturation index calculations using MINTEQA2 for well R-7 (perched
zone, $378.0 \mathrm{ft}$ )

These results are generally consistent with observed mineralogy (i.e., the absence of strontium carbonate and the presence of silica glass) in the upper Puye Formation at well R-7. Calculated $\log _{10} \mathrm{PCO}_{2}$ gas varies from -2.79 to -1.84 atmosphere for R-7 groundwater (screen \#1), which is controlled by temperature, $\mathrm{pH}$, and alkalinity (natural and oxidation of drilling fluids). Variation in the SI values for $\mathrm{CaCO}_{3}$ and $\mathrm{SrCO}_{3}$ is the result of differing temperature, carbonate alkalinity, $\mathrm{pH}$, and activities of iron, calcium, and strontium in the groundwater.

Results of mineral saturation calculations for well R-7 (regional aquifer, lower Puye Formation) are shown in Figure 6.3-2 using analytical results for groundwater samples collected at $915.0 \mathrm{ft}$. The regional aquifer at well R-7 was calculated to be undersaturated with respect to $\mathrm{BaSO}_{4}, \mathrm{CaCO}_{3}$, silica precipitate, and $\mathrm{SrCO}_{3}$ (Figure 6.3-2). The regional aquifer was calculated to be undersaturated with respect to $\mathrm{Ni}(\mathrm{OH})_{2}$ and $\mathrm{NiCO}_{3}$, suggesting that adsorption/desorption processes control the transport of nickel at well R-7. Groundwater was calculated to be oversaturated with respect to silica gel, $\mathrm{FeCO}_{3}$ (siderite), and $\mathrm{USiO}_{4}$, (Figure 6.3-2). Groundwater showed variable saturation with respect to $\mathrm{MnCO}_{3}$. Calculated $\log _{10} \mathrm{PCO}_{2}$ gas varies from -2.32 to -1.73 atmosphere for R-7 groundwater (screen \#3).

Because of varying $\mathrm{pH}$, alkalinity, temperature, and concentrations of calcium, manganese, strontium, iron, and uranium, SIs for the above minerals vary by a factor of five. Calculations suggest that well R-7 (screen \#3) is continuously re-equilibrating with groundwater. Fewer variations in Sls and partial pressure of carbon dioxide gas are expected when equilibrium conditions are established and residual drilling fluid is removed from the well. 


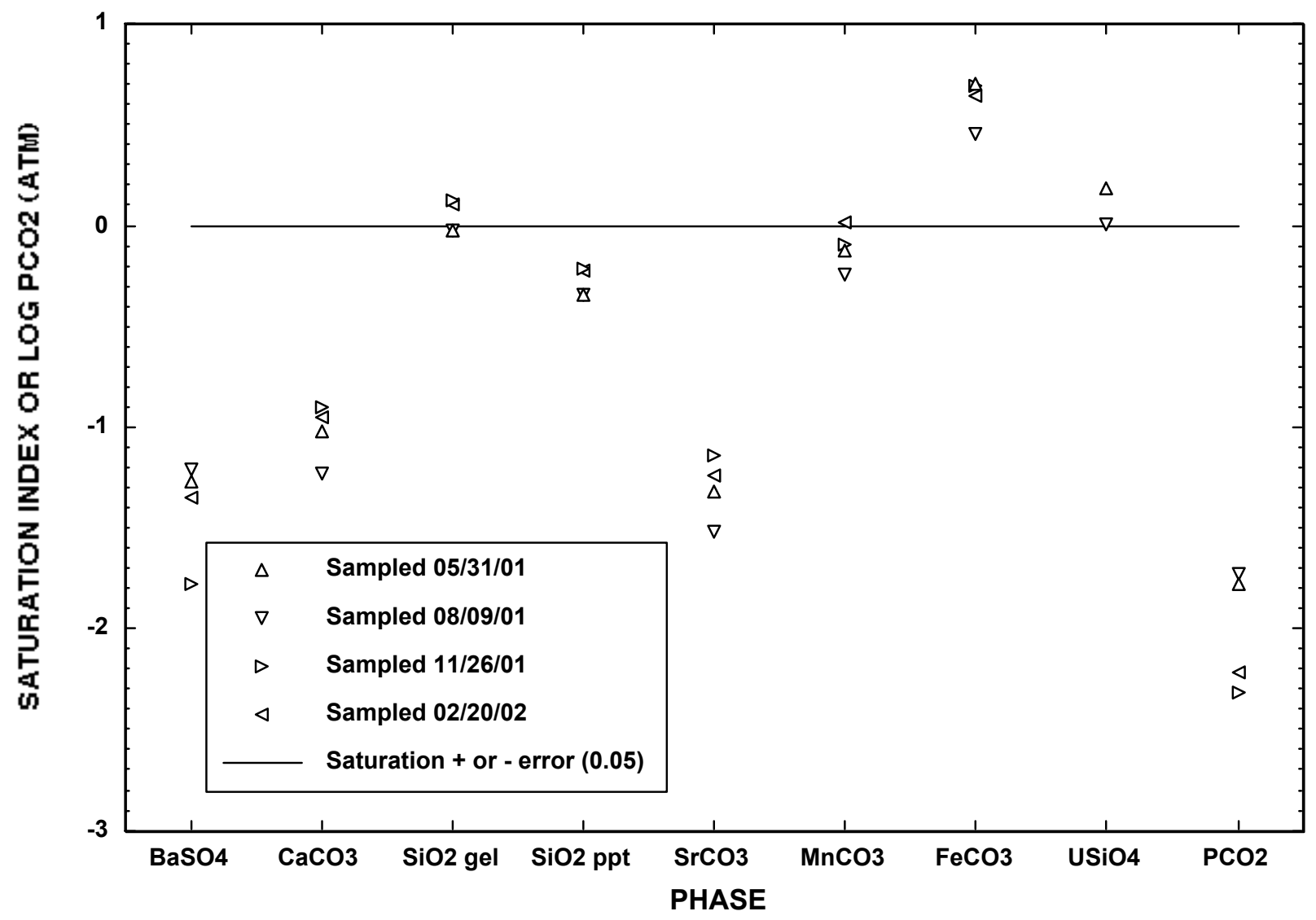

Figure 6.3-2. Results of saturation index calculations using MINTEQA2 for well R-7 (regional aquifer, $915.0 \mathrm{ft}$ )

\subsection{Adsorption/Desorption Calculations}

Adsorption/desorption calculations using the computer program MINTEQA2 (Allison et al. 1991, 49930) were performed to evaluate the release of nickel to the regional aquifer in well R-7. These calculations are based on the hypothesis that hydrous ferric oxide (HFO) is a natural adsorbent present in the altered (glass rich) Puye Formation that has undergone reductive dissolution. Adsorption/desorption calculation results are provided in Table 6.4-1. The diffuse double layer adsorption model was used in the calculations. The calculation includes the mass and specific surface area of adsorbent (HFO), high (strong) and low (weak) energy binding sites, aqueous speciation, ionic strength, and $\mathrm{pH}$ (Allison et al. 1991, 49930). Surface complexation (intrinsic) constants for adsorption of nickel by HFO at $25^{\circ} \mathrm{C}$ are provided below (Allison et al. 1991, 49930):

$$
\begin{aligned}
& \text { strong binding site: } \mathrm{Fe}_{-}{ }^{\mathrm{s}} \mathrm{OH}+\mathrm{Ni}^{2+}=\mathrm{Fe}_{-}{ }^{\mathrm{s}} \mathrm{OHNi}{ }^{2+}\left(\log \mathrm{K}_{1}{ }^{\text {int }}=0.15\right) \text { and } \\
& \text { weak binding site: } \mathrm{Fe}{ }_{-}{ }^{\mathrm{w}} \mathrm{OH}+\mathrm{Ni}^{2+}-\mathrm{H}^{+}=\mathrm{Fe}_{-}{ }^{\mathrm{w}} \mathrm{ONi}^{+}\left(\log _{2}{ }^{\text {int }}=-2.5\right) \text {. }
\end{aligned}
$$


Table 6.4-1

Results of Adsorption Calculations Using MINTEQA2 for Well R-7 Sampled on May 31, 2001 (Screen \#3, Regional Aquifer), Upper Los Alamos Canyon

\begin{tabular}{|c|c|c|}
\hline Parameter & Value & Surface Complex \\
\hline Concentration of HFO $(\mathrm{g} / \mathrm{L})$ & 0.018 & Not applicable \\
\hline Specific surface area $\left(\mathrm{m}^{2} / \mathrm{g}\right)$ & 600 & Not applicable \\
\hline Ionic strength & 0.004 molal & Not applicable \\
\hline $\mathrm{pH}$ & 6.91 & Not applicable \\
\hline Concentration of total Ni molal (mg/L) & 3.749E-06 (0.220) & Not applicable \\
\hline Percentage Ni dissolved & 93.6 & Not applicable \\
\hline Molality (mg/L) & 3.508E-06 (0.206) & Not applicable \\
\hline Percentage $\mathrm{Ni}$ adsorbed & 6.4 & Not applicable \\
\hline Molality (mg/L) & 2.399E-07 (0.014) & Not applicable \\
\hline Percentage $\mathrm{Ni}$ adsorbed to strong binding site & 5.7 & $\equiv \mathrm{Fe}_{-}^{\mathrm{s}} \mathrm{OHNi}{ }^{2+}$ \\
\hline Molality of adsorbed complex (mg/L) & $2.118 \mathrm{E}-07(0.012)$ & $\equiv \mathrm{Fe}_{-}^{\mathrm{s}} \mathrm{OHNi}{ }^{2+}$ \\
\hline Percentage $\mathrm{Ni}$ adsorbed to weak binding site & 0.7 & $\equiv \mathrm{Fe}_{-}{ }^{\mathrm{w}} \mathrm{ONi}^{+}$ \\
\hline Molality of adsorbed complex (mg/L) & $2.812 \mathrm{E}-08(0.002)$ & $\equiv \mathrm{Fe}{ }^{\mathrm{w}} \mathrm{ONi}^{+}$ \\
\hline Speciation of dissolved and adsorbed $\mathrm{Ni}(\%)$ & $\begin{array}{l}\mathrm{Ni}^{2+}(17.3), \mathrm{NiCO}_{3}{ }^{0}(72.3), \mathrm{NiHCO}_{3}^{+}(3.8), \\
\equiv \mathrm{Fe}_{-}^{\mathrm{s}} \mathrm{OHNi}{ }^{2+}(5.65), \equiv \mathrm{Fe}{ }^{\mathrm{w}} \mathrm{ONi}^{+}(0.75)\end{array}$ & Not applicable \\
\hline
\end{tabular}

For the adsorption/desorption calculations, it is assumed that all of the dissolved iron is from the dissolution of HFO, and total nickel concentrations were used to account for the concentration of this trace element in the aquifer system. Results of the calculations show that 0.206 and $0.014 \mathrm{mg} / \mathrm{L} \mathrm{nickel} \mathrm{is}$ dissolved and adsorbed, respectively. These values compare very well with the measured 0.210 and $0.220 \mathrm{mg} / \mathrm{L}$ of dissolved and total nickel, respectively, at well R-7. The calculations suggest that the dominant aqueous species of nickel is $\mathrm{NiCO}_{3}{ }^{0}$ and that $\mathrm{Ni}^{2+}$ and $\mathrm{NiHCO}_{3}{ }^{+}$are present in small concentrations. Results of the MINTEQA2 calculations support the hypothesis that elevated natural iron and nickel at well R-7 result from the reductive dissolution of HFO followed by desorption of nickel.

\subsection{CONCLUSIONS}

Four rounds of groundwater characterization samples collected at well R-7 were analyzed for radionuclides, metals and trace elements, major ions, HE compounds, DOC, TOC, organic compounds, and stable isotopes. The results showed that the groundwater has not been impacted by Laboratory discharges from TA-2 and TA-21. Activities of tritium at well R-7 ranged between 1.34 and $3.38 \mathrm{pCi} / \mathrm{L}$, suggesting that a major component of the groundwater is greater than 35 years old and predates the beginning of atmospheric nuclear testing (based on the cosmogenic baseline of tritium of $19 \mathrm{pCi} / \mathrm{L}$ prior to testing). The majority of natural tritium has decayed to helium. Well R-7 groundwater contains a minor component of pre-nuclear testing tritium that has mixed with native groundwater.

Americium-241, cesium-137, plutonium-238, plutonium-239,240, strontium-90, technetium-99, and uranium-235 were not detected in the groundwater samples collected from well R-7. Activities of uranium234 and uranium-238 were generally detected only at concentrations less than $0.05 \mathrm{pCi} / \mathrm{L}$, which are similar to activities of isotopic uranium measured in supply wells Otowi (O)-1, O-4, Pajarito Mesa (PM)-1 through PM-5, and the Guaje well field (ESP 2001, 71301). Gross alpha and gross beta activities were 
less than $5 \mathrm{pCi} / \mathrm{L}$ in well R-7. Activities of gross gamma activity ranging between 122 and $181 \mathrm{pCi} / \mathrm{L}$ were attributed to isotopes within the natural uranium-238, uranium-235, and thorium-232 decay chains.

Analytical results for well R-7 show that solute concentrations within the regional aquifer, excluding manganese (EPA secondary standard for drinking water of $0.05 \mathrm{mg} / \mathrm{L}$ ), nickel (EPA primary standard for drinking water of $0.1 \mathrm{mg} / \mathrm{L}$ ), and iron (EPA secondary standard for drinking water of $0.3 \mathrm{mg} / \mathrm{L}$ ), were below standards established by the EPA and NMWQCC. Maximum concentrations of dissolved iron, nickel, and manganese detected in screen \#3 (first and second sampling rounds) were 17.0, 0.210, and $3.40 \mathrm{mg} / \mathrm{L}$, respectively. Elevated concentrations of natural iron and manganese were the result of reductive dissolution of ferric (oxy)hydroxide and manganese dioxide in the presence of residual drilling fluid at well R-7. It is hypothesized that elevated concentrations of nickel resulted from the reductive dissolution of ferric (oxy)hydroxide. Concentrations of natural iron, nickel, and manganese decreased during characterization sampling, suggesting that residual drilling fluids are breaking down or dissociating and that the well is re-equilibrating with groundwater in the regional aquifer.

Groundwater within the perched zone and regional aquifer consisted of a calcium-sodium-bicarbonate ionic composition. Calculated TDS in the upper Puye Formation (screen \#1, perched zone) ranged from 121 to $163 \mathrm{mg} / \mathrm{L}$ and from 215 to $234 \mathrm{mg} / \mathrm{L}$ in the lower Puye Formation (screen \#3, regional aquifer). The low TDS suggests that residence time in both the perched zone and upper portion of the regional aquifer are short as compared to other wells (O-4, PM-1, PM-3) that are characterized by higher concentrations of major ions.

Average detectable concentrations of dissolved chloride, fluoride, nitrate plus nitrite (as $\mathrm{N}$ ), and sulfate were $1.54,0.15,0.19$, and $2.37 \mathrm{mg} / \mathrm{L}$, respectively, within the perched zone (378.0 ft) at well R-7. Average detectable concentrations of dissolved chloride, fluoride, nitrate plus nitrite (as $\mathrm{N}$ ), and sulfate were 2.06, 0.36, 0.05 (single detection), and 0.41 (single detection) $\mathrm{mg} / \mathrm{L}$, respectively, within the regional aquifer at a depth of $915.0 \mathrm{ft}$.

Stable isotope ratios of $\delta \mathrm{D}$ and $\delta^{18} \mathrm{O}$ imply that the sampled groundwater at well R-7 was derived from a local meteoric source (Sierra de los Valles) that consists of precipitation and surface water. Results of $\delta^{15} \mathrm{~N}_{\text {AIR }}-\mathrm{NO}_{3}$ analyses suggest that some fractionation of natural nitrate plus nitrite (as $\mathrm{N}$ ) has occurred $(+0.9$ to $+3.3 \%$ ) , implying that biochemical reactions control the distribution of nitrogen at the well.

Geochemical calculations using the computer program MINTEQA2 were performed to evaluate solute speciation, adsorption, and mineral equilibrium in assessing groundwater chemistry and refining the geochemical conceptual model for well R-7. Geochemical calculations show that well R-7 is reequilibrating with groundwater entering the well screen \#3 because of the presence of residual drilling fluid. Dissolved nickel is calculated to be stable as $\mathrm{NiCO}_{3}{ }^{0}$ that poorly adsorbs onto hydrous ferric oxide. Uranium(IV) is calculated to be stable as $\mathrm{U}(\mathrm{OH})_{4}{ }^{0}$ under induced reducing conditions characterized by elevated TOC and DOC and the absence of sulfate in the regional aquifer at well R-7. As oxidizing conditions become re-established during breakdown of drilling fluids, uranyl hydroxo and uranyl carbonato complexes are calculated to be stable in the regional aquifer at well R-7.

Groundwater samples collected from the perched zone (screen \#1) were calculated to be undersaturated with respect to $\mathrm{BaSO}_{4}, \mathrm{CaCO}_{3}$ (calcite), $\mathrm{MnCO}_{3}, \mathrm{SrCO}_{3}$, and amorphous silica precipitate. This groundwater was calculated to be in equilibrium or slightly oversaturated with respect to silica gel. The regional aquifer at well R-7 (screen \#3) was calculated to be undersaturated with respect to $\mathrm{BaSO}_{4}$, $\mathrm{NiCO}_{3}, \mathrm{Ni}(\mathrm{OH})_{2}, \mathrm{CaCO}_{3}$, silica precipitate, and $\mathrm{SrCO}_{3}$ and was oversaturated with respect to silica gel, $\mathrm{FeCO}_{3}$, and $\mathrm{USiO}_{4}$. Regional aquifer groundwater showed variable saturation with respect to $\mathrm{MnCO}_{3}$. 
These results are generally consistent with observed mineralogy (i.e., the absence of strontium carbonate and the presence of silica glass) in the upper Puye Formation at well R-7. Variation in the SI values for $\mathrm{CaCO}_{3}, \mathrm{FeCO}_{3}, \mathrm{MnCO}_{3}, \mathrm{SrCO}_{3}$, and $\mathrm{PCO}_{2}$ gas results from differing temperatures, carbonate alkalinity, $\mathrm{pH}$, and activities of calcium, iron, manganese, and strontium in the groundwater.

\subsection{ACKNOWLEDGEMENTS}

The following individuals contributed to the geochemical investigation conducted during characterization sampling at well R-7 and the review and production of this report.

A. Groffman provided data management.

A. Banar, J. Kofoed, S. Perdue, and D. Steven collected groundwater samples and recorded field parameters at well R-7.

The Groundwater Integration Team, led by C. Nylander, participated in the planning of data collection during the investigation.

D. Broxton and J. McCann supported this investigation as leaders of the Groundwater Protection Program.

R. Enz provided DOE oversight during the investigation.

R. Bohn, D. Broxton, J. English, R. Enz, A. Groffman, E. Louderbough, and J. McCann were reviewers for the document.

M. Sachdeva was editor for this document. P. Maestas was the compositor.

P.T. Herrera provided administrative support in preparing this report.

\subsection{REFERENCES}

Adams, A.I., F. Goff, and D. Counce, February 1995. "Chemical and Isotopic Variations of Precipitation in the Los Alamos Region, New Mexico," Los Alamos National Laboratory report LA-12895-MS, Los Alamos, New Mexico. (Adams et al. 1995, 47192)

Allison, J.D., D.S. Brown, and K.J. Novo-Gradac, March 1991. "MINTEQA2/PRODEFA2, A Geochemical Assessment Model for Environmental Systems: Version 3.0 User's Manual," EPA/600/3- 91/021, Office of Research and Development, Athens, Georgia. (Allison et al. 1991, 49930)

Blake, W.D., F. Goff, A.I. Adams, and D. Counce, May 1995. "Environmental Geochemistry for Surface and Subsurface Waters in the Pajarito Plateau and Outlying Areas, New Mexico," Los Alamos National Laboratory report LA-12912-MS, Los Alamos, New Mexico. (Blake et al. 1995, 49931)

Broxton, D., R. Warren, P. Longmire, R. Gilkeson, S. Johnson, D. Rogers, W. Stone, B. Newman, M. Everett, D. Vaniman, S. McLin, J. Skalski, and D. Larssen, March 2002. "Characterization Well R-25 Completion Report," Los Alamos National Laboratory report LA-13909-MS, Los Alamos, New Mexico. (Broxton et al. 2002, 72717)

Clark, I. D., and P. Fritz, 1997. Environmental Isotopes in Hydrogeology, Lewis Publishers, New York, New York. (Clark and Fritz 1997, 59168) 
Craig, H., and D. Lal, 1961. "The Production Rate of Natural Tritium," Tellus, 8, 85-105. (Craig and Lal 1961, 73696)

ESP (Environmental Surveillance Program), December 2000. "Environmental Surveillance at Los Alamos during 1999," Los Alamos National Laboratory report LA-13775-ENV, Los Alamos, New Mexico. (ESP 2000, 68661)

ESP (Environmental Surveillance Program), October 2001. "Environmental Surveillance at Los Alamos during 2000," Los Alamos National Laboratory report LA-13861-ENV, Los Alamos, New Mexico. (ESP 2001, 71301)

Goff, F., and S. Sayer, 1980. "A Geothermal Investigation of Spring and Well Waters of the Los Alamos Region, New Mexico," Los Alamos National Laboratory report LA-8326-MS, Los Alamos, New Mexico. (Goff and Sayer, 73686)

Grenthe, I. et al., eds., 1992. Chemical Thermodynamics of Uranium, Chemical Thermodynamics Ser., Amsterdam: Elsevier Science Publ., New York, New York, 1-715. (Grenthe et al. 1992, 71511)

Hoefs, J., 1973. Stable Isotope Geochemistry. Springer-Verlag, New York, New York. (Hoefs 1973, 73685)

Kaufman, S., and W.F. Libby, 1954. "The Natural Distribution of Tritium," Phys. Rev., 93, 1337-1344. (Kaufman and Libby 1954, 73685)

Langmuir, D., 1997. Aqueous Environmental Geochemistry, Prentice-Hall, Inc., Upper Saddle River, New Jersey. (Langmuir 1997, 56037)

LANL (Los Alamos National Laboratory), January 31, 1996. "Groundwater Protection Management Program Plan,” Rev. 2.0, Los Alamos, New Mexico. (LANL 1996, 70215)

LANL (Los Alamos National Laboratory), May 22, 1998. "Hydrogeologic Workplan," Los Alamos, New Mexico. (LANL 1998, 59599)

Longmire, P., March 2002. "Characterization Well R-15 Geochemistry Report," Los Alamos National Laboratory report LA-13896-MS, Los Alamos, New Mexico. (Longmire 2002, 72614)

Longmire, P., April 2002. "Characterization Wells R-9 and R-9i Geochemistry Report," Los Alamos National Laboratory report LA-13927-MS, Los Alamos, New Mexico. (Longmire 2002, 72713)

Longmire, P., June 2002. "Characterization Well R-12 Geochemistry Report," Los Alamos National Laboratory report LA-13952-MS, Los Alamos, New Mexico. (Longmire 2002, 72800)

Longmire, P., June 2002. "Characterization Well R-19 Geochemistry Report," Los Alamos National Laboratory report LA-13964-MS, Los Alamos, New Mexico. (Longmire 2002, 73282)

Longmire, P., September 2002. "Characterization Well R-22 Geochemistry Report," Los Alamos National Laboratory report LA-13986-MS, Los Alamos, New Mexico. (Longmire 2002, 73676)

Purtymun, W.D., and S. Johansen, 1974. "General Geohydrology of the Pajarito Plateau," in New Mexico Geological Society Guidebook, $25^{\text {th }}$ Field Conference, Ghost Ranch, New Mexico, 347-349. (Purtymun and Johansen 1974, 11835) 
Shevenell, L., and F. Goff, 1995. "The Use of Tritium in Groundwater to Determine Fluid Mean Residence Times of Valles Caldera Hydrothermal Fluids, New Mexico, USA," J. Volcan. Geotherm. Res., 67, 187-205. (Shevenall and Goff 1995, 73686)

Stone, W., D. Vaniman, P. Longmire, D. Broxton, M. Everett, R. Lawrence, and D. Larssen, April 2002. "Characterization Well R-7 Completion Report," Los Alamos National Laboratory report LA-13932-MS, Los Alamos, New Mexico. (Stone et al 2002, 72717)

Thurman, E.M., 1985. Organic Geochemistry of Natural Waters, Martinus Nijhoff/Dr. W. Junk Publishers, Boston, Massachusetts, p. 14. (Thurman 1985, 71514)

Vilks, P., and D.B. Bachinski, 1996. "Characterization of Organics in Whiteshell Research Area Groundwater and the Implications for Radionuclide Transport," Appl. Geochem., 11, 387-402. (Vilks and Bachinski 1996, 71515)

Vuataz, F.-D., and F. Goff, 1986. "Isotope Geochemistry of Thermal and Nonthermal Waters in the Valles Caldera, Jemez Mountains, Northern New Mexico," J. Geophys. Res., 91, 1835-1853. (Vuataz and Goff 1986, 73687) 



\section{Appendix A}

Groundwater Analytical Results 

Table A-1

Regional Well R-7 Screen 1 First Round Sample Results: Data Summary for Inorganic Chemicals

\begin{tabular}{|c|c|c|c|c|c|c|c|c|c|c|c|c|}
\hline $\begin{array}{l}\text { Parameter } \\
\text { and } \\
\text { Analyte }\end{array}$ & Screen & $\begin{array}{c}\text { Depth } \\
\text { (ft) }\end{array}$ & $\begin{array}{l}\text { Collection } \\
\text { Date }\end{array}$ & $\begin{array}{c}\text { Field } \\
\text { Preparation }\end{array}$ & $\begin{array}{l}\text { Number } \\
\text { of } \\
\text { Analyses }\end{array}$ & $\begin{array}{c}\text { Number } \\
\text { of } \\
\text { Detects }\end{array}$ & $\begin{array}{c}\text { Detected } \\
\text { Value } \\
\text { ( } \mu \mathrm{g} / \mathrm{L})\end{array}$ & $\begin{array}{l}\text { Non- } \\
\text { detected } \\
\text { Value } \\
(\mu \mathrm{g} / \mathrm{L})\end{array}$ & $\begin{array}{l}\text { Drinking } \\
\text { Water } \\
\text { MCL }^{\mathrm{b}} \\
(\mu \mathrm{g} / \mathrm{L})\end{array}$ & $\begin{array}{l}\text { Frequency } \\
\text { of Detects } \\
>\text { Drinking } \\
\text { Water MCL }\end{array}$ & $\begin{array}{c}\text { NMED }^{c} \\
\text { Groundwater } \\
\text { Standard }^{\mathrm{d}} \\
(\mu \mathrm{g} / \mathrm{L})\end{array}$ & $\begin{array}{l}\text { Frequency of } \\
\text { Detects }>\text { NMED } \\
\text { Groundwater } \\
\text { Standard }\end{array}$ \\
\hline \multicolumn{13}{|l|}{ Field Parameter } \\
\hline $\begin{array}{l}\text { Field Alkalinity } \\
\text { (total as } \mathrm{CaCO}_{3} \text { ) }\end{array}$ & 1 & 378 & 05/30/01 & $\mathrm{NF}^{\mathrm{e}}$ & 1 & 1 & 41000 & $-^{f}$ & - & - & - & - \\
\hline Dissolved Oxygen & 1 & 378 & 05/30/01 & NF & 0 & 0 & - & - & - & - & - & - \\
\hline $\mathrm{pH}$ & 1 & 378 & 05/30/01 & NF & 1 & 1 & 6.68 & - & $>6 \&<9$ & $0 / 1$ & $>6 \&<9$ & $0 / 1$ \\
\hline $\begin{array}{l}\text { Specific Conductance } \\
(\mu \mathrm{S} / \mathrm{cm})\end{array}$ & 1 & 378 & 05/30/01 & NF & 1 & 1 & 131 & - & - & $0 / 1$ & - & $0 / 1$ \\
\hline Temperature $\left({ }^{\circ} \mathrm{C}\right)$ & 1 & 378 & 05/30/01 & NF & 1 & 1 & 14.3 & - & - & $0 / 1$ & - & $0 / 1$ \\
\hline Turbidity (NTU9) & 1 & 378 & 05/30/01 & NF & 1 & 1 & 2.0 & - & - & $0 / 1$ & - & $0 / 1$ \\
\hline \multicolumn{13}{|l|}{ Analyte } \\
\hline $\begin{array}{l}\text { Lab Alkalinity } \\
\text { (total as } \mathrm{CaCO}_{3} \text { ) }\end{array}$ & 1 & 378 & 05/30/01 & $\mathrm{F}^{\mathrm{h}}$ & 1 & 1 & 67000 & - & - & - & - & - \\
\hline Aluminum & 1 & 378 & 05/30/01 & $\mathrm{F}$ & 1 & 0 & - & [7.6] & 50 & $0 / 1$ & 5000 & $0 / 1$ \\
\hline Aluminum & 1 & 378 & 05/30/01 & NF & 1 & 0 & - & [7.6] & - & - & - & - \\
\hline Ammonia (as N) & 1 & 378 & 05/30/01 & $\mathrm{F}$ & 1 & 0 & - & [100] & - & - & - & - \\
\hline Antimony & 1 & 378 & 05/30/01 & $\mathrm{F}$ & 1 & 1 & 0.282 & - & 6 & $0 / 1$ & - & - \\
\hline Antimony & 1 & 378 & 05/30/01 & $\mathrm{NF}$ & 1 & 1 & 1.07 & - & - & - & - & - \\
\hline Arsenic & 1 & 378 & 05/30/01 & $\mathrm{F}$ & 1 & 0 & - & {$[1.5]$} & 50 & $0 / 1$ & 100 & $0 / 1$ \\
\hline Arsenic & 1 & 378 & 05/30/01 & NF & 1 & 0 & - & [1.5] & - & - & - & - \\
\hline Barium & 1 & 378 & 05/30/01 & $\mathrm{F}$ & 1 & 1 & 74 & - & 2000 & $0 / 1$ & 1000 & $0 / 1$ \\
\hline Barium & 1 & 378 & 05/30/01 & NF & 1 & 1 & 81 & - & - & - & - & - \\
\hline Beryllium & 1 & 378 & 05/30/01 & $\mathrm{F}$ & 1 & 0 & - & {$[0.012]$} & 4 & $0 / 1$ & - & - \\
\hline Beryllium & 1 & 378 & 05/30/01 & NF & 1 & 1 & 0.503 & - & - & - & - & - \\
\hline Boron & 1 & 378 & 05/30/01 & $\mathrm{F}$ & 1 & 1 & 12 & - & - & - & 750 & $0 / 1$ \\
\hline Boron & 1 & 378 & 05/30/01 & NF & 1 & 1 & 13 & - & - & - & - & - \\
\hline Bromide & 1 & 378 & 05/30/01 & $\mathrm{F}$ & 1 & 0 & - & [200] & - & - & - & - \\
\hline
\end{tabular}


Table A-1 (continued)

\begin{tabular}{|c|c|c|c|c|c|c|c|c|c|c|c|c|}
\hline $\begin{array}{l}\text { Parameter } \\
\text { and } \\
\text { Analyte }\end{array}$ & Screen & $\begin{array}{l}\text { Depth } \\
(\mathrm{ft})^{a}\end{array}$ & $\begin{array}{l}\text { Collection } \\
\text { Date }\end{array}$ & $\begin{array}{c}\text { Field } \\
\text { Preparation }\end{array}$ & $\begin{array}{l}\text { Number } \\
\text { of } \\
\text { Analyses }\end{array}$ & $\begin{array}{c}\text { Number } \\
\text { of } \\
\text { Detects }\end{array}$ & $\begin{array}{c}\text { Detected } \\
\text { Value } \\
\text { ( } \mu \mathrm{g} / \mathrm{L})\end{array}$ & $\begin{array}{c}\text { Non- } \\
\text { detected } \\
\text { Value } \\
(\mu \mathrm{g} / \mathrm{L})\end{array}$ & $\begin{array}{l}\text { Drinking } \\
\text { Water } \\
M^{\prime} L^{b} \\
(\mu \mathrm{g} / \mathrm{L})\end{array}$ & $\begin{array}{l}\text { Frequency } \\
\text { of Detects } \\
>\text { Drinking } \\
\text { Water MCL }\end{array}$ & $\begin{array}{c}\text { NMED }^{c} \\
\text { Groundwater } \\
\text { Standard }^{\mathrm{d}} \\
(\mu \mathrm{g} / \mathrm{L})\end{array}$ & $\begin{array}{l}\text { Frequency of } \\
\text { Detects }>\text { NMED } \\
\text { Groundwater } \\
\text { Standard }\end{array}$ \\
\hline Cadmium & 1 & 378 & 05/30/01 & $\mathrm{F}$ & 1 & 0 & - & {$[0.066]$} & 5 & $0 / 1$ & 10 & $0 / 1$ \\
\hline Cadmium & 1 & 378 & 05/30/01 & NF & 1 & 1 & 0.23 & - & - & - & - & - \\
\hline Calcium & 1 & 378 & 05/30/01 & $\mathrm{F}$ & 1 & 1 & 16000 & - & - & - & - & - \\
\hline Calcium & 1 & 378 & 05/30/01 & NF & 1 & 1 & 18000 & - & - & - & - & - \\
\hline Chloride & 1 & 378 & 05/30/01 & $\mathrm{F}$ & 1 & 1 & 1600 & - & 250000 & $0 / 1$ & 250000 & $0 / 1$ \\
\hline Chromium (total) & 1 & 378 & 05/30/01 & $\mathrm{F}$ & 1 & 1 & 1 & - & 100 & $0 / 1$ & 50 & $0 / 1$ \\
\hline Chromium (total) & 1 & 378 & 05/30/01 & NF & 1 & 1 & 12 & - & - & - & - & - \\
\hline Cobalt & 1 & 378 & 05/30/01 & $\mathrm{F}$ & 1 & 0 & - & {$[0.37]$} & - & - & 50 & $0 / 1$ \\
\hline Cobalt & 1 & 378 & 05/30/01 & NF & 1 & 0 & - & {$[0.37]$} & - & - & - & - \\
\hline Copper & 1 & 378 & 05/30/01 & $\mathrm{F}$ & 1 & 0 & - & {$[0.27]$} & 1300 & $0 / 1$ & 1000 & $0 / 1$ \\
\hline Copper & 1 & 378 & 05/30/01 & NF & 1 & 0 & - & {$[0.27]$} & - & - & - & - \\
\hline Cyanide (total) & 1 & 378 & 05/30/01 & NF & 1 & 0 & - & [100] & - & - & - & - \\
\hline Fluoride & 1 & 378 & 05/30/01 & $\mathrm{F}$ & 1 & 1 & 220 & - & 4000 & $0 / 1$ & 1600 & $0 / 1$ \\
\hline Iron & 1 & 378 & 05/30/01 & $\mathrm{F}$ & 1 & 0 & - & [69] & 300 & $0 / 1$ & 1000 & $0 / 1$ \\
\hline Iron & 1 & 378 & 05/30/01 & NF & 1 & 0 & - & [130] & - & - & - & - \\
\hline Lead & 1 & 378 & 05/30/01 & $\mathrm{F}$ & 1 & 0 & - & {$[0.037]$} & 15 & $0 / 1$ & 50 & $0 / 1$ \\
\hline Lead & 1 & 378 & 05/30/01 & NF & 1 & 1 & 0.59 & - & - & - & - & - \\
\hline Magnesium & 1 & 378 & 05/30/01 & $\mathrm{F}$ & 1 & 1 & 2000 & - & - & - & - & - \\
\hline Magnesium & 1 & 378 & 05/30/01 & NF & 1 & 1 & 2200 & - & - & - & - & - \\
\hline Manganese & 1 & 378 & 05/30/01 & $\mathrm{F}$ & 1 & 1 & 80 & - & 50 & $1 / 1$ & 200 & $0 / 1$ \\
\hline Manganese & 1 & 378 & 05/30/01 & NF & 1 & 1 & 83 & - & - & - & - & - \\
\hline Mercury & 1 & 378 & 05/30/01 & $\mathrm{F}$ & 1 & 0 & - & {$[0.033]$} & 2 & $0 / 1$ & - & - \\
\hline Mercury & 1 & 378 & 05/30/01 & NF & 1 & 0 & - & [0.033] & - & - & 2 & $0 / 1$ \\
\hline Molybdenum & 1 & 378 & 05/30/01 & $\mathrm{F}$ & 1 & 1 & 3.8 & - & - & - & - & - \\
\hline Molybdenum & 1 & 378 & 05/30/01 & NF & 1 & 1 & 6.5 & - & - & - & - & - \\
\hline Nickel & 1 & 378 & 05/30/01 & $\mathrm{F}$ & 1 & 1 & 1.7 & - & 100 & $0 / 1$ & 200 & $0 / 1$ \\
\hline Nickel & 1 & 378 & 05/30/01 & NF & 1 & 1 & 9.4 & - & - & - & - & - \\
\hline
\end{tabular}


Table A-1 (continued)

\begin{tabular}{|c|c|c|c|c|c|c|c|c|c|c|c|c|}
\hline $\begin{array}{l}\text { Parameter } \\
\text { and } \\
\text { Analyte }\end{array}$ & Screen & $\begin{array}{l}\text { Depth } \\
(\mathrm{ft})^{a}\end{array}$ & $\begin{array}{c}\text { Collection } \\
\text { Date }\end{array}$ & $\begin{array}{c}\text { Field } \\
\text { Preparation }\end{array}$ & $\begin{array}{l}\text { Number } \\
\text { of } \\
\text { Analyses }\end{array}$ & $\begin{array}{c}\text { Number } \\
\text { of } \\
\text { Detects }\end{array}$ & $\begin{array}{c}\text { Detected } \\
\text { Value } \\
(\mu \mathrm{g} / \mathrm{L})\end{array}$ & $\begin{array}{l}\text { Non- } \\
\text { detected } \\
\text { Value } \\
(\mu \mathrm{g} / \mathrm{L})\end{array}$ & $\begin{array}{l}\text { Drinking } \\
\text { Water } \\
\text { MCL }^{\mathrm{b}} \\
(\mu \mathrm{g} / \mathrm{L})\end{array}$ & $\begin{array}{l}\text { Frequency } \\
\text { of Detects } \\
>\text { Drinking } \\
\text { Water MCL }\end{array}$ & $\begin{array}{c}\text { NMED }^{c} \\
\text { Groundwater } \\
\text { Standard }^{\mathrm{d}} \\
(\mu \mathrm{g} / \mathrm{L})\end{array}$ & $\begin{array}{l}\text { Frequency of } \\
\text { Detects }>\text { NMED } \\
\text { Groundwater } \\
\text { Standard }\end{array}$ \\
\hline Nitrate + Nitrite (as N) & 1 & 378 & 05/30/01 & $\mathrm{F}$ & 1 & 1 & 100 & - & 10000 & $0 / 1$ & - & - \\
\hline Perchlorate & 1 & 378 & 05/30/01 & $\mathrm{F}$ & 1 & 0 & - & [4] & - & - & - & - \\
\hline Phosphorus (as P) & 1 & 378 & 05/30/01 & $\mathrm{F}$ & 1 & 0 & - & [50] & - & - & - & - \\
\hline Potassium & 1 & 378 & $05 / 30 / 01$ & $\mathrm{~F}$ & 1 & 1 & 3300 & - & - & - & - & - \\
\hline Potassium & 1 & 378 & 05/30/01 & NF & 1 & 1 & 3300 & - & - & - & - & - \\
\hline Selenium & 1 & 378 & 05/30/01 & $\mathrm{F}$ & 1 & 0 & - & [1.9] & 50 & $0 / 1$ & 50 & $0 / 1$ \\
\hline Selenium & 1 & 378 & $05 / 30 / 01$ & NF & 1 & 0 & - & [1.9] & - & - & - & - \\
\hline Silver & 1 & 378 & 05/30/01 & $\mathrm{F}$ & 1 & 0 & - & {$[0.57]$} & 100 & $0 / 1$ & 50 & $0 / 1$ \\
\hline Silver & 1 & 378 & 05/30/01 & $\mathrm{NF}$ & 1 & 0 & - & {$[0.57]$} & - & - & - & - \\
\hline Silica & 1 & 378 & 05/30/01 & $\mathrm{F}$ & 1 & 1 & 64200 & - & - & - & - & - \\
\hline Silica & 1 & 378 & 05/30/01 & NF & 1 & 1 & 66340 & - & - & - & - & - \\
\hline Sodium & 1 & 378 & 05/30/01 & $\mathrm{F}$ & 1 & 1 & 5900 & - & - & - & - & - \\
\hline Sodium & 1 & 378 & 05/30/01 & NF & 1 & 1 & 6000 & - & - & - & - & - \\
\hline Strontium & 1 & 378 & 05/30/01 & $\mathrm{F}$ & 1 & 1 & 73 & - & - & - & - & - \\
\hline Strontium & 1 & 378 & 05/30/01 & NF & 1 & 1 & 81 & - & - & - & - & - \\
\hline Sulfate & 1 & 378 & 05/30/01 & $\mathrm{F}$ & 1 & 1 & 2900 & - & 250000 & $0 / 1$ & 600000 & $0 / 1$ \\
\hline Thallium & 1 & 378 & 05/30/01 & $\mathrm{F}$ & 1 & 1 & 0.273 & - & 2 & $0 / 1$ & - & - \\
\hline Thallium & 1 & 378 & 05/30/01 & NF & 1 & 1 & 0.838 & - & - & - & - & - \\
\hline $\begin{array}{l}\text { Total Kjeldahl } \\
\text { Nitrogen }\end{array}$ & 1 & 378 & 05/30/01 & $\mathrm{F}$ & 1 & 1 & 200 & - & - & - & - & - \\
\hline $\begin{array}{l}\text { Total Kjeldahl } \\
\text { Nitrogen }\end{array}$ & 1 & 378 & 05/30/01 & NF & 1 & 1 & 280 & - & - & - & - & - \\
\hline Uranium & 1 & 378 & 05/30/01 & $\mathrm{F}$ & 1 & 1 & 0.167 & - & - & - & - & - \\
\hline Uranium & 1 & 378 & $05 / 30 / 01$ & NF & 1 & 1 & 0.713 & - & - & - & - & - \\
\hline Vanadium & 1 & 378 & 05/30/01 & $\mathrm{F}$ & 1 & 1 & 0.58 & - & - & - & - & - \\
\hline Vanadium & 1 & 378 & 05/30/01 & NF & 1 & 1 & 0.58 & - & - & - & - & - \\
\hline Zinc & 1 & 378 & 05/30/01 & $\mathrm{F}$ & 1 & 1 & 69 & - & 5000 & $0 / 1$ & 10000 & $0 / 1$ \\
\hline Zinc & 1 & 378 & $05 / 30 / 01$ & NF & 1 & 1 & 73 & - & - & - & - & - \\
\hline
\end{tabular}


Table A-1 (continued)

\begin{tabular}{|c|c|c|c|c|c|c|c|c|c|c|c|c|}
\hline $\begin{array}{l}\text { Parameter } \\
\text { and } \\
\text { Analyte }\end{array}$ & Screen & $\begin{array}{c}\text { Depth } \\
(\mathrm{ft})^{\mathrm{a}}\end{array}$ & $\begin{array}{c}\text { Collection } \\
\text { Date }\end{array}$ & $\begin{array}{c}\text { Field } \\
\text { Preparation }\end{array}$ & $\begin{array}{l}\text { Number } \\
\text { of } \\
\text { Analyses }\end{array}$ & $\begin{array}{c}\text { Number } \\
\text { of } \\
\text { Detects }\end{array}$ & $\begin{array}{l}\text { Detected } \\
\text { Value } \\
\text { ( } \mu \mathrm{g} / \mathrm{L})\end{array}$ & $\begin{array}{c}\text { Non- } \\
\text { detected } \\
\text { Value } \\
(\mu \mathrm{g} / \mathrm{L})\end{array}$ & $\begin{array}{l}\text { Drinking } \\
\text { Water } \\
M L^{b} \\
(\mu g / L)\end{array}$ & $\begin{array}{l}\text { Frequency } \\
\text { of Detects } \\
>\text { Drinking } \\
\text { Water MCL }\end{array}$ & $\begin{array}{c}\text { NMED }^{c} \\
\text { Groundwater } \\
\text { Standard }^{\mathrm{d}} \\
(\mu \mathrm{g} / \mathrm{L})\end{array}$ & $\begin{array}{c}\text { Frequency of } \\
\text { Detects }>\text { NMED } \\
\text { Groundwater } \\
\text { Standard }\end{array}$ \\
\hline \multicolumn{13}{|c|}{ Stable Isotope (\%o) } \\
\hline$\delta D$ & 1 & 378 & $05 / 30 / 01$ & NF & 1 & 1 & -81 & - & - & - & - & - \\
\hline$\delta^{18} \mathrm{O}$ & 1 & 378 & $05 / 30 / 01$ & NF & 1 & 1 & -11.5 & - & - & - & - & - \\
\hline
\end{tabular}

${ }^{\text {a }}$ The static water level for the regional aquifer at R-7 was $902.8 \mathrm{ft}$ when the well was drilled.

${ }^{\mathrm{b}} \mathrm{MCL}=$ Maximum contaminant level. US Environmental Protection Agency (EPA) MCLs are from the National Primary Water Regulations, 40 CFR Part 141. US EPA secondary MCLs are from National Secondary Drinking Water Regulations, 20 NMAC 7.1

${ }^{c}$ NMED $=$ New Mexico Environment Department.

${ }^{d}$ State of New Mexico groundwater standards are from New Mexico Quality Control Commission Regulations, Ground and Surface Water Protection, 20 NMAC 6.2.

${ }^{\mathrm{e}} \mathrm{NF}=$ Nonfiltered

- $=$ Not available or applicable.

${ }^{\mathrm{g}} \mathrm{NTU}=$ Nephelometric turbidity unit

${ }^{h} \mathrm{~F}=$ Filtered. 
Table A-2

Regional Well R-7 Screen 3 First Round Sample Results: Data Summary for Inorganic Chemicals

\begin{tabular}{|c|c|c|c|c|c|c|c|c|c|c|c|c|}
\hline $\begin{array}{l}\text { Parameter } \\
\text { and } \\
\text { Analyte }\end{array}$ & Screen & $\begin{array}{c}\text { Depth } \\
(\mathrm{ft})^{\mathrm{a}}\end{array}$ & $\begin{array}{c}\text { Collection } \\
\text { Date }\end{array}$ & $\begin{array}{c}\text { Field } \\
\text { Preparation }\end{array}$ & $\begin{array}{l}\text { Number } \\
\text { of } \\
\text { Analyses }\end{array}$ & $\begin{array}{c}\text { Number } \\
\text { of } \\
\text { Detects }\end{array}$ & $\begin{array}{c}\text { Detected } \\
\text { Value } \\
\text { ( } \mu \mathrm{g} / \mathrm{L})\end{array}$ & $\begin{array}{c}\text { Non- } \\
\text { detected } \\
\text { Value } \\
(\mu \mathrm{g} / \mathrm{L})\end{array}$ & $\begin{array}{l}\text { Drinking } \\
\text { Water } \\
\text { MCL }^{\mathrm{b}} \\
(\mu \mathrm{g} / \mathrm{L})\end{array}$ & $\begin{array}{l}\text { Frequency } \\
\text { of Detects } \\
>\text { Drinking } \\
\text { Water MCL }\end{array}$ & $\begin{array}{c}\text { NMED }^{c} \\
\text { Groundwater } \\
\text { Standard }^{\mathrm{d}} \\
(\mu \mathrm{g} / \mathrm{L})\end{array}$ & $\begin{array}{c}\text { Frequency of } \\
\text { Detects }>\text { NMED } \\
\text { Groundwater } \\
\text { Standard }\end{array}$ \\
\hline \multicolumn{13}{|l|}{ Field Parameter } \\
\hline $\begin{array}{l}\text { Field Alkalinity } \\
\text { (total as } \mathrm{CaCO}_{3} \text { ) }\end{array}$ & 3 & 915 & 05/31/01 & $\mathrm{NF}^{\mathrm{e}}$ & 1 & 1 & 91000 & $-^{f}$ & - & - & - & - \\
\hline Dissolved Oxygen & 1 & 915 & $05 / 31 / 01$ & NF & 0 & 0 & - & - & - & - & - & - \\
\hline $\mathrm{pH}$ & 3 & 915 & 05/31/01 & $\mathrm{NF}$ & 1 & 1 & 6.91 & - & $>6 \&<9$ & $0 / 1$ & $>6 \&<9$ & $0 / 1$ \\
\hline $\begin{array}{l}\text { Specific Conductance } \\
(\mu \mathrm{S} / \mathrm{cm})\end{array}$ & 3 & 915 & 05/31/01 & NF & 1 & 1 & 266 & - & - & $0 / 1$ & - & $0 / 1$ \\
\hline Temperature $\left({ }^{\circ} \mathrm{C}\right)$ & 3 & 915 & 05/31/01 & NF & 1 & 1 & 19.0 & - & - & $0 / 1$ & - & $0 / 1$ \\
\hline Turbidity (NTUg) & 3 & 915 & $05 / 31 / 01$ & NF & 1 & 1 & 8.7 & - & - & $0 / 1$ & - & $0 / 1$ \\
\hline
\end{tabular}

\section{Analyte}

Lab Alkalinity

(total as $\mathrm{CaCO}_{3}$ )

Aluminum

Aluminum

Ammonia (as N)

Antimony

Antimony

Arsenic

Arsenic

Barium

Barium

Beryllium

\begin{tabular}{|l|l|l}
3 & 915 & $05 /$ \\
3 & 915 & $05 /$
\end{tabular}

\begin{tabular}{|l|l|l}
\hline $05 / 31 / 01$ & $F^{h}$ &
\end{tabular}

\begin{tabular}{|l|l|}
1 & \\
1 &
\end{tabular}

\begin{tabular}{c|c|c}
1 & 120000 \\
\hline 0 & -
\end{tabular}

(2)

\begin{tabular}{c|c|}
\hline \multicolumn{1}{|c|}{} & \\
\hline 5000 & - \\
\hline- & $0 / 1$ \\
\hline- & - \\
\hline- & - \\
\hline- & - \\
\hline 100 & - \\
\hline- & $0 / 1$ \\
\hline 1000 & - \\
\hline- & $0 / 1$ \\
\hline- & - \\
\hline- & - \\
\hline 750 & - \\
\hline- & $0 / 1$ \\
\hline- & - \\
\hline
\end{tabular}


Table A-2 (continued)

\begin{tabular}{|c|c|c|c|c|c|c|c|c|c|c|c|c|}
\hline $\begin{array}{l}\text { Parameter } \\
\text { and } \\
\text { Analyte }\end{array}$ & Screen & $\begin{array}{c}\text { Depth } \\
(\mathrm{ft})^{\mathrm{a}}\end{array}$ & $\begin{array}{l}\text { Collection } \\
\text { Date }\end{array}$ & $\begin{array}{c}\text { Field } \\
\text { Preparation }\end{array}$ & $\begin{array}{l}\text { Number } \\
\text { of } \\
\text { Analyses }\end{array}$ & $\begin{array}{c}\text { Number } \\
\text { of } \\
\text { Detects }\end{array}$ & $\begin{array}{c}\text { Detected } \\
\text { Value } \\
\text { ( } \mu \mathrm{g} / \mathrm{L})\end{array}$ & $\begin{array}{c}\text { Non- } \\
\text { detected } \\
\text { Value } \\
(\mu \mathrm{g} / \mathrm{L})\end{array}$ & $\begin{array}{l}\text { Drinking } \\
\text { Water } \\
M^{\prime} L^{b} \\
(\mu \mathrm{g} / \mathrm{L})\end{array}$ & $\begin{array}{l}\text { Frequency } \\
\text { of Detects } \\
>\text { Drinking } \\
\text { Water MCL }\end{array}$ & $\begin{array}{c}\text { NMED }^{c} \\
\text { Groundwater } \\
\text { Standard }^{\mathrm{d}} \\
(\mu \mathrm{g} / \mathrm{L})\end{array}$ & $\begin{array}{l}\text { Frequency of } \\
\text { Detects }>\text { NMED } \\
\text { Groundwater } \\
\text { Standard }\end{array}$ \\
\hline Cadmium & 3 & 915 & $05 / 31 / 01$ & $\mathrm{~F}$ & 1 & 0 & - & {$[0.196]$} & 5 & $0 / 1$ & 10 & $0 / 1$ \\
\hline Cadmium & 3 & 915 & $05 / 31 / 01$ & NF & 1 & 0 & - & [0.191] & - & - & - & - \\
\hline Calcium & 3 & 915 & $05 / 31 / 01$ & $\mathrm{~F}$ & 1 & 1 & 25000 & - & - & - & - & - \\
\hline Calcium & 3 & 915 & 05/31/01 & NF & 1 & 1 & 26000 & - & - & - & - & - \\
\hline Chloride & 3 & 915 & $05 / 31 / 01$ & $\mathrm{~F}$ & 1 & 1 & 2400 & - & 250000 & $0 / 1$ & 250000 & $0 / 1$ \\
\hline Chromium (total) & 3 & 915 & 05/31/01 & $\mathrm{F}$ & 1 & 1 & 5.8 & - & 100 & $0 / 1$ & 50 & $0 / 1$ \\
\hline Chromium (total) & 3 & 915 & 05/31/01 & NF & 1 & 1 & 8.9 & - & - & - & - & - \\
\hline Cobalt & 3 & 915 & 05/31/01 & $\mathrm{F}$ & 1 & 1 & 14 & - & - & - & 50 & $0 / 1$ \\
\hline Cobalt & 3 & 915 & 05/31/01 & NF & 1 & 1 & 15 & - & - & - & - & - \\
\hline Copper & 3 & 915 & 05/31/01 & $\mathrm{F}$ & 1 & 0 & - & {$[0.27]$} & 1300 & $0 / 1$ & 1000 & $0 / 1$ \\
\hline Copper & 3 & 915 & $05 / 31 / 01$ & NF & 1 & 1 & 1.1 & - & - & - & - & - \\
\hline Cyanide (total) & 3 & 915 & 05/31/01 & NF & 1 & 0 & - & [10] & - & - & - & - \\
\hline Fluoride & 3 & 915 & $05 / 31 / 01$ & $\mathrm{~F}$ & 1 & 1 & 340 & - & 4000 & $0 / 1$ & 1600 & $0 / 1$ \\
\hline Iron & 3 & 915 & 05/31/01 & $\mathrm{F}$ & 1 & 1 & 17000 & - & 300 & $1 / 1$ & 1000 & $1 / 1$ \\
\hline Iron & 3 & 915 & 05/31/01 & NF & 1 & 1 & 18000 & - & - & - & - & - \\
\hline Lead & 3 & 915 & 05/31/01 & $\mathrm{F}$ & 1 & 0 & - & {$[0.037]$} & 15 & $0 / 1$ & 50 & $0 / 1$ \\
\hline Lead & 3 & 915 & 05/31/01 & NF & 1 & 1 & 0.387 & - & - & - & - & - \\
\hline Magnesium & 3 & 915 & $05 / 31 / 01$ & $\mathrm{~F}$ & 1 & 1 & 5400 & - & - & - & - & - \\
\hline Magnesium & 3 & 915 & $05 / 31 / 01$ & NF & 1 & 1 & 5300 & - & - & - & - & - \\
\hline Manganese & 3 & 915 & 05/31/01 & $\mathrm{F}$ & 1 & 1 & 3200 & - & 50 & $1 / 1$ & 200 & $1 / 1$ \\
\hline Manganese & 3 & 915 & $05 / 31 / 01$ & NF & 1 & 1 & 3200 & - & - & - & - & - \\
\hline Mercury & 3 & 915 & 05/31/01 & $\mathrm{F}$ & 1 & 0 & - & {$[0.033]$} & 2 & $0 / 1$ & - & - \\
\hline Mercury & 3 & 915 & 05/31/01 & NF & 1 & 0 & - & [0.033] & - & - & 2 & $0 / 1$ \\
\hline Molybdenum & 3 & 915 & 05/31/01 & $\mathrm{F}$ & 1 & 1 & 31 & - & - & - & - & - \\
\hline Molybdenum & 3 & 915 & 05/31/01 & NF & 1 & 1 & 26 & - & - & - & - & - \\
\hline Nickel & 3 & 915 & 05/31/01 & $\mathrm{F}$ & 1 & 1 & 210 & - & 100 & $1 / 1$ & 200 & $1 / 1$ \\
\hline Nickel & 3 & 915 & $05 / 31 / 01$ & NF & 1 & 1 & 220 & - & - & - & - & - \\
\hline
\end{tabular}


Table A-2 (continued)

\begin{tabular}{|c|c|c|c|c|c|c|c|c|c|c|c|c|}
\hline $\begin{array}{l}\text { Parameter } \\
\text { and } \\
\text { Analyte }\end{array}$ & Screen & $\begin{array}{l}\text { Depth } \\
(\mathrm{ft})^{a}\end{array}$ & $\begin{array}{c}\text { Collection } \\
\text { Date }\end{array}$ & $\begin{array}{c}\text { Field } \\
\text { Preparation }\end{array}$ & $\begin{array}{c}\text { Number } \\
\text { of } \\
\text { Analyses }\end{array}$ & $\begin{array}{c}\text { Number } \\
\text { of } \\
\text { Detects }\end{array}$ & $\begin{array}{c}\text { Detected } \\
\text { Value } \\
\text { ( } \mu \mathrm{g} / \mathrm{L})\end{array}$ & $\begin{array}{l}\text { Non- } \\
\text { detected } \\
\text { Value } \\
(\mu \mathrm{g} / \mathrm{L})\end{array}$ & $\begin{array}{l}\text { Drinking } \\
\text { Water } \\
\text { MCL }^{\mathrm{b}} \\
(\mu \mathrm{g} / \mathrm{L})\end{array}$ & $\begin{array}{l}\text { Frequency } \\
\text { of Detects } \\
>\text { Drinking } \\
\text { Water MCL }\end{array}$ & $\begin{array}{c}\text { NMED }^{c} \\
\text { Groundwater } \\
\text { Standard }^{\mathrm{d}} \\
(\mu \mathrm{g} / \mathrm{L})\end{array}$ & $\begin{array}{c}\text { Frequency of } \\
\text { Detects }>\text { NMED } \\
\text { Groundwater } \\
\text { Standard }\end{array}$ \\
\hline Nitrate + Nitrite (as N) & 3 & 915 & 05/31/01 & $\mathrm{F}$ & 1 & 0 & - & {$[50]$} & 10000 & $0 / 1$ & - & - \\
\hline Oxalate & 3 & 915 & $05 / 31 / 01$ & $\mathrm{~F}$ & 1 & 0 & - & [190] & - & - & - & - \\
\hline Perchlorate & 3 & 915 & 05/31/01 & $\mathrm{F}$ & 1 & 0 & - & [4] & - & - & - & - \\
\hline Phosphorus (as P) & 3 & 915 & 05/31/01 & $\mathrm{F}$ & 1 & 0 & - & [50] & - & - & - & - \\
\hline Potassium & 3 & 915 & 05/31/01 & $\mathrm{F}$ & 1 & 1 & 3400 & - & - & - & - & - \\
\hline Potassium & 3 & 915 & 05/31/01 & $\mathrm{NF}$ & 1 & 1 & 3400 & - & - & - & - & - \\
\hline Selenium & 3 & 915 & 05/31/01 & $\mathrm{F}$ & 1 & 0 & - & [1.9] & 50 & $0 / 1$ & 50 & $0 / 1$ \\
\hline Selenium & 3 & 915 & $05 / 31 / 01$ & NF & 1 & 1 & 2.1 & - & - & - & - & - \\
\hline Silica & 3 & 915 & $05 / 31 / 01$ & $\mathrm{~F}$ & 1 & 1 & 47080 & - & - & - & - & - \\
\hline Silica & 3 & 915 & 05/31/01 & NF & 1 & 1 & 47080 & - & - & - & - & - \\
\hline Silver & 3 & 915 & $05 / 31 / 01$ & $\mathrm{~F}$ & 1 & 0 & - & {$[0.57]$} & 100 & $0 / 1$ & 50 & $0 / 1$ \\
\hline Silver & 3 & 915 & 05/31/01 & NF & 1 & 1 & 0.69 & - & - & - & - & - \\
\hline Sodium & 3 & 915 & 05/31/01 & $\mathrm{F}$ & 1 & 1 & 9400 & - & - & - & - & - \\
\hline Sodium & 3 & 915 & $05 / 31 / 01$ & NF & 1 & 1 & 9200 & - & - & - & - & - \\
\hline Strontium & 3 & 915 & $05 / 31 / 01$ & $\mathrm{~F}$ & 1 & 1 & 160 & - & - & - & - & - \\
\hline Strontium & 3 & 915 & 05/31/01 & NF & 1 & 1 & 160 & - & - & - & - & - \\
\hline Sulfate & 3 & 915 & 05/31/01 & $\mathrm{F}$ & 1 & 0 & - & [1000] & 250000 & $0 / 1$ & 600000 & $0 / 1$ \\
\hline Thallium & 3 & 915 & 05/31/01 & $\mathrm{F}$ & 1 & 1 & 0.54 & - & 2 & $0 / 1$ & - & - \\
\hline Thallium & 3 & 915 & $05 / 31 / 01$ & NF & 1 & 0 & - & {$[0.077]$} & - & - & - & - \\
\hline $\begin{array}{l}\text { Total Kjeldahl } \\
\text { Nitrogen }\end{array}$ & 3 & 915 & 05/31/01 & NF & 1 & 1 & 1700 & - & - & - & - & - \\
\hline $\begin{array}{l}\text { Total Kjeldahl } \\
\text { Nitrogen }\end{array}$ & 3 & 915 & 05/31/01 & $\mathrm{F}$ & 1 & 1 & 1600 & - & - & - & - & - \\
\hline Uranium & 3 & 915 & $05 / 31 / 01$ & $\mathrm{~F}$ & 1 & 1 & 0.084 & - & - & - & - & - \\
\hline Uranium & 3 & 915 & 05/31/01 & $\mathrm{NF}$ & 1 & 1 & 0.065 & - & - & - & - & - \\
\hline Vanadium & 3 & 915 & 05/31/01 & $\mathrm{F}$ & 1 & 0 & - & {$[0.38]$} & - & - & - & - \\
\hline Vanadium & 3 & 915 & 05/31/01 & NF & 1 & 0 & - & {$[0.38]$} & - & - & - & - \\
\hline
\end{tabular}


Table A-2 (continued)

\begin{tabular}{|c|c|c|c|c|c|c|c|c|c|c|c|c|}
\hline $\begin{array}{l}\text { Parameter } \\
\text { and } \\
\text { Analyte }\end{array}$ & Screen & $\begin{array}{l}\text { Depth } \\
(\mathrm{ft})^{\mathrm{a}}\end{array}$ & $\begin{array}{c}\text { Collection } \\
\text { Date }\end{array}$ & $\begin{array}{c}\text { Field } \\
\text { Preparation }\end{array}$ & $\begin{array}{l}\text { Number } \\
\text { of } \\
\text { Analyses }\end{array}$ & $\begin{array}{c}\text { Number } \\
\text { of } \\
\text { Detects }\end{array}$ & $\begin{array}{c}\text { Detected } \\
\text { Value } \\
\text { ( } \mu \mathrm{g} / \mathrm{L})\end{array}$ & $\begin{array}{l}\text { Non- } \\
\text { detected } \\
\text { Value } \\
(\mu \mathrm{g} / \mathrm{L})\end{array}$ & $\begin{array}{l}\text { Drinking } \\
\text { Water } \\
\text { MCL }^{\mathrm{b}} \\
(\mu \mathrm{g} / \mathrm{L})\end{array}$ & $\begin{array}{l}\text { Frequency } \\
\text { of Detects } \\
>\text { Drinking } \\
\text { Water MCL }\end{array}$ & $\begin{array}{c}\text { NMED }^{c} \\
\text { Groundwater } \\
\text { Standard }^{\mathrm{d}} \\
(\mu \mathrm{g} / \mathrm{L})\end{array}$ & $\begin{array}{l}\text { Frequency of } \\
\text { Detects }>\text { NMED } \\
\text { Groundwater } \\
\text { Standard }\end{array}$ \\
\hline Zinc & 3 & 915 & 05/31/01 & $\mathrm{F}$ & 1 & 1 & 320 & - & 5000 & $0 / 1$ & 10000 & $0 / 1$ \\
\hline Zinc & 3 & 915 & 05/31/01 & NF & 1 & 1 & 370 & - & - & - & - & - \\
\hline \multicolumn{13}{|c|}{ Stable Isotope (\%o) } \\
\hline$\delta \mathrm{D}$ & 3 & 915 & 05/31/01 & NF & 1 & 1 & -79 & - & - & - & - & - \\
\hline$\delta^{18} \mathrm{O}$ & 3 & 915 & $05 / 31 / 01$ & NF & 1 & 1 & -11.4 & - & - & - & - & - \\
\hline
\end{tabular}

a The static water level for the regional aquifer at R-7 was $902.8 \mathrm{ft}$ when the well was drilled.

${ }^{\mathrm{b}} \mathrm{MCL}=$ Maximum contaminant level. US Environmental Protection Agency (EPA) MCLs are from the National Primary Water Regulations, 40 CFR Part 141. US EPA secondary MCLs are from National Secondary Drinking Water Regulations, 20 NMAC 7.1.

${ }^{c}$ NMED $=$ New Mexico Environment Department.

d State of New Mexico groundwater standards are from New Mexico Quality Control Commission Regulations, Ground and Surface Water Protection, 20 NMAC 6.2.

${ }^{\mathrm{e}} \mathrm{NF}=$ Nonfiltered.

${ }^{f}-=$ Not available or applicable

$\underset{\infty}{>} \quad \mathrm{g}$ NTU $=$ Nephelometric turbidity unit.

${ }^{\mathrm{h}} \mathrm{F}=$ Filtered. 
Table A-3

Regional Well R-7 Screen 1 First Round Sample Results: Data Summary for Detected Organic Chemicals

\begin{tabular}{|c|c|c|c|c|c|c|c|c|c|c|c|c|}
\hline $\begin{array}{l}\text { Parameter } \\
\text { and } \\
\text { Analyte }\end{array}$ & Screen & $\begin{array}{l}\text { Depth } \\
(\mathrm{ft})^{\mathrm{a}}\end{array}$ & $\begin{array}{c}\text { Collection } \\
\text { Date }\end{array}$ & $\begin{array}{c}\text { Field } \\
\text { Preparation }\end{array}$ & $\begin{array}{l}\text { Number } \\
\text { of } \\
\text { Analyses }\end{array}$ & $\begin{array}{c}\text { Number } \\
\text { of } \\
\text { Detects }\end{array}$ & $\begin{array}{c}\text { Detected } \\
\text { Value } \\
\text { ( } \mu \mathrm{g} / \mathrm{L})\end{array}$ & $\begin{array}{l}\text { Non- } \\
\text { detected } \\
\text { Value } \\
(\mu \mathrm{g} / \mathrm{L})\end{array}$ & $\begin{array}{l}\text { Drinking } \\
\text { Water } \\
M L^{b} \\
(\mu g / L)\end{array}$ & $\begin{array}{l}\text { Frequency } \\
\text { of Detects } \\
\text { > Drinking } \\
\text { Water MCL }\end{array}$ & $\begin{array}{c}\text { NMED }^{c} \\
\text { Groundwater } \\
\text { Standard }^{\mathrm{d}} \\
(\mu \mathrm{g} / \mathrm{L})\end{array}$ & $\begin{array}{l}\text { Frequency of } \\
\text { Detects }>\text { NMED } \\
\text { Groundwater } \\
\text { Standard }\end{array}$ \\
\hline $\begin{array}{l}\text { Dissolved Organic } \\
\text { Carbon }\end{array}$ & 1 & 378 & 05/30/01 & $\mathrm{F}^{\mathrm{e}}$ & 1 & 1 & 2200 & $-^{f}$ & - & - & - & - \\
\hline $\begin{array}{l}\text { Humic Substances, } \\
\text { Hydrophilic Acids }\end{array}$ & 1 & 378 & 05/30/01 & $F$ & 1 & 1 & 300 & - & - & - & - & - \\
\hline $\begin{array}{l}\text { Humic Substances, } \\
\text { Hydrophilic Bases }\end{array}$ & 1 & 378 & 05/30/01 & $F$ & 1 & 1 & - & [100] & - & - & - & - \\
\hline $\begin{array}{l}\text { Humic Substances, } \\
\text { Hydrophilic Neutrals }\end{array}$ & 1 & 378 & 05/30/01 & $F$ & 1 & 1 & 400 & - & - & - & - & - \\
\hline $\begin{array}{l}\text { Humic Substances, } \\
\text { Hydrophilic Total }\end{array}$ & 1 & 378 & 05/30/01 & $\mathrm{F}$ & 1 & 1 & 700 & - & - & - & - & - \\
\hline $\begin{array}{l}\text { Humic Substances, } \\
\text { Hydrophobic Acids }\end{array}$ & 1 & 378 & 05/30/01 & $F$ & 1 & 1 & 1000 & - & - & - & - & - \\
\hline $\begin{array}{l}\text { Humic Substances, } \\
\text { Hydrophobic Bases }\end{array}$ & 1 & 378 & 05/30/01 & $\mathrm{F}$ & 1 & 1 & - & [100] & - & - & - & - \\
\hline $\begin{array}{l}\text { Humic Substances, } \\
\text { Hydrophobic Neutrals }\end{array}$ & 1 & 378 & 05/30/01 & $\mathrm{F}$ & 1 & 1 & 500 & - & - & - & - & - \\
\hline $\begin{array}{l}\text { Humic Substances, } \\
\text { Hydrophobic Total }\end{array}$ & 1 & 378 & 05/30/01 & $\mathrm{F}$ & 1 & 1 & 1500 & - & - & - & - & - \\
\hline Total Organic Carbon & 1 & 378 & $05 / 30 / 01$ & $N F^{g}$ & 1 & 1 & 2600 & - & - & - & - & - \\
\hline
\end{tabular}

a The static water level for the regional aquifer at R-7 was $902.8 \mathrm{ft}$ when the well was drilled.

${ }^{\mathrm{b}} \mathrm{MCL}=$ Maximum contaminant level. US Environmental Protection Agency (EPA) MCLs are from the National Primary Water Regulations, 40 CFR Part 141. US EPA secondary MCLs are from National Secondary Drinking Water Regulations, 20 NMAC 7.1.

${ }^{c}$ NMED $=$ New Mexico Environment Department.

${ }^{\mathrm{d}}$ State of New Mexico groundwater standards are from New Mexico Quality Control Commission Regulations, Ground and Surface Water Protection, 20 NMAC 6.2.

$\mathrm{e}=$ Filtered.

f $-=$ Not available or applicable

${ }^{\mathrm{g}} \mathrm{NF}=$ Nonfiltered. 
Table A-4

Regional Well R-7 Screen 3 First Round Sample Results: Data Summary for Detected Organic Chemicals

\begin{tabular}{|c|c|c|c|c|c|c|c|c|c|c|c|c|}
\hline $\begin{array}{c}\text { Parameter } \\
\text { and } \\
\text { Analyte }\end{array}$ & Screen & $\begin{array}{c}\text { Depth } \\
(\mathrm{ft})^{\mathrm{a}}\end{array}$ & $\begin{array}{l}\text { Collection } \\
\text { Date }\end{array}$ & $\begin{array}{c}\text { Field } \\
\text { Preparation }\end{array}$ & $\begin{array}{c}\text { Number } \\
\text { of } \\
\text { Analyses }\end{array}$ & $\begin{array}{c}\text { Number } \\
\text { of } \\
\text { Detects }\end{array}$ & $\begin{array}{c}\text { Detected } \\
\text { Value } \\
(\mu \mathrm{g} / \mathrm{L})\end{array}$ & $\begin{array}{c}\text { Non- } \\
\text { detected } \\
\text { Value } \\
(\mu \mathrm{g} / \mathrm{L})\end{array}$ & $\begin{array}{l}\text { Drinking } \\
\text { Water } \\
M^{\prime} C^{b} \\
(\mu g / L)\end{array}$ & $\begin{array}{l}\text { Frequency } \\
\text { of Detects } \\
>\text { Drinking } \\
\text { Water MCL }\end{array}$ & $\begin{array}{c}\text { NMED }^{c} \\
\text { Groundwater } \\
\text { Standard }^{d} \\
(\mu \mathrm{g} / \mathrm{L})\end{array}$ & $\begin{array}{c}\text { Frequency of } \\
\text { Detects }>\text { NMED } \\
\text { Groundwater } \\
\text { Standard }\end{array}$ \\
\hline Acetone & 3 & 915 & $05 / 31 / 01$ & $\mathrm{NF}^{\mathrm{e}}$ & 1 & 1 & 51 & $-^{f}$ & - & - & - & - \\
\hline Benzoic Acid & 3 & 915 & $05 / 31 / 01$ & $\mathrm{NF}$ & 1 & 1 & 13 & - & - & - & - & - \\
\hline $\begin{array}{l}\text { Dissolved Organic } \\
\text { Carbon }\end{array}$ & 3 & 915 & 05/31/01 & $\mathrm{F}^{\mathrm{g}}$ & 1 & 1 & 8300 & - & - & - & - & - \\
\hline $\begin{array}{l}\text { Humic Substances, } \\
\text { Hydrophilic Acids }\end{array}$ & 3 & 915 & $05 / 31 / 01$ & $\mathrm{~F}$ & 1 & 1 & 2300 & - & 一 & - & - & - \\
\hline $\begin{array}{l}\text { Humic Substances, } \\
\text { Hydrophilic Bases }\end{array}$ & 3 & 915 & $05 / 31 / 01$ & $\mathrm{~F}$ & 1 & 1 & - & [100] & - & - & - & - \\
\hline $\begin{array}{l}\text { Humic Substances, } \\
\text { Hydrophilic Neutrals }\end{array}$ & 3 & 915 & $05 / 31 / 01$ & $\mathrm{~F}$ & 1 & 1 & 1900 & - & - & - & - & - \\
\hline $\begin{array}{l}\text { Humic Substances, } \\
\text { Hydrophilic Total }\end{array}$ & 3 & 915 & $05 / 31 / 01$ & $\mathrm{~F}$ & 1 & 1 & 4100 & - & - & - & - & - \\
\hline $\begin{array}{l}\text { Humic Substances, } \\
\text { Hydrophobic Acids }\end{array}$ & 3 & 915 & $05 / 31 / 01$ & $\mathrm{~F}$ & 1 & 1 & 2500 & - & 一 & - & - & - \\
\hline $\begin{array}{l}\text { Humic Substances, } \\
\text { Hydrophobic Bases }\end{array}$ & 3 & 915 & $05 / 31 / 01$ & $\mathrm{~F}$ & 1 & 1 & 100 & - & - & - & - & - \\
\hline $\begin{array}{l}\text { Humic Substances, } \\
\text { Hydrophobic Neutrals }\end{array}$ & 3 & 915 & $05 / 31 / 01$ & $\mathrm{~F}$ & 1 & 1 & 1600 & - & - & - & - & - \\
\hline $\begin{array}{l}\text { Humic Substances, } \\
\text { Hydrophobic Total }\end{array}$ & 3 & 915 & $05 / 31 / 01$ & $\mathrm{~F}$ & 1 & 1 & 4200 & - & - & - & - & - \\
\hline Methylphenol[4-] & 3 & 915 & $05 / 31 / 01$ & $\mathrm{NF}$ & 1 & 1 & 58 & - & - & - & - & - \\
\hline Phenol & 3 & 915 & $05 / 31 / 01$ & $\mathrm{NF}$ & 1 & 1 & 11 & - & - & - & - & - \\
\hline Total Organic Carbon & 3 & 915 & $05 / 31 / 01$ & $\mathrm{NF}$ & 1 & 1 & 13000 & - & - & - & - & - \\
\hline
\end{tabular}

${ }^{a}$ The static water level for the regional aquifer at R-7 was $902.8 \mathrm{ft}$ when the well was drilled.

${ }^{\mathrm{b}} \mathrm{MCL}=$ Maximum contaminant level. US Environmental Protection Agency (EPA) MCLs are from the National Primary Water Regulations, 40 CFR Part 141. US EPA secondary MCLs are from National Secondary Drinking Water Regulations, 20 NMAC 7.1.

${ }^{c}$ NMED = New Mexico Environment Department.

${ }^{d}$ State of New Mexico groundwater standards are from New Mexico Quality Control Commission Regulations, Ground and Surface Water Protection, 20 NMAC 6.2.

$\mathrm{NF}=$ Nonfiltered.

$\mathrm{f}-=$ Not available or applicable.

${ }^{\mathrm{g}} \mathrm{F}=$ Filtered. 
Table A-5

Regional Well R-7 Screen 1 First Round Sample Results: Data Summary for Radionuclides

\begin{tabular}{|c|c|c|c|c|c|c|c|c|c|c|}
\hline $\begin{array}{l}\text { Parameter } \\
\text { and } \\
\text { Analyte }\end{array}$ & Screen & $\begin{array}{c}\text { Depth } \\
(\mathrm{ft})^{\mathrm{a}}\end{array}$ & $\begin{array}{l}\text { Collection } \\
\text { Date }\end{array}$ & $\begin{array}{c}\text { Field } \\
\text { Preparation }\end{array}$ & $\begin{array}{l}\text { Number } \\
\text { of } \\
\text { Analyses }\end{array}$ & $\begin{array}{c}\text { Number } \\
\text { of } \\
\text { Detects }\end{array}$ & $\begin{array}{l}\text { Detected } \\
\text { Value } \\
\text { (pCi/L) }\end{array}$ & $\begin{array}{c}\text { Nondetected } \\
\text { Value } \\
\text { (pCi/L) }\end{array}$ & $\begin{array}{c}\text { Drinking } \\
\text { Water MCL } \\
(p C i / L)\end{array}$ & $\begin{array}{c}\text { Frequency of } \\
\text { Detects > Drinking } \\
\text { Water MCL }\end{array}$ \\
\hline Americium-241 & 1 & 378 & 05/30/01 & $\mathrm{F}^{\mathrm{c}}$ & 1 & 0 & $-^{d}$ & [0.009] & $15^{\mathrm{e}}$ & $0 / 1$ \\
\hline Americium-241 & 1 & 378 & 05/30/01 & $\mathrm{NF}^{\mathrm{f}}$ & 1 & 0 & - & {$[0.009]$} & - & - \\
\hline Cesium-134 & 1 & 378 & 05/30/01 & $\mathrm{F}$ & 1 & 0 & - & {$[-2]$} & - & - \\
\hline Cesium-134 & 1 & 378 & 05/30/01 & NF & 1 & 0 & - & {$[-1.6]$} & - & - \\
\hline Cesium-137 & 1 & 378 & 05/30/01 & $\mathrm{F}$ & 1 & 0 & - & {$[0.1]$} & - & - \\
\hline Cesium-137 & 1 & 378 & 05/30/01 & NF & 1 & 0 & - & {$[0.1]$} & - & - \\
\hline Cobalt-60 & 1 & 378 & $05 / 30 / 01$ & $\mathrm{~F}$ & 1 & 0 & - & {$[-1.2]$} & - & - \\
\hline Cobalt-60 & 1 & 378 & 05/30/01 & NF & 1 & 0 & - & {$[0.7]$} & - & - \\
\hline Europium-152 & 1 & 378 & 05/30/01 & $\mathrm{F}$ & 1 & 0 & - & [21] & - & - \\
\hline Europium-152 & 1 & 378 & 05/30/01 & NF & 1 & 0 & - & {$[-2]$} & - & - \\
\hline Gross Alpha Radiation & 1 & 378 & 05/30/01 & NF & 1 & 0 & - & {$[0.31]$} & - & - \\
\hline Gross Beta Radiation & 1 & 378 & 05/30/01 & NF & 1 & 1 & 3.8 & - & - & - \\
\hline Gross Gamma Radiation & 1 & 378 & 05/30/01 & NF & 1 & 1 & 181 & - & - & - \\
\hline Plutonium-238 & 1 & 378 & 05/30/01 & $\mathrm{F}$ & 1 & 0 & - & {$[0.002]$} & $15^{\mathrm{e}}$ & $0 / 1$ \\
\hline Plutonium-238 & 1 & 378 & 05/30/01 & NF & 1 & 0 & - & [0.001] & - & - \\
\hline Plutonium-239 & 1 & 378 & 05/30/01 & $\mathrm{F}$ & 1 & 0 & - & {$[0.01]$} & $15^{\mathrm{e}}$ & $0 / 1$ \\
\hline Plutonium-239 & 1 & 378 & 05/30/01 & NF & 1 & 0 & - & {$[0.003]$} & - & - \\
\hline Ruthenium-106 & 1 & 378 & 05/30/01 & $\mathrm{F}$ & 1 & 0 & - & [1] & - & - \\
\hline Ruthenium-106 & 1 & 378 & 05/30/01 & NF & 1 & 0 & - & {$[-5]$} & - & - \\
\hline Sodium-22 & 1 & 378 & 05/30/01 & $\mathrm{F}$ & 1 & 0 & - & {$[-0.3]$} & - & - \\
\hline Sodium-22 & 1 & 378 & 05/30/01 & NF & 1 & 0 & - & [1.3] & - & - \\
\hline Strontium-90 & 1 & 378 & 05/30/01 & $\mathrm{F}$ & 1 & 0 & - & {$[0]$} & 8 & $0 / 1$ \\
\hline Strontium-90 & 1 & 378 & 05/30/01 & NF & 1 & 0 & - & {$[-0.1]$} & - & - \\
\hline Technetium-99 & 1 & 378 & 05/30/01 & NF & 1 & 0 & - & [1.1] & - & - \\
\hline Tritium & 1 & 378 & 05/30/01 & NF & 1 & 1 & 2.55 & - & 20000 & $0 / 1$ \\
\hline Uranium-234 & 1 & 378 & 05/30/01 & $\mathrm{F}$ & 1 & 0 & - & [0.071] & - & - \\
\hline Uranium-234 & 1 & 378 & 05/30/01 & NF & 1 & 0 & - & {$[0.154]$} & - & - \\
\hline
\end{tabular}


Table A-5 (continued)

\begin{tabular}{|c|c|c|c|c|c|c|c|c|c|c|}
\hline $\begin{array}{l}\text { Parameter } \\
\text { and } \\
\text { Analyte }\end{array}$ & Screen & $\begin{array}{l}\text { Depth } \\
(\mathrm{ft})^{a}\end{array}$ & $\begin{array}{l}\text { Collection } \\
\text { Date }\end{array}$ & $\begin{array}{c}\text { Field } \\
\text { Preparation }\end{array}$ & $\begin{array}{l}\text { Number } \\
\text { of } \\
\text { Analyses }\end{array}$ & $\begin{array}{l}\text { Number } \\
\text { of } \\
\text { Detects }\end{array}$ & $\begin{array}{l}\text { Detected } \\
\text { Value } \\
\text { (pCi/L) }\end{array}$ & $\begin{array}{l}\text { Nondetected } \\
\text { Value } \\
\text { (pCi/L) }\end{array}$ & $\begin{array}{c}\text { Drinking } \\
\text { Water MCL } \\
\text { (pCi/L) }\end{array}$ & $\begin{array}{c}\text { Frequency of } \\
\text { Detects > Drinking } \\
\text { Water MCL }\end{array}$ \\
\hline Uranium-235 & 1 & 378 & 05/30/01 & $\mathrm{F}$ & 1 & 0 & - & {$[0.005]$} & - & - \\
\hline Uranium-235 & 1 & 378 & 05/30/01 & NF & 1 & 0 & - & [0.025] & - & - \\
\hline Uranium-238 & 1 & 378 & 05/30/01 & $\mathrm{F}$ & 1 & 0 & - & {$[0.037]$} & - & - \\
\hline Uranium-238 & 1 & 378 & 05/30/01 & NF & 1 & 0 & - & {$[0.044]$} & - & - \\
\hline
\end{tabular}

${ }^{a}$ The static water level for the regional aquifer at R-7 was $902.8 \mathrm{ft}$ when the well was drilled.

${ }^{\mathrm{b}} \mathrm{MCL}=$ Maximum contaminant level. US Environmental Protection Agency (EPA) MCLs are from the National Primary Water Regulations, 40 CFR Part 141. US EPA secondary MCLs are from National Secondary Drinking Water Regulations, 20 NMAC 7.1.

${ }^{c} \mathrm{~F}=$ Filtered.

d $-=$ Not available or applicable.

Based on an $M C L$ of $15 \mathrm{pCi} / \mathrm{L}$ for gross alpha particle activity (including radium, but excluding radon and uranium).

${ }^{\mathrm{f}} \mathrm{NF}=$ Nonfiltered. 
Table A-6

Regional Well R-7 Screen 3 First Round Sample Results: Data Summary for Radionuclides

\begin{tabular}{|c|c|c|c|c|c|c|c|c|c|c|}
\hline $\begin{array}{l}\text { Parameter } \\
\text { and } \\
\text { Analyte }\end{array}$ & Screen & $\begin{array}{c}\text { Depth } \\
(\mathrm{ft})^{\mathrm{a}}\end{array}$ & $\begin{array}{l}\text { Collection } \\
\text { Date }\end{array}$ & $\begin{array}{c}\text { Field } \\
\text { Preparation }\end{array}$ & $\begin{array}{l}\text { Number } \\
\text { of } \\
\text { Analyses }\end{array}$ & $\begin{array}{l}\text { Number } \\
\text { of } \\
\text { Detects }\end{array}$ & $\begin{array}{l}\text { Detected } \\
\text { Value } \\
\text { (pCi/L) }\end{array}$ & $\begin{array}{c}\text { Nondetected } \\
\text { Value } \\
\text { (pCi/L) }\end{array}$ & $\begin{array}{c}\text { Drinking } \\
\text { Water MCL } \\
(p C i / L)\end{array}$ & $\begin{array}{c}\text { Frequency of } \\
\text { Detects > Drinking } \\
\text { Water MCL }\end{array}$ \\
\hline Americium-241 & 3 & 915 & $05 / 31 / 01$ & $\mathrm{~F}^{\mathrm{c}}$ & 1 & 0 & $-^{d}$ & {$[0.022]$} & $15^{\mathrm{e}}$ & $0 / 1$ \\
\hline Americium-241 & 3 & 915 & $05 / 31 / 01$ & $\mathrm{NF}^{\mathrm{f}}$ & 1 & 0 & - & {$[0.006]$} & - & - \\
\hline Cesium-134 & 3 & 915 & 05/31/01 & $\mathrm{F}$ & 1 & 0 & - & {$[-0.8]$} & - & - \\
\hline Cesium-134 & 3 & 915 & $05 / 31 / 01$ & NF & 1 & 0 & - & {$[-3.7]$} & - & - \\
\hline Cesium-137 & 3 & 915 & $05 / 31 / 01$ & $\mathrm{~F}$ & 1 & 0 & - & {$[-0.1]$} & - & - \\
\hline Cesium-137 & 3 & 915 & 05/31/01 & NF & 1 & 0 & - & {$[-4.7]$} & - & - \\
\hline Cobalt-60 & 3 & 915 & $05 / 31 / 01$ & $\mathrm{~F}$ & 1 & 0 & - & {$[0.2]$} & - & - \\
\hline Cobalt-60 & 3 & 915 & $05 / 31 / 01$ & NF & 1 & 0 & - & [1.7] & - & - \\
\hline Europium-152 & 3 & 915 & $05 / 31 / 01$ & $\mathrm{~F}$ & 1 & 0 & - & {$[-20]$} & - & - \\
\hline Europium-152 & 3 & 915 & $05 / 31 / 01$ & NF & 1 & 0 & - & [13] & - & - \\
\hline Gross Alpha Radiation & 3 & 915 & 05/31/01 & NF & 1 & 1 & 2 & - & - & - \\
\hline Gross Beta Radiation & 3 & 915 & $05 / 31 / 01$ & NF & 1 & 1 & 4.3 & - & - & - \\
\hline Gross Gamma Radiation & 3 & 915 & $05 / 31 / 01$ & NF & 1 & 1 & 152 & - & - & - \\
\hline Plutonium-238 & 3 & 915 & 05/31/01 & $\mathrm{F}$ & 1 & 0 & - & {$[-0.002]$} & $15^{\mathrm{e}}$ & $0 / 1$ \\
\hline Plutonium-238 & 3 & 915 & $05 / 31 / 01$ & NF & 1 & 0 & - & [0.003] & - & - \\
\hline Plutonium-239 & 3 & 915 & 05/31/01 & $\mathrm{F}$ & 1 & 0 & - & {$[0.017]$} & $15^{\mathrm{e}}$ & $0 / 1$ \\
\hline Plutonium-239 & 3 & 915 & $05 / 31 / 01$ & NF & 1 & 0 & - & {$[0.003]$} & - & - \\
\hline Ruthenium-106 & 3 & 915 & $05 / 31 / 01$ & $\mathrm{~F}$ & 1 & 0 & - & {$[-5]$} & - & - \\
\hline Ruthenium-106 & 3 & 915 & $05 / 31 / 01$ & NF & 1 & 0 & - & {$[-18]$} & - & - \\
\hline Sodium-22 & 3 & 915 & 05/31/01 & $\mathrm{F}$ & 1 & 0 & - & {$[1.7]$} & - & - \\
\hline Sodium-22 & 3 & 915 & $05 / 31 / 01$ & NF & 1 & 0 & - & {$[-0.9]$} & - & - \\
\hline Strontium-90 & 3 & 915 & $05 / 31 / 01$ & $\mathrm{~F}$ & 1 & 0 & - & [1.4] & 8 & $0 / 1$ \\
\hline Strontium-90 & 3 & 915 & $05 / 31 / 01$ & NF & 1 & 0 & - & {$[0.6]$} & - & - \\
\hline Technetium-99 & 3 & 915 & $05 / 31 / 01$ & NF & 1 & 0 & - & {$[0.02]$} & - & - \\
\hline Tritium & 3 & 915 & 05/31/01 & NF & 1 & 1 & 2.52 & - & 20000 & $0 / 1$ \\
\hline Uranium-234 & 3 & 915 & 05/31/01 & $\mathrm{F}$ & 1 & 0 & - & {$[0.058]$} & - & - \\
\hline Uranium-234 & 3 & 915 & $05 / 31 / 01$ & NF & 1 & 0 & - & {$[0.026]$} & - & - \\
\hline
\end{tabular}


Table A-6 (continued)

\begin{tabular}{|c|c|c|c|c|c|c|c|c|c|c|}
\hline $\begin{array}{l}\text { Parameter } \\
\text { and } \\
\text { Analyte }\end{array}$ & Screen & $\begin{array}{l}\text { Depth } \\
(\mathrm{ft})^{a}\end{array}$ & $\begin{array}{l}\text { Collection } \\
\text { Date }\end{array}$ & $\begin{array}{c}\text { Field } \\
\text { Preparation }\end{array}$ & $\begin{array}{l}\text { Number } \\
\text { of } \\
\text { Analyses }\end{array}$ & $\begin{array}{l}\text { Number } \\
\text { of } \\
\text { Detects }\end{array}$ & $\begin{array}{l}\text { Detected } \\
\text { Value } \\
\text { (pCi/L) }\end{array}$ & $\begin{array}{l}\text { Nondetected } \\
\text { Value } \\
\text { (pCi/L) }\end{array}$ & $\begin{array}{c}\text { Drinking } \\
\text { Water MCL } \\
\text { (pCi/L) }\end{array}$ & $\begin{array}{c}\text { Frequency of } \\
\text { Detects > Drinking } \\
\text { Water MCL }\end{array}$ \\
\hline Uranium-235 & 3 & 915 & 05/31/01 & $\mathrm{F}$ & 1 & 0 & - & {$[0.009]$} & - & - \\
\hline Uranium-235 & 3 & 915 & 05/31/01 & NF & 1 & 0 & - & [0.013] & - & - \\
\hline Uranium-238 & 3 & 915 & $05 / 31 / 01$ & $\mathrm{~F}$ & 1 & 1 & 0.07 & - & - & - \\
\hline Uranium-238 & 3 & 915 & $05 / 31 / 01$ & NF & 1 & 0 & - & {$[0.021]$} & - & - \\
\hline
\end{tabular}

${ }^{a}$ The static water level for the regional aquifer at R-7 was $902.8 \mathrm{ft}$ when the well was drilled.

${ }^{\mathrm{b}} \mathrm{MCL}=$ Maximum contaminant level. US Environmental Protection Agency (EPA) MCLs are from the National Primary Water Regulations, 40 CFR Part 141. US EPA secondary MCLs are from National Secondary Drinking Water Regulations, 20 NMAC 7.1.

${ }^{c} \mathrm{~F}=$ Filtered.

d $-=$ Not available or applicable.

Based on an $M C L$ of $15 \mathrm{pCi} / \mathrm{L}$ for gross alpha particle activity (including radium, but excluding radon and uranium).

${ }^{\mathrm{f}} \mathrm{NF}=$ Nonfiltered. 
Table A-7

Regional Well R-7 Screen 1 Second Round Sample Results: Data Summary for Inorganic Chemicals

\begin{tabular}{|c|c|c|c|c|c|c|c|c|c|c|c|c|}
\hline $\begin{array}{l}\text { Parameter } \\
\text { and } \\
\text { Analyte }\end{array}$ & Screen & $\begin{array}{l}\text { Depth } \\
(\mathrm{ft})^{\mathrm{a}}\end{array}$ & $\begin{array}{l}\text { Collection } \\
\text { Date }\end{array}$ & $\begin{array}{c}\text { Field } \\
\text { Preparation }\end{array}$ & $\begin{array}{c}\text { Number } \\
\text { of } \\
\text { Analyses }\end{array}$ & $\begin{array}{c}\text { Number } \\
\text { of } \\
\text { Detects }\end{array}$ & $\begin{array}{c}\text { Detected } \\
\text { Value } \\
\text { ( } \mu \mathrm{g} / \mathrm{L})\end{array}$ & $\begin{array}{c}\text { Non- } \\
\text { detected } \\
\text { Value } \\
(\mu \mathrm{g} / \mathrm{L})\end{array}$ & $\begin{array}{l}\text { Drinking } \\
\text { Water } \\
M C L^{b} \\
(\mu g / L)\end{array}$ & $\begin{array}{l}\text { Frequency } \\
\text { of Detects } \\
>\text { Drinking } \\
\text { Water MCL }\end{array}$ & $\begin{array}{c}\text { NMED }^{c} \\
\text { Groundwater } \\
\text { Standard }^{\mathrm{d}} \\
(\mu \mathrm{g} / \mathrm{L})\end{array}$ & $\begin{array}{l}\text { Frequency of } \\
\text { Detects }>\text { NMED } \\
\text { Groundwater } \\
\text { Standard }\end{array}$ \\
\hline \multicolumn{13}{|l|}{ Field Parameter } \\
\hline $\begin{array}{l}\text { Field Alkalinity (total } \\
\text { as } \mathrm{CaCO}_{3} \text { ) }\end{array}$ & 1 & 378 & 08/08/01 & $\mathrm{NF}^{\mathrm{e}}$ & 1 & 1 & 13000 & $-^{f}$ & - & - & - & - \\
\hline Dissolved Oxygen & 1 & 378 & 08/08/01 & NF & 1 & 1 & - & - & - & - & - & - \\
\hline $\mathrm{pH}$ & 1 & 378 & 08/08/01 & NF & 1 & 1 & 7.18 & - & $>6 \&<9$ & $0 / 1$ & $>6 \&<9$ & $0 / 1$ \\
\hline $\begin{array}{l}\text { Specific Conductance } \\
(\mu \mathrm{S} / \mathrm{cm})\end{array}$ & 1 & 378 & 08/08/01 & NF & 1 & 1 & 75.6 & - & - & $0 / 1$ & - & $0 / 1$ \\
\hline Temperature $\left({ }^{\circ} \mathrm{C}\right)$ & 1 & 378 & 08/08/01 & NF & 1 & 1 & 14.3 & - & - & $0 / 1$ & - & $0 / 1$ \\
\hline Turbidity (NTU9) & 1 & 378 & 08/08/01 & NF & 1 & 1 & 1.0 & - & - & $0 / 1$ & - & $0 / 1$ \\
\hline \multicolumn{13}{|l|}{ Analyte } \\
\hline $\begin{array}{l}\text { Lab Alkalinity (total as } \\
\mathrm{CaCO}_{3} \text { ) }\end{array}$ & 1 & 378 & 08/08/01 & $\mathrm{F}^{\mathrm{h}}$ & 1 & 1 & 46000 & - & - & - & - & - \\
\hline Aluminum & 1 & 378 & 08/08/01 & $\mathrm{F}$ & 1 & 1 & 54 & - & 50 & $1 / 1$ & 5000 & $0 / 1$ \\
\hline Aluminum & 1 & 378 & $08 / 08 / 01$ & $\mathrm{NF}$ & 1 & 1 & 71 & - & - & - & - & - \\
\hline Ammonia (as N) & 1 & 378 & $08 / 08 / 01$ & $\mathrm{~F}$ & 1 & 0 & - & [100] & - & - & - & - \\
\hline Antimony & 1 & 378 & 08/08/01 & $\mathrm{F}$ & 1 & 0 & - & {$[0.355]$} & 6 & $0 / 2$ & - & - \\
\hline Antimony & 1 & 378 & 08/08/01 & $\mathrm{NF}$ & 1 & 0 & - & [0.043] & - & - & - & - \\
\hline Arsenic & 1 & 378 & 08/08/01 & $\mathrm{F}$ & 1 & 0 & - & [2] & 50 & $0 / 1$ & 100 & $0 / 1$ \\
\hline Arsenic & 1 & 378 & 08/08/01 & NF & 1 & 0 & - & [2] & - & - & - & - \\
\hline Barium & 1 & 378 & 08/08/01 & $\mathrm{F}$ & 1 & 1 & 84 & - & 2000 & $0 / 1$ & 1000 & $0 / 1$ \\
\hline Barium & 1 & 378 & 08/08/01 & NF & 1 & 1 & 91 & - & - & - & - & - \\
\hline Beryllium & 1 & 378 & 08/08/01 & $\mathrm{F}$ & 1 & 1 & 0.138 & - & 4 & $0 / 2$ & - & - \\
\hline Beryllium & 1 & 378 & $08 / 08 / 01$ & $\mathrm{NF}$ & 1 & 1 & 0.007 & - & - & - & - & - \\
\hline Boron & 1 & 378 & 08/08/01 & $\mathrm{F}$ & 1 & 0 & - & [16] & - & - & 750 & $0 / 1$ \\
\hline Boron & 1 & 378 & 08/08/01 & $\mathrm{NF}$ & 1 & 0 & - & [17] & - & - & - & - \\
\hline Bromide & 1 & 378 & 08/08/01 & $\mathrm{F}$ & 1 & 0 & - & [200] & - & - & - & - \\
\hline Cadmium & 1 & 378 & 08/08/01 & $\mathrm{F}$ & 1 & 1 & 0.221 & - & 5 & $0 / 2$ & 10 & $0 / 2$ \\
\hline
\end{tabular}


Table A-7 (continued)

\begin{tabular}{|c|c|c|c|c|c|c|c|c|c|c|c|c|}
\hline $\begin{array}{l}\text { Parameter } \\
\text { and } \\
\text { Analyte }\end{array}$ & Screen & $\begin{array}{l}\text { Depth } \\
(\mathrm{ft})^{\mathrm{a}}\end{array}$ & $\begin{array}{l}\text { Collection } \\
\text { Date }\end{array}$ & $\begin{array}{c}\text { Field } \\
\text { Preparation }\end{array}$ & $\begin{array}{c}\text { Number } \\
\text { of } \\
\text { Analyses }\end{array}$ & $\begin{array}{c}\text { Number } \\
\text { of } \\
\text { Detects }\end{array}$ & $\begin{array}{c}\text { Detected } \\
\text { Value } \\
\text { ( } \mu \mathrm{g} / \mathrm{L})\end{array}$ & $\begin{array}{c}\text { Non- } \\
\text { detected } \\
\text { Value } \\
(\mu \mathrm{g} / \mathrm{L})\end{array}$ & $\begin{array}{l}\text { Drinking } \\
\text { Water } \\
M^{\prime} L^{b} \\
(\mu \mathrm{g} / \mathrm{L})\end{array}$ & $\begin{array}{l}\text { Frequency } \\
\text { of Detects } \\
>\text { Drinking } \\
\text { Water MCL }\end{array}$ & $\begin{array}{c}\text { NMED }^{c} \\
\text { Groundwater } \\
\text { Standard }^{d} \\
(\mu \mathrm{g} / \mathrm{L})\end{array}$ & $\begin{array}{l}\text { Frequency of } \\
\text { Detects }>\text { NMED } \\
\text { Groundwater } \\
\text { Standard }\end{array}$ \\
\hline Cadmium & 1 & 378 & 08/08/01 & NF & 1 & 1 & 0.188 & - & - & - & - & - \\
\hline Calcium & 1 & 378 & 08/08/01 & $\mathrm{F}$ & 1 & 1 & 10000 & - & - & - & - & - \\
\hline Calcium & 1 & 378 & 08/08/01 & NF & 1 & 1 & 10000 & - & - & - & - & - \\
\hline Chloride & 1 & 378 & $08 / 08 / 01$ & $\mathrm{~F}$ & 1 & 1 & 2000 & - & 250000 & $0 / 1$ & 250000 & $0 / 1$ \\
\hline Chromium & 1 & 378 & 08/08/01 & $\mathrm{F}$ & 1 & 1 & 1.2 & - & 100 & $0 / 1$ & 50 & $0 / 1$ \\
\hline Chromium & 1 & 378 & 08/08/01 & NF & 1 & 1 & 1.3 & - & - & - & - & - \\
\hline Cobalt & 1 & 378 & 08/08/01 & $\mathrm{F}$ & 1 & 0 & - & [0.29] & - & - & 50 & $0 / 1$ \\
\hline Cobalt & 1 & 378 & 08/08/01 & NF & 1 & 0 & - & [0.29] & - & - & - & - \\
\hline Copper & 1 & 378 & 08/08/01 & $\mathrm{F}$ & 1 & 0 & - & {$[0.35]$} & 1300 & $0 / 1$ & 1000 & $0 / 1$ \\
\hline Copper & 1 & 378 & 08/08/01 & NF & 1 & 0 & - & {$[0.35]$} & - & - & - & - \\
\hline Cyanide (total) & 1 & 378 & 08/08/01 & NF & 1 & 0 & - & [10] & - & - & - & - \\
\hline Fluoride & 1 & 378 & 08/08/01 & $\mathrm{F}$ & 1 & 1 & 150 & - & 4000 & $0 / 1$ & 1600 & $0 / 1$ \\
\hline Iron & 1 & 378 & 08/08/01 & $\mathrm{F}$ & 1 & 1 & 11 & - & 300 & $0 / 1$ & 1000 & $0 / 1$ \\
\hline Iron & 1 & 378 & 08/08/01 & NF & 1 & 1 & 35 & - & - & - & - & - \\
\hline Lead & 1 & 378 & 08/08/01 & $\mathrm{F}$ & 1 & 1 & 0.037 & - & 15 & $0 / 2$ & 50 & $0 / 2$ \\
\hline Lead & 1 & 378 & 08/08/01 & NF & 1 & 0 & - & [0.011] & - & - & - & - \\
\hline Magnesium & 1 & 378 & 08/08/01 & $\mathrm{F}$ & 1 & 1 & 1700 & - & - & - & - & - \\
\hline Magnesium & 1 & 378 & 08/08/01 & NF & 1 & 1 & 1700 & - & - & - & - & - \\
\hline Manganese & 1 & 378 & 08/08/01 & $\mathrm{F}$ & 1 & 1 & 110 & - & 50 & $1 / 1$ & 200 & $0 / 1$ \\
\hline Manganese & 1 & 378 & 08/08/01 & NF & 1 & 1 & 120 & - & - & - & - & - \\
\hline Mercury & 1 & 378 & 08/08/01 & $\mathrm{F}$ & 1 & 0 & - & {$[0.012]$} & 2 & $0 / 1$ & - & - \\
\hline Mercury & 1 & 378 & 08/08/01 & NF & 1 & 0 & - & {$[0.012]$} & - & - & 2 & $0 / 1$ \\
\hline Molybdenum & 1 & 378 & 08/08/01 & $\mathrm{F}$ & 1 & 0 & - & [4.1] & - & - & - & - \\
\hline Molybdenum & 1 & 378 & 08/08/01 & NF & 1 & 0 & - & [4.1] & - & - & - & - \\
\hline Nickel & 1 & 378 & 08/08/01 & $\mathrm{F}$ & 1 & 1 & 2.5 & - & 100 & $0 / 1$ & 200 & $0 / 1$ \\
\hline Nickel & 1 & 378 & 08/08/01 & NF & 1 & 1 & 2.3 & - & - & - & - & - \\
\hline Nitrate + Nitrite (as N) & 1 & 378 & 08/08/01 & $\mathrm{F}$ & 1 & 1 & 220 & - & 10000 & $0 / 1$ & - & - \\
\hline
\end{tabular}


Table A-7 (continued)

\begin{tabular}{|c|c|c|c|c|c|c|c|c|c|c|c|c|}
\hline $\begin{array}{l}\text { Parameter } \\
\text { and } \\
\text { Analyte }\end{array}$ & Screen & $\begin{array}{l}\text { Depth } \\
(\mathrm{ft})^{a}\end{array}$ & $\begin{array}{c}\text { Collection } \\
\text { Date }\end{array}$ & $\begin{array}{c}\text { Field } \\
\text { Preparation }\end{array}$ & $\begin{array}{c}\text { Number } \\
\text { of } \\
\text { Analyses }\end{array}$ & $\begin{array}{l}\text { Number } \\
\text { of } \\
\text { Detects }\end{array}$ & $\begin{array}{c}\text { Detected } \\
\text { Value } \\
\text { ( } \mu \mathrm{g} / \mathrm{L})\end{array}$ & $\begin{array}{l}\text { Non- } \\
\text { detected } \\
\text { Value } \\
(\mu \mathrm{g} / \mathrm{L})\end{array}$ & $\begin{array}{l}\text { Drinking } \\
\text { Water } \\
\text { MCL }^{\mathrm{b}} \\
(\mu \mathrm{g} / \mathrm{L})\end{array}$ & $\begin{array}{l}\text { Frequency } \\
\text { of Detects } \\
>\text { Drinking } \\
\text { Water MCL }\end{array}$ & $\begin{array}{c}\text { NMED }^{c} \\
\text { Groundwater } \\
\text { Standard }^{\mathrm{d}} \\
(\mu \mathrm{g} / \mathrm{L})\end{array}$ & $\begin{array}{l}\text { Frequency of } \\
\text { Detects }>\text { NMED } \\
\text { Groundwater } \\
\text { Standard }\end{array}$ \\
\hline Perchlorate & 1 & 378 & 08/08/01 & $\mathrm{F}$ & 1 & 1 & - & [4] & - & - & - & - \\
\hline Phosphorus (total) & 1 & 378 & 08/08/01 & $\mathrm{F}$ & 1 & 0 & - & [50] & - & - & - & - \\
\hline Potassium & 1 & 378 & 08/08/01 & $\mathrm{F}$ & 1 & 1 & 3000 & - & - & - & - & - \\
\hline Potassium & 1 & 378 & 08/08/01 & NF & 1 & 1 & 3100 & - & - & - & - & - \\
\hline Selenium & 1 & 378 & 08/08/01 & $\mathrm{F}$ & 1 & 0 & - & [2.1] & 50 & $0 / 1$ & 50 & $0 / 1$ \\
\hline Selenium & 1 & 378 & 08/08/01 & NF & 1 & 0 & - & [2.1] & - & - & - & - \\
\hline Silica & 1 & 378 & 08/08/01 & $\mathrm{F}$ & 1 & 1 & 64200 & - & - & - & - & - \\
\hline Silica & 1 & 378 & 08/08/01 & NF & 1 & 1 & 64200 & - & - & - & - & - \\
\hline Silver & 1 & 378 & 08/08/01 & $\mathrm{F}$ & 1 & 0 & - & {$[0.41]$} & 100 & $0 / 1$ & 50 & $0 / 1$ \\
\hline Silver & 1 & 378 & 08/08/01 & NF & 1 & 0 & - & [0.41] & - & - & - & - \\
\hline Sodium & 1 & 378 & 08/08/01 & $\mathrm{F}$ & 1 & 1 & 5700 & - & - & - & - & - \\
\hline Sodium & 1 & 378 & 08/08/01 & NF & 1 & 1 & 5800 & - & - & - & - & - \\
\hline Strontium & 1 & 378 & 08/08/01 & $\mathrm{F}$ & 1 & 1 & 52 & - & - & - & - & - \\
\hline Strontium & 1 & 378 & 08/08/01 & NF & 1 & 1 & 53 & - & - & - & - & - \\
\hline Sulfate & 1 & 378 & 08/08/01 & $\mathrm{F}$ & 1 & 1 & 2500 & - & 250000 & $0 / 1$ & 600000 & $0 / 1$ \\
\hline Thallium & 1 & 378 & 08/08/01 & $\mathrm{F}$ & 1 & 1 & 0.731 & - & 2 & $0 / 2$ & - & - \\
\hline Thallium & 1 & 378 & 08/08/01 & NF & 1 & 1 & 0.148 & - & - & - & - & - \\
\hline $\begin{array}{l}\text { Total Kjeldahl } \\
\text { Nitrogen }\end{array}$ & 1 & 378 & 08/08/01 & $\mathrm{F}$ & 1 & 1 & 310 & - & - & - & - & - \\
\hline $\begin{array}{l}\text { Total Kjeldahl } \\
\text { Nitrogen }\end{array}$ & 1 & 378 & 08/08/01 & NF & 1 & 1 & 300 & - & - & - & - & - \\
\hline Uranium & 1 & 378 & 08/08/01 & $\mathrm{F}$ & 1 & 1 & 0.252 & - & 20 & $0 / 1$ & 5000 & $0 / 1$ \\
\hline Uranium & 1 & 378 & 08/08/01 & NF & 1 & 1 & 0.119 & - & - & - & - & - \\
\hline Vanadium & 1 & 378 & 08/08/01 & $\mathrm{F}$ & 1 & 0 & - & {$[0.41]$} & - & - & - & - \\
\hline Vanadium & 1 & 378 & 08/08/01 & NF & 1 & 0 & - & {$[0.41]$} & - & - & - & - \\
\hline Zinc & 1 & 378 & 08/08/01 & $\mathrm{F}$ & 1 & 1 & 43 & - & 5000 & $0 / 1$ & 10000 & $0 / 1$ \\
\hline Zinc & 1 & 378 & 08/08/01 & NF & 1 & 1 & 39 & - & - & - & - & - \\
\hline
\end{tabular}


Table A-7 (continued)

\begin{tabular}{|c|c|c|c|c|c|c|c|c|c|c|c|c|}
\hline $\begin{array}{l}\text { Parameter } \\
\text { and } \\
\text { Analyte }\end{array}$ & Screen & $\begin{array}{c}\text { Depth } \\
(\mathrm{ft})^{\mathrm{a}}\end{array}$ & $\begin{array}{c}\text { Collection } \\
\text { Date }\end{array}$ & $\begin{array}{c}\text { Field } \\
\text { Preparation }\end{array}$ & $\begin{array}{c}\text { Number } \\
\text { of } \\
\text { Analyses }\end{array}$ & $\begin{array}{c}\text { Number } \\
\text { of } \\
\text { Detects }\end{array}$ & $\begin{array}{c}\text { Detected } \\
\text { Value } \\
(\mu \mathrm{g} / \mathrm{L})\end{array}$ & $\begin{array}{c}\text { Non- } \\
\text { detected } \\
\text { Value } \\
(\mu \mathrm{g} / \mathrm{L})\end{array}$ & $\begin{array}{l}\text { Drinking } \\
\text { Water } \\
M^{\prime} L^{b} \\
(\mu \mathrm{g} / \mathrm{L})\end{array}$ & $\begin{array}{l}\text { Frequency } \\
\text { of Detects } \\
>\text { Drinking } \\
\text { Water MCL }\end{array}$ & $\begin{array}{c}\text { NMED }^{\mathrm{C}} \\
\text { Groundwater } \\
\text { Standard }^{\mathrm{d}} \\
(\mu \mathrm{g} / \mathrm{L})\end{array}$ & $\begin{array}{c}\text { Frequency of } \\
\text { Detects }>\text { NMED } \\
\text { Groundwater } \\
\text { Standard }\end{array}$ \\
\hline \multicolumn{13}{|c|}{ Stable Isotope (\%o) } \\
\hline$\delta \mathrm{D}$ & 1 & 378 & 08/08/01 & $\mathrm{NF}$ & 1 & 1 & -80 & - & - & - & - & - \\
\hline$\delta^{15} \mathrm{~N}\left(\mathrm{NO}_{3}\right)$ & 1 & 378 & $08 / 08 / 01$ & $\mathrm{NF}$ & 1 & 1 & +1.7 & - & - & - & - & - \\
\hline$\delta^{18} \mathrm{O}$ & 1 & 378 & $08 / 08 / 01$ & $\mathrm{NF}$ & 1 & 1 & -11.5 & - & - & - & - & - \\
\hline
\end{tabular}

a The static water level for the regional aquifer at R-7 was $902.8 \mathrm{ft}$ when the well was drilled.

${ }^{\mathrm{b}} \mathrm{MCL}=$ Maximum contaminant level. US Environmental Protection Agency (EPA) MCLs are from the National Primary Water Regulations, 40 CFR Part 141. US EPA secondary MCLs are from National Secondary Drinking Water Regulations, 20 NMAC 7.1.

${ }^{\mathrm{C}} \mathrm{NMED}=$ New Mexico Environment Department.

d State of New Mexico groundwater standards are from New Mexico Quality Control Commission Regulations, Ground and Surface Water Protection, 20 NMAC 6.2.

$\mathrm{NF}=$ Nonfiltered

f $=$ Not available or applicable.

${ }^{\mathrm{g}} \mathrm{NTU}=$ Nephelometric turbidity unit.

${ }^{\mathrm{h}} \mathrm{F}=$ Filtered 
Table A-8

Regional Well R-7 Screen 3 Second Round Sample Results: Data Summary for Inorganic Chemicals

\begin{tabular}{|c|c|c|c|c|c|c|c|c|c|c|c|c|}
\hline $\begin{array}{l}\text { Parameter } \\
\text { and } \\
\text { Analyte }\end{array}$ & Screen & $\begin{array}{l}\text { Depth } \\
(\mathrm{ft})^{a}\end{array}$ & $\begin{array}{l}\text { Collection } \\
\text { Date }\end{array}$ & $\begin{array}{c}\text { Field } \\
\text { Preparation }\end{array}$ & $\begin{array}{c}\text { Number } \\
\text { of } \\
\text { Analyses }\end{array}$ & $\begin{array}{c}\text { Number } \\
\text { of } \\
\text { Detects }\end{array}$ & $\begin{array}{c}\text { Detected } \\
\text { Value } \\
\text { ( } \mu \mathrm{g} / \mathrm{L})\end{array}$ & $\begin{array}{c}\text { Non- } \\
\text { detected } \\
\text { Value } \\
(\mu \mathrm{g} / \mathrm{L})\end{array}$ & $\begin{array}{l}\text { Drinking } \\
\text { Water } \\
M^{\prime} L^{b} \\
(\mu g / L)\end{array}$ & $\begin{array}{l}\text { Frequency } \\
\text { of Detects } \\
>\text { Drinking } \\
\text { Water MCL }\end{array}$ & $\begin{array}{c}\text { NMED }^{c} \\
\text { Groundwater } \\
\text { Standard }^{\mathrm{d}} \\
(\mu \mathrm{g} / \mathrm{L})\end{array}$ & $\begin{array}{l}\text { Frequency of } \\
\text { Detects }>\text { NMED } \\
\text { Groundwater } \\
\text { Standard }\end{array}$ \\
\hline \multicolumn{13}{|l|}{ Field Parameter } \\
\hline $\begin{array}{l}\text { Field Alkalinity (total } \\
\text { as } \mathrm{CaCO}_{3} \text { ) }\end{array}$ & 3 & 915 & 08/09/01 & $\mathrm{NF}^{\mathrm{e}}$ & 1 & 1 & 97500 & $-^{f}$ & - & - & - & - \\
\hline Dissolved Oxygen & 3 & 915 & 08/09/01 & NF & 1 & 1 & - & - & - & - & - & - \\
\hline $\mathrm{pH}$ & 3 & 915 & 08/09/01 & NF & 1 & 1 & 6.81 & - & $>6 \&<9$ & $0 / 1$ & $>6 \&<9$ & $0 / 1$ \\
\hline $\begin{array}{l}\text { Specific Conductance } \\
(\mu \mathrm{S} / \mathrm{cm})\end{array}$ & 3 & 915 & 08/09/01 & NF & 1 & 1 & 270.8 & - & - & $0 / 1$ & - & $0 / 1$ \\
\hline Temperature $\left({ }^{\circ} \mathrm{C}\right)$ & 3 & 915 & 08/09/01 & NF & 1 & 1 & 17.4 & - & - & $0 / 1$ & - & $0 / 1$ \\
\hline Turbidity (NTU9) & 3 & 915 & 08/09/01 & NF & 1 & 1 & 0.9 & - & - & $0 / 1$ & - & $0 / 1$ \\
\hline \multicolumn{13}{|l|}{ Analyte } \\
\hline $\begin{array}{l}\text { Lab Alkalinity (total as } \\
\mathrm{CaCO}_{3} \text { ) }\end{array}$ & 3 & 915 & 08/09/01 & $\mathrm{F}^{\mathrm{h}}$ & 1 & 1 & 110000 & - & - & - & - & - \\
\hline Aluminum & 3 & 915 & 08/09/01 & $\mathrm{F}$ & 1 & 1 & 53 & - & 50 & $1 / 1$ & 5000 & $0 / 1$ \\
\hline Aluminum & 3 & 915 & $08 / 09 / 01$ & $\mathrm{NF}$ & 1 & 1 & 86 & - & - & - & - & - \\
\hline Ammonia (as N) & 3 & 915 & $08 / 09 / 01$ & $\mathrm{~F}$ & 1 & 1 & 460 & - & - & - & - & - \\
\hline Antimony & 3 & 915 & 08/09/01 & $\mathrm{F}$ & 1 & 0 & - & {$[0.169]$} & 6 & $0 / 2$ & - & - \\
\hline Antimony & 3 & 915 & 08/09/01 & NF & 1 & 0 & - & [0.043] & - & - & - & - \\
\hline Arsenic & 3 & 915 & 08/09/01 & $\mathrm{F}$ & 1 & 0 & - & [2] & 50 & $0 / 1$ & 100 & $0 / 1$ \\
\hline Arsenic & 3 & 915 & 08/09/01 & NF & 1 & 1 & 2.5 & - & - & - & - & - \\
\hline Barium & 3 & 915 & 08/09/01 & $\mathrm{F}$ & 1 & 1 & 240 & - & 2000 & $0 / 1$ & 1000 & $0 / 1$ \\
\hline Barium & 3 & 915 & 08/09/01 & NF & 1 & 1 & 260 & - & - & - & - & - \\
\hline Beryllium & 3 & 915 & 08/09/01 & $\mathrm{F}$ & 1 & 1 & 0.022 & - & 4 & $0 / 2$ & - & - \\
\hline Beryllium & 3 & 915 & $08 / 09 / 01$ & $\mathrm{NF}$ & 1 & 1 & 0.244 & - & - & - & - & - \\
\hline Boron & 3 & 915 & 08/09/01 & $\mathrm{F}$ & 1 & 0 & - & [24] & - & - & 750 & $0 / 1$ \\
\hline Boron & 3 & 915 & 08/09/01 & $\mathrm{NF}$ & 1 & 0 & - & [28] & - & - & - & - \\
\hline Bromide & 3 & 915 & 08/09/01 & $\mathrm{F}$ & 1 & 0 & - & [200] & - & - & - & - \\
\hline Cadmium & 3 & 915 & 08/09/01 & $F$ & 1 & 1 & 0.143 & - & 5 & $0 / 2$ & 10 & $0 / 2$ \\
\hline
\end{tabular}


Table A-8 (continued)

\begin{tabular}{|c|c|c|c|c|c|c|c|c|c|c|c|c|}
\hline $\begin{array}{l}\text { Parameter } \\
\text { and } \\
\text { Analyte }\end{array}$ & Screen & $\begin{array}{l}\text { Depth } \\
(\mathrm{ft})^{\mathrm{a}}\end{array}$ & $\begin{array}{l}\text { Collection } \\
\text { Date }\end{array}$ & $\begin{array}{c}\text { Field } \\
\text { Preparation }\end{array}$ & $\begin{array}{c}\text { Number } \\
\text { of } \\
\text { Analyses }\end{array}$ & $\begin{array}{c}\text { Number } \\
\text { of } \\
\text { Detects }\end{array}$ & $\begin{array}{c}\text { Detected } \\
\text { Value } \\
\text { ( } \mu \mathrm{g} / \mathrm{L})\end{array}$ & $\begin{array}{l}\text { Non- } \\
\text { detected } \\
\text { Value } \\
(\mu \mathrm{g} / \mathrm{L})\end{array}$ & $\begin{array}{l}\text { Drinking } \\
\text { Water } \\
M^{\prime} L^{b} \\
(\mu g / L)\end{array}$ & $\begin{array}{l}\text { Frequency } \\
\text { of Detects } \\
>\text { Drinking } \\
\text { Water MCL }\end{array}$ & $\begin{array}{c}\text { NMED }^{c} \\
\text { Groundwater } \\
\text { Standard } \\
(\mu \mathrm{g} / \mathrm{L})\end{array}$ & $\begin{array}{c}\text { Frequency of } \\
\text { Detects }>\text { NMED } \\
\text { Groundwater } \\
\text { Standard }\end{array}$ \\
\hline Cadmium & 3 & 915 & 08/09/01 & NF & 1 & 1 & 0.301 & - & - & - & - & - \\
\hline Calcium & 3 & 915 & 08/09/01 & $\mathrm{F}$ & 1 & 1 & 22000 & - & - & - & - & - \\
\hline Calcium & 3 & 915 & 08/09/01 & NF & 1 & 1 & 22000 & - & - & - & - & - \\
\hline Chloride & 3 & 915 & 08/09/01 & $\mathrm{F}$ & 1 & 1 & 2500 & - & 250000 & $0 / 1$ & 250000 & $0 / 1$ \\
\hline Chromium & 3 & 915 & 08/09/01 & $\mathrm{F}$ & 1 & 1 & 1.1 & - & 100 & $0 / 1$ & 50 & $0 / 1$ \\
\hline Chromium & 3 & 915 & 08/09/01 & NF & 1 & 1 & 6.4 & - & - & - & - & - \\
\hline Cobalt & 3 & 915 & 08/09/01 & $\mathrm{F}$ & 1 & 1 & 11 & - & - & - & 50 & $0 / 1$ \\
\hline Cobalt & 3 & 915 & 08/09/01 & NF & 1 & 1 & 11 & - & - & - & - & - \\
\hline Copper & 3 & 915 & 08/09/01 & $\mathrm{F}$ & 1 & 0 & - & {$[0.35]$} & 1300 & $0 / 1$ & 1000 & $0 / 1$ \\
\hline Copper & 3 & 915 & 08/09/01 & NF & 1 & 0 & - & [0.35] & - & - & - & - \\
\hline Cyanide (total) & 3 & 915 & 08/09/01 & NF & 1 & 0 & - & [10] & - & - & - & - \\
\hline Fluoride & 3 & 915 & 08/09/01 & $\mathrm{F}$ & 1 & 1 & 400 & - & 4000 & $0 / 1$ & 1600 & $0 / 1$ \\
\hline Iron & 3 & 915 & 08/09/01 & $\mathrm{F}$ & 1 & 1 & 14000 & - & 300 & $1 / 1$ & 1000 & $1 / 1$ \\
\hline Iron & 3 & 915 & 08/09/01 & NF & 1 & 0 & - & [21000] & - & - & - & - \\
\hline Lead & 3 & 915 & 08/09/01 & $\mathrm{F}$ & 1 & 0 & - & [0.011] & 15 & $0 / 2$ & 50 & $0 / 2$ \\
\hline Lead & 3 & 915 & 08/09/01 & NF & 1 & 1 & 0.338 & - & - & - & - & - \\
\hline Magnesium & 3 & 915 & 08/09/01 & $\mathrm{F}$ & 1 & 1 & 5300 & - & - & - & - & - \\
\hline Magnesium & 3 & 915 & 08/09/01 & NF & 1 & 1 & 5400 & - & - & - & - & - \\
\hline Manganese & 3 & 915 & 08/09/01 & $\mathrm{F}$ & 1 & 1 & 3400 & - & 50 & $1 / 1$ & 200 & $1 / 1$ \\
\hline Manganese & 3 & 915 & 08/09/01 & NF & 1 & 1 & 3500 & - & - & - & - & - \\
\hline Mercury & 3 & 915 & 08/09/01 & $\mathrm{F}$ & 1 & 0 & - & {$[0.012]$} & 2 & $0 / 2$ & - & - \\
\hline Mercury & 3 & 915 & 08/09/01 & NF & 1 & 0 & - & {$[0.012]$} & - & - & 2 & $0 / 1$ \\
\hline Molybdenum & 3 & 915 & 08/09/01 & $\mathrm{F}$ & 1 & 1 & 19 & - & - & - & - & - \\
\hline Molybdenum & 3 & 915 & 08/09/01 & NF & 1 & 1 & 22 & - & - & - & - & - \\
\hline Nickel & 3 & 915 & 08/09/01 & $\mathrm{F}$ & 1 & 1 & 120 & - & 100 & $1 / 1$ & 200 & $0 / 1$ \\
\hline Nickel & 3 & 915 & 08/09/01 & NF & 1 & 1 & 130 & - & - & - & - & - \\
\hline Nitrate + Nitrite (as N) & 3 & 915 & 08/09/01 & $\mathrm{F}$ & 1 & 0 & - & [50] & 10000 & $0 / 1$ & - & - \\
\hline
\end{tabular}


Table A-8 (continued)

\begin{tabular}{|c|c|c|c|c|c|c|c|c|c|c|c|c|}
\hline $\begin{array}{l}\text { Parameter } \\
\text { and } \\
\text { Analyte }\end{array}$ & Screen & $\begin{array}{l}\text { Depth } \\
(\mathrm{ft})^{\mathrm{a}}\end{array}$ & $\begin{array}{c}\text { Collection } \\
\text { Date }\end{array}$ & $\begin{array}{c}\text { Field } \\
\text { Preparation }\end{array}$ & $\begin{array}{c}\text { Number } \\
\text { of } \\
\text { Analyses }\end{array}$ & $\begin{array}{c}\text { Number } \\
\text { of } \\
\text { Detects }\end{array}$ & $\begin{array}{c}\text { Detected } \\
\text { Value } \\
\text { ( } \mu \mathrm{g} / \mathrm{L})\end{array}$ & $\begin{array}{l}\text { Non- } \\
\text { detected } \\
\text { Value } \\
(\mu \mathrm{g} / \mathrm{L})\end{array}$ & $\begin{array}{l}\text { Drinking } \\
\text { Water } \\
M C L^{b} \\
(\mu \mathrm{g} / \mathrm{L})\end{array}$ & $\begin{array}{l}\text { Frequency } \\
\text { of Detects } \\
>\text { Drinking } \\
\text { Water MCL }\end{array}$ & $\begin{array}{c}\text { NMED }^{c} \\
\text { Groundwater } \\
\text { Standard }^{d} \\
(\mu \mathrm{g} / \mathrm{L})\end{array}$ & $\begin{array}{c}\text { Frequency of } \\
\text { Detects }>\text { NMED } \\
\text { Groundwater } \\
\text { Standard }\end{array}$ \\
\hline Perchlorate & 3 & 915 & 08/09/01 & $\mathrm{F}$ & 1 & 0 & - & [4] & - & - & - & - \\
\hline Phosphorus (total) & 3 & 915 & $08 / 09 / 01$ & $\mathrm{~F}$ & 1 & 0 & - & [50] & - & - & - & - \\
\hline Potassium & 3 & 915 & $08 / 09 / 01$ & $\mathrm{~F}$ & 1 & 1 & 3000 & - & - & - & - & - \\
\hline Potassium & 3 & 915 & 08/09/01 & NF & 1 & 1 & 3100 & - & - & - & - & - \\
\hline Selenium & 3 & 915 & $08 / 09 / 01$ & $\mathrm{~F}$ & 1 & 0 & - & [2.1] & 50 & $0 / 1$ & 50 & $0 / 1$ \\
\hline Selenium & 3 & 915 & $08 / 09 / 01$ & NF & 1 & 0 & - & [2.1] & - & - & - & - \\
\hline Silica & 3 & 915 & 08/09/01 & $\mathrm{F}$ & 1 & 1 & 44940 & - & - & - & - & - \\
\hline Silica & 3 & 915 & 08/09/01 & NF & 1 & 1 & 47080 & - & - & - & - & - \\
\hline Silver & 3 & 915 & 08/09/01 & $\mathrm{F}$ & 1 & 0 & - & {$[0.41]$} & 100 & $0 / 1$ & 50 & $0 / 1$ \\
\hline Silver & 3 & 915 & 08/09/01 & NF & 1 & 0 & - & {$[0.41]$} & - & - & - & - \\
\hline Sodium & 3 & 915 & 08/09/01 & $\mathrm{F}$ & 1 & 1 & 10000 & - & - & - & - & - \\
\hline Sodium & 3 & 915 & 08/09/01 & NF & 1 & 1 & 10000 & - & - & - & - & - \\
\hline Strontium & 3 & 915 & 08/09/01 & $\mathrm{F}$ & 1 & 1 & 140 & - & - & - & - & - \\
\hline Strontium & 3 & 915 & 08/09/01 & NF & 1 & 1 & 140 & - & - & - & - & - \\
\hline Sulfate & 3 & 915 & 08/09/01 & $\mathrm{F}$ & 1 & 0 & - & [1000] & 250000 & $0 / 1$ & 600000 & $0 / 1$ \\
\hline Thallium & 3 & 915 & 08/09/01 & $\mathrm{F}$ & 1 & 1 & 0.204 & - & 2 & $0 / 2$ & - & - \\
\hline Thallium & 3 & 915 & 08/09/01 & NF & 1 & 1 & 0.847 & - & - & - & - & - \\
\hline $\begin{array}{l}\text { Total Kjeldahl } \\
\text { Nitrogen }\end{array}$ & 3 & 915 & 08/09/01 & $\mathrm{F}$ & 1 & 1 & 1300 & - & - & - & - & - \\
\hline $\begin{array}{l}\text { Total Kjeldahl } \\
\text { Nitrogen }\end{array}$ & 3 & 915 & 08/09/01 & NF & 1 & 1 & 1500 & - & - & - & - & - \\
\hline Uranium & 3 & 915 & 08/09/01 & $\mathrm{F}$ & 1 & 1 & 0.051 & - & 20 & $0 / 1$ & 5000 & $0 / 1$ \\
\hline Uranium & 3 & 915 & 08/09/01 & NF & 1 & 1 & 0.304 & - & - & - & - & - \\
\hline Vanadium & 3 & 915 & 08/09/01 & $\mathrm{F}$ & 1 & 0 & - & {$[0.41]$} & - & - & - & - \\
\hline Vanadium & 3 & 915 & 08/09/01 & $\mathrm{NF}$ & 1 & 1 & 0.5 & - & - & - & - & - \\
\hline Zinc & 3 & 915 & 08/09/01 & $\mathrm{F}$ & 1 & 1 & 140 & - & 5000 & $0 / 1$ & 10000 & $0 / 1$ \\
\hline Zinc & 3 & 915 & 08/09/01 & NF & 1 & 1 & 190 & - & - & - & - & - \\
\hline
\end{tabular}


Table A-8 (continued)

\begin{tabular}{|c|c|c|c|c|c|c|c|c|c|c|c|c|}
\hline $\begin{array}{c}\text { Parameter } \\
\text { and } \\
\text { Analyte }\end{array}$ & Screen & $\begin{array}{c}\text { Depth } \\
(\mathrm{ft})^{\mathrm{a}}\end{array}$ & $\begin{array}{l}\text { Collection } \\
\text { Date }\end{array}$ & $\begin{array}{c}\text { Field } \\
\text { Preparation }\end{array}$ & $\begin{array}{l}\text { Number } \\
\text { of } \\
\text { Analyses }\end{array}$ & $\begin{array}{c}\text { Number } \\
\text { of } \\
\text { Detects }\end{array}$ & $\begin{array}{c}\text { Detected } \\
\text { Value } \\
\text { ( } \mu \mathrm{g} / \mathrm{L})\end{array}$ & $\begin{array}{c}\text { Non- } \\
\text { detected } \\
\text { Value } \\
(\mu \mathrm{g} / \mathrm{L})\end{array}$ & $\begin{array}{l}\text { Drinking } \\
\text { Water } \\
M^{\prime} L^{b} \\
(\mu \mathrm{g} / \mathrm{L})\end{array}$ & $\begin{array}{l}\text { Frequency } \\
\text { of Detects } \\
>\text { Drinking } \\
\text { Water MCL }\end{array}$ & $\begin{array}{c}\text { NMED }^{c} \\
\text { Groundwater } \\
\text { Standard }^{\mathrm{d}} \\
(\mu \mathrm{g} / \mathrm{L})\end{array}$ & $\begin{array}{c}\text { Frequency of } \\
\text { Detects }>\text { NMED } \\
\text { Groundwater } \\
\text { Standard }\end{array}$ \\
\hline \multicolumn{13}{|c|}{ Stable Isotope (\%o) } \\
\hline$\delta \mathrm{D}$ & 3 & 915 & 08/09/01 & $\mathrm{NF}$ & 1 & 1 & -78 & - & - & - & - & - \\
\hline$\delta^{15} \mathrm{O}\left(\mathrm{NO}_{3}\right)$ & 3 & 915 & 08/09/01 & $\mathrm{NF}$ & 1 & 1 & +0.9 & - & - & - & - & - \\
\hline$\delta^{18} \mathrm{O}$ & 3 & 915 & $08 / 09 / 01$ & NF & 1 & 1 & -11.3 & - & - & - & - & - \\
\hline
\end{tabular}

a The static water level for the regional aquifer at R-7 was $902.8 \mathrm{ft}$ when the well was drilled.

${ }^{\mathrm{b}} \mathrm{MCL}=$ Maximum contaminant level. US Environmental Protection Agency (EPA) MCLs are from the National Primary Water Regulations, 40 CFR Part 141. US EPA secondary MCLs are from National Secondary Drinking Water Regulations, 20 NMAC 7.1.

${ }^{c}$ NMED $=$ New Mexico Environment Department.

${ }^{d}$ State of New Mexico groundwater standards are from New Mexico Quality Control Commission Regulations, Ground and Surface Water Protection, 20 NMAC 6.2.

$\mathrm{NF}=$ Nonfiltered

f $-=$ Not available or applicable.

${ }^{g}$ NTU $=$ Nephelometric turbidity unit.

${ }^{h} \mathrm{~F}=$ Filtered. 
Table A-9

Regional Well R-7 Screen 1 Second Round Sample Results: Data Summary for Detected Organic Chemicals

\begin{tabular}{|c|c|c|c|c|c|c|c|c|c|c|c|c|}
\hline $\begin{array}{l}\text { Parameter } \\
\text { and } \\
\text { Analyte }\end{array}$ & Screen & $\begin{array}{c}\text { Depth } \\
\text { (ft) }\end{array}$ & $\begin{array}{l}\text { Collection } \\
\text { Date }\end{array}$ & $\begin{array}{c}\text { Field } \\
\text { Preparation }\end{array}$ & $\begin{array}{c}\text { Number } \\
\text { of } \\
\text { Analyses }\end{array}$ & $\begin{array}{c}\text { Number } \\
\text { of } \\
\text { Detects }\end{array}$ & $\begin{array}{c}\text { Detected } \\
\text { Value } \\
(\mu \mathrm{g} / \mathrm{L})\end{array}$ & $\begin{array}{c}\text { Non- } \\
\text { detected } \\
\text { Value } \\
(\mu \mathrm{g} / \mathrm{L})\end{array}$ & $\begin{array}{l}\text { Drinking } \\
\text { Water } \\
M C^{b} \\
(\mu g / L)\end{array}$ & $\begin{array}{l}\text { Frequency } \\
\text { of Detects } \\
>\text { Drinking } \\
\text { Water MCL }\end{array}$ & $\begin{array}{c}\text { NMED }^{c} \\
\text { Groundwater } \\
\text { Standard }^{d} \\
(\mu \mathrm{g} / \mathrm{L})\end{array}$ & $\begin{array}{c}\text { Frequency of } \\
\text { Detects > NMED } \\
\text { Groundwater } \\
\text { Standard }\end{array}$ \\
\hline Acetone & 1 & 378 & 08/08/01 & $\mathrm{NF}^{\mathrm{e}}$ & 1 & 1 & 8 & $-^{f}$ & - & - & - & - \\
\hline
\end{tabular}

${ }^{a}$ The static water level for the regional aquifer at R-7 was $902.8 \mathrm{ft}$ when the well was drilled.

${ }^{\mathrm{b}} \mathrm{MCL}=$ Maximum contaminant level. US Environmental Protection Agency (EPA) MCLs are from the National Primary Water Regulations, 40 CFR Part 141. US EPA secondary MCLs are from National Secondary Drinking Water Regulations, 20 NMAC 7.1.

${ }_{\text {NMED }}=$ New Mexico Environment Department.

d State of New Mexico groundwater standards are from New Mexico Quality Control Commission Regulations, Ground and Surface Water Protection, 20 NMAC 6.2.

${ }_{\mathrm{N}}^{\mathrm{NF}}=$ Nonfiltered.

${ }^{f}-=$ Not available or applicable

Table A-10

Regional Well R-7 Screen 3 Second Round Sample Results: Data Summary for Detected Organic Chemicals

\begin{tabular}{|c|c|c|c|c|c|c|c|c|c|c|c|c|}
\hline $\begin{array}{l}\text { Parameter } \\
\text { and } \\
\text { Analyte }\end{array}$ & Screen & $\begin{array}{c}\text { Depth } \\
(\mathrm{ft})^{\mathrm{a}}\end{array}$ & $\begin{array}{l}\text { Collection } \\
\text { Date }\end{array}$ & $\begin{array}{c}\text { Field } \\
\text { Preparation }\end{array}$ & $\begin{array}{l}\text { Number } \\
\text { of } \\
\text { Analyses }\end{array}$ & $\begin{array}{c}\text { Number } \\
\text { of } \\
\text { Detects }\end{array}$ & $\begin{array}{l}\text { Detected } \\
\text { Value } \\
\text { ( } \mu \mathrm{g} / \mathrm{L})\end{array}$ & $\begin{array}{l}\text { Non- } \\
\text { detected } \\
\text { Value } \\
(\mu \mathrm{g} / \mathrm{L})\end{array}$ & $\begin{array}{l}\text { Drinking } \\
\text { Water } \\
M^{\prime} L^{b} \\
(\mu \mathrm{g} / \mathrm{L})\end{array}$ & $\begin{array}{l}\text { Frequency } \\
\text { of Detects } \\
>\text { Drinking } \\
\text { Water MCL }\end{array}$ & $\begin{array}{c}\text { NMED }^{c} \\
\text { Groundwater } \\
\text { Standard }^{\mathrm{d}} \\
(\mu \mathrm{g} / \mathrm{L})\end{array}$ & $\begin{array}{c}\text { Frequency of } \\
\text { Detects }>\text { NMED } \\
\text { Groundwater } \\
\text { Standard }\end{array}$ \\
\hline Acetone & 3 & 915 & 08/09/01 & $\mathrm{NF}^{\mathrm{e}}$ & 1 & 1 & 44 & $-^{f}$ & - & - & - & - \\
\hline Methylphenol[4-] & 3 & 915 & 08/09/01 & NF & 1 & 1 & 1.8 & - & - & - & - & - \\
\hline Total Organic Carbon & 3 & 915 & 08/09/01 & NF & 1 & 1 & 9200 & - & - & - & - & - \\
\hline
\end{tabular}

The static water level for the regional aquifer at R-7 was $902.8 \mathrm{ft}$ when the well was drilled

${ }^{\mathrm{b}} \mathrm{MCL}=$ Maximum contaminant level. US Environmental Protection Agency (EPA) MCLs are from the National Primary Water Regulations, 40 CFR Part 141. US EPA secondary MCLs are from National Secondary Drinking Water Regulations, 20 NMAC 7.1

${ }^{c}$ NMED = New Mexico Environment Department.

${ }^{\mathrm{d}}$ State of New Mexico groundwater standards are from New Mexico Quality Control Commission Regulations, Ground and Surface Water Protection, 20 NMAC 6.2.

NF = Nonfiltered

${ }^{f}-=$ Not available or applicable. 
Table A-11

Regional Well R-7 Screen 1 Second Round Sample Results: Data Summary for Radionuclides

\begin{tabular}{|c|c|c|c|c|c|c|c|c|c|c|}
\hline $\begin{array}{l}\text { Parameter } \\
\text { and } \\
\text { Analyte }\end{array}$ & Screen & $\begin{array}{c}\text { Depth } \\
(\text { (ft) }\end{array}$ & $\begin{array}{l}\text { Collection } \\
\text { Date }\end{array}$ & $\begin{array}{c}\text { Field } \\
\text { Preparation }\end{array}$ & $\begin{array}{l}\text { Number } \\
\text { of } \\
\text { Analyses }\end{array}$ & $\begin{array}{c}\text { Number } \\
\text { of } \\
\text { Detects }\end{array}$ & $\begin{array}{c}\text { Detected } \\
\text { Value (pCi/L) }\end{array}$ & $\begin{array}{c}\text { Nondetected } \\
\text { Value } \\
\text { (pCi/L) }\end{array}$ & $\begin{array}{l}\text { Drinking } \\
\text { Water } M C L^{b} \\
\text { (pCi/L) }\end{array}$ & $\begin{array}{c}\text { Frequency of } \\
\text { Detects > Drinking } \\
\text { Water MCL }\end{array}$ \\
\hline Americium-241 & 1 & 378 & 08/08/01 & $\mathrm{NF}^{\mathrm{c}}$ & 1 & 0 & $-^{d}$ & {$[-0.003]$} & - & - \\
\hline Cobalt-60 & 1 & 378 & 08/08/01 & $\mathrm{NF}$ & 1 & 0 & - & {$[-6.1]$} & - & - \\
\hline Gross Alpha Radiation & 1 & 378 & 08/08/01 & NF & 1 & 0 & - & {$[0.1]$} & - & - \\
\hline Gross Beta Radiation & 1 & 378 & 08/08/01 & $\mathrm{NF}$ & 1 & 1 & 4.5 & - & - & - \\
\hline Gross Gamma Radiation & 1 & 378 & 08/08/01 & NF & 1 & 1 & 123 & - & - & - \\
\hline Lanthanum-140 & 1 & 378 & 08/08/01 & NF & 1 & 0 & 一 & {$[-10]$} & - & - \\
\hline Plutonium-238 & 1 & 378 & 08/08/01 & NF & 1 & 0 & - & [0] & - & - \\
\hline Plutonium-239 & 1 & 378 & 08/08/01 & NF & 1 & 0 & - & [0.011] & - & - \\
\hline Sodium-22 & 1 & 378 & 08/08/01 & $\mathrm{NF}$ & 1 & 0 & - & [3] & - & - \\
\hline Strontium-90 & 1 & 378 & 08/08/01 & NF & 1 & 0 & - & {$[0.5]$} & - & - \\
\hline Technetium-99 & 1 & 378 & 08/08/01 & $\mathrm{NF}$ & 1 & 0 & - & {$[0.62]$} & - & - \\
\hline Tritium & 1 & 378 & 08/08/01 & $\mathrm{NF}$ & 1 & 1 & 3.38 & - & 20000 & $0 / 1$ \\
\hline Uranium-234 & 1 & 378 & 08/08/01 & $\mathrm{NF}$ & 1 & 0 & - & {$[0.109]$} & - & - \\
\hline Uranium-235 & 1 & 378 & 08/08/01 & $\mathrm{NF}$ & 1 & 0 & - & {$[0.032]$} & - & - \\
\hline Uranium-238 & 1 & 378 & 08/08/01 & $\mathrm{NF}$ & 1 & 0 & - & {$[0.042]$} & - & - \\
\hline
\end{tabular}

${ }^{a}$ The static water level for the regional aquifer at R-7 was $902.8 \mathrm{ft}$ when the well was drilled.

${ }^{b} \mathrm{MCL}=$ Maximum contaminant level. US Environmental Protection Agency (EPA) MCLs are from the National Primary Water Regulations, 40 CFR Part 141. US EPA secondary MCLs are from National Secondary Drinking Water Regulations, 20 NMAC 7.1.

${ }^{\mathrm{C}} \mathrm{NF}=$ Nonfiltered.

d $-=$ Not available or applicable 
Table A-12

Regional Well R-7 Screen 3 Second Round Sample Results: Data Summary for Radionuclides

\begin{tabular}{|c|c|c|c|c|c|c|c|c|c|c|}
\hline $\begin{array}{l}\text { Parameter } \\
\text { and } \\
\text { Analyte }\end{array}$ & Screen & $\begin{array}{l}\text { Depth } \\
(\mathrm{ft})^{\mathrm{a}}\end{array}$ & $\begin{array}{l}\text { Collection } \\
\text { Date }\end{array}$ & $\begin{array}{c}\text { Field } \\
\text { Preparation }\end{array}$ & $\begin{array}{l}\text { Number } \\
\text { of } \\
\text { Analyses }\end{array}$ & $\begin{array}{c}\text { Number } \\
\text { of } \\
\text { Detects }\end{array}$ & $\begin{array}{c}\text { Detected } \\
\text { Value (pCi/L) }\end{array}$ & $\begin{array}{c}\text { Nondetected } \\
\text { Value } \\
\text { (pCi/L) }\end{array}$ & $\begin{array}{c}\text { Drinking } \\
\text { Water MCL } \\
(p C i / L)\end{array}$ & $\begin{array}{c}\text { Frequency of } \\
\text { Detects > Drinking } \\
\text { Water MCL }\end{array}$ \\
\hline Americium-241 & 3 & 915 & 08/09/01 & $\mathrm{NF}^{\mathrm{C}}$ & 1 & 0 & $-^{d}$ & [0.019] & - & - \\
\hline Cobalt-60 & 3 & 915 & 08/09/01 & NF & 1 & 0 & - & [2.6] & - & - \\
\hline Gross Alpha Radiation & 3 & 915 & 08/09/01 & NF & 1 & 1 & 2.9 & - & - & - \\
\hline Gross Beta Radiation & 3 & 915 & 08/09/01 & NF & 1 & 1 & 3.9 & - & - & - \\
\hline Gross Gamma Radiation & 3 & 915 & 08/09/01 & NF & 1 & 1 & 122 & - & - & - \\
\hline Plutonium-238 & 3 & 915 & 08/09/01 & NF & 1 & 0 & - & {$[0.029]$} & 一 & - \\
\hline Plutonium-239 & 3 & 915 & 08/09/01 & NF & 1 & 0 & - & {$[0.004]$} & - & - \\
\hline Potassium-40 & 3 & 915 & 08/09/01 & NF & 1 & 0 & - & [90] & - & - \\
\hline Sodium-22 & 3 & 915 & 08/09/01 & NF & 1 & 0 & - & {$[-1.3]$} & - & - \\
\hline Strontium-90 & 3 & 915 & 08/09/01 & NF & 1 & 0 & - & {$[0.9]$} & - & - \\
\hline Technetium-99 & 3 & 915 & 08/09/01 & NF & 1 & 0 & - & {$[-1.57]$} & - & - \\
\hline Tritium & 3 & 915 & 08/09/01 & NF & 1 & 1 & 1.47 & - & 20000 & $0 / 1$ \\
\hline Uranium-234 & 3 & 915 & 08/09/01 & NF & 1 & 0 & - & {$[0.076]$} & - & - \\
\hline Uranium-235 & 3 & 915 & 08/09/01 & NF & 1 & 0 & - & {$[0.036]$} & - & - \\
\hline Uranium-238 & 3 & 915 & 08/09/01 & NF & 1 & 0 & - & {$[0.062]$} & - & - \\
\hline
\end{tabular}

a The static water level for the regional aquifer at R-7 was $902.8 \mathrm{ft}$ when the well was drilled.

${ }^{\mathrm{b}} \mathrm{MCL}=$ Maximum contaminant level. US Environmental Protection Agency (EPA) MCLs are from the National Primary Water Regulations, 40 CFR Part 141. US EPA secondary MCLs are from National Secondary Drinking Water Regulations, 20 NMAC 7.1.

${ }_{d}^{\mathrm{N}} \mathrm{NF}=$ Nonfiltered.

d $-=$ Not available or applicable 
Table A-13

Well R-7 Screen 1 Third Round Sample Results: Data Summary for Inorganic Chemicals

\begin{tabular}{|c|c|c|c|c|c|c|c|c|c|c|c|c|}
\hline $\begin{array}{l}\text { Parameter } \\
\text { and } \\
\text { Analyte }\end{array}$ & Screen & $\begin{array}{l}\text { Depth } \\
(\mathrm{ft})^{\mathrm{a}}\end{array}$ & $\begin{array}{l}\text { Collection } \\
\text { Date }\end{array}$ & $\begin{array}{c}\text { Field } \\
\text { Preparation }\end{array}$ & $\begin{array}{l}\text { Number } \\
\text { of } \\
\text { Analyses }\end{array}$ & $\begin{array}{l}\text { Number } \\
\text { of } \\
\text { Detects }\end{array}$ & $\begin{array}{l}\text { Detected } \\
\text { Value } \\
\text { ( } \mu \mathrm{g} / \mathrm{L})\end{array}$ & $\begin{array}{l}\text { Non- } \\
\text { detected } \\
\text { Value } \\
(\mu \mathrm{g} / \mathrm{L})\end{array}$ & $\begin{array}{l}\text { Drinking } \\
\text { Water } \\
M^{\prime} L^{b} \\
(\mu \mathrm{g} / \mathrm{L})\end{array}$ & $\begin{array}{l}\text { Frequency } \\
\text { of Detects } \\
>\text { Drinking } \\
\text { Water MCL }\end{array}$ & $\begin{array}{c}\text { NMED }^{c} \\
\text { Groundwater } \\
\text { Standard }^{d} \\
(\mu \mathrm{g} / \mathrm{L})\end{array}$ & $\begin{array}{l}\text { Frequency of } \\
\text { Detects }>\text { NMED } \\
\text { Groundwater } \\
\text { Standard }\end{array}$ \\
\hline \multicolumn{13}{|l|}{ Field Parameter } \\
\hline $\begin{array}{l}\text { Field Alkalinity (total } \\
\text { as } \mathrm{CaCO}_{3} \text { ) }\end{array}$ & 1 & 378 & $11 / 19 / 01$ & $\mathrm{NF}^{\mathrm{e}}$ & 1 & 1 & 39000 & $-^{f}$ & - & - & - & - \\
\hline Dissolved Oxygen & 1 & 378 & $11 / 19 / 01$ & NF & - & - & 2700 & - & - & - & - & - \\
\hline $\mathrm{pH}$ & 1 & 378 & $11 / 19 / 01$ & NF & 1 & 1 & 7.47 & - & $>6 \&<9$ & $0 / 1$ & $>6 \&<9$ & $0 / 1$ \\
\hline $\begin{array}{l}\text { Specific Conductance } \\
(\mu \mathrm{S} / \mathrm{cm})\end{array}$ & 1 & 378 & $11 / 19 / 01$ & NF & 1 & 1 & 92 & - & - & $0 / 1$ & - & $0 / 1$ \\
\hline Temperature $\left({ }^{\circ} \mathrm{C}\right)$ & 1 & 378 & $11 / 19 / 01$ & NF & 1 & 1 & 9.8 & - & - & $0 / 1$ & - & $0 / 1$ \\
\hline Turbidity (NTUg) & 1 & 378 & $11 / 19 / 01$ & NF & 1 & 1 & 0.30 & - & - & $0 / 1$ & - & $0 / 1$ \\
\hline
\end{tabular}

Analyte

N

Lab Alkalinity (total as

Aluminum

Aluminum

Ammonium (as $\mathrm{N}$ )

Antimony

Antimony

Arsenic

Arsenic

Barium

Barium

Beryllium

Beryllium

Boron

Boron

Bromide

\begin{tabular}{|c|c|c|c|c|}
\hline $11 / 19 / 01$ & $\mathrm{~F}^{\mathrm{h}}$ & 1 & 1 & 20400 \\
\hline $11 / 19 / 01$ & $\mathrm{~F}$ & 1 & 0 & - \\
\hline $11 / 19 / 01$ & NF & 1 & 0 & - \\
\hline $11 / 19 / 01$ & $F$ & 1 & 0 & - \\
\hline $11 / 19 / 01$ & $F$ & 1 & 0 & - \\
\hline $11 / 19 / 01$ & $\mathrm{NF}$ & 1 & 0 & - \\
\hline $11 / 19 / 01$ & $F$ & 1 & 0 & - \\
\hline $11 / 19 / 01$ & $\mathrm{NF}$ & 1 & 0 & - \\
\hline $11 / 19 / 01$ & $F$ & 1 & 1 & 74.9 \\
\hline $11 / 19 / 01$ & NF & 1 & 1 & 75.1 \\
\hline $11 / 19 / 01$ & $\mathrm{~F}$ & 1 & 0 & - \\
\hline $11 / 19 / 01$ & NF & 1 & 1 & 0.01 \\
\hline $11 / 19 / 01$ & $F$ & 1 & 0 & - \\
\hline $11 / 19 / 01$ & $\mathrm{NF}$ & 1 & 0 & - \\
\hline $11 / 19 / 01$ & $\mathrm{~F}$ & 1 & 0 & - \\
\hline
\end{tabular}

$[5$,

\begin{tabular}{|c|c}
\hline- & \\
\hline$[50]$ & \\
\hline$[50]$ & \\
\hline$[50]$ & \\
\hline 0.14$]$ & \\
\hline 0.09$]$ & \\
\hline$[5]$ & \\
\hline$[5]$ & \\
\hline- & 2000 \\
\hline- & \\
\hline$[0.2]$ & \\
\hline- & \\
\hline$[50]$ & \\
\hline$[50]$ & \\
\hline$[50]$ & \\
\hline
\end{tabular}


Table A-13 (continued)

\begin{tabular}{|c|c|c|c|c|c|c|c|c|c|c|c|c|}
\hline $\begin{array}{l}\text { Parameter } \\
\text { and } \\
\text { Analyte }\end{array}$ & Screen & $\begin{array}{l}\text { Depth } \\
(\mathrm{ft})^{\mathrm{a}}\end{array}$ & $\begin{array}{l}\text { Collection } \\
\text { Date }\end{array}$ & $\begin{array}{c}\text { Field } \\
\text { Preparation }\end{array}$ & $\begin{array}{l}\text { Number } \\
\text { of } \\
\text { Analyses }\end{array}$ & $\begin{array}{l}\text { Number } \\
\text { of } \\
\text { Detects }\end{array}$ & $\begin{array}{c}\text { Detected } \\
\text { Value } \\
\text { ( } \mu \mathrm{g} / \mathrm{L})\end{array}$ & $\begin{array}{l}\text { Non- } \\
\text { detected } \\
\text { Value } \\
(\mu \mathrm{g} / \mathrm{L})\end{array}$ & $\begin{array}{l}\text { Drinking } \\
\text { Water } \\
\text { MCL }^{\mathrm{b}} \\
(\mu \mathrm{g} / \mathrm{L})\end{array}$ & $\begin{array}{l}\text { Frequency } \\
\text { of Detects } \\
>\text { Drinking } \\
\text { Water MCL }\end{array}$ & $\begin{array}{c}\text { NMED }^{c} \\
\text { Groundwater } \\
\text { Standard }^{\mathrm{d}} \\
(\mu \mathrm{g} / \mathrm{L})\end{array}$ & $\begin{array}{l}\text { Frequency of } \\
\text { Detects }>\text { NMED } \\
\text { Groundwater } \\
\text { Standard }\end{array}$ \\
\hline Cadmium & 1 & 378 & $11 / 19 / 01$ & $\mathrm{~F}$ & 1 & 0 & - & [1] & 5 & $0 / 1$ & 10 & $0 / 1$ \\
\hline Cadmium & 1 & 378 & $11 / 19 / 01$ & NF & 1 & 0 & - & [1] & - & - & - & - \\
\hline Calcium & 1 & 378 & $11 / 19 / 01$ & $\mathrm{~F}$ & 1 & 1 & 9260 & - & - & - & - & - \\
\hline Calcium & 1 & 378 & $11 / 19 / 01$ & NF & 1 & 1 & 7970 & - & - & - & - & - \\
\hline Chloride & 1 & 378 & $11 / 19 / 01$ & $\mathrm{~F}$ & 1 & 1 & 998 & - & 250000 & $0 / 1$ & 250000 & $0 / 1$ \\
\hline Chromium & 1 & 378 & $11 / 19 / 01$ & $\mathrm{~F}$ & 1 & 1 & 1.82 & - & 100 & $0 / 1$ & 50 & $0 / 1$ \\
\hline Chromium & 1 & 378 & $11 / 19 / 01$ & NF & 1 & 0 & - & [4.55] & - & - & - & - \\
\hline Cobalt & 1 & 378 & $11 / 19 / 01$ & $\mathrm{~F}$ & 1 & 0 & - & [5] & - & - & 50 & $0 / 1$ \\
\hline Cobalt & 1 & 378 & $11 / 19 / 01$ & NF & 1 & 0 & - & [5] & - & - & - & - \\
\hline Copper & 1 & 378 & $11 / 19 / 01$ & $\mathrm{~F}$ & 1 & 0 & - & [5] & 1300 & $0 / 1$ & 1000 & $0 / 1$ \\
\hline Copper & 1 & 378 & $11 / 19 / 01$ & NF & 1 & 0 & - & [1.48] & - & - & - & - \\
\hline Cyanide (total) & 1 & 378 & $11 / 19 / 01$ & NF & 1 & 0 & - & [5] & - & - & - & - \\
\hline Fluoride & 1 & 378 & $11 / 19 / 01$ & $\mathrm{~F}$ & 1 & 0 & - & {$[50]$} & 4000 & $0 / 1$ & 1600 & $0 / 1$ \\
\hline Iron & 1 & 378 & $11 / 19 / 01$ & $\mathrm{~F}$ & 1 & 0 & - & {$[50]$} & 300 & $0 / 1$ & 1000 & $0 / 1$ \\
\hline Iron & 1 & 378 & $11 / 19 / 01$ & NF & 1 & 0 & - & {$[50]$} & - & - & - & - \\
\hline Lead & 1 & 378 & $11 / 19 / 01$ & $\mathrm{~F}$ & 1 & 0 & - & [2] & 15 & $0 / 1$ & 50 & $0 / 1$ \\
\hline Lead & 1 & 378 & $11 / 19 / 01$ & NF & 1 & 0 & - & [2] & - & - & - & - \\
\hline Magnesium & 1 & 378 & $11 / 19 / 01$ & $\mathrm{~F}$ & 1 & 1 & 1400 & - & - & - & - & - \\
\hline Magnesium & 1 & 378 & $11 / 19 / 01$ & NF & 1 & 1 & 1430 & - & - & - & - & - \\
\hline Manganese & 1 & 378 & $11 / 19 / 01$ & $\mathrm{~F}$ & 1 & 1 & 83.3 & - & 50 & $1 / 1$ & 200 & $0 / 1$ \\
\hline Manganese & 1 & 378 & $11 / 19 / 01$ & NF & 1 & 1 & 73.9 & - & - & - & - & - \\
\hline Mercury & 1 & 378 & $11 / 19 / 01$ & $\mathrm{~F}$ & 1 & 0 & - & {$[0.2]$} & 2 & $0 / 1$ & - & - \\
\hline Mercury & 1 & 378 & $11 / 19 / 01$ & NF & 1 & 0 & - & {$[0.2]$} & - & - & 2 & $0 / 1$ \\
\hline Molybdenum & 1 & 378 & $11 / 19 / 01$ & $\mathrm{~F}$ & 1 & 1 & 1.96 & - & - & - & - & - \\
\hline Molybdenum & 1 & 378 & $11 / 19 / 01$ & NF & 1 & 1 & 2.05 & - & - & - & - & - \\
\hline Nickel & 1 & 378 & $11 / 19 / 01$ & $\mathrm{~F}$ & 1 & 0 & - & [5] & 100 & $0 / 1$ & 200 & $0 / 1$ \\
\hline Nickel & 1 & 378 & $11 / 19 / 01$ & NF & 1 & 0 & - & [5] & - & - & - & - \\
\hline
\end{tabular}


Table A-13 (continued)

\begin{tabular}{|c|c|c|c|c|c|c|c|c|c|c|c|c|}
\hline $\begin{array}{l}\text { Parameter } \\
\text { and } \\
\text { Analyte }\end{array}$ & Screen & $\begin{array}{c}\text { Depth } \\
(\mathrm{ft})^{\mathrm{a}}\end{array}$ & $\begin{array}{l}\text { Collection } \\
\text { Date }\end{array}$ & $\begin{array}{c}\text { Field } \\
\text { Preparation }\end{array}$ & $\begin{array}{l}\text { Number } \\
\text { of } \\
\text { Analyses }\end{array}$ & $\begin{array}{c}\text { Number } \\
\text { of } \\
\text { Detects }\end{array}$ & $\begin{array}{c}\text { Detected } \\
\text { Value } \\
\text { ( } \mu \mathrm{g} / \mathrm{L})\end{array}$ & $\begin{array}{c}\text { Non- } \\
\text { detected } \\
\text { Value } \\
(\mu \mathrm{g} / \mathrm{L})\end{array}$ & $\begin{array}{l}\text { Drinking } \\
\text { Water } \\
M^{\prime} L^{b} \\
(\mu \mathrm{g} / \mathrm{L})\end{array}$ & $\begin{array}{l}\text { Frequency } \\
\text { of Detects } \\
>\text { Drinking } \\
\text { Water MCL }\end{array}$ & $\begin{array}{c}\text { NMED }^{c} \\
\text { Groundwater } \\
\text { Standard } \\
(\mu \mathrm{g} / \mathrm{L})\end{array}$ & $\begin{array}{l}\text { Frequency of } \\
\text { Detects }>\text { NMED } \\
\text { Groundwater } \\
\text { Standard }\end{array}$ \\
\hline Nitrate-Nitrite (as N) & 1 & 378 & $11 / 19 / 01$ & $\mathrm{~F}$ & 1 & 1 & 190 & - & 10000 & $0 / 1$ & - & - \\
\hline Oxalate & 1 & 378 & $11 / 19 / 01$ & $\mathrm{~F}$ & 1 & 0 & - & [600] & - & - & - & - \\
\hline Perchlorate & 1 & 378 & $11 / 19 / 01$ & $\mathrm{~F}$ & 1 & 0 & - & {$[4]$} & - & - & - & - \\
\hline Phosphorus (total) & 1 & 378 & $11 / 19 / 01$ & $\mathrm{~F}$ & 1 & 1 & 40 & - & - & - & - & - \\
\hline Potassium & 1 & 378 & $11 / 19 / 01$ & $\mathrm{~F}$ & 1 & 1 & 3060 & - & - & - & - & - \\
\hline Potassium & 1 & 378 & $11 / 19 / 01$ & NF & 1 & 1 & 3320 & - & - & - & - & - \\
\hline Selenium & 1 & 378 & $11 / 19 / 01$ & $\mathrm{~F}$ & 1 & 0 & - & [5] & 50 & $0 / 1$ & 50 & $0 / 1$ \\
\hline Selenium & 1 & 378 & $11 / 19 / 01$ & NF & 1 & 0 & - & {$[5]$} & - & - & - & - \\
\hline Silver & 1 & 378 & $11 / 19 / 01$ & $\mathrm{~F}$ & 1 & 0 & - & [5] & 100 & $0 / 1$ & 50 & $0 / 1$ \\
\hline Silver & 1 & 378 & $11 / 19 / 01$ & NF & 1 & 0 & - & [5] & - & - & - & - \\
\hline Silica & 1 & 378 & $11 / 19 / 01$ & $\mathrm{~F}$ & 1 & 1 & 65060 & - & - & - & - & - \\
\hline Sodium & 1 & 378 & $11 / 19 / 01$ & $\mathrm{~F}$ & 1 & 1 & 6390 & - & - & - & - & - \\
\hline Sodium & 1 & 378 & $11 / 19 / 01$ & NF & 1 & 1 & 6490 & - & - & - & - & - \\
\hline Strontium & 1 & 378 & $11 / 19 / 01$ & $\mathrm{~F}$ & 1 & 1 & 44.1 & - & - & - & - & - \\
\hline Strontium & 1 & 378 & $11 / 19 / 01$ & NF & 1 & 1 & 42.8 & - & - & - & - & - \\
\hline Sulfate & 1 & 378 & $11 / 19 / 01$ & $\mathrm{~F}$ & 1 & 1 & 1800 & - & 250000 & $0 / 1$ & 600000 & $0 / 1$ \\
\hline Thallium & 1 & 378 & $11 / 19 / 01$ & $\mathrm{~F}$ & 1 & 0 & - & {$[0.5]$} & 2 & $0 / 1$ & - & - \\
\hline Thallium & 1 & 378 & $11 / 19 / 01$ & NF & 1 & 0 & - & {$[0.5]$} & - & - & - & - \\
\hline $\begin{array}{l}\text { Total Kjeldahl } \\
\text { Nitrogen }\end{array}$ & 1 & 378 & $11 / 19 / 01$ & $\mathrm{~F}$ & 1 & 1 & 250 & - & - & - & - & - \\
\hline $\begin{array}{l}\text { Total Kjeldahl } \\
\text { Nitrogen }\end{array}$ & 1 & 378 & $11 / 19 / 01$ & NF & 1 & 1 & 200 & - & - & - & - & - \\
\hline Uranium & 1 & 378 & $11 / 19 / 01$ & $\mathrm{~F}$ & 1 & 0 & - & {$[0.2]$} & 20 & $0 / 1$ & 5000 & $0 / 1$ \\
\hline Uranium & 1 & 378 & $11 / 19 / 01$ & NF & 1 & 0 & - & {$[0.2]$} & - & - & - & - \\
\hline Vanadium & 1 & 378 & $11 / 19 / 01$ & $\mathrm{~F}$ & 1 & 0 & - & [1.09] & - & - & - & - \\
\hline Vanadium & 1 & 378 & $11 / 19 / 01$ & NF & 1 & 1 & 0.764 & - & - & - & - & - \\
\hline Zinc & 1 & 378 & $11 / 19 / 01$ & $\mathrm{~F}$ & 1 & 1 & 23.7 & - & 5000 & $0 / 1$ & 10000 & $0 / 1$ \\
\hline Zinc & 1 & 378 & $11 / 19 / 01$ & NF & 1 & 1 & 21.2 & - & - & - & - & - \\
\hline
\end{tabular}


Table A-13 (continued)

\begin{tabular}{|c|c|c|c|c|c|c|c|c|c|c|c|c|}
\hline $\begin{array}{c}\text { Parameter } \\
\text { and } \\
\text { Analyte }\end{array}$ & Screen & $\begin{array}{c}\text { Depth } \\
(\mathrm{ft})^{\mathrm{a}}\end{array}$ & $\begin{array}{c}\text { Collection } \\
\text { Date }\end{array}$ & $\begin{array}{c}\text { Field } \\
\text { Preparation }\end{array}$ & $\begin{array}{l}\text { Number } \\
\text { of } \\
\text { Analyses }\end{array}$ & $\begin{array}{c}\text { Number } \\
\text { of } \\
\text { Detects }\end{array}$ & $\begin{array}{c}\text { Detected } \\
\text { Value } \\
(\mu \mathrm{g} / \mathrm{L})\end{array}$ & $\begin{array}{c}\text { Non- } \\
\text { detected } \\
\text { Value } \\
(\mu \mathrm{g} / \mathrm{L})\end{array}$ & $\begin{array}{l}\text { Drinking } \\
\text { Water } \\
M^{\prime} L^{b} \\
(\mu \mathrm{g} / \mathrm{L})\end{array}$ & $\begin{array}{l}\text { Frequency } \\
\text { of Detects } \\
>\text { Drinking } \\
\text { Water MCL }\end{array}$ & $\begin{array}{c}\text { NMED }^{c} \\
\text { Groundwater } \\
\text { Standard } \\
(\mu \mathrm{g} / \mathrm{L})\end{array}$ & $\begin{array}{c}\text { Frequency of } \\
\text { Detects }>\text { NMED } \\
\text { Groundwater } \\
\text { Standard }\end{array}$ \\
\hline \multicolumn{13}{|c|}{ Stable Isotope (\%o) } \\
\hline$\delta \mathrm{D}$ & 1 & 378 & $11 / 19 / 01$ & $\mathrm{NF}$ & 1 & 1 & - & - & - & - & - & - \\
\hline$\delta^{15} \mathrm{~N}\left(\mathrm{NO}_{3}\right)$ & 1 & 378 & $11 / 19 / 01$ & $\mathrm{NF}$ & 1 & 1 & +3.3 & - & - & - & - & - \\
\hline$\delta^{18} \mathrm{O}$ & 1 & 378 & $11 / 19 / 01$ & $\mathrm{NF}$ & 1 & 1 & - & - & - & - & - & - \\
\hline
\end{tabular}

a The static water level for the regional aquifer at R-7 was $902.8 \mathrm{ft}$ when the well was drilled.

${ }^{\mathrm{b}} \mathrm{MCL}=$ Maximum contaminant level. US Environmental Protection Agency (EPA) MCLs are from National Primary Drinking Water Regulations, 40 CFR Part 141. US EPA secondary MCLs are from National Secondary Drinking Water Regulations, 40 CFR Part 143. State of New Mexico MCLs are from Drinking Water Regulations, 20 NMAC 7.1.

${ }^{c}$ NMED $=$ New Mexico Environment Department.

d State of New Mexico groundwater standards are from New Mexico Water Quality Control Commission Regulations, Ground and Surface Water Protection, 20 NMAC 6.2.

$\mathrm{NF}=$ Nonfiltered

f $-=$ Not available or not applicable.

${ }^{g} \mathrm{NTU}=$ Nephelometric turbidity unit.

${ }^{\mathrm{h}} \mathrm{F}=$ Filtered 
Table A-14

Well R-7 Screen 3 Third Round Sample Results: Data Summary for Inorganic Chemicals

\begin{tabular}{|c|c|c|c|c|c|c|c|c|c|c|c|c|}
\hline $\begin{array}{l}\text { Parameter } \\
\text { and } \\
\text { Analyte }\end{array}$ & Screen & $\begin{array}{c}\text { Depth } \\
\text { (ft) }\end{array}$ & $\begin{array}{l}\text { Collection } \\
\text { Date }\end{array}$ & $\begin{array}{c}\text { Field } \\
\text { Preparation }\end{array}$ & $\begin{array}{c}\text { Number } \\
\text { of } \\
\text { Analyses }\end{array}$ & $\begin{array}{c}\text { Number } \\
\text { of } \\
\text { Detects }\end{array}$ & $\begin{array}{c}\text { Detected } \\
\text { Value } \\
\text { ( } \mu \mathrm{g} / \mathrm{L})\end{array}$ & $\begin{array}{c}\text { Non- } \\
\text { detected } \\
\text { Value } \\
(\mu \mathrm{g} / \mathrm{L})\end{array}$ & $\begin{array}{l}\text { Drinking } \\
\text { Water } \\
M L^{b} \\
(\mu g / L)\end{array}$ & $\begin{array}{l}\text { Frequency } \\
\text { of Detects } \\
>\text { Drinking } \\
\text { Water MCL }\end{array}$ & $\begin{array}{c}\text { NMED }^{c} \\
\text { Groundwater } \\
\text { Standard }^{\mathrm{d}} \\
(\mu \mathrm{g} / \mathrm{L})\end{array}$ & $\begin{array}{c}\text { Frequency of } \\
\text { Detects }>\text { NMED } \\
\text { Groundwater } \\
\text { Standard }\end{array}$ \\
\hline \multicolumn{13}{|l|}{ Field Parameter } \\
\hline $\begin{array}{l}\text { Field Alkalinity (total } \\
\text { as } \mathrm{CaCO}_{3} \text { ) }\end{array}$ & 3 & 915 & $11 / 27 / 01$ & $\mathrm{NF}^{\mathrm{e}}$ & 1 & 1 & 116000 & $-^{f}$ & - & - & - & - \\
\hline Dissolved Oxygen & 3 & 915 & $11 / 27 / 01$ & NF & - & - & 1900 & - & - & - & - & - \\
\hline $\mathrm{pH}$ & 3 & 915 & $11 / 27 / 01$ & $\mathrm{NF}$ & 1 & 1 & 7.24 & - & $>6 \&<9$ & $0 / 1$ & $>6 \&<9$ & $0 / 1$ \\
\hline $\begin{array}{l}\text { Specific Conductance } \\
(\mu \mathrm{S} / \mathrm{cm})\end{array}$ & 3 & 915 & $11 / 27 / 01$ & NF & 1 & 1 & 227 & - & - & $0 / 1$ & - & $0 / 1$ \\
\hline Temperature $\left({ }^{\circ} \mathrm{C}\right)$ & 3 & 915 & $11 / 27 / 01$ & NF & 1 & 1 & 10.5 & - & - & $0 / 1$ & - & $0 / 1$ \\
\hline Turbidity (NTU9) & 3 & 915 & $11 / 27 / 01$ & NF & 1 & 1 & 2.90 & - & - & $0 / 1$ & - & $0 / 1$ \\
\hline
\end{tabular}

Analyte

\begin{tabular}{|c|c|c|c|c|c|c|c|c|c|c|c|c|}
\hline $\begin{array}{l}\text { Lab Alkalinity (total as } \\
\mathrm{CaCO}_{3} \text { ) }\end{array}$ & 3 & 915 & $11 / 27 / 01$ & $\mathrm{~F}^{\mathrm{h}}$ & 1 & 1 & 79100 & - & - & - & - & - \\
\hline Aluminum & 3 & 915 & $11 / 27 / 01$ & $\mathrm{~F}$ & 1 & 0 & - & [50] & 50 & $0 / 1$ & 5000 & $0 / 1$ \\
\hline Aluminum & 3 & 915 & $11 / 27 / 01$ & NF & 1 & 0 & - & [50] & - & - & - & - \\
\hline Ammonium (as N) & 3 & 915 & $11 / 27 / 01$ & $\mathrm{~F}$ & 1 & 1 & 450 & - & - & - & - & - \\
\hline Antimony & 3 & 915 & $11 / 27 / 01$ & $\mathrm{~F}$ & 1 & 0 & - & {$[0.41]$} & 6 & $0 / 1$ & - & - \\
\hline Antimony & 3 & 915 & $11 / 27 / 01$ & NF & 1 & 0 & - & {$[0.16]$} & - & - & - & 一 \\
\hline Arsenic & 3 & 915 & $11 / 27 / 01$ & $\mathrm{~F}$ & 1 & 0 & - & [5] & 50 & $0 / 1$ & 100 & $0 / 1$ \\
\hline Arsenic & 3 & 915 & $11 / 27 / 01$ & NF & 1 & 1 & 3.48 & - & - & - & - & - \\
\hline Barium & 3 & 915 & $11 / 27 / 01$ & $\mathrm{~F}$ & 1 & 1 & 216 & - & 2000 & $0 / 1$ & 1000 & $0 / 1$ \\
\hline Barium & 3 & 915 & $11 / 27 / 01$ & NF & 1 & 1 & 226 & - & - & - & - & - \\
\hline Beryllium & 3 & 915 & $11 / 27 / 01$ & $\mathrm{~F}$ & 1 & 0 & - & {$[0.2]$} & 4 & $0 / 1$ & - & - \\
\hline Beryllium & 3 & 915 & 11/27/01 & NF & 1 & 1 & 0.01 & - & - & - & - & - \\
\hline Boron & 3 & 915 & $11 / 27 / 01$ & $\mathrm{~F}$ & 1 & 1 & 8.21 & - & - & - & 750 & $0 / 1$ \\
\hline Boron & 3 & 915 & $11 / 27 / 01$ & NF & 1 & 1 & 7.97 & - & - & - & - & - \\
\hline Bromide & 3 & 915 & $11 / 27 / 01$ & $\mathrm{~F}$ & 1 & 0 & - & [50] & - & - & - & - \\
\hline
\end{tabular}


Table A-14 (continued)

\begin{tabular}{|c|c|c|c|c|c|c|c|c|c|c|c|c|}
\hline $\begin{array}{l}\text { Parameter } \\
\text { and } \\
\text { Analyte }\end{array}$ & Screen & $\begin{array}{l}\text { Depth } \\
(\mathrm{ft})^{\mathrm{a}}\end{array}$ & $\begin{array}{l}\text { Collection } \\
\text { Date }\end{array}$ & $\begin{array}{c}\text { Field } \\
\text { Preparation }\end{array}$ & $\begin{array}{c}\text { Number } \\
\text { of } \\
\text { Analyses }\end{array}$ & $\begin{array}{l}\text { Number } \\
\text { of } \\
\text { Detects }\end{array}$ & $\begin{array}{c}\text { Detected } \\
\text { Value } \\
(\mu \mathrm{g} / \mathrm{L})\end{array}$ & $\begin{array}{c}\text { Non- } \\
\text { detected } \\
\text { Value } \\
(\mu \mathrm{g} / \mathrm{L})\end{array}$ & $\begin{array}{l}\text { Drinking } \\
\text { Water } \\
\text { MCL }^{\mathrm{b}} \\
(\mu \mathrm{g} / \mathrm{L})\end{array}$ & $\begin{array}{l}\text { Frequency } \\
\text { of Detects } \\
>\text { Drinking } \\
\text { Water MCL }\end{array}$ & $\begin{array}{c}\text { NMED }^{c} \\
\text { Groundwater } \\
\text { Standard }^{\mathrm{d}} \\
(\mu \mathrm{g} / \mathrm{L})\end{array}$ & $\begin{array}{l}\text { Frequency of } \\
\text { Detects }>\text { NMED } \\
\text { Groundwater } \\
\text { Standard }\end{array}$ \\
\hline Cadmium & 3 & 915 & $11 / 27 / 01$ & $\mathrm{~F}$ & 1 & 0 & - & [1] & 5 & $0 / 1$ & 10 & $0 / 1$ \\
\hline Cadmium & 3 & 915 & $11 / 27 / 01$ & NF & 1 & 1 & 0.07 & - & - & - & - & - \\
\hline Calcium & 3 & 915 & $11 / 27 / 01$ & $\mathrm{~F}$ & 1 & 1 & 18900 & - & - & - & - & - \\
\hline Calcium & 3 & 915 & $11 / 27 / 01$ & NF & 1 & 1 & 19300 & - & - & - & - & - \\
\hline Chloride & 3 & 915 & $11 / 27 / 01$ & $\mathrm{~F}$ & 1 & 1 & 1380 & - & 250000 & $0 / 1$ & 250000 & $0 / 1$ \\
\hline Chromium & 3 & 915 & $11 / 27 / 01$ & $\mathrm{~F}$ & 1 & 0 & - & {$[5]$} & 100 & $0 / 1$ & 50 & $0 / 1$ \\
\hline Chromium & 3 & 915 & $11 / 27 / 01$ & NF & 1 & 1 & 3.23 & - & - & - & - & - \\
\hline Cobalt & 3 & 915 & $11 / 27 / 01$ & $\mathrm{~F}$ & 1 & 1 & 5.83 & - & - & - & 50 & $0 / 1$ \\
\hline Cobalt & 3 & 915 & $11 / 27 / 01$ & NF & 1 & 1 & 6.13 & - & - & - & - & - \\
\hline Copper & 3 & 915 & $11 / 27 / 01$ & $\mathrm{~F}$ & 1 & 0 & - & [5] & 1300 & $0 / 1$ & 1000 & $0 / 1$ \\
\hline Copper & 3 & 915 & $11 / 27 / 01$ & NF & 1 & 1 & 1.76 & - & - & - & - & - \\
\hline Cyanide (total) & 3 & 915 & $11 / 27 / 01$ & NF & 1 & 0 & - & [5] & - & - & - & - \\
\hline Fluoride & 3 & 915 & $11 / 27 / 01$ & $\mathrm{~F}$ & 1 & 0 & - & [50] & 4000 & $0 / 1$ & 1600 & $0 / 1$ \\
\hline Iron & 3 & 915 & $11 / 27 / 01$ & $\mathrm{~F}$ & 1 & 1 & 12400 & - & 300 & $1 / 1$ & 1000 & $1 / 1$ \\
\hline Iron & 3 & 915 & $11 / 27 / 01$ & NF & 1 & 1 & 13600 & - & - & - & - & - \\
\hline Lead & 3 & 915 & $11 / 27 / 01$ & $\mathrm{~F}$ & 1 & 0 & - & {$[2]$} & 15 & $0 / 1$ & 50 & $0 / 1$ \\
\hline Lead & 3 & 915 & $11 / 27 / 01$ & NF & 1 & 1 & 0.26 & - & - & - & - & - \\
\hline Magnesium & 3 & 915 & $11 / 27 / 01$ & $\mathrm{~F}$ & 1 & 1 & 5050 & - & - & - & - & - \\
\hline Magnesium & 3 & 915 & $11 / 27 / 01$ & NF & 1 & 1 & 5170 & - & - & - & - & - \\
\hline Manganese & 3 & 915 & $11 / 27 / 01$ & $\mathrm{~F}$ & 1 & 1 & 3080 & - & 50 & $1 / 1$ & 200 & $1 / 1$ \\
\hline Manganese & 3 & 915 & $11 / 27 / 01$ & NF & 1 & 1 & 3030 & - & - & - & - & - \\
\hline Mercury & 3 & 915 & $11 / 27 / 01$ & $\mathrm{~F}$ & 1 & 0 & - & {$[0.2]$} & 2 & $0 / 1$ & - & - \\
\hline Mercury & 3 & 915 & $11 / 27 / 01$ & NF & 1 & 0 & - & {$[0.2]$} & - & - & 2 & $0 / 1$ \\
\hline Molybdenum & 3 & 915 & $11 / 27 / 01$ & $\mathrm{~F}$ & 1 & 1 & 15.5 & - & - & - & - & - \\
\hline Molybdenum & 3 & 915 & $11 / 27 / 01$ & NF & 1 & 1 & 15.4 & - & - & - & - & - \\
\hline Nickel & 3 & 915 & $11 / 27 / 01$ & $\mathrm{~F}$ & 1 & 1 & 47.8 & - & 100 & $0 / 1$ & 200 & $0 / 1$ \\
\hline Nickel & 3 & 915 & $11 / 27 / 01$ & NF & 1 & 1 & 50.2 & - & - & - & - & - \\
\hline
\end{tabular}


Table A-14 (continued)

\begin{tabular}{|c|c|c|c|c|c|c|c|c|c|c|c|c|}
\hline $\begin{array}{l}\text { Parameter } \\
\text { and } \\
\text { Analyte }\end{array}$ & Screen & $\begin{array}{c}\text { Depth } \\
(\mathrm{ft})^{\mathrm{a}}\end{array}$ & $\begin{array}{l}\text { Collection } \\
\text { Date }\end{array}$ & $\begin{array}{c}\text { Field } \\
\text { Preparation }\end{array}$ & $\begin{array}{c}\text { Number } \\
\text { of } \\
\text { Analyses }\end{array}$ & $\begin{array}{l}\text { Number } \\
\text { of } \\
\text { Detects }\end{array}$ & $\begin{array}{l}\text { Detected } \\
\text { Value } \\
\text { ( } \mu \mathrm{g} / \mathrm{L})\end{array}$ & $\begin{array}{c}\text { Non- } \\
\text { detected } \\
\text { Value } \\
(\mu \mathrm{g} / \mathrm{L})\end{array}$ & $\begin{array}{l}\text { Drinking } \\
\text { Water } \\
M^{\prime} L^{b} \\
(\mu \mathrm{g} / \mathrm{L})\end{array}$ & $\begin{array}{l}\text { Frequency } \\
\text { of Detects } \\
>\text { Drinking } \\
\text { Water MCL }\end{array}$ & $\begin{array}{c}\text { NMED }^{c} \\
\text { Groundwater } \\
\text { Standard }^{d} \\
(\mu \mathrm{g} / \mathrm{L})\end{array}$ & $\begin{array}{l}\text { Frequency of } \\
\text { Detects }>\text { NMED } \\
\text { Groundwater } \\
\text { Standard }\end{array}$ \\
\hline Nitrate-Nitrite (as N) & 3 & 915 & $11 / 27 / 01$ & $\mathrm{~F}$ & 1 & 1 & 50 & - & 10000 & $0 / 1$ & - & - \\
\hline Oxalate & 3 & 915 & $11 / 27 / 01$ & $\mathrm{~F}$ & 1 & 0 & - & [600] & - & - & - & - \\
\hline Perchlorate & 3 & 915 & $11 / 27 / 01$ & $\mathrm{~F}$ & 1 & 0 & - & [4] & - & - & - & - \\
\hline Phosphorus (total) & 3 & 915 & $11 / 27 / 01$ & $\mathrm{~F}$ & 1 & 1 & 70 & - & - & - & - & - \\
\hline Potassium & 3 & 915 & $11 / 27 / 01$ & $\mathrm{~F}$ & 1 & 1 & 2700 & - & - & - & - & - \\
\hline Potassium & 3 & 915 & $11 / 27 / 01$ & NF & 1 & 1 & 2630 & - & - & - & - & - \\
\hline Selenium & 3 & 915 & $11 / 27 / 01$ & $\mathrm{~F}$ & 1 & 0 & - & [5] & 50 & $0 / 1$ & 50 & $0 / 1$ \\
\hline Selenium & 3 & 915 & $11 / 27 / 01$ & NF & 1 & 1 & 3.65 & - & - & - & - & - \\
\hline Silver & 3 & 915 & $11 / 27 / 01$ & $\mathrm{~F}$ & 1 & 0 & - & [5] & 100 & $0 / 1$ & 50 & $0 / 1$ \\
\hline Silver & 3 & 915 & $11 / 27 / 01$ & NF & 1 & 0 & - & [5] & - & - & - & - \\
\hline Silica & 3 & 915 & $11 / 27 / 01$ & $\mathrm{~F}$ & 1 & 1 & 48150 & - & - & - & - & - \\
\hline Silica & 3 & 915 & $11 / 27 / 01$ & NF & 1 & 1 & 49220 & - & - & - & - & - \\
\hline Sodium & 3 & 915 & $11 / 27 / 01$ & $\mathrm{~F}$ & 1 & 1 & 12200 & - & - & - & - & - \\
\hline Sodium & 3 & 915 & $11 / 27 / 01$ & NF & 1 & 1 & 12500 & - & - & - & - & - \\
\hline Strontium & 3 & 915 & $11 / 27 / 01$ & $\mathrm{~F}$ & 1 & 1 & 117 & - & - & - & - & - \\
\hline Strontium & 3 & 915 & $11 / 27 / 01$ & NF & 1 & 1 & 120 & - & - & - & - & - \\
\hline Sulfate & 3 & 915 & $11 / 27 / 01$ & $\mathrm{~F}$ & 1 & 0 & - & [200] & 250000 & $0 / 1$ & 600000 & $0 / 1$ \\
\hline Thallium & 3 & 915 & $11 / 27 / 01$ & $\mathrm{~F}$ & 1 & 0 & - & {$[0.5]$} & 2 & $0 / 1$ & - & - \\
\hline Thallium & 3 & 915 & $11 / 27 / 01$ & NF & 1 & 0 & - & {$[0.5]$} & - & - & - & - \\
\hline $\begin{array}{l}\text { Total Kjeldahl } \\
\text { Nitrogen }\end{array}$ & 3 & 915 & $11 / 27 / 01$ & $\mathrm{~F}$ & 1 & 1 & 940 & - & - & - & - & - \\
\hline $\begin{array}{l}\text { Total Kjeldahl } \\
\text { Nitrogen }\end{array}$ & 3 & 915 & $11 / 27 / 01$ & NF & 1 & 1 & 1180 & - & - & - & - & - \\
\hline Uranium & 3 & 915 & $11 / 27 / 01$ & $\mathrm{~F}$ & 1 & 0 & - & {$[0.2]$} & 20 & $0 / 1$ & 5000 & $0 / 1$ \\
\hline Uranium & 3 & 915 & $11 / 27 / 01$ & NF & 1 & 0 & - & {$[0.2]$} & - & - & - & - \\
\hline Vanadium & 3 & 915 & $11 / 27 / 01$ & $\mathrm{~F}$ & 1 & 0 & - & [0.523] & - & - & - & - \\
\hline Vanadium & 3 & 915 & $11 / 27 / 01$ & NF & 1 & 0 & - & [0.649] & - & - & - & - \\
\hline
\end{tabular}


Table A-14 (continued)

\begin{tabular}{|c|c|c|c|c|c|c|c|c|c|c|c|c|}
\hline $\begin{array}{c}\text { Parameter } \\
\text { and } \\
\text { Analyte }\end{array}$ & Screen & $\begin{array}{l}\text { Depth } \\
(\mathrm{ft})^{a}\end{array}$ & $\begin{array}{c}\text { Collection } \\
\text { Date }\end{array}$ & $\begin{array}{c}\text { Field } \\
\text { Preparation }\end{array}$ & $\begin{array}{c}\text { Number } \\
\text { of } \\
\text { Analyses }\end{array}$ & $\begin{array}{l}\text { Number } \\
\text { of } \\
\text { Detects }\end{array}$ & $\begin{array}{c}\text { Detected } \\
\text { Value } \\
(\mu \mathrm{g} / \mathrm{L})\end{array}$ & $\begin{array}{l}\text { Non- } \\
\text { detected } \\
\text { Value } \\
(\mu \mathrm{g} / \mathrm{L})\end{array}$ & $\begin{array}{l}\text { Drinking } \\
\text { Water } \\
\text { MCL }^{\mathrm{b}} \\
(\mu \mathrm{g} / \mathrm{L})\end{array}$ & $\begin{array}{l}\text { Frequency } \\
\text { of Detects } \\
>\text { Drinking } \\
\text { Water MCL }\end{array}$ & $\begin{array}{c}\text { NMED }^{c} \\
\text { Groundwater } \\
\text { Standard }^{d} \\
(\mu \mathrm{g} / \mathrm{L})\end{array}$ & $\begin{array}{l}\text { Frequency of } \\
\text { Detects }>\text { NMED } \\
\text { Groundwater } \\
\text { Standard }\end{array}$ \\
\hline Zinc & 3 & 915 & $11 / 27 / 01$ & $\mathrm{~F}$ & 1 & 1 & 30.5 & - & 5000 & $0 / 1$ & 10000 & $0 / 1$ \\
\hline Zinc & 3 & 915 & $11 / 27 / 01$ & $\mathrm{NF}$ & 1 & 1 & 36 & - & - & - & - & - \\
\hline \multicolumn{13}{|c|}{ Stable Isotope (\%o) } \\
\hline$\delta \mathrm{D}$ & 3 & 915 & $11 / 27 / 01$ & NF & 1 & 1 & -79 & - & - & - & - & - \\
\hline$\delta^{15} \mathrm{~N}\left(\mathrm{NO}_{3}\right)$ & 3 & 915 & $11 / 27 / 01$ & NF & 1 & 1 & +1.7 & - & - & - & - & - \\
\hline$\delta^{18} \mathrm{O}$ & 3 & 915 & $11 / 27 / 01$ & NF & 1 & 1 & -11.5 & - & - & - & - & - \\
\hline
\end{tabular}

${ }^{\text {a }}$ The static water level for the regional aquifer at R-7 was $902.8 \mathrm{ft}$ when the well was drilled.

${ }^{\mathrm{b}} \mathrm{MCL}=$ Maximum contaminant level. US Environmental Protection Agency (EPA) MCLs are from National Primary Drinking Water Regulations, 40 CFR Part 141. US EPA secondary MCLs are from National Secondary Drinking Water Regulations, 40 CFR Part 143. State of New Mexico MCLs are from Drinking Water Regulations, 20 NMAC 7.1.

${ }^{c}$ NMED $=$ New Mexico Environment Department.

d State of New Mexico groundwater standards are from New Mexico Water Quality Control Commission Regulations, Ground and Surface Water Protection, 20 NMAC 6.2.

${ }^{\mathrm{e} F}=$ Nonfiltered.

$\underset{\omega}{\omega} \quad f \quad=$ Not available or not applicable.

${ }^{\mathrm{g}} \mathrm{NTU}=$ Nephelometric turbidity unit

${ }^{\mathrm{h}} \mathrm{F}=$ Filtered 
Table A-15

Regional Well R-7 Screen 1 Third Round Sample Results: Data Summary for Detected Organic Chemicals

\begin{tabular}{|c|c|c|c|c|c|c|c|c|c|c|c|c|}
\hline Analyte & Screen & $\begin{array}{l}\text { Depth } \\
\text { (ft) }\end{array}$ & $\begin{array}{c}\text { Collection } \\
\text { Date }\end{array}$ & $\begin{array}{c}\text { Field } \\
\text { Preparation }\end{array}$ & $\begin{array}{c}\text { Number } \\
\text { of } \\
\text { Analyses }\end{array}$ & $\begin{array}{c}\text { Number } \\
\text { of } \\
\text { Detects }\end{array}$ & $\begin{array}{c}\text { Detected } \\
\text { Value } \\
\text { ( } \mu \mathrm{g} / \mathrm{L})\end{array}$ & $\begin{array}{c}\text { Non- } \\
\text { detected } \\
\text { Value } \\
(\mu \mathrm{g} / \mathrm{L})\end{array}$ & $\begin{array}{l}\text { Drinking } \\
\text { Water } \\
\text { MCL }^{\mathrm{b}} \\
(\mu \mathrm{g} / \mathrm{L})\end{array}$ & $\begin{array}{l}\text { Frequency } \\
\text { of Detects } \\
>\text { Drinking } \\
\text { Water MCL }\end{array}$ & $\begin{array}{l}\text { NMEDc } \\
\text { Groundwater } \\
\text { Standard } \\
(\mu \mathrm{g} / \mathrm{L})\end{array}$ & $\begin{array}{c}\text { Frequency of } \\
\text { Detects }>\text { NMED } \\
\text { Groundwater } \\
\text { Standard }\end{array}$ \\
\hline $\begin{array}{l}\text { Dissolved Organic } \\
\text { Carbon }\end{array}$ & 1 & 378 & $11 / 19 / 01$ & $\mathrm{~F}^{\mathrm{e}}$ & 1 & 1 & 850 & $-^{f}$ & - & - & - & - \\
\hline Total Organic Carbon & 1 & 378 & $11 / 19 / 01$ & $\mathrm{NF}^{\mathrm{g}}$ & 1 & 1 & 678 & - & - & - & - & - \\
\hline
\end{tabular}

The static water level for the regional aquifer at R-7 was $902.8 \mathrm{ft}$ when the well was drilled.

${ }^{\mathrm{b}} \mathrm{MCL}=$ Maximum contaminant level. US Environmental Protection Agency (EPA) MCLs are from National Primary Drinking Water Regulations, 40 CFR Part 141. US EPA secondary MCLs are from National Secondary Drinking Water Regulations, 40 CFR Part 143. State of New Mexico MCLs are from Drinking Water Regulations, 20 NMAC 7.1.

C NMED = New Mexico Environment Department.

d State of New Mexico groundwater standards are from New Mexico Water Quality Control Commission Regulations, Ground and Surface Water Protection, 20 NMAC 6.2.

$\mathrm{e} F=$ Filtered.

$f-=$ Not available or not applicable

${ }^{\mathrm{g}} \mathrm{NF}=$ Nonfiltered. 
Table A-16

Regional Well R-7 Screen 3 Third Round Sample Results: Data Summary for Detected Organic Chemicals

\begin{tabular}{|c|c|c|c|c|c|c|c|c|c|c|c|c|}
\hline Analyte & Screen & $\begin{array}{c}\text { Depth } \\
(\mathrm{ft})^{a}\end{array}$ & $\begin{array}{l}\text { Collection } \\
\text { Date }\end{array}$ & $\begin{array}{c}\text { Field } \\
\text { Preparation }\end{array}$ & $\begin{array}{c}\text { Number } \\
\text { of } \\
\text { Analyses }\end{array}$ & $\begin{array}{c}\text { Number } \\
\text { of } \\
\text { Detects }\end{array}$ & $\begin{array}{c}\text { Detected } \\
\text { Value } \\
(\mu \mathrm{g} / \mathrm{L})\end{array}$ & $\begin{array}{c}\text { Non- } \\
\text { detected } \\
\text { Value } \\
(\mu \mathrm{g} / \mathrm{L})\end{array}$ & $\begin{array}{l}\text { Drinking } \\
\text { Water } \\
\mathrm{MCL}^{\mathrm{b}} \\
(\mu \mathrm{g} / \mathrm{L})\end{array}$ & $\begin{array}{l}\text { Frequency } \\
\text { of Detects } \\
>\text { Drinking } \\
\text { Water MCL }\end{array}$ & $\begin{array}{c}\text { NMED }^{c} \\
\text { Groundwater } \\
\text { Standard }^{\mathrm{d}} \\
(\mu \mathrm{g} / \mathrm{L})\end{array}$ & $\begin{array}{c}\text { Frequency of } \\
\text { Detects }>\text { NMED } \\
\text { Groundwater } \\
\text { Standard }\end{array}$ \\
\hline DDT[4,4'-] & 3 & 915 & $11 / 27 / 01$ & $\mathrm{NF}^{\mathrm{e}}$ & 1 & 1 & 0.0077 & $-^{f}$ & - & - & - & - \\
\hline $\begin{array}{l}\text { Dissolved Organic } \\
\text { Carbon }\end{array}$ & 3 & 915 & $11 / 27 / 01$ & $\mathrm{~F}^{\mathrm{g}}$ & 1 & 1 & 4000 & - & - & - & - & - \\
\hline $\begin{array}{l}\text { Humic Substances, } \\
\text { Hydrophilic Acids }\end{array}$ & 3 & 915 & $11 / 27 / 01$ & $\mathrm{~F}$ & 1 & 1 & 1600 & - & - & - & - & - \\
\hline $\begin{array}{l}\text { Humic Substances, } \\
\text { Hydrophilic Bases }\end{array}$ & 3 & 915 & $11 / 27 / 01$ & $\mathrm{~F}$ & 1 & 1 & - & [100] & - & - & - & - \\
\hline $\begin{array}{l}\text { Humic Substances, } \\
\text { Hydrophilic Neutrals }\end{array}$ & 3 & 915 & $11 / 27 / 01$ & $\mathrm{~F}$ & 1 & 1 & 400 & - & - & - & - & - \\
\hline $\begin{array}{l}\text { Humic Substances, } \\
\text { Hydrophilic Total }\end{array}$ & 3 & 915 & $11 / 27 / 01$ & $\mathrm{~F}$ & 1 & 1 & 2000 & - & - & - & - & - \\
\hline $\begin{array}{l}\text { Humic Substances, } \\
\text { Hydrophobic Acids }\end{array}$ & 3 & 915 & $11 / 27 / 01$ & $\mathrm{~F}$ & 1 & 1 & 900 & - & - & - & - & - \\
\hline $\begin{array}{l}\text { Humic Substances, } \\
\text { Hydrophobic Bases }\end{array}$ & 3 & 915 & $11 / 27 / 01$ & $\mathrm{~F}$ & 1 & 1 & 200 & - & - & - & - & - \\
\hline $\begin{array}{l}\text { Humic Substances, } \\
\text { Hydrophobic Neutrals }\end{array}$ & 3 & 915 & $11 / 27 / 01$ & $\mathrm{~F}$ & 1 & 1 & 900 & - & - & - & - & - \\
\hline $\begin{array}{l}\text { Humic Substances, } \\
\text { Hydrophobic Total }\end{array}$ & 3 & 915 & $11 / 27 / 01$ & $\mathrm{~F}$ & 1 & 1 & 2000 & - & - & - & - & - \\
\hline Isopropylbenzene & 3 & 915 & $11 / 27 / 01$ & $\mathrm{NF}$ & 1 & 1 & 0.55 & - & - & - & - & - \\
\hline Total Organic Carbon & 3 & 915 & $11 / 27 / 01$ & NF & 1 & 1 & 6490 & - & - & - & - & - \\
\hline
\end{tabular}

${ }^{\text {a }}$ The static water level for the regional aquifer at R-7 was $902.8 \mathrm{ft}$ when the well was drilled.

${ }^{\mathrm{b}} \mathrm{MCL}=$ Maximum contaminant level. US Environmental Protection Agency (EPA) MCLs are from National Primary Drinking Water Regulations, 40 CFR Part 141. US EPA secondary MCLs are from National Secondary Drinking Water Regulations, 40 CFR Part 143. State of New Mexico MCLs are from Drinking Water Regulations, 20 NMAC 7.1.

${ }^{c}$ NMED = New Mexico Environment Department.

d State of New Mexico groundwater standards are from New Mexico Water Quality Control Commission Regulations, Ground and Surface Water Protection, 20 NMAC 6.2.

$\mathrm{NF}=$ Nonfiltered.

$-=$ Not available or not applicable.

${ }^{g} \mathrm{~F}=$ Filtered. 
Table A-17

Regional Well R-7 Screen 1 Third Round Sample Results: Data Summary for Radionuclides

\begin{tabular}{|c|c|c|c|c|c|c|c|c|c|c|}
\hline Analyte & Screen & $\begin{array}{c}\text { Depth } \\
\text { (ft) }\end{array}$ & $\begin{array}{l}\text { Collection } \\
\text { Date }\end{array}$ & $\begin{array}{c}\text { Field } \\
\text { Preparation }\end{array}$ & $\begin{array}{l}\text { Number of } \\
\text { Analyses }\end{array}$ & $\begin{array}{l}\text { Number of } \\
\text { Detects }\end{array}$ & $\begin{array}{l}\text { Detected } \\
\text { Value } \\
\text { (pCi/L) }\end{array}$ & $\begin{array}{c}\text { Nondetected } \\
\text { Value } \\
\text { (pCi/L) }\end{array}$ & $\begin{array}{c}\text { Drinking } \\
\text { Water } M C L^{b} \\
(p C i / L)\end{array}$ & $\begin{array}{c}\text { Frequency of } \\
\text { Detects > Drinking } \\
\text { Water MCL }\end{array}$ \\
\hline Americium-241 & 1 & 378 & $11 / 19 / 01$ & $\mathrm{~F}^{\mathrm{c}}$ & 1 & 0 & $-{ }^{d}$ & {$[0.0087]$} & $15^{\mathrm{e}}$ & $0 / 1$ \\
\hline Americium-241 & 1 & 378 & $11 / 19 / 01$ & $\mathrm{NF}^{\mathrm{f}}$ & 1 & 0 & - & [0.00793] & - & - \\
\hline Cesium-134 & 1 & 378 & $11 / 19 / 01$ & $\mathrm{~F}$ & 1 & 0 & - & {$[-0.379]$} & - & - \\
\hline Cesium-134 & 1 & 378 & $11 / 19 / 01$ & $\mathrm{NF}$ & 1 & 0 & - & [0.203] & - & - \\
\hline Cesium-137 & 1 & 378 & $11 / 19 / 01$ & $\mathrm{~F}$ & 1 & 0 & - & [1.29] & - & - \\
\hline Cesium-137 & 1 & 378 & $11 / 19 / 01$ & $\mathrm{NF}$ & 1 & 0 & - & {$[0.471]$} & - & - \\
\hline Cobalt-60 & 1 & 378 & $11 / 19 / 01$ & $\mathrm{~F}$ & 1 & 0 & - & {$[-0.827]$} & - & - \\
\hline Cobalt-60 & 1 & 378 & $11 / 19 / 01$ & $\mathrm{NF}$ & 1 & 0 & - & {$[-0.736]$} & - & - \\
\hline Europium-152 & 1 & 378 & $11 / 19 / 01$ & $\mathrm{~F}$ & 1 & 0 & - & {$[-0.804]$} & - & - \\
\hline Europium-152 & 1 & 378 & $11 / 19 / 01$ & $\mathrm{NF}$ & 1 & 0 & - & {$[-0.75]$} & - & - \\
\hline Gross Alpha Radiation & 1 & 378 & $11 / 19 / 01$ & $\mathrm{NF}$ & 1 & 0 & - & {$[0.456]$} & - & - \\
\hline Gross Beta Radiation & 1 & 378 & $11 / 19 / 01$ & $\mathrm{NF}$ & 1 & 1 & 2 & - & - & - \\
\hline Plutonium-238 & 1 & 378 & $11 / 19 / 01$ & $\mathrm{~F}$ & 1 & 0 & - & [0] & $15^{\mathrm{e}}$ & $0 / 1$ \\
\hline Plutonium-238 & 1 & 378 & $11 / 19 / 01$ & NF & 1 & 0 & - & {$[-0.0045]$} & - & - \\
\hline Plutonium-239 & 1 & 378 & $11 / 19 / 01$ & $\mathrm{~F}$ & 1 & 0 & - & {$[-0.00214]$} & $15^{\mathrm{e}}$ & $0 / 1$ \\
\hline Plutonium-239 & 1 & 378 & $11 / 19 / 01$ & $\mathrm{NF}$ & 1 & 0 & - & {$[0.0158]$} & - & - \\
\hline Ruthenium-106 & 1 & 378 & $11 / 19 / 01$ & $\mathrm{NF}$ & 1 & 0 & - & {$[-5.85]$} & - & - \\
\hline Ruthenium-106 & 1 & 378 & $11 / 19 / 01$ & $\mathrm{NF}$ & 1 & 0 & - & {$[-5.85]$} & - & - \\
\hline Strontium-90 & 1 & 378 & $11 / 19 / 01$ & $\mathrm{~F}$ & 1 & 0 & - & {$[-0.0037]$} & 8 & $0 / 1$ \\
\hline Strontium-90 & 1 & 378 & $11 / 19 / 01$ & $\mathrm{NF}$ & 1 & 0 & - & {$[-0.148]$} & - & - \\
\hline Technetium-99 & 1 & 378 & $11 / 19 / 01$ & $\mathrm{NF}$ & 1 & 0 & - & {$[2.47]$} & - & - \\
\hline Tritium & 1 & 378 & $11 / 19 / 01$ & $\mathrm{NF}$ & 1 & 1 & 2.74 & - & 20000 & $0 / 1$ \\
\hline Uranium-234 & 1 & 378 & $11 / 19 / 01$ & $\mathrm{~F}$ & 1 & 1 & 0.05 & - & - & - \\
\hline Uranium-234 & 1 & 378 & $11 / 19 / 01$ & $\mathrm{NF}$ & 1 & 1 & 0.0493 & - & - & - \\
\hline Uranium-235 & 1 & 378 & $11 / 19 / 01$ & $\mathrm{~F}$ & 1 & 0 & - & {$[0.0046]$} & - & - \\
\hline Uranium-235 & 1 & 378 & 11/19/01 & NF & 1 & 0 & - & [0.0043] & - & - \\
\hline
\end{tabular}




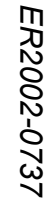

Table A-17 (continued)

\begin{tabular}{|c|c|c|c|c|c|c|c|c|c|c|}
\hline Analyte & Screen & $\begin{array}{l}\text { Depth } \\
\text { (ft) }\end{array}$ & $\begin{array}{l}\text { Collection } \\
\text { Date }\end{array}$ & $\begin{array}{c}\text { Field } \\
\text { Preparation }\end{array}$ & $\begin{array}{l}\text { Number of } \\
\text { Analyses }\end{array}$ & $\begin{array}{c}\text { Number of } \\
\text { Detects }\end{array}$ & $\begin{array}{l}\text { Detected } \\
\text { Value } \\
\text { (pCi/L) }\end{array}$ & $\begin{array}{l}\text { Nondetected } \\
\text { Value } \\
\text { (pCi/L) }\end{array}$ & $\begin{array}{c}\text { Drinking } \\
\text { Water MCL }{ }^{\mathrm{b}} \\
\text { (pCi/L) }\end{array}$ & $\begin{array}{c}\text { Frequency of } \\
\text { Detects }>\text { Drinking } \\
\text { Water MCL }\end{array}$ \\
\hline Uranium-238 & 1 & 378 & $11 / 19 / 01$ & $\mathrm{~F}$ & 1 & 0 & - & {$[0.0113]$} & - & - \\
\hline Uranium-238 & 1 & 378 & 11/19/01 & $\mathrm{NF}$ & 1 & 0 & - & {$[0.0129]$} & - & - \\
\hline
\end{tabular}

The static water level for the regional aquifer at R-7 was $902.8 \mathrm{ft}$ when the well was drilled

${ }^{\mathrm{b}} \mathrm{MCL}=$ Maximum contaminant level. US Environmental Protection Agency (EPA) MCLs are from National Primary Drinking Water Regulations, 40 CFR Part 141. US EPA secondary MCLs are from National Secondary Drinking Water Regulations, 40 CFR Part 143. State of New Mexico MCLs are from Drinking Water Regulations, 20 NMAC 7.1.

${ }^{\mathrm{c}} \mathrm{F}=$ Filtered

${ }^{d}-=$ Not available or not applicable

Based on an MCL of $15 \mathrm{pCi} / \mathrm{L}$ (including radium-226, but excluding radon and uranium).

${ }^{\mathrm{f}} \mathrm{NF}=$ Nonfiltered. 
Table A-18

Regional Well R-7 Screen 3 Third Round Sample Results: Data Summary for Radionuclides

\begin{tabular}{|c|c|c|c|c|c|c|c|c|c|c|}
\hline Analyte & Screen & $\begin{array}{c}\text { Depth } \\
\text { (ft) }\end{array}$ & $\begin{array}{l}\text { Collection } \\
\text { Date }\end{array}$ & $\begin{array}{c}\text { Field } \\
\text { Preparation }\end{array}$ & $\begin{array}{l}\text { Number of } \\
\text { Analyses }\end{array}$ & $\begin{array}{l}\text { Number of } \\
\text { Detects }\end{array}$ & $\begin{array}{l}\text { Detected } \\
\text { Value } \\
\text { (pCi/L) }\end{array}$ & $\begin{array}{c}\text { Nondetected } \\
\text { Value } \\
\text { (pCi/L) }\end{array}$ & $\begin{array}{c}\text { Drinking } \\
\text { Water } M C L^{b} \\
(p C i / L)\end{array}$ & $\begin{array}{c}\text { Frequency of } \\
\text { Detects > Drinking } \\
\text { Water MCL }\end{array}$ \\
\hline Americium-241 & 3 & 915 & $11 / 27 / 01$ & $\mathrm{~F}^{\mathrm{c}}$ & 1 & 0 & $-{ }^{d}$ & [0.0118] & $15^{\mathrm{e}}$ & $0 / 1$ \\
\hline Americium-241 & 3 & 915 & $11 / 27 / 01$ & $\mathrm{NF}^{\mathrm{f}}$ & 1 & 0 & - & {$[0.0111]$} & - & - \\
\hline Cesium-134 & 3 & 915 & $11 / 27 / 01$ & $\mathrm{~F}$ & 1 & 0 & - & {$[-0.935]$} & - & - \\
\hline Cesium-134 & 3 & 915 & $11 / 27 / 01$ & $\mathrm{NF}$ & 1 & 0 & - & [0.465] & - & - \\
\hline Cesium-137 & 3 & 915 & $11 / 27 / 01$ & $\mathrm{~F}$ & 1 & 0 & - & [0.414] & - & - \\
\hline Cesium-137 & 3 & 915 & $11 / 27 / 01$ & $\mathrm{NF}$ & 1 & 0 & - & {$[0.608]$} & - & - \\
\hline Cobalt-60 & 3 & 915 & $11 / 27 / 01$ & $\mathrm{~F}$ & 1 & 0 & - & {$[-0.275]$} & - & - \\
\hline Cobalt-60 & 3 & 915 & $11 / 27 / 01$ & $\mathrm{NF}$ & 1 & 0 & - & {$[-0.0653]$} & - & - \\
\hline Europium-152 & 3 & 915 & $11 / 27 / 01$ & $\mathrm{~F}$ & 1 & 0 & - & {$[-0.291]$} & - & - \\
\hline Europium-152 & 3 & 915 & $11 / 27 / 01$ & $\mathrm{NF}$ & 1 & 0 & - & {$[-1.08]$} & - & - \\
\hline Gross Alpha Radiation & 3 & 915 & $11 / 27 / 01$ & $\mathrm{NF}$ & 1 & 1 & 2.32 & - & - & - \\
\hline Gross Beta Radiation & 3 & 915 & $11 / 27 / 01$ & $\mathrm{NF}$ & 1 & 1 & 3.25 & - & - & - \\
\hline Plutonium-238 & 3 & 915 & $11 / 27 / 01$ & $\mathrm{~F}$ & 1 & 0 & - & {$[-0.00448]$} & $15^{\mathrm{e}}$ & $0 / 1$ \\
\hline Plutonium-238 & 3 & 915 & $11 / 27 / 01$ & $\mathrm{NF}$ & 1 & 0 & - & [0] & - & - \\
\hline Plutonium-239 & 3 & 915 & $11 / 27 / 01$ & $\mathrm{~F}$ & 1 & 0 & - & {$[0.00447]$} & $15^{\mathrm{e}}$ & $0 / 1$ \\
\hline Plutonium-239 & 3 & 915 & $11 / 27 / 01$ & $\mathrm{NF}$ & 1 & 0 & - & {$[0.00336]$} & - & - \\
\hline Ruthenium-106 & 3 & 915 & $11 / 27 / 01$ & $\mathrm{~F}$ & 1 & 0 & - & {$[2.16]$} & - & - \\
\hline Ruthenium-106 & 3 & 915 & $11 / 27 / 01$ & $\mathrm{NF}$ & 1 & 0 & - & {$[-0.923]$} & - & - \\
\hline Strontium-90 & 3 & 915 & $11 / 27 / 01$ & $\mathrm{~F}$ & 1 & 0 & - & [0.0329] & 8 & $0 / 1$ \\
\hline Strontium-90 & 3 & 915 & $11 / 27 / 01$ & $\mathrm{NF}$ & 1 & 0 & - & {$[-0.0204]$} & - & - \\
\hline Technetium-99 & 3 & 915 & $11 / 27 / 01$ & $\mathrm{NF}$ & 1 & 0 & - & {$[0.457]$} & - & - \\
\hline Tritium & 3 & 915 & $11 / 27 / 01$ & $\mathrm{NF}$ & 1 & 1 & 1.72 & - & 20000 & $0 / 1$ \\
\hline Uranium-234 & 3 & 915 & $11 / 27 / 01$ & $\mathrm{~F}$ & 1 & 1 & 0.0602 & - & - & - \\
\hline Uranium-234 & 3 & 915 & $11 / 27 / 01$ & $\mathrm{NF}$ & 1 & 1 & 0.0691 & - & - & - \\
\hline Uranium-235 & 3 & 915 & $11 / 27 / 01$ & $\mathrm{~F}$ & 1 & 0 & - & {$[0.00787]$} & - & - \\
\hline Uranium-235 & 3 & 915 & $11 / 27 / 01$ & NF & 1 & 0 & - & {$[0.0077]$} & - & - \\
\hline
\end{tabular}




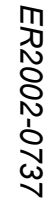

Table A-18 (continued)

\begin{tabular}{|c|c|c|c|c|c|c|c|c|c|c|}
\hline Analyte & Screen & $\begin{array}{l}\text { Depth } \\
\text { (ft) }\end{array}$ & $\begin{array}{l}\text { Collection } \\
\text { Date }\end{array}$ & $\begin{array}{c}\text { Field } \\
\text { Preparation }\end{array}$ & $\begin{array}{l}\text { Number of } \\
\text { Analyses }\end{array}$ & $\begin{array}{l}\text { Number of } \\
\text { Detects }\end{array}$ & $\begin{array}{l}\text { Detected } \\
\text { Value } \\
\text { (pCi/L) }\end{array}$ & $\begin{array}{l}\text { Nondetected } \\
\text { Value } \\
\text { (pCi/L) }\end{array}$ & $\begin{array}{c}\text { Drinking } \\
\text { Water MCL }{ }^{\mathrm{b}} \\
\text { (pCi/L) }\end{array}$ & $\begin{array}{c}\text { Frequency of } \\
\text { Detects }>\text { Drinking } \\
\text { Water MCL }\end{array}$ \\
\hline Uranium-238 & 3 & 915 & $11 / 27 / 01$ & $\mathrm{~F}$ & 1 & 0 & - & {$[0.0262]$} & - & - \\
\hline Uranium-238 & 3 & 915 & $11 / 27 / 01$ & $\mathrm{NF}$ & 1 & 1 & 0.0358 & - & - & - \\
\hline
\end{tabular}

The static water level for the regional aquifer at R-7 was $902.8 \mathrm{ft}$ when the well was drilled

${ }^{\mathrm{b}} \mathrm{MCL}=$ Maximum contaminant level. US Environmental Protection Agency (EPA) MCLs are from National Primary Drinking Water Regulations, 40 CFR Part 141. US EPA secondary MCLs are from National Secondary Drinking Water Regulations, 40 CFR Part 143. State of New Mexico MCLs are from Drinking Water Regulations, 20 NMAC 7.1.

${ }^{\mathrm{c}} \mathrm{F}=$ Filtered

${ }^{d}-=$ Not available or not applicable

Based on an MCL of $15 \mathrm{pCi} / \mathrm{L}$ (including radium-226, but excluding radon and uranium).

${ }^{\mathrm{f}} \mathrm{NF}=$ Nonfiltered. 
Table A-19

Regional Well R-7 Screen 1 Fourth Round Sample Results: Data Summary for Inorganic Chemicals

\begin{tabular}{|c|c|c|c|c|c|c|c|c|c|c|c|c|}
\hline $\begin{array}{l}\text { Parameter } \\
\text { and } \\
\text { Analyte }\end{array}$ & Screen & $\begin{array}{l}\text { Depth } \\
(\mathrm{ft})^{\mathrm{a}}\end{array}$ & $\begin{array}{l}\text { Collection } \\
\text { Date }\end{array}$ & $\begin{array}{c}\text { Field } \\
\text { Preparation }\end{array}$ & $\begin{array}{l}\text { Number } \\
\text { of } \\
\text { Analyses }\end{array}$ & $\begin{array}{l}\text { Number } \\
\text { of } \\
\text { Detects }\end{array}$ & $\begin{array}{l}\text { Detected } \\
\text { Value } \\
\text { ( } \mu \mathrm{g} / \mathrm{L})\end{array}$ & $\begin{array}{c}\text { Non- } \\
\text { detected } \\
\text { Value } \\
(\mu \mathrm{g} / \mathrm{L})\end{array}$ & $\begin{array}{l}\text { Drinking } \\
\text { Water } \\
M C L^{b} \\
(\mu \mathrm{g} / \mathrm{L})\end{array}$ & $\begin{array}{l}\text { Frequency } \\
\text { of Detects } \\
\text { > Drinking } \\
\text { Water MCL }\end{array}$ & $\begin{array}{c}\text { NMED }^{c} \\
\text { Groundwater } \\
\text { Standard }^{\mathrm{d}} \\
(\mu \mathrm{g} / \mathrm{L})\end{array}$ & $\begin{array}{l}\text { Frequency of } \\
\text { Detects > NMED } \\
\text { Groundwater } \\
\text { Standard }\end{array}$ \\
\hline \multicolumn{13}{|l|}{ Field Parameter } \\
\hline $\begin{array}{l}\text { Field Alkalinity (total } \\
\text { as } \mathrm{CaCO}_{3} \text { ) }\end{array}$ & 1 & 378 & 02/19/02 & $\mathrm{NF}^{\mathrm{e}}$ & 1 & 1 & 46000 & $-^{f}$ & - & - & - & - \\
\hline Dissolved Oxygen & 1 & 378 & 02/19/02 & NF & 1 & 1 & 6100 & - & - & - & - & - \\
\hline $\mathrm{pH}$ & 1 & 378 & 02/19/02 & NF & 1 & 1 & 7.43 & - & $>6 \&<9$ & $0 / 1$ & $>6 \&<9$ & $0 / 1$ \\
\hline $\begin{array}{l}\text { Specific Conductance } \\
(\mu \mathrm{S} / \mathrm{cm})\end{array}$ & 1 & 378 & 02/19/02 & NF & 1 & 1 & 97 & - & - & $0 / 1$ & - & $0 / 1$ \\
\hline Temperature $\left({ }^{\circ} \mathrm{C}\right)$ & 1 & 378 & 02/19/02 & NF & 1 & 1 & 10.0 & - & - & $0 / 1$ & - & $0 / 1$ \\
\hline Turbidity (NTUg) & 1 & 378 & 02/19/02 & NF & 1 & 1 & 0.56 & - & - & $0 / 1$ & - & $0 / 1$ \\
\hline \multicolumn{13}{|l|}{ Analyte } \\
\hline $\begin{array}{l}\text { Lab Alkalinity (total as } \\
\mathrm{CaCO}_{3} \text { ) }\end{array}$ & 1 & 378 & $02 / 19 / 02$ & $\mathrm{~F}^{\mathrm{h}}$ & 1 & 1 & 20700 & - & - & - & - & - \\
\hline Aluminum & 1 & 378 & 02/19/02 & $\mathrm{F}$ & 1 & 0 & - & [50] & 50 & $0 / 1$ & 5000 & $0 / 1$ \\
\hline Aluminum & 1 & 378 & 02/19/02 & NF & 1 & 0 & - & [50] & - & - & - & - \\
\hline Ammonia (as N) & 1 & 378 & 02/19/02 & $\mathrm{F}$ & 1 & 0 & - & [50] & - & - & - & - \\
\hline Antimony & 1 & 378 & 02/19/02 & $\mathrm{F}$ & 1 & 1 & 0.21 & - & 6 & $0 / 2$ & - & - \\
\hline Antimony & 1 & 378 & $02 / 19 / 02$ & NF & 1 & 1 & & {$[0.2]$} & - & - & - & - \\
\hline Arsenic & 1 & 378 & 02/19/02 & $\mathrm{F}$ & 1 & 0 & - & [5] & 50 & $0 / 1$ & 100 & $0 / 1$ \\
\hline Arsenic & 1 & 378 & 02/19/02 & NF & 1 & 0 & - & [5] & - & - & - & - \\
\hline Barium & 1 & 378 & 02/19/02 & $\mathrm{F}$ & 1 & 1 & 56 & - & 2000 & $0 / 1$ & 1000 & $0 / 1$ \\
\hline Barium & 1 & 378 & 02/19/02 & NF & 1 & 1 & 54.8 & - & - & - & - & - \\
\hline Beryllium & 1 & 378 & 02/19/02 & $\mathrm{F}$ & 1 & 0 & - & {$[0.2]$} & 4 & $0 / 2$ & - & - \\
\hline Beryllium & 1 & 378 & $02 / 19 / 02$ & NF & 1 & 0 & - & {$[0.2]$} & - & - & - & - \\
\hline Boron & 1 & 378 & 02/19/02 & $\mathrm{F}$ & 1 & 0 & - & [50] & - & - & 750 & $0 / 1$ \\
\hline Boron & 1 & 378 & 02/19/02 & NF & 1 & 0 & - & [50] & - & - & - & - \\
\hline Bromide & 1 & 378 & 02/19/02 & $\mathrm{F}$ & 1 & 0 & - & [200] & - & - & - & - \\
\hline Cadmium & 1 & 378 & 02/19/02 & $\mathrm{F}$ & 1 & 0 & - & {$[1]$} & 5 & $0 / 2$ & 10 & $0 / 2$ \\
\hline
\end{tabular}


Table A-19 (continued)

\begin{tabular}{|c|c|c|c|c|c|c|c|c|c|c|c|c|}
\hline $\begin{array}{l}\text { Parameter } \\
\text { and } \\
\text { Analyte }\end{array}$ & Screen & $\begin{array}{l}\text { Depth } \\
(\mathrm{ft})^{\mathrm{a}}\end{array}$ & $\begin{array}{l}\text { Collection } \\
\text { Date }\end{array}$ & $\begin{array}{c}\text { Field } \\
\text { Preparation }\end{array}$ & $\begin{array}{l}\text { Number } \\
\text { of } \\
\text { Analyses }\end{array}$ & $\begin{array}{c}\text { Number } \\
\text { of } \\
\text { Detects }\end{array}$ & $\begin{array}{c}\text { Detected } \\
\text { Value } \\
\text { ( } \mu \mathrm{g} / \mathrm{L})\end{array}$ & $\begin{array}{l}\text { Non- } \\
\text { detected } \\
\text { Value } \\
(\mu \mathrm{g} / \mathrm{L})\end{array}$ & $\begin{array}{l}\text { Drinking } \\
\text { Water } \\
\text { MCL }^{\mathrm{b}} \\
(\mu \mathrm{g} / \mathrm{L})\end{array}$ & $\begin{array}{l}\text { Frequency } \\
\text { of Detects } \\
>\text { Drinking } \\
\text { Water MCL }\end{array}$ & $\begin{array}{c}\text { NMED }^{c} \\
\text { Groundwater } \\
\text { Standard }^{\mathrm{d}} \\
(\mu \mathrm{g} / \mathrm{L})\end{array}$ & $\begin{array}{c}\text { Frequency of } \\
\text { Detects }>\text { NMED } \\
\text { Groundwater } \\
\text { Standard }\end{array}$ \\
\hline Cadmium & 1 & 378 & $02 / 19 / 02$ & NF & 1 & 0 & - & [1] & - & - & - & - \\
\hline Calcium & 1 & 378 & 02/19/02 & $\mathrm{F}$ & 1 & 1 & 7150 & - & - & - & - & - \\
\hline Calcium & 1 & 378 & 02/19/02 & NF & 1 & 1 & 6870 & - & - & - & - & - \\
\hline Chloride & 1 & 378 & 02/19/02 & $\mathrm{F}$ & 1 & 1 & 1560 & - & 250000 & $0 / 1$ & 250000 & $0 / 1$ \\
\hline Chromium & 1 & 378 & 02/19/02 & $\mathrm{F}$ & 1 & 1 & 2.91 & - & 100 & $0 / 1$ & 50 & $0 / 1$ \\
\hline Chromium & 1 & 378 & 02/19/02 & NF & 1 & 1 & 48.8 & - & - & - & - & - \\
\hline Cobalt & 1 & 378 & 02/19/02 & $\mathrm{F}$ & 1 & 0 & - & {$[5]$} & - & - & 50 & $0 / 1$ \\
\hline Cobalt & 1 & 378 & 02/19/02 & NF & 1 & 0 & - & [5] & - & - & - & - \\
\hline Copper & 1 & 378 & 02/19/02 & $\mathrm{F}$ & 1 & 0 & - & [5] & 1300 & $0 / 1$ & 1000 & $0 / 1$ \\
\hline Copper & 1 & 378 & 02/19/02 & NF & 1 & 0 & - & [5] & - & - & - & - \\
\hline Cyanide (total) & 1 & 378 & 02/19/02 & NF & 1 & 0 & - & [5] & - & - & - & - \\
\hline Fluoride & 1 & 378 & 02/19/02 & $\mathrm{F}$ & 1 & 1 & 76 & - & 4000 & $0 / 1$ & 1600 & $0 / 1$ \\
\hline Iron & 1 & 378 & 02/19/02 & $\mathrm{F}$ & 1 & 0 & - & [50] & 300 & $0 / 1$ & 1000 & $0 / 1$ \\
\hline Iron & 1 & 378 & 02/19/02 & NF & 1 & 1 & 184 & 184 & - & - & - & - \\
\hline Lead & 1 & 378 & $02 / 19 / 02$ & $\mathrm{~F}$ & 1 & 0 & - & [2] & 15 & $0 / 2$ & 50 & $0 / 2$ \\
\hline Lead & 1 & 378 & 02/19/02 & NF & 1 & 1 & - & [2] & - & - & - & - \\
\hline Magnesium & 1 & 378 & 02/19/02 & $\mathrm{F}$ & 1 & 1 & 1430 & - & - & - & - & - \\
\hline Magnesium & 1 & 378 & 02/19/02 & NF & 1 & 1 & 1380 & - & - & - & - & - \\
\hline Manganese & 1 & 378 & $02 / 19 / 02$ & $\mathrm{~F}$ & 1 & 1 & 50.1 & - & 50 & $1 / 1$ & 200 & $0 / 1$ \\
\hline Manganese & 1 & 378 & 02/19/02 & NF & 1 & 1 & 51.1 & - & - & - & - & - \\
\hline Mercury & 1 & 378 & $02 / 19 / 02$ & $\mathrm{~F}$ & 1 & 0 & - & {$[0.2]$} & 2 & $0 / 1$ & - & - \\
\hline Mercury & 1 & 378 & 02/19/02 & NF & 1 & 0 & - & {$[0.2]$} & - & - & 2 & $0 / 1$ \\
\hline Molybdenum & 1 & 378 & 02/19/02 & $\mathrm{F}$ & 1 & 1 & 1.65 & 1.65 & - & - & - & - \\
\hline Molybdenum & 1 & 378 & $02 / 19 / 02$ & NF & 1 & 1 & 3 & - & - & - & - & - \\
\hline Nickel & 1 & 378 & 02/19/02 & $\mathrm{F}$ & 1 & 0 & - & {$[5]$} & 100 & $0 / 1$ & 200 & $0 / 1$ \\
\hline Nickel & 1 & 378 & 02/19/02 & NF & 1 & 1 & 28.4 & - & - & - & - & - \\
\hline Nitrate + Nitrite (as N) & 1 & 378 & 02/19/02 & $\mathrm{F}$ & 1 & 1 & 270 & - & 10000 & $0 / 1$ & - & - \\
\hline
\end{tabular}


Table A-19 (continued)

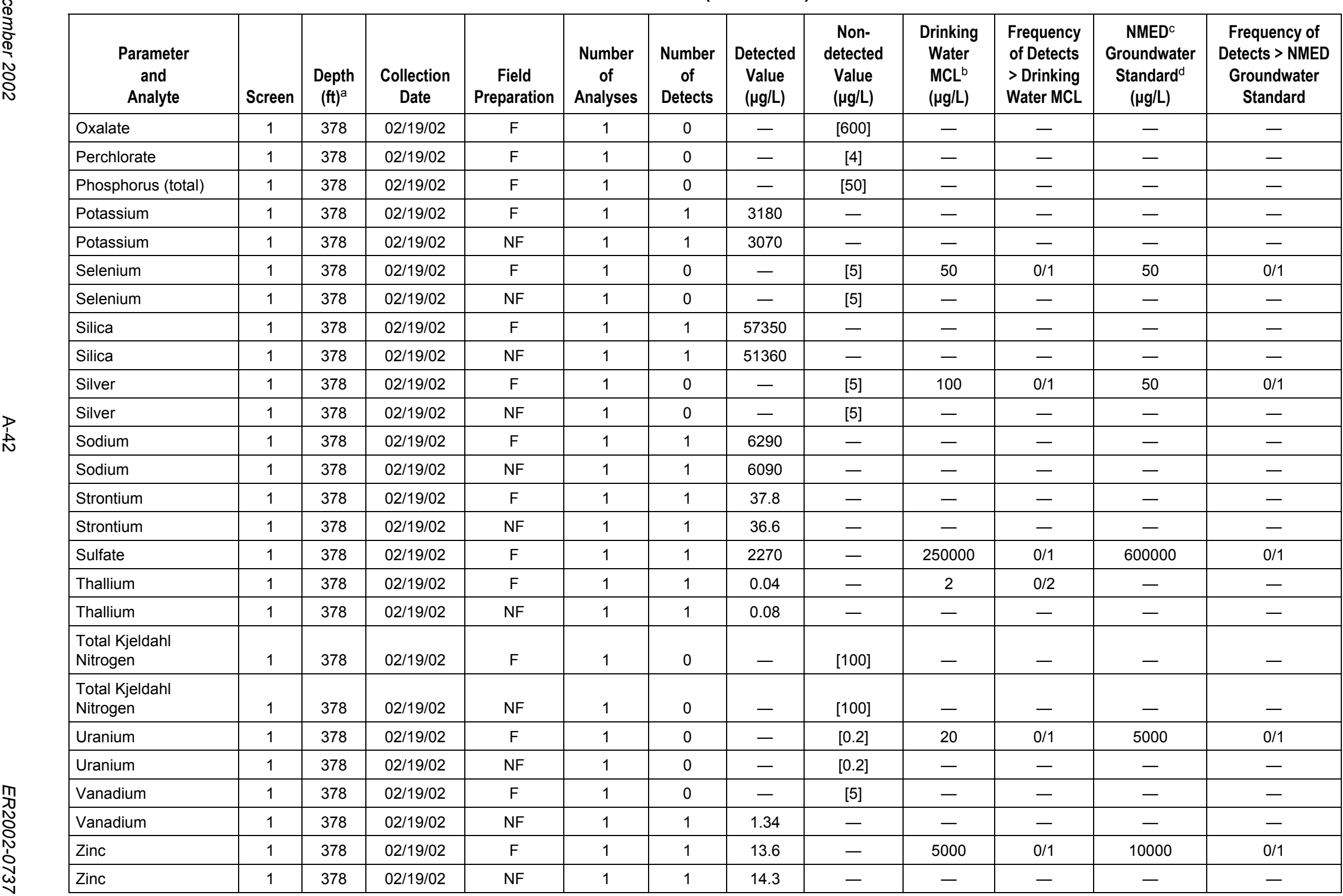


Table A-19 (continued)

\begin{tabular}{|c|c|c|c|c|c|c|c|c|c|c|c|c|}
\hline $\begin{array}{l}\text { Parameter } \\
\text { and } \\
\text { Analyte }\end{array}$ & Screen & $\begin{array}{l}\text { Depth } \\
\text { (ft) }\end{array}$ & $\begin{array}{l}\text { Collection } \\
\text { Date }\end{array}$ & $\begin{array}{c}\text { Field } \\
\text { Preparation }\end{array}$ & $\begin{array}{l}\text { Number } \\
\text { of } \\
\text { Analyses }\end{array}$ & $\begin{array}{l}\text { Number } \\
\text { of } \\
\text { Detects }\end{array}$ & $\begin{array}{l}\text { Detected } \\
\text { Value } \\
(\mu \mathrm{g} / \mathrm{L})\end{array}$ & $\begin{array}{l}\text { Non- } \\
\text { detected } \\
\text { Value } \\
(\mu \mathrm{g} / \mathrm{L})\end{array}$ & $\begin{array}{l}\text { Drinking } \\
\text { Water } \\
M C L^{b} \\
(\mu \mathrm{g} / \mathrm{L})\end{array}$ & $\begin{array}{l}\text { Frequency } \\
\text { of Detects } \\
>\text { Drinking } \\
\text { Water MCL }\end{array}$ & $\begin{array}{c}\text { NMED }^{c} \\
\text { Groundwater } \\
\text { Standard } \\
(\mu \mathrm{g} / \mathrm{L})\end{array}$ & $\begin{array}{c}\text { Frequency of } \\
\text { Detects }>\text { NMED } \\
\text { Groundwater } \\
\text { Standard }\end{array}$ \\
\hline \multicolumn{13}{|c|}{ Stable Isotope (\%) } \\
\hline$\delta D$ & 1 & 378 & 02/19/02 & $\mathrm{NF}$ & 1 & 1 & -80 & - & - & - & - & - \\
\hline$\delta^{15} \mathrm{~N}\left(\mathrm{NO}_{3}\right)$ & 1 & 378 & 02/19/02 & $\mathrm{NF}$ & 1 & 1 & ISVi & - & - & - & - & - \\
\hline$\delta^{18} \mathrm{O}$ & 1 & 378 & $02 / 19 / 02$ & $\mathrm{NF}$ & 1 & 1 & -11.5 & - & - & - & - & - \\
\hline
\end{tabular}

a The static water level for the regional aquifer at R-7 was $902.8 \mathrm{ft}$ when the well was drilled.

${ }^{\mathrm{b}} \mathrm{MCL}=$ Maximum contaminant level. US Environmental Protection Agency (EPA) MCLs are from National Primary Drinking Water Regulations, 40 CFR Part 141. US EPA secondary MCLs are from National Secondary Drinking Water Regulations, 40 CFR Part 143. State of New Mexico MCLs are from Drinking Water Regulations, 20 NMAC 7.1.

${ }^{c}$ NMED = New Mexico Environment Department.

d State of New Mexico groundwater standards are from New Mexico Water Quality Control Commission Regulations, Ground and Surface Water Protection, 20 NMAC 6.2.

$\mathrm{NF}=$ Nonfiltered

f $-=$ Not available or not applicable

${ }^{g}$ NTU = Nephelometric turbidity unit.

$\mathrm{h} F=$ Filtered

ISV $=$ Insufficient sample volume for analysis. 
Table A-20

Regional Well R-7 Screen 3 Fourth Round Sample Results: Data Summary for Inorganic Chemicals

\begin{tabular}{|c|c|c|c|c|c|c|c|c|c|c|c|c|}
\hline $\begin{array}{l}\text { Parameter } \\
\text { and } \\
\text { Analyte }\end{array}$ & Screen & $\begin{array}{l}\text { Depth } \\
(\mathrm{ft})^{\mathrm{a}}\end{array}$ & $\begin{array}{l}\text { Collection } \\
\text { Date }\end{array}$ & $\begin{array}{c}\text { Field } \\
\text { Preparation }\end{array}$ & $\begin{array}{l}\text { Number } \\
\text { of } \\
\text { Analyses }\end{array}$ & $\begin{array}{l}\text { Number } \\
\text { of } \\
\text { Detects }\end{array}$ & $\begin{array}{l}\text { Detected } \\
\text { Value } \\
\text { ( } \mu \mathrm{g} / \mathrm{L})\end{array}$ & $\begin{array}{c}\text { Non- } \\
\text { detected } \\
\text { Value } \\
(\mu \mathrm{g} / \mathrm{L})\end{array}$ & $\begin{array}{l}\text { Drinking } \\
\text { Water } \\
M C L^{b} \\
(\mu \mathrm{g} / \mathrm{L})\end{array}$ & $\begin{array}{l}\text { Frequency } \\
\text { of Detects } \\
\text { > Drinking } \\
\text { Water MCL }\end{array}$ & $\begin{array}{c}\text { NMED }^{c} \\
\text { Groundwater } \\
\text { Standard }^{\mathrm{d}} \\
(\mu \mathrm{g} / \mathrm{L})\end{array}$ & $\begin{array}{l}\text { Frequency of } \\
\text { Detects > NMED } \\
\text { Groundwater } \\
\text { Standard }\end{array}$ \\
\hline \multicolumn{13}{|l|}{ Field Parameter } \\
\hline $\begin{array}{l}\text { Field Alkalinity (total } \\
\text { as } \mathrm{CaCO}_{3} \text { ) }\end{array}$ & 3 & 915 & $02 / 21 / 02$ & $\mathrm{NF}^{\mathrm{e}}$ & 1 & 1 & 114000 & $-^{f}$ & - & - & - & - \\
\hline Dissolved Oxygen & 3 & 915 & $02 / 21 / 02$ & NF & 1 & 1 & 1400 & - & - & - & - & - \\
\hline $\mathrm{pH}$ & 3 & 915 & $02 / 21 / 02$ & NF & 1 & 1 & 7.28 & - & $>6 \&<9$ & $0 / 1$ & $>6 \&<9$ & $0 / 1$ \\
\hline $\begin{array}{l}\text { Specific Conductance } \\
(\mu \mathrm{S} / \mathrm{cm})\end{array}$ & 3 & 915 & $02 / 21 / 02$ & NF & 1 & 1 & 187 & - & - & $0 / 1$ & - & $0 / 1$ \\
\hline Temperature $\left({ }^{\circ} \mathrm{C}\right)$ & 3 & 915 & $02 / 21 / 02$ & NF & 1 & 1 & 13.3 & - & - & $0 / 1$ & - & $0 / 1$ \\
\hline Turbidity (NTUg) & 3 & 915 & $02 / 21 / 02$ & NF & 1 & 1 & 2.79 & - & - & $0 / 1$ & - & $0 / 1$ \\
\hline \multicolumn{13}{|l|}{ Analyte } \\
\hline $\begin{array}{l}\text { Lab Alkalinity (total as } \\
\mathrm{CaCO}_{3} \text { ) }\end{array}$ & 3 & 915 & $02 / 21 / 02$ & $\mathrm{~F}^{\mathrm{h}}$ & 1 & 1 & 54200 & - & - & - & - & - \\
\hline Aluminum & 3 & 915 & $02 / 21 / 02$ & $\mathrm{~F}$ & 1 & 0 & - & [50] & 50 & $0 / 1$ & 5000 & $0 / 1$ \\
\hline Aluminum & 3 & 915 & $02 / 21 / 02$ & NF & 1 & 0 & - & [50] & - & - & - & - \\
\hline Ammonia (as N) & 3 & 915 & 02/21/02 & $\mathrm{F}$ & 1 & 1 & 380 & - & - & - & - & - \\
\hline Antimony & 3 & 915 & 02/21/02 & $\mathrm{F}$ & 1 & 0 & - & {$[0.73]$} & 6 & $0 / 2$ & - & - \\
\hline Antimony & 3 & 915 & 02/21/02 & NF & 1 & 0 & - & {$[0.24]$} & - & - & - & - \\
\hline Arsenic & 3 & 915 & 02/21/02 & $\mathrm{F}$ & 1 & 1 & 5.79 & - & 50 & $0 / 1$ & 100 & $0 / 1$ \\
\hline Arsenic & 3 & 915 & $02 / 21 / 02$ & NF & 1 & 1 & 8.12 & - & - & - & - & - \\
\hline Barium & 3 & 915 & $02 / 21 / 02$ & $\mathrm{~F}$ & 1 & 1 & 172 & - & 2000 & $0 / 1$ & 1000 & $0 / 1$ \\
\hline Barium & 3 & 915 & 02/21/02 & NF & 1 & 1 & 167 & - & - & - & - & - \\
\hline Beryllium & 3 & 915 & $02 / 21 / 02$ & $\mathrm{~F}$ & 1 & 1 & 0.05 & - & 4 & $0 / 2$ & - & - \\
\hline Beryllium & 3 & 915 & $02 / 21 / 02$ & NF & 1 & 0 & - & {$[0.2]$} & - & - & - & - \\
\hline Boron & 3 & 915 & $02 / 21 / 02$ & $\mathrm{~F}$ & 1 & 1 & 4.51 & - & - & - & 750 & $0 / 1$ \\
\hline Boron & 3 & 915 & $02 / 21 / 02$ & NF & 1 & 1 & 5.24 & - & - & - & - & - \\
\hline Bromide & 3 & 915 & 02/21/02 & $\mathrm{F}$ & 1 & 0 & - & [200] & - & - & - & - \\
\hline Cadmium & 3 & 915 & 02/21/02 & $\mathrm{F}$ & 1 & 0 & - & {$[1]$} & 5 & $0 / 2$ & 10 & $0 / 2$ \\
\hline
\end{tabular}


Table A-20 (continued)

\begin{tabular}{|c|c|c|c|c|c|c|c|c|c|c|c|c|}
\hline $\begin{array}{l}\text { Parameter } \\
\text { and } \\
\text { Analyte }\end{array}$ & Screen & $\begin{array}{c}\text { Depth } \\
(\mathrm{ft})^{\mathrm{a}}\end{array}$ & $\begin{array}{l}\text { Collection } \\
\text { Date }\end{array}$ & $\begin{array}{c}\text { Field } \\
\text { Preparation }\end{array}$ & $\begin{array}{l}\text { Number } \\
\text { of } \\
\text { Analyses }\end{array}$ & $\begin{array}{l}\text { Number } \\
\text { of } \\
\text { Detects }\end{array}$ & $\begin{array}{l}\text { Detected } \\
\text { Value } \\
\text { ( } \mu \mathrm{g} / \mathrm{L})\end{array}$ & $\begin{array}{l}\text { Non- } \\
\text { detected } \\
\text { Value } \\
(\mu \mathrm{g} / \mathrm{L})\end{array}$ & $\begin{array}{l}\text { Drinking } \\
\text { Water } \\
\text { MCL }^{b} \\
(\mu \mathrm{g} / \mathrm{L})\end{array}$ & $\begin{array}{l}\text { Frequency } \\
\text { of Detects } \\
>\text { Drinking } \\
\text { Water MCL }\end{array}$ & $\begin{array}{c}\text { NMED }^{c} \\
\text { Groundwater } \\
\text { Standard } \\
(\mu \mathrm{g} / \mathrm{L})\end{array}$ & $\begin{array}{c}\text { Frequency of } \\
\text { Detects }>\text { NMED } \\
\text { Groundwater } \\
\text { Standard }\end{array}$ \\
\hline Cadmium & 3 & 915 & 02/21/02 & NF & 1 & 0 & - & [1] & - & - & - & - \\
\hline Calcium & 3 & 915 & 02/21/02 & $\mathrm{F}$ & 1 & 1 & 15200 & - & - & - & - & - \\
\hline Calcium & 3 & 915 & $02 / 21 / 02$ & NF & 1 & 1 & 14600 & - & - & - & - & - \\
\hline Chloride & 3 & 915 & $02 / 21 / 02$ & $\mathrm{~F}$ & 1 & 1 & 1980 & - & 250000 & $0 / 1$ & 250000 & $0 / 1$ \\
\hline Chromium & 3 & 915 & $02 / 21 / 02$ & $\mathrm{~F}$ & 1 & 0 & - & [5] & 100 & $0 / 1$ & 50 & $0 / 1$ \\
\hline Chromium & 3 & 915 & 02/21/02 & NF & 1 & 1 & 2.1 & - & - & - & - & - \\
\hline Cobalt & 3 & 915 & $02 / 21 / 02$ & $\mathrm{~F}$ & 1 & 1 & 3.28 & - & - & - & 50 & $0 / 1$ \\
\hline Cobalt & 3 & 915 & $02 / 21 / 02$ & NF & 1 & 1 & 3.23 & - & - & - & - & - \\
\hline Copper & 3 & 915 & $02 / 21 / 02$ & $\mathrm{~F}$ & 1 & 0 & - & [5] & 1300 & $0 / 1$ & 1000 & $0 / 1$ \\
\hline Copper & 3 & 915 & $02 / 21 / 02$ & NF & 1 & 0 & - & [5] & - & - & - & - \\
\hline Cyanide (total) & 3 & 915 & $02 / 21 / 02$ & NF & 1 & 0 & - & [5] & - & - & - & - \\
\hline Fluoride & 3 & 915 & $02 / 21 / 02$ & $\mathrm{~F}$ & 1 & 1 & 330 & - & 4000 & $0 / 1$ & 1600 & $0 / 1$ \\
\hline Iron & 3 & 915 & $02 / 21 / 02$ & $\mathrm{~F}$ & 1 & 1 & 8750 & - & 300 & $1 / 1$ & 1000 & $1 / 1$ \\
\hline Iron & 3 & 915 & $02 / 21 / 02$ & NF & 1 & 1 & 8640 & - & - & - & - & - \\
\hline Lead & 3 & 915 & 02/21/02 & $\mathrm{F}$ & 1 & 0 & - & [2] & 15 & $0 / 2$ & 50 & $0 / 2$ \\
\hline Lead & 3 & 915 & $02 / 21 / 02$ & NF & 1 & 1 & - & [0.18] & - & - & - & - \\
\hline Magnesium & 3 & 915 & $02 / 21 / 02$ & $\mathrm{~F}$ & 1 & 1 & 4310 & - & - & - & - & - \\
\hline Magnesium & 3 & 915 & $02 / 21 / 02$ & NF & 1 & 1 & 4120 & - & - & - & - & - \\
\hline Manganese & 3 & 915 & $02 / 21 / 02$ & $\mathrm{~F}$ & 1 & 1 & 2320 & - & 50 & $1 / 1$ & 200 & $1 / 1$ \\
\hline Manganese & 3 & 915 & 02/21/02 & NF & 1 & 1 & 2050 & - & - & - & - & - \\
\hline Mercury & 3 & 915 & $02 / 21 / 02$ & $\mathrm{~F}$ & 1 & 0 & - & {$[0.2]$} & 2 & $0 / 1$ & - & - \\
\hline Mercury & 3 & 915 & $02 / 21 / 02$ & NF & 1 & 0 & - & {$[0.2]$} & - & - & 2 & $0 / 1$ \\
\hline Molybdenum & 3 & 915 & $02 / 21 / 02$ & $\mathrm{~F}$ & 1 & 1 & 11.6 & - & - & - & - & - \\
\hline Molybdenum & 3 & 915 & $02 / 21 / 02$ & NF & 1 & 1 & 11.8 & - & - & - & - & - \\
\hline Nickel & 3 & 915 & $02 / 21 / 02$ & $\mathrm{~F}$ & 1 & 1 & 27.7 & - & 100 & $0 / 1$ & 200 & $0 / 1$ \\
\hline Nickel & 3 & 915 & $02 / 21 / 02$ & NF & 1 & 1 & 28.3 & - & - & - & - & - \\
\hline Nitrate + Nitrite (as N) & 3 & 915 & $02 / 21 / 02$ & $\mathrm{~F}$ & 1 & 0 & - & [50] & 10000 & $0 / 1$ & - & - \\
\hline
\end{tabular}


Table A-20 (continued)

\begin{tabular}{|c|c|c|c|c|c|c|c|c|c|c|c|c|}
\hline $\begin{array}{l}\text { Parameter } \\
\text { and } \\
\text { Analyte }\end{array}$ & Screen & $\begin{array}{l}\text { Depth } \\
\text { (ft) }\end{array}$ & $\begin{array}{l}\text { Collection } \\
\text { Date }\end{array}$ & $\begin{array}{c}\text { Field } \\
\text { Preparation }\end{array}$ & $\begin{array}{l}\text { Number } \\
\text { of } \\
\text { Analyses }\end{array}$ & $\begin{array}{l}\text { Number } \\
\text { of } \\
\text { Detects }\end{array}$ & $\begin{array}{l}\text { Detected } \\
\text { Value } \\
(\mu \mathrm{g} / \mathrm{L})\end{array}$ & $\begin{array}{l}\text { Non- } \\
\text { detected } \\
\text { Value } \\
(\mu \mathrm{g} / \mathrm{L})\end{array}$ & $\begin{array}{l}\text { Drinking } \\
\text { Water } \\
M C L^{b} \\
(\mu \mathrm{g} / \mathrm{L})\end{array}$ & $\begin{array}{l}\text { Frequency } \\
\text { of Detects } \\
>\text { Drinking } \\
\text { Water MCL }\end{array}$ & $\begin{array}{c}\text { NMED }^{c} \\
\text { Groundwater } \\
\text { Standard } \\
(\mu \mathrm{g} / \mathrm{L})\end{array}$ & $\begin{array}{c}\text { Frequency of } \\
\text { Detects }>\text { NMED } \\
\text { Groundwater } \\
\text { Standard }\end{array}$ \\
\hline Perchlorate & 3 & 915 & $02 / 21 / 02$ & $\mathrm{~F}$ & 1 & 0 & - & [4] & - & - & - & - \\
\hline Phosphorus (total) & 3 & 915 & $02 / 21 / 02$ & $\mathrm{~F}$ & 1 & 1 & 20 & - & - & - & - & - \\
\hline Potassium & 3 & 915 & $02 / 21 / 02$ & $\mathrm{~F}$ & 1 & 1 & 2260 & - & - & - & - & - \\
\hline Selenium & 3 & 915 & $02 / 21 / 02$ & $\mathrm{NF}$ & 1 & 0 & - & [5] & - & - & - & - \\
\hline Silica & 3 & 915 & $02 / 21 / 02$ & $\mathrm{~F}$ & 1 & 1 & 53286 & - & - & - & - & - \\
\hline Silica & 3 & 915 & $02 / 21 / 02$ & $\mathrm{NF}$ & 1 & 1 & 50290 & - & - & - & - & - \\
\hline Silver & 3 & 915 & $02 / 21 / 02$ & $\mathrm{~F}$ & 1 & 0 & - & [5] & 100 & $0 / 1$ & 50 & $0 / 1$ \\
\hline Silver & 3 & 915 & $02 / 21 / 02$ & $\mathrm{NF}$ & 1 & 0 & - & [5] & - & - & - & - \\
\hline Strontium & 3 & 915 & $02 / 21 / 02$ & NF & 1 & 1 & 87.4 & - & - & - & - & - \\
\hline Sulfate & 3 & 915 & $02 / 21 / 02$ & $\mathrm{~F}$ & 1 & 1 & 409 & - & 250000 & $0 / 1$ & 600000 & $0 / 1$ \\
\hline Thallium & 3 & 915 & $02 / 21 / 02$ & $\mathrm{~F}$ & 1 & 0 & - & [0.02] & 2 & $0 / 2$ & - & - \\
\hline Thallium & 3 & 915 & $02 / 21 / 02$ & NF & 1 & 1 & - & {$[0.5]$} & - & - & - & - \\
\hline $\begin{array}{l}\text { Total Kjeldahl } \\
\text { Nitrogen }\end{array}$ & 3 & 915 & $02 / 21 / 02$ & $\mathrm{~F}$ & 1 & 1 & 1060 & - & - & - & - & - \\
\hline $\begin{array}{l}\text { Total Kjeldahl } \\
\text { Nitrogen }\end{array}$ & 3 & 915 & $02 / 21 / 02$ & $\mathrm{NF}$ & 1 & 1 & 910 & - & - & - & - & - \\
\hline Uranium & 3 & 915 & $02 / 21 / 02$ & $\mathrm{~F}$ & 1 & 0 & - & [0.12] & 20 & $0 / 1$ & 5000 & $0 / 1$ \\
\hline Uranium & 3 & 915 & $02 / 21 / 02$ & $\mathrm{NF}$ & 1 & 0 & - & [0.14] & - & - & - & - \\
\hline Vanadium & 3 & 915 & $02 / 21 / 02$ & $\mathrm{~F}$ & 1 & 0 & - & [5] & - & - & - & - \\
\hline Vanadium & 3 & 915 & $02 / 21 / 02$ & $\mathrm{NF}$ & 1 & 0 & - & [5] & - & - & - & - \\
\hline Zinc & 3 & 915 & $02 / 21 / 02$ & $\mathrm{~F}$ & 1 & 1 & 11.6 & - & 5000 & $0 / 1$ & 10000 & $0 / 1$ \\
\hline Zinc & 3 & 915 & $02 / 21 / 02$ & $\mathrm{NF}$ & 1 & 1 & 19.9 & - & - & - & - & - \\
\hline
\end{tabular}


Table A-20 (continued)

\begin{tabular}{|c|c|c|c|c|c|c|c|c|c|c|c|c|}
\hline $\begin{array}{l}\text { Parameter } \\
\text { and } \\
\text { Analyte }\end{array}$ & Screen & $\begin{array}{l}\text { Depth } \\
(\mathrm{ftt})^{a}\end{array}$ & $\begin{array}{l}\text { Collection } \\
\text { Date }\end{array}$ & $\begin{array}{c}\text { Field } \\
\text { Preparation }\end{array}$ & $\begin{array}{l}\text { Number } \\
\text { of } \\
\text { Analyses }\end{array}$ & $\begin{array}{l}\text { Number } \\
\text { of } \\
\text { Detects }\end{array}$ & $\begin{array}{l}\text { Detected } \\
\text { Value } \\
(\mu \mathrm{g} / \mathrm{L})\end{array}$ & $\begin{array}{l}\text { Non- } \\
\text { detected } \\
\text { Value } \\
(\mu \mathrm{g} / \mathrm{L})\end{array}$ & $\begin{array}{l}\text { Drinking } \\
\text { Water } \\
M C L^{b} \\
(\mu \mathrm{g} / \mathrm{L})\end{array}$ & $\begin{array}{l}\text { Frequency } \\
\text { of Detects } \\
>\text { Drinking } \\
\text { Water MCL }\end{array}$ & $\begin{array}{c}\text { NMEDC } \\
\text { Groundwater } \\
\text { Standard } \\
(\mu \mathrm{g} / \mathrm{L})\end{array}$ & $\begin{array}{c}\text { Frequency of } \\
\text { Detects }>\text { NMED } \\
\text { Groundwater } \\
\text { Standard }\end{array}$ \\
\hline \multicolumn{13}{|c|}{ Stable Isotope (\%o) } \\
\hline$\delta \mathrm{D}$ & 3 & 915 & $02 / 21 / 02$ & $\mathrm{NF}$ & 1 & 1 & -83 & - & - & - & - & - \\
\hline$\delta^{15} \mathrm{~N}\left(\mathrm{NO}_{3}\right)$ & 3 & 915 & $02 / 21 / 02$ & $\mathrm{NF}$ & 1 & 1 & ISVi & - & - & - & - & - \\
\hline$\delta^{18} \mathrm{O}$ & 3 & 915 & $02 / 21 / 02$ & $\mathrm{NF}$ & 1 & 1 & -11.5 & - & - & - & - & - \\
\hline
\end{tabular}

The static water level for the regional aquifer at R-7 was $902.8 \mathrm{ft}$ when the well was drilled.

${ }^{\mathrm{b}} \mathrm{MCL}=$ Maximum contaminant level. US Environmental Protection Agency (EPA) MCLs are from National Primary Drinking Water Regulations, 40 CFR Part 141. US EPA secondary MCLs are from National Secondary Drinking Water Regulations, 40 CFR Part 143. State of New Mexico MCLs are from Drinking Water Regulations, 20 NMAC 7.1.

${ }^{c}$ NMED = New Mexico Environment Department.

d State of New Mexico groundwater standards are from New Mexico Water Quality Control Commission Regulations, Ground and Surface Water Protection, 20 NMAC 6.2.

$\mathrm{NF}=$ Nonfiltered

f $-=$ Not available or not applicable

${ }^{g}$ NTU = Nephelometric turbidity unit.

$\mathrm{h} F=$ Filtered

i ISV = Insufficient sample volume for analysis. 
Table A-21

Regional Well R-7 Screen 1 Fourth Round Sample Results: Data Summary for Detected Organic Chemicals

\begin{tabular}{|c|c|c|c|c|c|c|c|c|c|c|c|c|}
\hline Analyte & Screen & $\begin{array}{l}\text { Depth } \\
\text { (ft) }\end{array}$ & $\begin{array}{c}\text { Collection } \\
\text { Date }\end{array}$ & $\begin{array}{c}\text { Field } \\
\text { Preparation }\end{array}$ & $\begin{array}{l}\text { Number } \\
\text { of } \\
\text { Analyses }\end{array}$ & $\begin{array}{l}\text { Number } \\
\text { of } \\
\text { Detects }\end{array}$ & $\begin{array}{c}\text { Detected } \\
\text { Value } \\
\text { ( } \mu \mathrm{g} / \mathrm{L})\end{array}$ & $\begin{array}{c}\text { Non- } \\
\text { detected } \\
\text { Value } \\
(\mu \mathrm{g} / \mathrm{L})\end{array}$ & $\begin{array}{l}\text { Drinking } \\
\text { Water } \\
\text { MCL }^{\mathrm{b}} \\
(\mu \mathrm{g} / \mathrm{L})\end{array}$ & $\begin{array}{l}\text { Frequency } \\
\text { of Detects } \\
>\text { Drinking } \\
\text { Water MCL }\end{array}$ & $\begin{array}{c}\text { NMED }^{c} \\
\text { Groundwater } \\
\text { Standard }^{\mathrm{d}} \\
(\mu \mathrm{g} / \mathrm{L})\end{array}$ & $\begin{array}{l}\text { Frequency of } \\
\text { Detects }>\text { NMED } \\
\text { Groundwater } \\
\text { Standard }\end{array}$ \\
\hline Bis(2-ethylhexyl)phthalate & 1 & 378 & 02/19/02 & NF & 1 & 1 & 18.7 & - & 6 & $1 / 1$ & - & - \\
\hline Dissolved Organic Carbon & 1 & 378 & 02/19/02 & $\mathrm{F}^{\mathrm{g}}$ & 1 & 1 & 670 & - & - & - & - & - \\
\hline Methylene Chloride & 1 & 378 & 02/19/02 & NF & 1 & 1 & 4.4 & - & 5 & $0 / 1$ & 100 & $0 / 1$ \\
\hline Total Organic Carbon & 1 & 378 & 02/19/02 & NF & 1 & 1 & 237 & - & - & - & - & - \\
\hline
\end{tabular}

${ }^{\text {a }}$ The static water level for the regional aquifer at R-7 was $902.8 \mathrm{ft}$ when the well was drilled.

${ }^{\mathrm{b}} \mathrm{MCL}=$ Maximum contaminant level. US Environmental Protection Agency (EPA) MCLs are from National Primary Drinking Water Regulations, 40 CFR Part 141. US EPA secondary MCLs are from National Secondary Drinking Water Regulations, 40 CFR Part 143. State of New Mexico MCLs are from Drinking Water Regulations, 20 NMAC 7.1.

${ }_{\mathrm{d}}^{\mathrm{c}}$ NMED $=$ New Mexico Environment Department.

${ }^{\mathrm{d}}$ State of New Mexico groundwater standards are from New Mexico Water Quality Control Commission Regulations, Ground and Surface Water Protection, 20 NMAC 6.2.

${ }_{\mathrm{N}}^{\mathrm{N}}=$ Nonfiltered.

$f-=$ Not available or not applicable

${ }^{\mathrm{g}} \mathrm{F}=$ Filtered 
Table A-22

Regional Well R-7 Screen 3 Fourth Round Sample Results: Data Summary for Detected Organic Chemicals

\begin{tabular}{|c|c|c|c|c|c|c|c|c|c|c|c|c|}
\hline Analyte & Screen & $\begin{array}{c}\text { Depth } \\
\text { (ft) }\end{array}$ & $\begin{array}{l}\text { Collection } \\
\text { Date }\end{array}$ & $\begin{array}{c}\text { Field } \\
\text { Preparation }\end{array}$ & $\begin{array}{c}\text { Number } \\
\text { of } \\
\text { Analyses }\end{array}$ & $\begin{array}{l}\text { Number } \\
\text { of } \\
\text { Detects }\end{array}$ & $\begin{array}{l}\text { Detected } \\
\text { Value } \\
\text { ( } \mu \mathrm{g} / \mathrm{L})\end{array}$ & $\begin{array}{l}\text { Non- } \\
\text { detected } \\
\text { Value } \\
(\mu \mathrm{g} / \mathrm{L})\end{array}$ & $\begin{array}{l}\text { Drinking } \\
\text { Water } \\
M C^{b} \\
(\mu \mathrm{g} / \mathrm{L})\end{array}$ & $\begin{array}{l}\text { Frequency } \\
\text { of Detects } \\
>\text { Drinking } \\
\text { Water MCL }\end{array}$ & $\begin{array}{c}\text { NMED }^{c} \\
\text { Groundwater } \\
\text { Standard }^{d} \\
(\mu \mathrm{g} / \mathrm{L})\end{array}$ & $\begin{array}{c}\text { Frequency of } \\
\text { Detects }>\text { NMED } \\
\text { Groundwater } \\
\text { Standard }\end{array}$ \\
\hline Acetone & 3 & 915 & $02 / 21 / 02$ & $\mathrm{NF}^{\mathrm{e}}$ & 1 & 1 & 5.6 & $-^{f}$ & - & - & - & - \\
\hline Dissolved Organic Carbon & 3 & 915 & $02 / 21 / 02$ & $\mathrm{~F}^{\mathrm{g}}$ & 1 & 1 & 3200 & - & - & - & - & - \\
\hline $\begin{array}{l}\text { Humic Substances, } \\
\text { Hydrophilic Acids }\end{array}$ & 3 & 915 & $02 / 21 / 02$ & $\mathrm{~F}$ & 1 & 1 & 1400 & 一 & - & - & - & - \\
\hline $\begin{array}{l}\text { Humic Substances, } \\
\text { Hydrophilic Bases }\end{array}$ & 3 & 915 & $02 / 21 / 02$ & $\mathrm{~F}$ & 1 & 1 & 100 & 一 & - & 一 & 一 & - \\
\hline $\begin{array}{l}\text { Humic Substances, } \\
\text { Hydrophilic Neutrals }\end{array}$ & 3 & 915 & $02 / 21 / 02$ & $\mathrm{~F}$ & 1 & 1 & 200 & 一 & - & 一 & - & - \\
\hline $\begin{array}{l}\text { Humic Substances, } \\
\text { Hydrophilic Total }\end{array}$ & 3 & 915 & $02 / 21 / 02$ & $\mathrm{~F}$ & 1 & 1 & 1700 & 一 & 一 & 一 & 一 & - \\
\hline $\begin{array}{l}\text { Humic Substances, } \\
\text { Hydrophobic Acids }\end{array}$ & 3 & 915 & $02 / 21 / 02$ & $\mathrm{~F}$ & 1 & 1 & 700 & - & 一 & - & - & - \\
\hline $\begin{array}{l}\text { Humic Substances, } \\
\text { Hydrophobic Bases }\end{array}$ & 3 & 915 & $02 / 21 / 02$ & $\mathrm{~F}$ & 1 & 1 & - & [100] & - & - & - & - \\
\hline $\begin{array}{l}\text { Humic Substances, } \\
\text { Hydrophobic Neutrals }\end{array}$ & 3 & 915 & $02 / 21 / 02$ & $\mathrm{~F}$ & 1 & 1 & 800 & - & 一 & - & - & - \\
\hline $\begin{array}{l}\text { Humic Substances, } \\
\text { Hydrophobic Total }\end{array}$ & 3 & 915 & $02 / 21 / 02$ & $\mathrm{~F}$ & 1 & 1 & 1500 & - & - & - & - & - \\
\hline Isopropylbenzene & 3 & 915 & $02 / 21 / 02$ & NF & 1 & 1 & 0.94 & - & - & - & - & - \\
\hline Nitrosodiphenylamine[N-] & 3 & 915 & $02 / 21 / 02$ & NF & 1 & 1 & 9.6 & - & - & - & - & - \\
\hline Total Organic Carbon & 3 & 915 & $02 / 21 / 02$ & NF & 1 & 1 & 3690 & - & - & - & - & - \\
\hline
\end{tabular}

a The static water level for the regional aquifer at R-7 was $902.8 \mathrm{ft}$ when the well was drilled.

${ }^{\mathrm{b}} \mathrm{MCL}=$ Maximum contaminant level. US Environmental Protection Agency (EPA) MCLs are from National Primary Drinking Water Regulations, 40 CFR Part 141. US EPA secondary MCLs are from National Secondary Drinking Water Regulations, 40 CFR Part 143. State of New Mexico MCLs are from Drinking Water Regulations, 20 NMAC 7.1.

${ }^{c}$ NMED $=$ New Mexico Environment Department.

d State of New Mexico groundwater standards are from New Mexico Water Quality Control Commission Regulations, Ground and Surface Water Protection, 20 NMAC 6.2

${ }^{\mathrm{e}} \mathrm{NF}=$ Nonfiltered.

$\mathrm{f}-\mathrm{N}$ Not available or not applicable.

${ }^{\mathrm{g}} \mathrm{F}=$ Filtered 
Table A-23

Regional Well R-7 Screen 1 Fourth Round Sample Results: Data Summary for Radionuclides

\begin{tabular}{|c|c|c|c|c|c|c|c|c|c|c|}
\hline Analyte & Screen & $\begin{array}{l}\text { Depth } \\
(\mathrm{ft})^{\mathrm{a}}\end{array}$ & $\begin{array}{l}\text { Collection } \\
\text { Date }\end{array}$ & $\begin{array}{c}\text { Field } \\
\text { Preparation }\end{array}$ & $\begin{array}{l}\text { Number of } \\
\text { Analyses }\end{array}$ & $\begin{array}{l}\text { Number of } \\
\text { Detects }\end{array}$ & $\begin{array}{l}\text { Detected } \\
\text { Value } \\
\text { (pCi/L) }\end{array}$ & $\begin{array}{l}\text { Nondetected } \\
\text { Value } \\
\text { (pCi/L) }\end{array}$ & $\begin{array}{l}\text { Drinking } \\
\text { Water MCL } \\
\quad(p C i / L)\end{array}$ & $\begin{array}{c}\text { Frequency of } \\
\text { Detects }>\text { Drinking } \\
\text { Water MCL }\end{array}$ \\
\hline Americium-241 & 1 & 378 & 02/19/02 & $\mathrm{F}^{\mathrm{C}}$ & 1 & 0 & $-^{d}$ & [0.0186] & $15^{\mathrm{e}}$ & $0 / 1$ \\
\hline Americium-241 & 1 & 378 & 02/19/02 & $\mathrm{NF}^{f}$ & 1 & 0 & - & [0.00803] & - & - \\
\hline Cesium-134 & 1 & 378 & 02/19/02 & $\mathrm{F}$ & 1 & 0 & - & {$[-0.341]$} & - & - \\
\hline Cesium-134 & 1 & 378 & 02/19/02 & NF & 1 & 0 & - & [0.452] & - & - \\
\hline Cesium-137 & 1 & 378 & 02/19/02 & $\mathrm{F}$ & 1 & 0 & - & [0.0294] & - & - \\
\hline Cesium-137 & 1 & 378 & 02/19/02 & NF & 1 & 0 & - & [0.703] & - & - \\
\hline Cobalt-60 & 1 & 378 & 02/19/02 & $\mathrm{F}$ & 1 & 0 & - & [0.825] & - & - \\
\hline Cobalt-60 & 1 & 378 & 02/19/02 & NF & 1 & 0 & - & {$[-0.175]$} & - & - \\
\hline Europium-152 & 1 & 378 & 02/19/02 & $\mathrm{F}$ & 1 & 0 & - & {$[-0.927]$} & - & - \\
\hline Europium-152 & 1 & 378 & 02/19/02 & NF & 1 & 0 & - & {$[-1.33]$} & - & - \\
\hline Gross Alpha Radiation & 1 & 378 & 02/19/02 & NF & 1 & 0 & - & [0.478] & - & - \\
\hline Gross Beta Radiation & 1 & 378 & 02/19/02 & NF & 1 & 1 & 3.02 & - & - & - \\
\hline Plutonium-238 & 1 & 378 & 02/19/02 & $\mathrm{F}$ & 1 & 0 & - & {$[-0.0008]$} & 15 & $0 / 1$ \\
\hline Plutonium-238 & 1 & 378 & 02/19/02 & NF & 1 & 0 & - & {$[0.00867]$} & - & - \\
\hline Plutonium-239,240 & 1 & 378 & 02/19/02 & $\mathrm{F}$ & 1 & 0 & - & {$[-0.0008]$} & - & - \\
\hline Plutonium-239,240 & 1 & 378 & 02/19/02 & NF & 1 & 0 & - & {$[0.00217]$} & - & - \\
\hline Ruthenium-106 & 1 & 378 & 02/19/02 & $\mathrm{F}$ & 1 & 0 & - & [2.59] & - & - \\
\hline Ruthenium-106 & 1 & 378 & 02/19/02 & NF & 1 & 0 & - & [5.08] & - & - \\
\hline Sodium-22 & 1 & 378 & 02/19/02 & $\mathrm{F}$ & 1 & 0 & - & [0.145] & - & - \\
\hline Sodium-22 & 1 & 378 & 02/19/02 & NF & 1 & 0 & - & {$[-0.953]$} & - & - \\
\hline Strontium-90 & 1 & 378 & 02/19/02 & $\mathrm{F}$ & 1 & 0 & - & {$[-0.0499]$} & 8 & $0 / 1$ \\
\hline Strontium-90 & 1 & 378 & 02/19/02 & NF & 1 & 0 & - & {$[-0.0001]$} & - & - \\
\hline Technetium-99 & 1 & 378 & $02 / 19 / 02$ & NF & 1 & 0 & - & {$[-3.8]$} & - & - \\
\hline Tritium & 1 & 378 & 02/19/02 & NF & 1 & 1 & 3.26 & - & 20000 & $0 / 1$ \\
\hline Uranium-234 & 1 & 378 & 02/19/02 & $\mathrm{F}$ & 1 & 1 & 0.0478 & - & - & - \\
\hline Uranium-234 & 1 & 378 & 02/19/02 & NF & 1 & 0 & - & {$[0.0275]$} & - & - \\
\hline Uranium-235 & 1 & 378 & 02/19/02 & $\mathrm{F}$ & 1 & 0 & - & [0.00533] & - & - \\
\hline
\end{tabular}




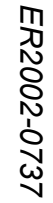

Table A-23 (continued)

\begin{tabular}{|c|c|c|c|c|c|c|c|c|c|c|}
\hline Analyte & Screen & $\begin{array}{l}\text { Depth } \\
\text { (ft) }\end{array}$ & $\begin{array}{l}\text { Collection } \\
\text { Date }\end{array}$ & $\begin{array}{c}\text { Field } \\
\text { Preparation }\end{array}$ & $\begin{array}{l}\text { Number of } \\
\text { Analyses }\end{array}$ & $\begin{array}{l}\text { Number of } \\
\text { Detects }\end{array}$ & $\begin{array}{l}\text { Detected } \\
\text { Value } \\
\text { (pCi/L) }\end{array}$ & $\begin{array}{l}\text { Nondetected } \\
\text { Value } \\
\text { (pCi/L) }\end{array}$ & $\begin{array}{c}\text { Drinking } \\
\text { Water MCL }^{\mathrm{b}} \\
\text { (pCi/L) }\end{array}$ & $\begin{array}{c}\text { Frequency of } \\
\text { Detects }>\text { Drinking } \\
\text { Water MCL }\end{array}$ \\
\hline Uranium-235 & 1 & 378 & $02 / 19 / 02$ & $\mathrm{NF}$ & 1 & 0 & - & {$[0]$} & - & - \\
\hline Uranium-238 & 1 & 378 & 02/19/02 & $\mathrm{F}$ & 1 & 0 & - & {$[0.0106]$} & - & - \\
\hline Uranium-238 & 1 & 378 & 02/19/02 & $\mathrm{NF}$ & 1 & 0 & - & {$[0.0138]$} & - & - \\
\hline
\end{tabular}

a The static water level for the regional aquifer at R-7 was $902.8 \mathrm{ft}$ when the well was drilled.

${ }^{\mathrm{b}} \mathrm{MCL}=$ Maximum contaminant level. US Environmental Protection Agency (EPA) MCLs are from National Primary Drinking Water Regulations, 40 CFR Part 141. US EPA secondary MCLs are from National Secondary Drinking Water Regulations, 40 CFR Part 143. State of New Mexico MCLs are from Drinking Water Regulations, 20 NMAC 7.1.

${ }^{c} \mathrm{~F}=$ Filtered

d $-=$ Not available or not applicable

e Based on an MCL of $15 \mathrm{pCi} / \mathrm{L}$ (including radium-226, but excluding radon and uranium).

${ }^{f} \mathrm{NF}=$ Nonfiltered. 
Table A-24

Regional Well R-7 Screen 3 Fourth Round Sample Results: Data Summary for Radionuclides

\begin{tabular}{|c|c|c|c|c|c|c|c|c|c|c|}
\hline Analyte & Screen & $\begin{array}{l}\text { Depth } \\
\text { (ft) }\end{array}$ & $\begin{array}{c}\text { Collection } \\
\text { Date }\end{array}$ & $\begin{array}{c}\text { Field } \\
\text { Preparation }\end{array}$ & $\begin{array}{l}\text { Number of } \\
\text { Analyses }\end{array}$ & $\begin{array}{l}\text { Number of } \\
\text { Detects }\end{array}$ & $\begin{array}{c}\text { Detected } \\
\text { Value } \\
\text { (pCi/L) }\end{array}$ & $\begin{array}{c}\text { Nondetected } \\
\text { Value } \\
\text { (pCi/L) }\end{array}$ & $\begin{array}{c}\text { Drinking } \\
\text { Water MCL } \\
(p C i / L)\end{array}$ & $\begin{array}{c}\text { Frequency of } \\
\text { Detects > Drinking } \\
\text { Water MCL }\end{array}$ \\
\hline Americium-241 & 3 & 915 & $02 / 21 / 02$ & $\mathrm{~F}^{\mathrm{C}}$ & 1 & 0 & $-^{d}$ & {$[0.00373]$} & $15^{\mathrm{e}}$ & $0 / 1$ \\
\hline Americium-241 & 3 & 915 & $02 / 21 / 02$ & $\mathrm{NF}^{f}$ & 1 & 1 & 0.0253 & - & - & - \\
\hline Cesium-134 & 3 & 915 & $02 / 21 / 02$ & $\mathrm{NF}$ & 1 & 0 & - & {$[0.467]$} & - & - \\
\hline Cesium-137 & 3 & 915 & $02 / 21 / 02$ & NF & 1 & 0 & - & {$[-0.682]$} & - & - \\
\hline Cobalt-60 & 3 & 915 & $02 / 21 / 02$ & NF & 1 & 0 & - & {$[0.166]$} & - & - \\
\hline Europium-152 & 3 & 915 & $02 / 21 / 02$ & $\mathrm{NF}$ & 1 & 0 & - & [1.2] & - & - \\
\hline Gross Alpha Radiation & 3 & 915 & $02 / 21 / 02$ & NF & 1 & 0 & - & [1.5] & - & - \\
\hline Gross Beta Radiation & 3 & 915 & $02 / 21 / 02$ & NF & 1 & 1 & 2.59 & - & - & - \\
\hline Plutonium-238 & 3 & 915 & $02 / 21 / 02$ & $\mathrm{~F}$ & 1 & 0 & - & {$[0.00477]$} & 15 & $0 / 1$ \\
\hline Plutonium-238 & 3 & 915 & $02 / 21 / 02$ & NF & 1 & 0 & - & [0.00419] & - & - \\
\hline Plutonium-239,240 & 3 & 915 & $02 / 21 / 02$ & $\mathrm{~F}$ & 1 & 0 & - & {$[0.00716]$} & - & - \\
\hline Plutonium-239,240 & 3 & 915 & $02 / 21 / 02$ & $\mathrm{NF}$ & 1 & 0 & - & {$[0.0168]$} & - & - \\
\hline Ruthenium-106 & 3 & 915 & $02 / 21 / 02$ & NF & 1 & 0 & - & {$[1.02]$} & - & - \\
\hline Sodium-22 & 3 & 915 & $02 / 21 / 02$ & $\mathrm{NF}$ & 1 & 0 & - & {$[1.42]$} & 一 & - \\
\hline Strontium-90 & 3 & 915 & $02 / 21 / 02$ & $\mathrm{~F}$ & 1 & 0 & - & {$[-0.0447]$} & 8 & $0 / 1$ \\
\hline Strontium-90 & 3 & 915 & $02 / 21 / 02$ & NF & 1 & 0 & - & {$[-0.0427]$} & - & - \\
\hline Technetium-99 & 3 & 915 & $02 / 21 / 02$ & NF & 1 & 0 & - & {$[-3.35]$} & - & - \\
\hline Tritium & 3 & 915 & $02 / 21 / 02$ & NF & 1 & 1 & 1.34 & - & 20000 & $0 / 1$ \\
\hline Uranium-234 & 3 & 915 & $02 / 21 / 02$ & $\mathrm{~F}$ & 1 & 1 & 0.0664 & - & - & - \\
\hline Uranium-234 & 3 & 915 & $02 / 21 / 02$ & $\mathrm{NF}$ & 1 & 1 & 0.0765 & - & - & - \\
\hline Uranium-235 & 3 & 915 & $02 / 21 / 02$ & $\mathrm{~F}$ & 1 & 0 & - & {$[0.0074]$} & - & - \\
\hline Uranium-235 & 3 & 915 & $02 / 21 / 02$ & $\mathrm{NF}$ & 1 & 0 & - & [0.00823] & - & - \\
\hline
\end{tabular}




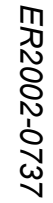

Table A-24 (continued)

\begin{tabular}{|c|c|c|c|c|c|c|c|c|c|c|}
\hline Analyte & Screen & $\begin{array}{l}\text { Depth } \\
\text { (ft) }\end{array}$ & $\begin{array}{l}\text { Collection } \\
\text { Date }\end{array}$ & $\begin{array}{c}\text { Field } \\
\text { Preparation }\end{array}$ & $\begin{array}{l}\text { Number of } \\
\text { Analyses }\end{array}$ & $\begin{array}{c}\text { Number of } \\
\text { Detects }\end{array}$ & $\begin{array}{l}\text { Detected } \\
\text { Value } \\
\text { (pCi/L) }\end{array}$ & $\begin{array}{l}\text { Nondetected } \\
\text { Value } \\
\text { (pCi/L) }\end{array}$ & $\begin{array}{c}\text { Drinking } \\
\text { Water MCL }{ }^{\mathrm{b}} \\
\text { (pCi/L) }\end{array}$ & $\begin{array}{c}\text { Frequency of } \\
\text { Detects }>\text { Drinking } \\
\text { Water MCL }\end{array}$ \\
\hline Uranium-238 & 3 & 915 & 02/21/02 & $\mathrm{F}$ & 1 & 0 & - & {$[0.0344]$} & - & - \\
\hline Uranium-238 & 3 & 915 & $02 / 21 / 02$ & $\mathrm{NF}$ & 1 & 1 & 0.0601 & - & - & - \\
\hline
\end{tabular}

The static water level for the regional aquifer at R-7 was $902.8 \mathrm{ft}$ when the well was drilled

${ }^{\mathrm{b}} \mathrm{MCL}=$ Maximum contaminant level. US Environmental Protection Agency (EPA) MCLs are from National Primary Drinking Water Regulations, 40 CFR Part 141. US EPA secondary MCLs are from National Secondary Drinking Water Regulations, 40 CFR Part 143. State of New Mexico MCLs are from Drinking Water Regulations, 20 NMAC 7.1.

${ }^{\mathrm{c}} \mathrm{F}=$ Filtered

${ }^{d}-=$ Not available or not applicable

Based on an MCL of $15 \mathrm{pCi} / \mathrm{L}$ (including radium-226, but excluding radon and uranium).

${ }^{\mathrm{f}} \mathrm{NF}=$ Nonfiltered. 



\section{Appendix B}

Geochemical Calculations

(Input Files for the Computer Program MINTEQA2) 



\section{APPENDIX B GEOCHEMICAL CALCULATIONS (INPUT FILES FOR THE COMPUTER PROGRAM MINTEQA2)}

A description of the input file for the computer program MINTEQA2 (Allison et al. 1991, 49930) is provided below.

Rows one and two (blank) consist of the title for the calculations.

Row three consists of temperature, units of concentration, and calculation of ionic strength.

Row four is blank.

Row five consists of query for charge balance termination (> $30 \%$ ); alkalinity or inorganic carbon as carbonate; query for oversaturated solids that are not allowed to precipitate excluding infinite and finite phases; maximum number of iterations (40,100, and 200); selection for calculating activity coefficient (Davies equation); level of output; $\mathrm{pH}$; Eh or pe; and a query for choosing a different file to modify or return to output filename prompt.

Row six is blank.

Row seven contains zeros (not specific to input file).

Row eight is blank.

Rows nine through 25 contains species number, concentration, log base 10 activity, a prompt (y) for refining calculation of activity for each species, and the chemical symbol for each species.

Row 26 is blank.

Row 27 consists of $\mathrm{pH}$ input (measured).

Row 28 consists of $\mathrm{pH}$ including its species number, $\mathrm{pH}$ value, and chemical symbol.

Row 29 includes excluded species for calculation

Row 30 consists of excluded species identification number, log base 10 association constant $(\mathrm{K})$ and delta $\mathrm{H}$ (enthalpy) for association constant. Species $\mathrm{U}(\mathrm{OH})_{5}{ }^{-}$was excluded from calculations because spectroscopic data did not confirm its occurrence in aqueous solution (Langmuir 1997, 56037). 


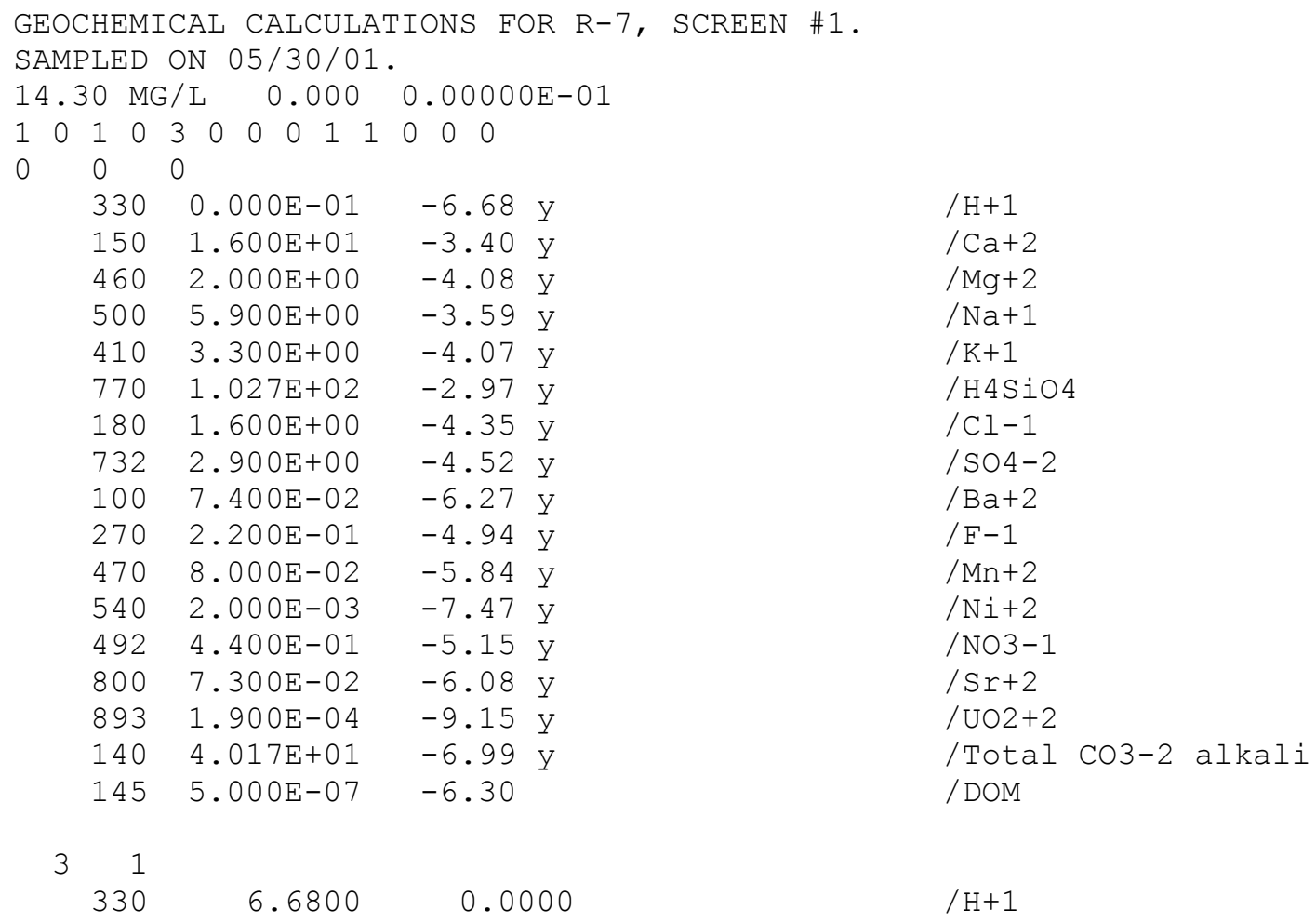




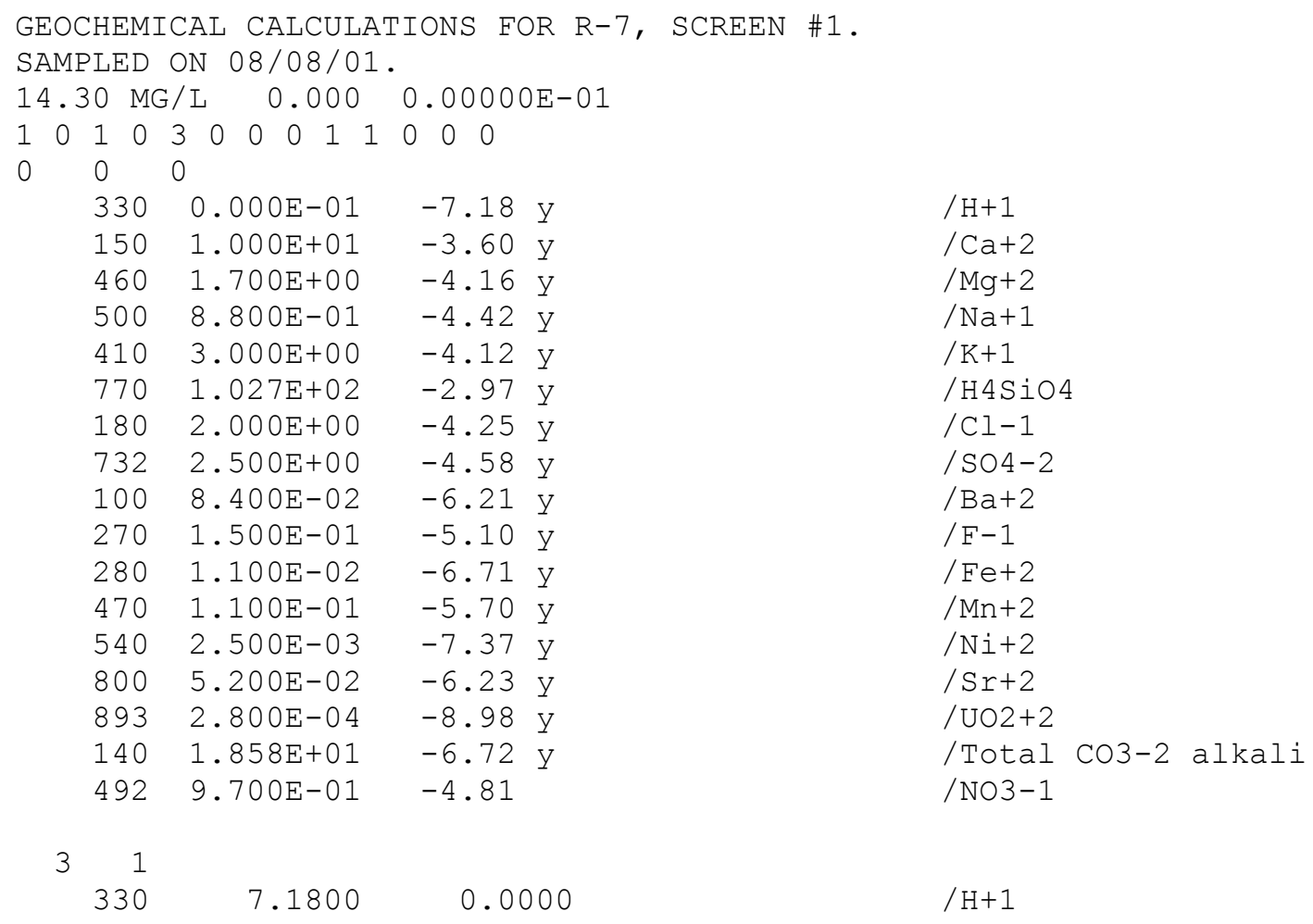




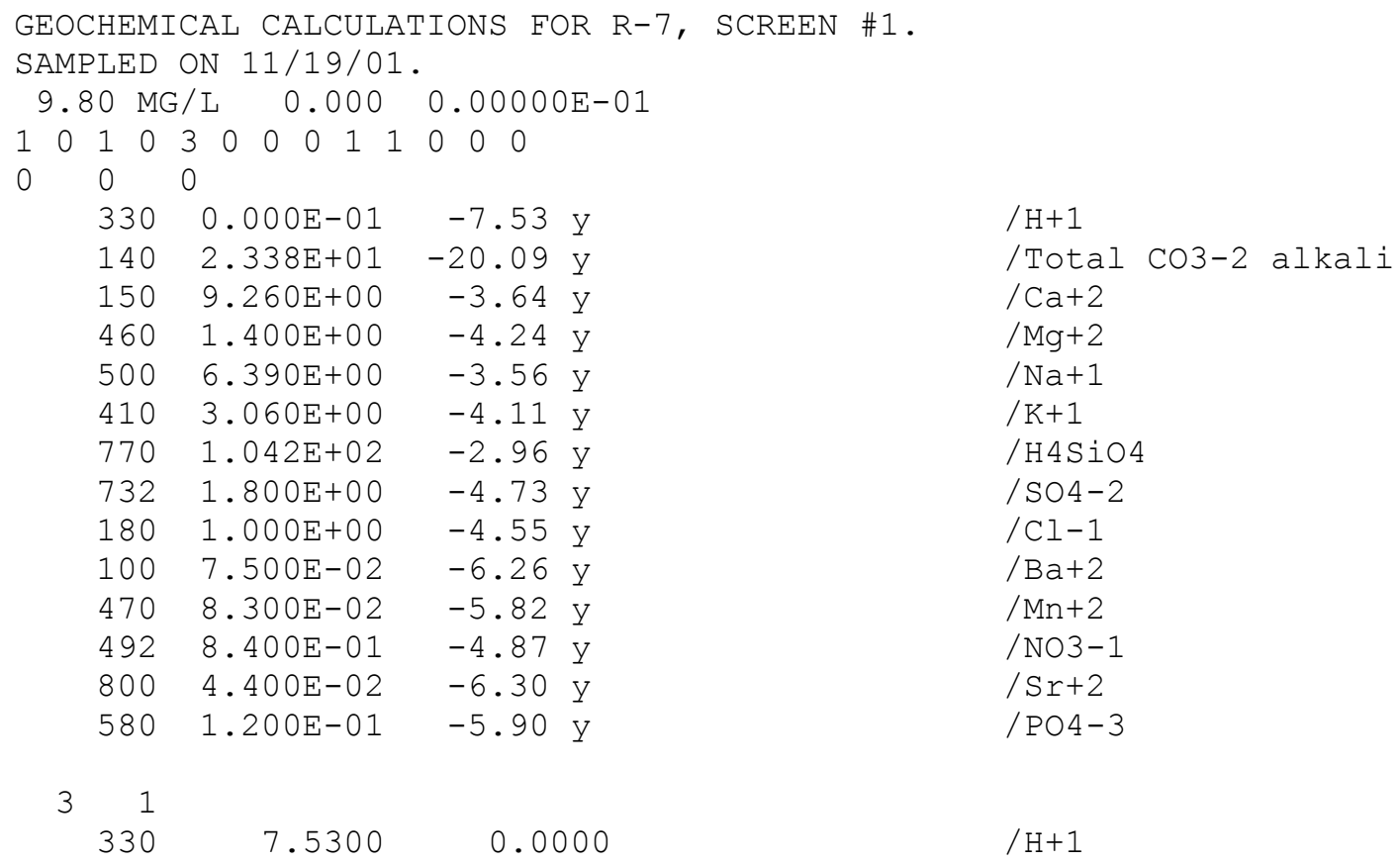




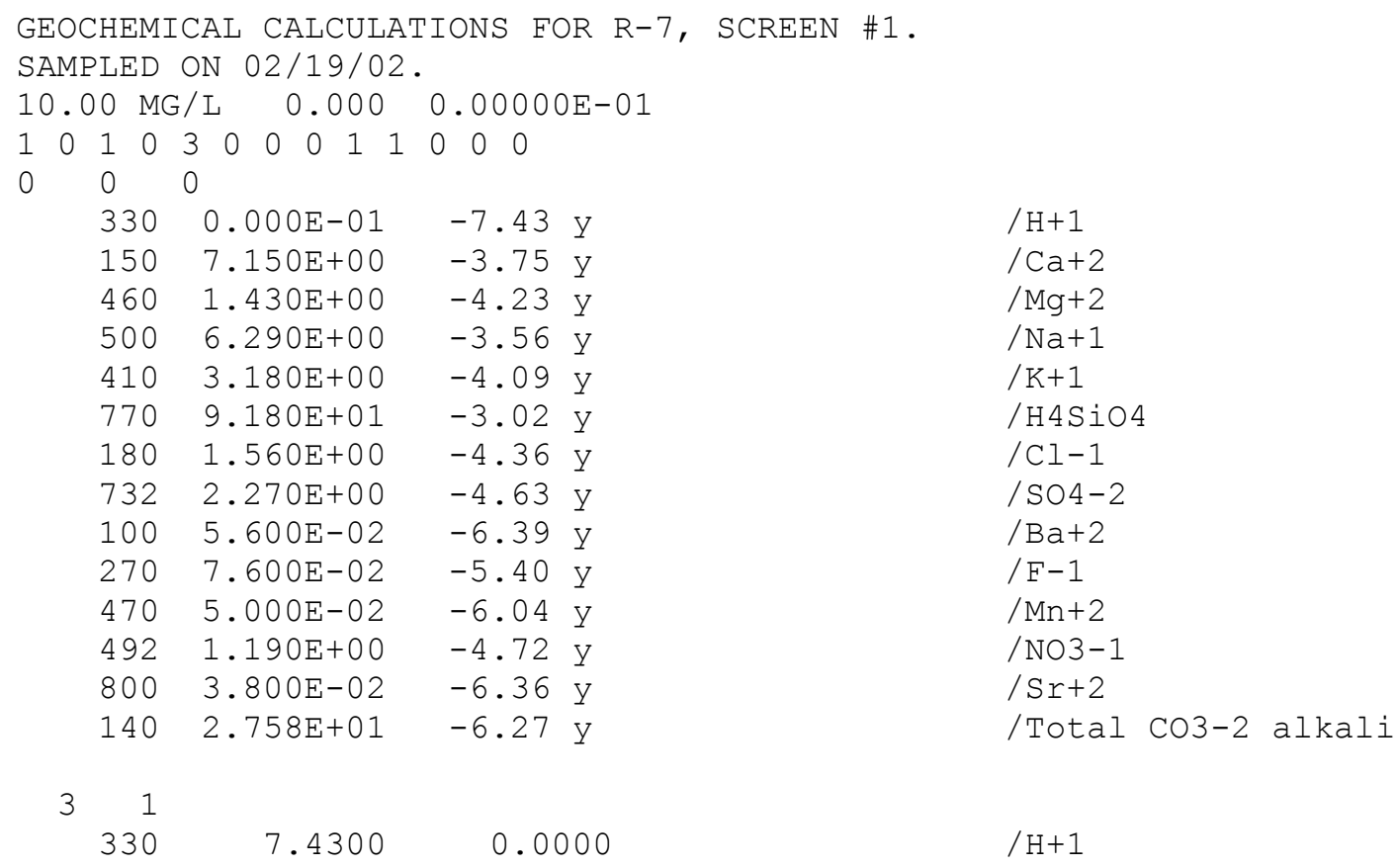




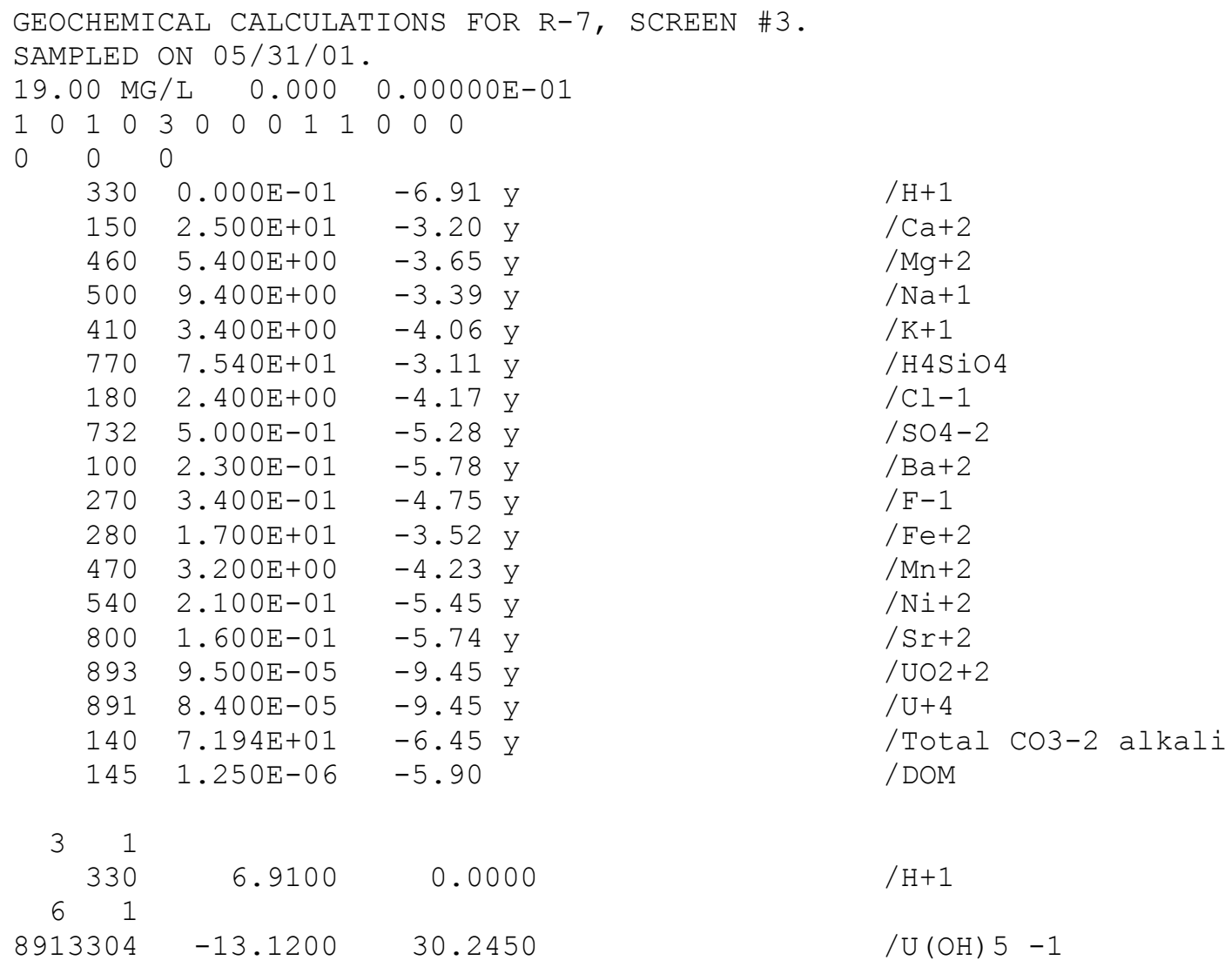


GEOCHEMICAL CALCULATIONS FOR R-7, SCREEN \#3. SAMPLED ON 08/09/01.

$\begin{array}{llll}17.40 \mathrm{MG} / \mathrm{L} \quad 0.000 & 0.00000 \mathrm{E}-01\end{array}$

$\begin{array}{lllllllllllll}1 & 0 & 1 & 0 & 3 & 0 & 0 & 0 & 1 & 1 & 0 & 0 & 0\end{array}$

$0 \quad 0 \quad 0$

$330 \quad 0.000 \mathrm{E}-01-6.81 \mathrm{y}$

$150 \quad 2.200 \mathrm{E}+01-3.26 \mathrm{y}$

$\begin{array}{llll}460 & 5.300 \mathrm{E}+00 & -3.66 \mathrm{y} \\ 500 & 1.000 \mathrm{E}+01 & -3.36 \mathrm{y}\end{array}$

$410 \quad 3.000 \mathrm{E}+00 \quad-4.12 \mathrm{y}$

$770 \quad 7.180 \mathrm{E}+01-3.13 \mathrm{y}$

$180 \quad 2.500 \mathrm{E}+00 \quad-4.15 \mathrm{y}$

$7325.000 \mathrm{E}-01-5.28 \mathrm{y}$

$100 \quad 2.400 \mathrm{E}-01 \quad-5.76 \mathrm{y}$

$270 \quad 4.000 \mathrm{E}-01-4.68 \mathrm{y}$

$280 \quad 1.400 \mathrm{E}+01 \quad-3.60 \mathrm{y}$

$470 \quad 3.400 \mathrm{E}+00 \quad-4.21 \mathrm{y}$

$540 \quad 1.200 \mathrm{E}-01 \quad-5.69 \mathrm{y}$

$800 \quad 1.400 \mathrm{E}-01 \quad-5.80 \mathrm{y}$

$8915.100 \mathrm{E}-05 \quad-9.67 \mathrm{y}$

$893 \quad 5.800 \mathrm{E}-05 \quad-9.67 \mathrm{y}$

$140 \quad 6.595 \mathrm{E}+01-6.61 \mathrm{y}$

$/ \mathrm{H}+1$

$/ \mathrm{Ca}+2$

$/ \mathrm{Mg}+2$

$/ \mathrm{Na}+1$

$/ \mathrm{K}+1$

/ H4SiO4

/ Cl-1

/ $\mathrm{SO} 4-2$

$/ \mathrm{Ba}+2$

$/ \mathrm{F}-1$

$/ \mathrm{Fe}+2$

$/ \mathrm{Mn}+2$

$/ \mathrm{Ni}+2$

$/ \mathrm{Sr}+2$

$/ \mathrm{U}+4$

/ UO2+2

/Total co3-2 alkali

31

330

6.8100

0.0000

$/ \mathrm{H}+1$

891330

$-13.1200$

30.2450

$/ \mathrm{U}(\mathrm{OH}) 5-1$ 


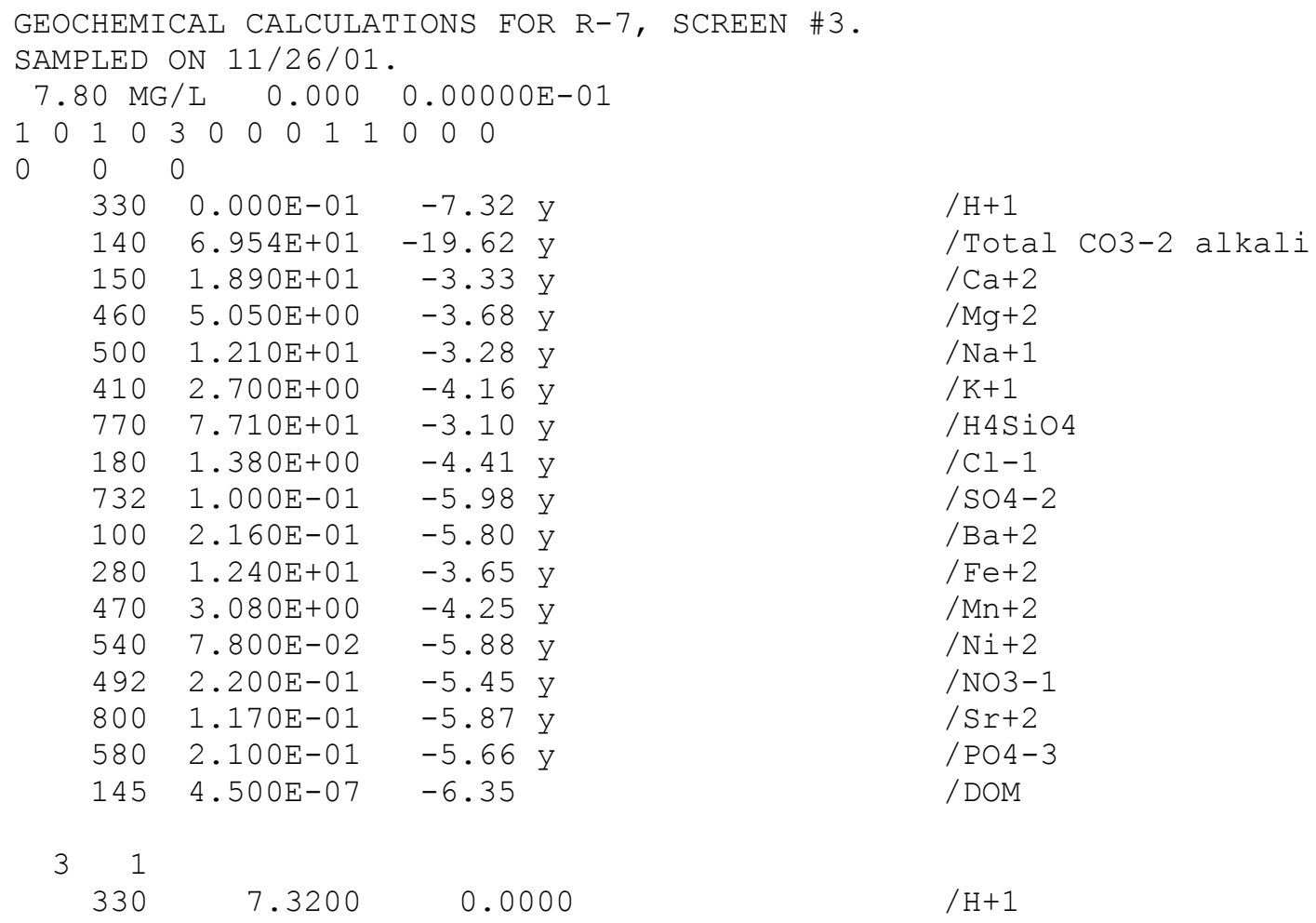




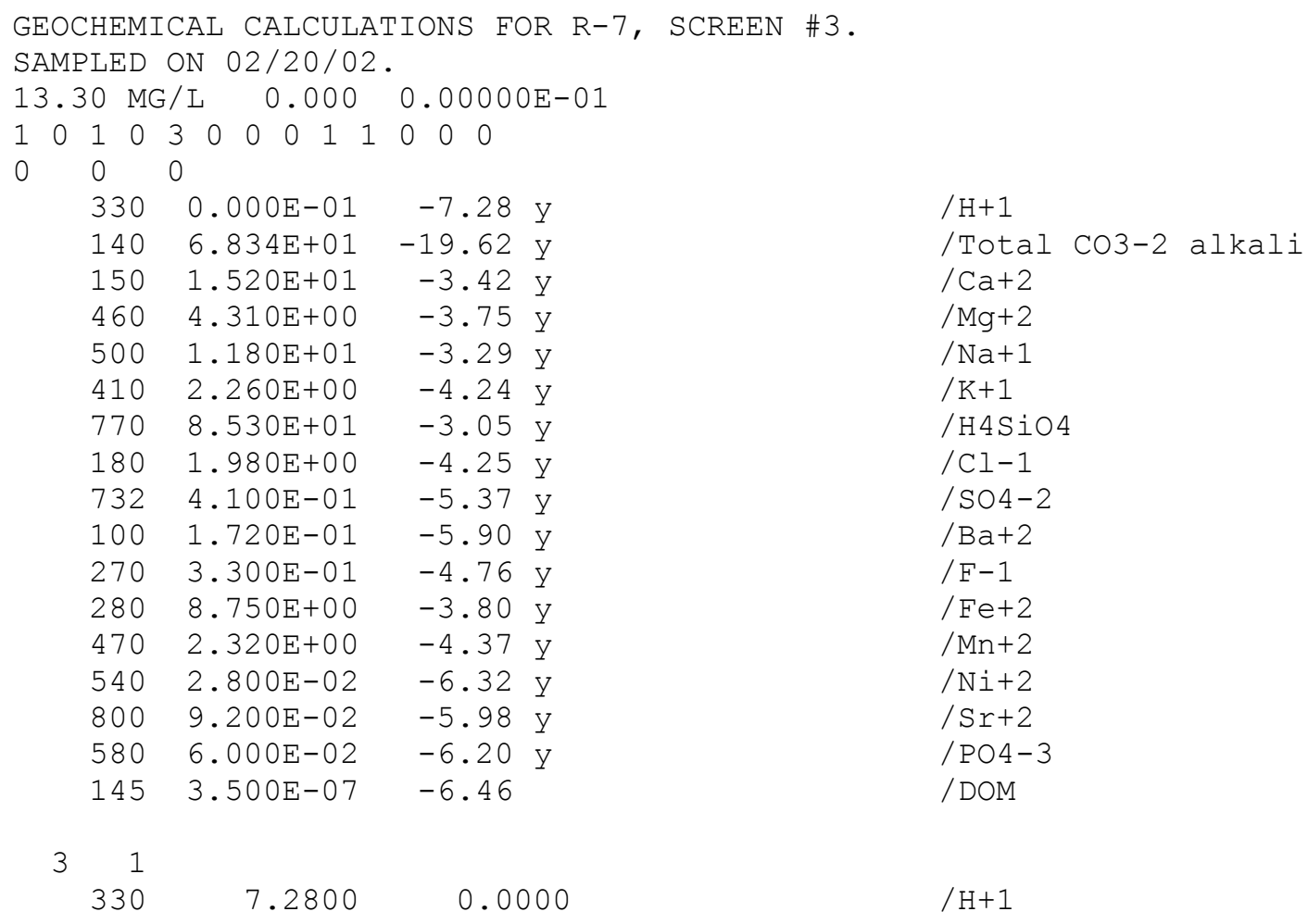


This report has been reproduced directly from the best available copy. It is available electronically on the Web (http://www.doe.gov/bridge).

Copies are available for sale to U.S. Department of Energy employees and contractors from-

Office of Scientific and Technical Information

P.O. Box 62

Oak Ridge, TN 37831

(865) 576-8401

Copies are available for sale to the public from-

National Technical Information Service

U.S. Department of Commerce

5285 Port Royal Road

Springfield, VA 22616

(800) 553-6847 


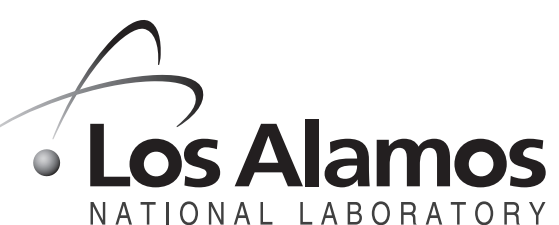

Los Alamos NM 87545 